\title{
Application of Positive Design Principles Towards Improvement of Human Mental Health
}

\author{
Elena Biljanoska-Nakjeva*
}

Faculty of Mechanical Engineering, Industrial Design, Ss. "Cyril and Methodius University" of Skopje, Skopje, Republic of Macedonia

\begin{abstract}
Citation: Biljanoska-Nakjeva E. [Application of Positive Design Principles Towards Improvement of Human Mental Health]. SEE J Archit Des. 2018 Jun 20; 10037. [MSc] http://dx.doi.org/10.3889/seejad.2018.10037

Keywords: Industrial design; Mental health; Pavillio ; Urban equipment; Urban design; Bionics; Nature Modularity; Ergonomy

*Correspondence: Elena Bilijanoska-Nakjeva. Faculty of Mechanical Engineering, Industrial Design, Ss. "Cyril and Methodius University" of Skopje, Skopje, Republic of Macedonia. E-mail: elena_biljanoska@hotmail.com

Received: 04-May-2018; Revised: 10-Jun-2018 Accepted: 15-Jun-2018; Published: 20-Jun-2018

Copyright: ๑ 2018 Elena Biljanoska-Nakjeva. This is an open-access article distributed under the terms of the Creative Commons Attribution License, which permits unrestricted use, distribution, and reproduction in any medium, provided the original author and source are

Competing Interests: The author has declared that no competing interests exis
\end{abstract}

\section{Abstract}

In this master thesis, a research process for obtaining a creative solution which will contribute to solving problems created by the "urban jungle" we live in, and will help for the general improvement of people's mental health is presented. This goal is achieved by a detailed interdisciplinary research and application of modern methods and principles in the field of industrial design. The research allowed a better view of the problem-lack of adequate spaces in the city for productive time spending and increasing positive moods-that needs to be solved, and better defining of the main needs and desires of the target group from which the concepts and ideas emerged. Generally, this research, besides the theoretical analysis of the subject positive design, contains ethnographic research methods like observation of the target group, collecting photo materials, analysis of different situations, informative polls, analysis and systematization of data. In addition, the research is complemented in the field of urban design from aspect of analysis of the urban design principles, design for good mental health, existing ideas of urban solutions around the world and in Macedonia, and also, application of modular systems, ergonomics and inspiration from nature for eco design in urbanism.

As a result of all the research done in this master thesis, an innovative, urban pavilion was designed. Pavilion which would achieve the goal-stress reduction and alleviating the everyday life of residents of modern cities. Also the need for increasing awareness about the significance of positive design in the modern lifestyle was promoted, since design is the main element in all our surroundings that allows possibilities for deep influence in the way we think and feel which means that it can be used as a tool to improve the general wellbeing and society advancement. 


\title{
Примена на принципите на позитивен дизајн врз подобрување на менталното здравје на луѓето
}

\author{
МАГИСТЕРСКИ ТРУД \\ Изработила: Елена Билјаноска - Наќева 706 \\ Ментор: Проф. д-р Софија Сидоренко
}

Постдипломски студии

Индустриски дизајн и маркетинг

Скопје, 2018 
Ментор:

Членови на комисијата:

Дата на одбрана:

Дата на промоција:
Проф. д-р Софија Сидоренко Машински факултет - Скопје Проф. д-р Софија Сидоренко Машински факултет - Скопје

Проф. д-р Татјана Кандикјан Машински факултет - Скопје

Проф. д-р Ристо Ташевски Машински факултет - Скопје 
Елена Билјаноска - Наќева

\section{Примена на принципите на позитивен дизајн врз подобрување на менталното здравје на луѓето}

\section{АПСТРАКТ}

Во овој магистерски труд е презентирано истражување чија крајна цел е да се даде креативно решение на дел од проблемите кои ги наметнува „урбаната џунгла“ во животот на луѓето и кое ќе помогне за подобрување на општото ментално здравје на граѓаните. Оваа цел е постигната преку процесот на интердисциплинарно истражување и примена на современи методи и принципи од областа на индустрискиот дизајн. Деталното истражување овозможи согледување на проблемот - недостаток од соодветни простори во градот за продуктивно минување на времето и зголемување на позитивното расположение - кој треба да се реши, како и дефинирање на главните потреби и барања на луѓето од кои произлегоа концепти и идејни решенија. Генерално, ова истражување, покрај детална теоретска анализа на тема позитивен дизајн, содржи етнографски истражувачки методи меѓу кои доминираат набљудување на таргет групата, собирање на фото материјали, анализа на различни опсервирани ситуации, информативно анкетирање, анализа и систематизација на податоците. Дополнително, извршено е истражување од областа на урбан дизајн од аспект на анализа на неговите принципи, урбан дизајн за добро ментално здравје, постоечки идеи на урбани решенија во светот и Македонија, како и примена на модуларни системи, ергономија и инспирација од природата за еко дизајн во урбанизмот.

Како резултат на целовкупните истражувања во рамките на оваа магистерска работа, е развиен иновативен дизајн на павиљон кој би ја постигнал целта за намалување на стресот и олеснување на секојдневието на жителите во современите градови. Воедно, се промовира потребата за подигање на свеста за значењето на позитивниот дизајн во современиот стил на живеење, бидејќи дизајнот фигурира како главен елемент во целото наше опкружување и нуди можност за длабоко влијаније врз начинот на размислување и чувствување што значи дека истиот може да употреби како алатка за подобрување на општата благосостојба која ќе резултира со напредок на општеството.

Клучни зборови: индустриски дизајн, ментално здравје, павиљон, урбана опрема, урбан дизајн, бионика, природа, модуларност, ергономија 
Elena Biljanoska - Nakjeva

\title{
Application of the positive design principles for improving people's mental health
}

\begin{abstract}
In this master thesis, a research process for obtaining a creative solution which will contribute to solving problems created by the "urban jungle" we live in, and will help for the general improvement of people's mental health is presented. This goal is achieved by a detailed interdisciplinary research and application of modern methods and principles in the field of industrial design. The research allowed a better view of the problem - lack of adequate spaces in the city for productive time spending and increasing positive moods that needs to be solved, and better defining of the main needs and desires of the target group from which the concepts and ideas emerged. Generally, this research, besides the theoretical analysis of the subject positive design, contains etnographic research methods like observation of the target group, collecting photo materials, analysis of different situations, informative polls, analysis and systematization of data. In addition, the research is complemented in the field of urban design from aspect of analysis of the urban design principles, design for good mental health, exsisting ideas of urban solutions around the world and in Macedonia, and also, application of modular systems, ergonomy and inspiration from nature for eco design in urbanism.
\end{abstract}

As a result of all the research done in this master thesis, an innovative, urban pavillion was designed. Pavillion which would achieve the goal - stress reduction and alleviating the everyday life of residents of modern cities. Also, the need for increasing awareness about the significance of positive design in the modern lifestyle was promoted, since design is the main element in all our surroundings that allows possibilities for deep influence in the way we think and feel which means that it can be used as a tool to improve the general wellbeing and society advancement.

Key words: industrial design, mental health, pavillion, urban equipment, urban design, bionics, nature, modularity, ergonomy 


\section{СОДРЖИНА}

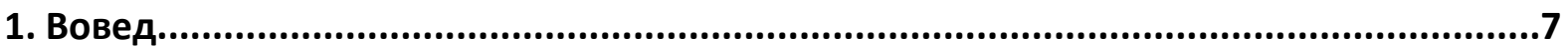

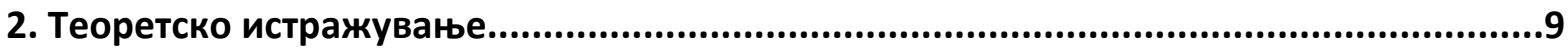

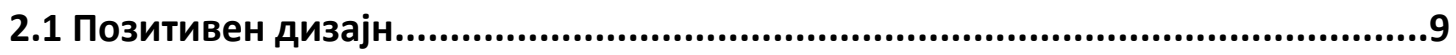

2.1.1 Психологија на дизајнирање за среќа............................................9

2.1.2 Теорија на „протек“ ..................................................................10

2.1.3 Рамка на позитивен дизајн.....................................................12

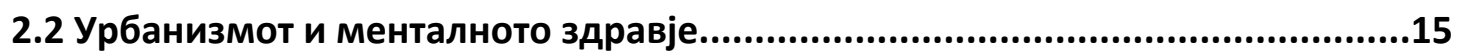

2.2.1 Како животот во градовите влијае врз менталното здравје..........15

2.2.2 Како менталното здравје влијае врз продуктивноста, а со тоа директно и врз напредокот на градовите и општеството............................................17

2.2.3 Како урбаниот дизајн може да помогне врз подобрување на менталното здравје и зголемување на позитивното расположение...........................20

2.2.3.1 Зелени површини.........................................................21

2.2.3.2 Активни зони..............................................................25

2.2.3.3 Про-социјални места .......................................................27

2.2.3.4 Безбедни места............................................................29

2.2.4 Заклучок од истражувањето..........................................................30

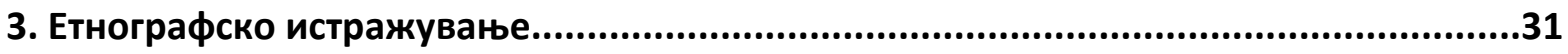

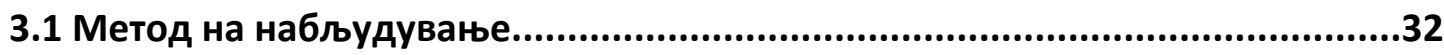

3.1.1 Заклучок од метод на набљудување............................................35

3.2 Метод на испитување (анкетен прашалник).............................................36

3.2.1 Заклучок од анализа на анкетен прашалник.................................47

4. Дефинирање на дизајнерски проблем за примена на прочуените принципи........48

4.1 Согледување на потреба - идеја за производ...........................................48

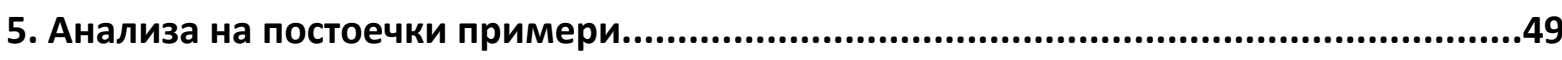

5.1 Урбанизам низ светот...............................................................................49 


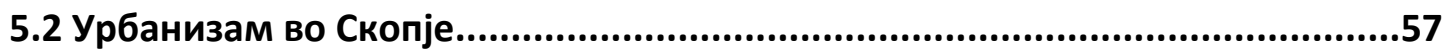

5.3 Заклучок од анализа на пазарот...........................................................64

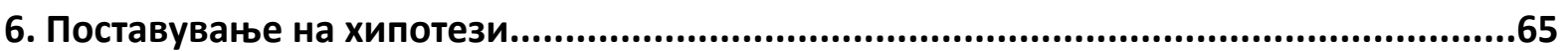

7. Дефинирање на дизајнерски цели................................................................66

7.1 Конечни цели за дизајн на павиљон.......................................................68

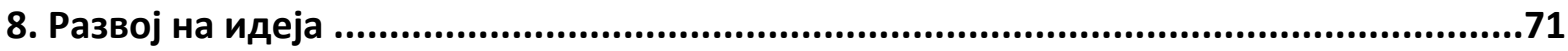

8.1 Модуларни системи...................................................................................71

8.2 Адаптација на околината..........................................................................72

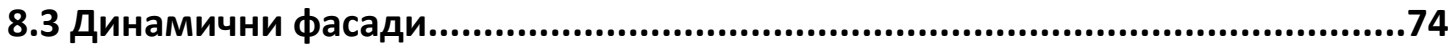

8.3.1 Примери за примена на динамични фасади.................................75

8.4 Еколошко производство на електрична енергија........................................78

8.5 Акумулација на вода...................................................................................78

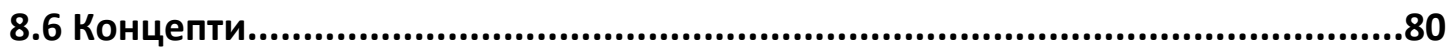

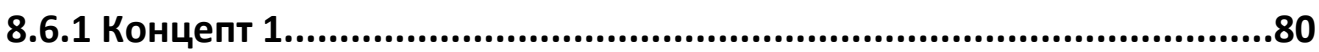

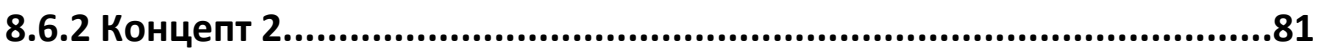

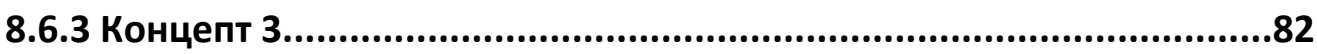

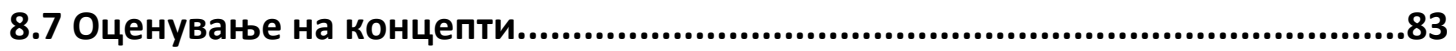

9. Презентација на избраното идејно решение.........................................................86

9.1 ЗД модел, објаснување на детали .......................................................86

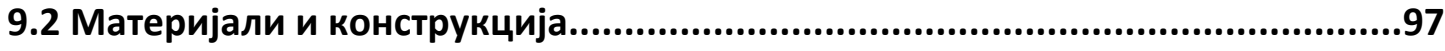

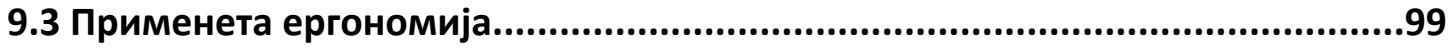

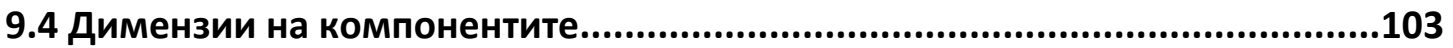

9.5 Психологија на бои - образложување на изборот на бои...........................106

10. Евалуација на дизајнот...................................................................................109

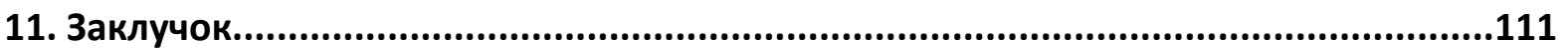

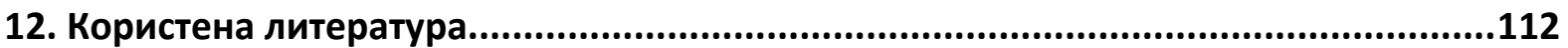




\section{1. ВОВЕД}

Главниот фокус во дизајнот општо, а најмногу во индустрискиот дизајн, е покрај задоволување на основните функционални барања и потреби на таргет групата, истовремено да се поттикнат позитивни реакции и емоции кај нив. Ова најчесто, од маркетиншки аспект, се поврзува со интересот на компаниите да постигнат вистинска, мултибренд лојалност кај купувачите која резултира со профит и раст на приходите на компанијата, како и добра „word-of-mouth“ комуникација што значи стабилен пораст на интересот за брендот.

Но, во овој магистерски труд акцентот е ставен на дизајнирање за позитивни емоции од аспект на подобрување на начинот на живот на луѓето и позитивно влијаније врз нивното ментално здравје. Во последно време, бројни фактори од секојдневието на луѓето меѓу кои: зголемените работни задачи и работни часови, животот во градовите, нееднаквост меѓу слоевите, климатски промени, нарушување на природата итн., започнаа да влијаат врз нагло зголемување на стресот што резултира со блокада на квалитетот на работните и социјалните активности, како и појава на различни степени на нарушувања на менталното здравје. Поради тоа, се почесто се наметнува прашањето - како да им се помогне на луѓето да ги избегнат, или во најмала рака да ги намалат, негативните влијанија кои ги носат модерните општества, на кои начини може да се помогне да го зголемат квалитетот на живот и општото чувство на позитивност и среќа.

Ова е исклучително значајно поради тоа што среќните луѓе придонесуваат повеќе за општеството, попродуктивни се на работните места, покреативни, полесно се справуваат со стрес и траума и се подобри лидери. Тие имаат повеќе пријателства, подолготрајни бракови, посилна социјална поддршка, побогати социјални интеракции, поактвни се, поенергични, посамоуверени, имаат подобра самоконтрола, покажуваат повеќе интерес за укажување помош кон другите, имаат подобро физичко здравје, па дури и подолг живот.

Од овој аспект дизајнерите носат подлабока одговорност, тие мораат да се впуштат во сериозно истражување на емотивната и ментална врска помеѓу еден корисник и дизајнираниот произовод со цел дизајнираните производи да влијаат позитивно врз корисниците, односно, покрај тоа што производите треба да задоволуваат одредена функција и да се убави, тие треба да влијаат врз зголемување на позитивниот став кај оние кои го употребуваат. Од ова имаат бенефит и луѓето и општествената средина.

Денес, кога повеќе од 50\% од вкупната глобална популација живее во градовите и е под влијаније на стресното секојдневие кое го носи животот во град, урбаниот дизајн има возбудлив потенцијал во однос на позитивно влијание врз популацијата. 
Во оваа магистерска работа, детално се проучени негативните влијанија врз секојдневието на возрасните, вработени жители на градот, главните причинители на стрес, негативно расположение, непродуктивност и депресивни мисли. Покрај ова, земени се во предвид општите размислувања на луѓето преку анализа на селектирана категорија испитаници во врска со тоа што чувствуваат дека недостасува за подобрување на нивното ментално здравје. Исто така, истражени се најновите достигнувања од областа на интегрираното урбано планирање во големите градови од аспект на позитивен дизајн. Збирните резултати од сите истражувања се применети за дизајн на урбан павиљон кој претставува локација што е единство на основните елементи на урбан дизајн за позитивно расположение - поврзаност со природата, безбедност, социјалност и активност. Дополнително, со цел да биде максимално успешен во својата функција, дизајнот се темели на принципите на модуларност, бионика, екологија и ергономија.

Цел на овој магистерски труд е да се нагласи дека и покрај тоа што има постојан раст на иновативни производи кои ја подобруваат материјалната состојба на луѓето истите не ја подобруваат емотивната состојба. Дизајнерите при креирање на нов производ треба да истражуваат методи со кои тој производ, покрај тоа што ќе им побуди позитивни емоции, ќе им помогне на корисниците да се однесуваат на определени начини со кои постепено ќе го подобруваат нивното психичко здравје и ќе ја зголемат нивната среќа.

Главната цел е да се даде креативно решение кое ќе придонесе за решавање на проблемите кои ги наметнува „урбаната џунгла“ во животот на луѓето, да се понуди концепт на простор/објект кој би можел да биде прифатен од општините за поставување низ повеќе локации во градот и од компаниите кои би го поставиле до главните објекти за употреба од страна на нивните вработени. Тоа би бил објект кој би претставувал делумно надоместување за недостатокот на слободно време и можности за релаксација и кој би помогнал за стимулирање на креативноста и позитивното расположение.

Финална цел е креираниот објект да претставува единство на ентериерот со екстериерот и модерен урбанистички концепт кој покрај тоа што ќе биде удобен и ергономски, дизајниран според принципите за побудување среќни емоции кај луѓето, истовремено ќе биде целосно еколошки, преку примена на еколошки функции и природни и обновливи материјали во конструкцијата. 


\section{2. ТЕОРЕТСКО ИСТРАЖУВАЊЕ}

\section{1 ПОЗИТИВЕН ДИЗАЈН}

\subsection{1 Психологија на дизајнирање за среќа}

Главниот фокус во дизајнот општо, а најмногу во индустрискиот дизајн, е да се поттикнат позитивни емоции и реакции покрај основното задоволување на потребите на таргет групата. Поради намалувањето на слободното време, зголемување на растот на нестабилната глобална економија, порастот на нееднаквостите меѓу слоевите, климатските промени, уништување на природата и други бројни фактори [32] нивото на стрес се зголемува. Последните истражувања покажуваат дека луѓето не мислат дека нивниот живот се подобрува. Од овие причини, во последните две декади дизајнот се повеќе го следи патот на емоциите. За да бидат успешни дизајнерските решенија и да помогнат во зголемувањето на квалитетот на животот, дизајнерите мораат да се впуштат во сериозно истражување на емотивната и менталната врска помеѓу еден корисник и дизајнираниот производ. Емоцијата во целиот процес на дизајнирање треба да ги содржи следните три компоненти: дизајнерот, дизајнерскиот исход и корисникот. Само солидно разбирање на интерактивните односи помеѓу овие три компоненти може да резултира со успешен производ и среќни корисници.

Зошто би требало да дизајнираме за позитивни емоции и среќа?

Среќните луѓе даваат позитивен придонес во општеството, попродуктивни се на работните места, покреативни, полесно се справуваат со стрес и траума и се подобри лидери. [1] Дополнително, среќните луѓе имаат повеќе пријателства, подолготрајни бракови, посилна социјална поддршка, побогати социјални интеракции, поактивни се, поенергични, посамоуверени, имаат подобра самоконтрола, покажуваат повеќе интерес за укажување помош кон другите, имаат подобро физичко здравје (посилен имунитет, намалено ниво на стрес и болка), па дури и подолг живот.

Од педесеттите години на минатиот век до сега, материјалната состојба на луѓето низ светот се удвоила. Денес постои огромен избор на многу добри производи, но и покрај тоа, емоционалната состојба на луѓето, наместо да биде подобрена, останува непроменета. Тоа значи дека дизајнот на сите тие одлични производи не влијаел многу врз зголемување на среќата на луѓето. Во секојдневието сме опкружени со производи кои прават да се чувствуваме добро, но генерално не не прават посреќни. Поради тоа, пристапот при дизајнирање за долгорочна среќа и благосостојба треба да биде многу поразличен од пристапот за дизајнирање заради краткотрајни емоции. Нашето опкружување не ја дефинира нашата среќа, туку начинот на кој ние се однесуваме во тоа опкружување е решавачкиот фактор за тоа дали ќе бидеме среќни или не [2]. Имајќи го ова во предвид, дизајнерите при креирање на нов производ треба да истражуваат методи со кои тој производ освен што ќе им побуди позитивни емоции, ќе им помогне на корисниците да се однесуваат на определени начини со кои постепено ќе го подобруваат нивното психичко здравје и ќе ја зголемат нивната среќа.

Истражувачот Мартин Селингман [3] користи една едноставна равенка со која опишува од каде доаѓа среќата на луѓето: 


$$
\mathrm{H}=\mathrm{S}+\mathrm{C}+\mathrm{V}
$$

Каде „Н“ е нивото на среќa и таa е збир од: „S“ - утврдениот распон на среќa (среќa со која сме родени - билошки и генетски фактори кои го дефинираат нашиот карактер), „C“ - моменталните околности во животот, и „V“ - факторите кои се во нашата доброволна контрола. Ова значи дека дел од нашата среќа ни е генетички предодредена, дел е под влијание од сите услови кои моментално не опкружуваат (местото каде живееме, културните, политичките фактори, моментални случувања и сл.), а дел од среќата можеме своеволно да ја контролираме. Овие прикажани во проценти се презентирани на следниот графикон [1]:

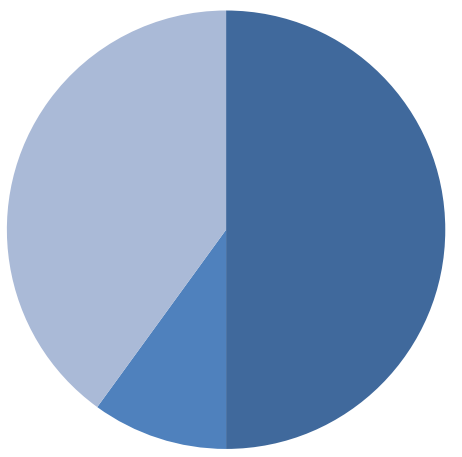

\author{
- 50\% - биолошки и \\ генетски фактори \\ 10\% - надворешни \\ околности \\ 40\% - акции и \\ размислувања
}

Граф.2.1.1-1 Графички приказ на варијабилите кои го оформуваат нивото на среќа, според Мартин Селингман.

Ова значи дека дури 40\% од нашата среќa е менлива и врз неа може да се влијае преку намерно ангажирање во различни активности. Ова е областа на интерес за дизајнерите кои со своите производи би требало да им помогнат на корисниците да се впуштаат во позитивни активности кои ќе ја подобрат нивната емотивна и психичка состојба.

Постои широк распон активности, чие практикување може да влијае врз оние 40\% кои се во наша доброволна контрола, меѓу кои се: физичка активност, грижа за здравјето, вежбање на техники за релаксација и за оддржување на позитивните мисли, социјални интеракции, добротворни дела, како и пронаоѓање на сопствениот „протек“.

\title{
2.1.2 Теорија на „протек“
}

Кога активно сме инволвирани во обидот да постигнеме некоја цел или ангажирани со активност која ни претставува предизвик, но е соодветна на нашите вештини, ние искусуваме една среќна состојба која Михали Цсиксентмихали ја нарекол „протек“ [4]. Во состојбата на „протек“, акцијата тече според внатрешна логика за која не треба свесна интервенција од страна на авторот, туку тој искусува протек од еден момент до следниот, при што ги контролира сопствените акции без да прави дистинкција помеѓу себе и средината, помеѓу стимулот и одговорот, помеѓу минатото, сегашноста и иднината - односно, „протекот“ е еден вид на состојба на екстаза, целосен ангажман и инволвираност во нешто што ни претставува задоволство (Граф.2.1.2-1). Во истражувањата, Цсиксентмихали ги вклучил уметниците кои целосно се внесувале во своите дела се додека не ги завршат, занемарувајќи ги гладот, недостатокот на сон и останатите неудобности, а веднаш по завршување на сликата 
интересот за неа им се намалувал. Концептот на „протек“ ги има следниве 6 главни карактеристики:

1) Интезивна и фокусирана концентрација на она што се прави во моментот

2) Спојување на акцијата и свесноста

3) Губење на рефлексивната самосвест

4) Чувство дека може да се контролираат акциите - чувство дека поединецот може да се справи со ситуацијата затоа што знае како да одговори на што и да се случи следно

5) Изобличување на временското искуство - чувство дека времето поминало побргу

6) Чувство дека активноста суштински наградува, односно крајната цел е праведен изговор за процесот

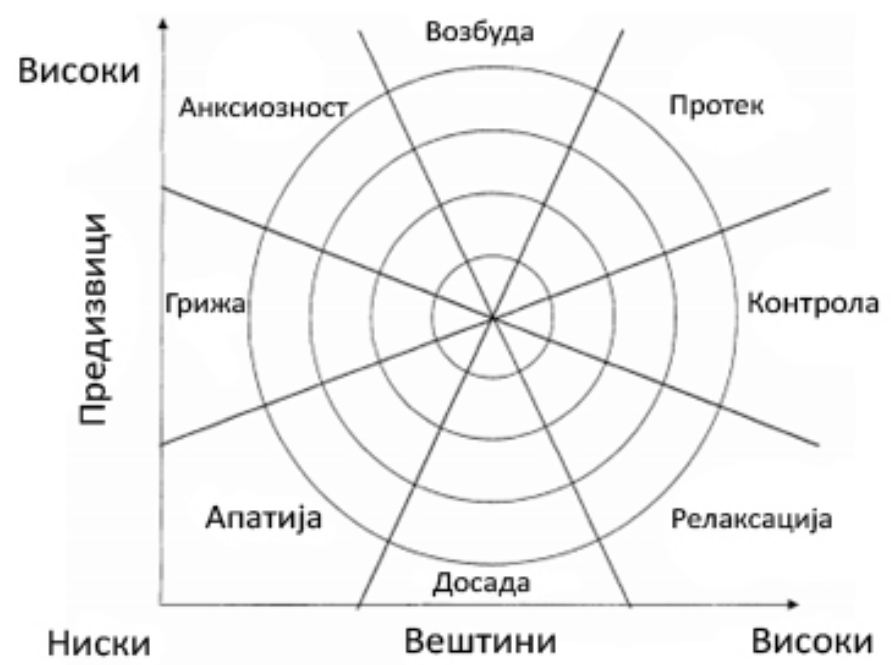

Граф.2.1.2-1 Графички приказ на теоријата на „протек“, според Михали Цсиксентмихали.

Важно е предизвикот да е на високо ниво, но да соодветствува на нивото на вештини на индивидуата. „Протек“ се искусува кога предизвиците и вештините се над средните нивоа на предизвици и вештни за таа индивидуа, во спротивно (под овие нивоа) се искусува апатија и досада [5]. Кога е во состојба на „протек“ индивидуата го постигнува својот целосен капацитет, а тоа влијае врз зголемување на општото чувство на среќа, поради што ваквиот ангажман треба да се поттикнува.

Во таа насока, иницијативите за позитивен дизајн намерно настојуваат да ја зголемат субјективната благосостојба на луѓето и со тоа да го зголемат истрајното чувство на вредност на нивните животи, нивниот развој, „цветање“, постигнување „протек“ и достигнување на сопствениот максимален потенцијал. 


\subsection{3 Рамка на позитивен дизајн}

Питер Десмет и Ана Полмаер, во нивното дело „Позитивен дизајн: вовед во дизајн за субјективната благосостојба“ [6] опишуваат дека рамката на позитивен дизајн вклучува 3 главни компоненти на субјективната благосостојба: дизајн за задоволство (искусување позитивен ефект), дизајн за лично значење (следење на личните цели) и дизајн за доблест (станување на морално добра личност) (Сл.2.1.3-1).

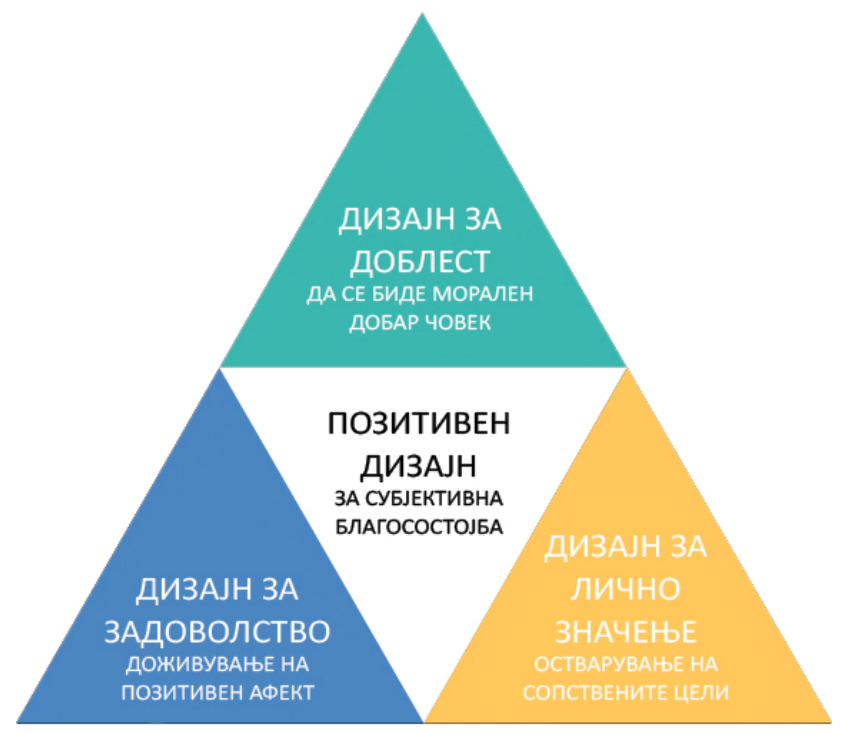

Сл.2.1.3-1 Визуелен, пирамидален приказ на главните компоненти на рамката на позитивен дизајн.

Секоја од компонентите независно ја стимулира благосостојбата на субјектот, а позитивниот дизајн лежи во центарот, каде сите три компоненти се сечат. Овој пресек е местото каде луѓето „цветаат“. „Цветањето“ е оптимално човечко функционирање и живеење до целосниот потенцијал. Според Селингман [3] за да „процвета“, покрај поседувањето позитивни емоции, индивидуата мора да има и чувство на значење, ангажман, интерес и цел во животот. Според тоа, дизајнот треба да оди подалеку од креирање само на краткотрајно задоволство иако задоволството е есенцијална компонента на благосостојбата. Идејата е дека, иако дизајнирањето според која било од трите компоненти е во добра насока за постигнување на благосостојба кај корисниците, позитивниот дизајн треба да ги има во предвид сите три компоненти. Иако, главниот акцент може да биде само на една од трите компоненти, дизајнот не смее да има негативен ефект врз останатите две, туку треба да ги има во предвид. На пример, доколку дизајнот не стимулира доблесно однесување, истиот не треба да стимулира не-доблесно однесување додека е фокусиран на една или две други компоненти.

Првиот елемент на триаголникот, е дизајн за задоволство - тоа е среќата која доаѓа од уживање во моментот, односно збирот на моменталните задоволства за индивидуата. Фокусот е во сегашноста - чувство на релаксираност, на забава, на ослободеност од проблеми и сл. Производите може да побудуваат позитивни чувства, да го максимизираат задоволството и комодитетот или, пак, самите по себе да претставуваат извор на задоволство со начинот на кој се изработени, материјалите од кои се изработени и сл. Питер Десмет [7] во своите истражувања издвоил 25 позитивни емоции кои луѓето ги доживуваат при интеракција со производи и 
причинителите за нивното појавување (Таб.2.1.3-1). Познавањето на овие емоции е важно, поради тоа што секоја емоција поттикнува како реакција одреден начин на однесување, на пример фасцинацијата поттикнува желба за истражување, радоста поттикнува игривост и тоа не само физичка и социјална игра, туку и интелектуална, уметничка и сл. Ова значи дека за дизајнерите е важно познавањето на емоциите и причинителите за нивната појава како и познавањето на реакциите кои ќе произлезат како резултат на тие емоции. На овој начин може однапред да се избере посакуваниот емотивен спектар и дизајнот да се води во таа насока.

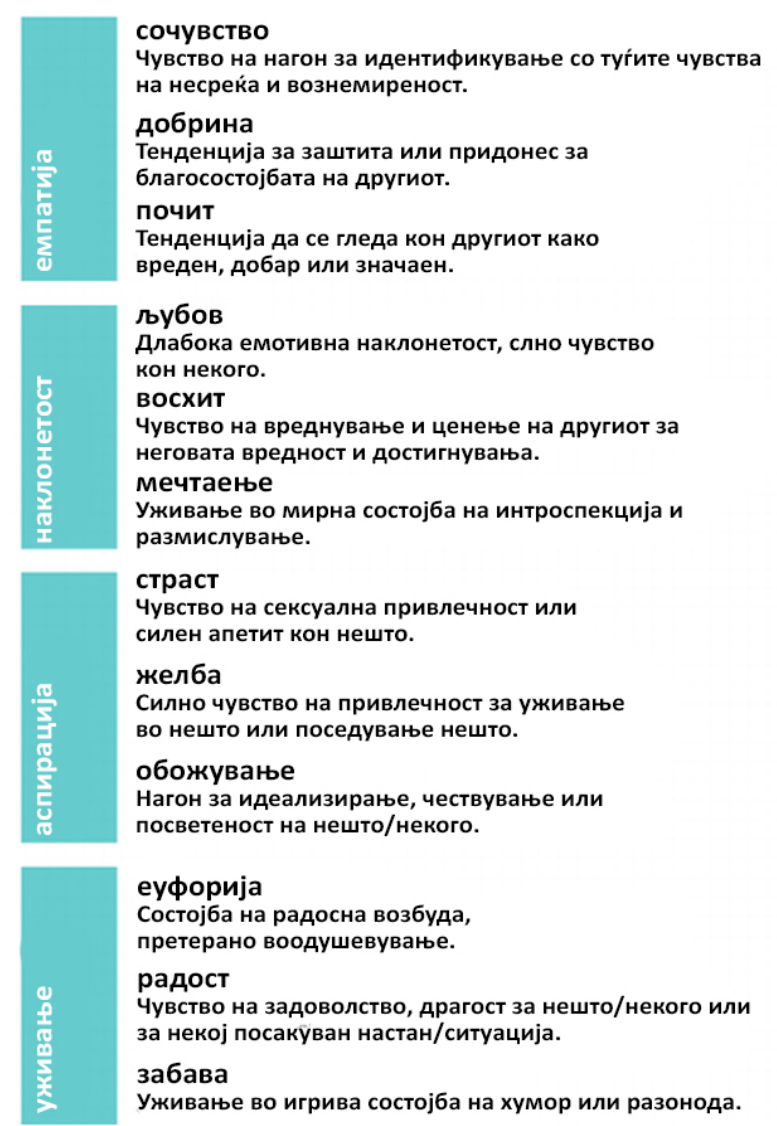

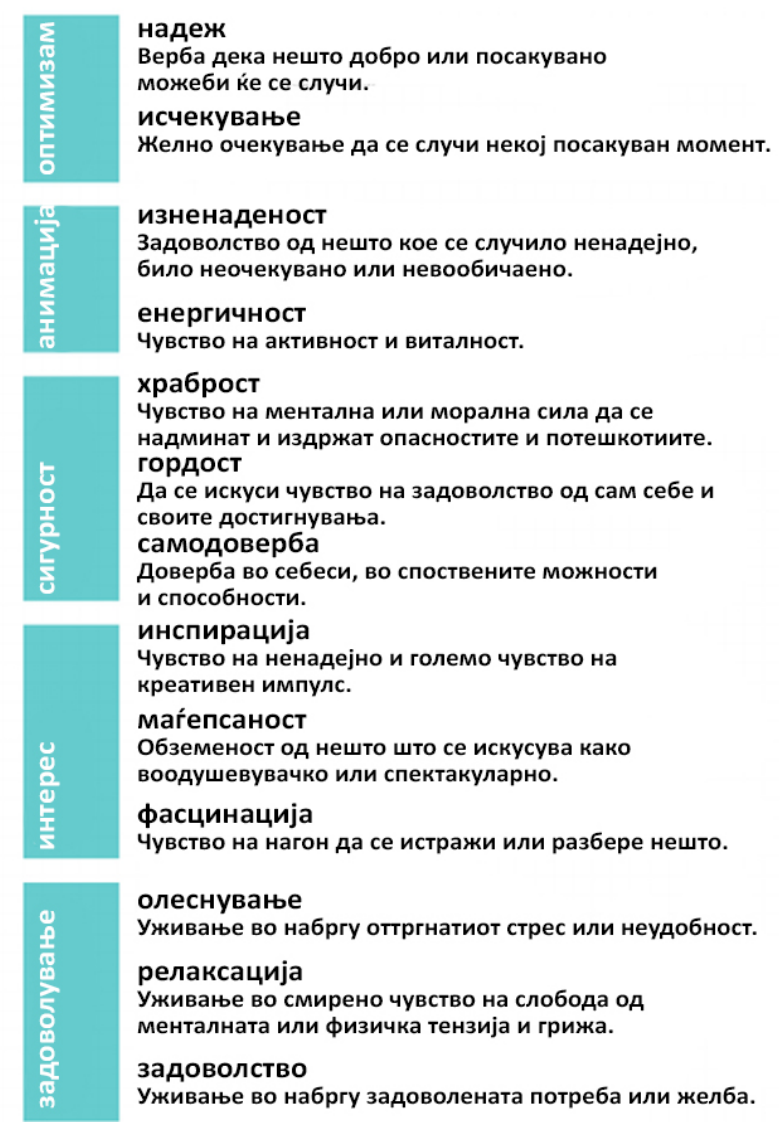

Таб.2.1.3-1 Табеларен приказ на 25 позитивни емоции кои луѓето ги доживуваат при интеракција со производи, според Питер Десмет.

Вториот елемент на триаголникот, е дизајн за лично значење кој се занимава со персоналното значење, грижи, цели и аспирации. Овде фокусот не е на каткотрајно побудување на емоции, туку, дизајнот треба да претставува инструмент за индивидуите да ги постигнат своите цели и да достигнат нешто со што ќе се гордеат и ќе додаде вредност на нивната личност. На пример, еден пар патики може да му помогне на спортистот да ги усоврши своите атлетски вештини, соодветниот алат може да му помогне на таткото да изгради куќарка на дрво за својот син итн.

Третиот елемент на триаголникот, е дизајнот за доблест и ова е најкомплексниот елемент бидејќи перцепцијата за тоа што е добро, а што лошо е доста субјективна и варира кај сите личности. Доблеста е идеализирана човечка вредност која може да се негува на повеќе начини и е базирана на еден идеален начин на однесување, одличност и перфекција кон која индивидуите треба да се стремат со 
цел да живеат доблесен живот. Со цел да усвои систематска класификација и мерливост на пошироко вреднуваните позитивни карактеристики, Мартин Селингман [8] ги истражувал сите најзастапени религии и филозофски традиции и дефинирал 6 доблести кои се заеднички за скоро сите култури и 24 силни карактерни особини од кои овие доблести се оформени (Таб.2.1.3-1).
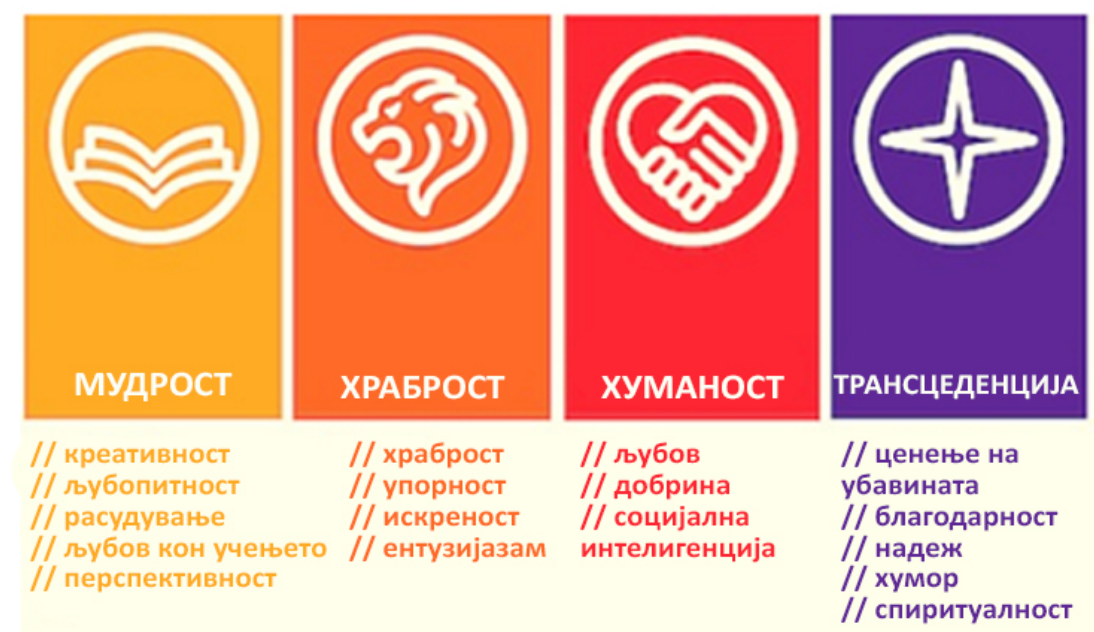

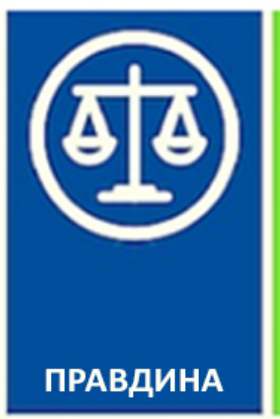

// тимска работа // праведност

// лидерство

// спиритуалност

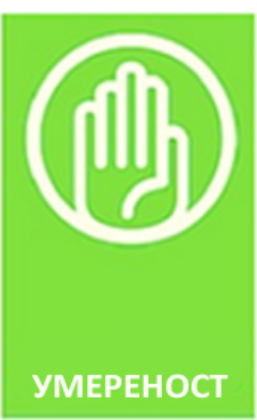

// простување

// скромност

// внимателност // самоконтрола

Таб.2.1.3-2 Табеларен приказ на 24 силни карактерни особини кои ги оформуваат 6-те главни доблести, според Мартин Селингман.

Дизајнираните производи би требало да ги стимулираат корисниците да се однесуваат доблесно. На пример, користењето на електричен автомобил и помага на индивидуата да придонесе за намалување на загадувањето и намалување на трошењето на необновливи енергетски ресурси.

Доналд Норман, во својата книга „Емоционален дизајн“[24] исто така дефинира 3 нивоа на дизајн:

- Висцералниот (визуелен) дизајн се однесува на појавата, се она што го восприемаме преку нашите сетила.

- Дизајнот на однесување има врска со задоволството и ефективноста на употреба на производите.

- Рефлективниот дизајн ја разгледува рационализацијата на еден производ.

Овие 3 нивоа се директно поврзани со претходно споменатите елементи на триаголникот.

Во денешното динамично општество мисија на дизајнерите треба да биде дизајнирање за благосостојба, за „протек“ и „цветање“ на луѓето, тие треба со производите и услугите да влијаат врз секојдневието на корисниците, да влијаат врз оние $40 \%$ среќa кои се менливи и да го подобрат нивното ментално здравје со цел истите да станат попродуктивни на своите работни места, поуспешни во социјалните интеракции и подобри двигатели на општеството во нагорна линија. 


\section{2 УРБАНИЗМОТ И МЕНТАЛНОТО ЗДРАВЈЕ}

\subsection{1 Како животот во градовите влијае врз менталното здравје}

“Менталното здравје е благосостојба во која индивидуата го согледува својот потенцијал, може да се справи со нормалните стресови кои ги носи животот, може да работи продуктивно и плодно, и во можност е да придонесе за општеството."

Светска организација за здравје

Менталното здравје е клучно за општото здравје, благосостојбата и позитивното размислување. Физичките и социјалните средини на урбаниот живот може да придонесат позитивно, но и негативно на менталното здравје на луѓето. Градовите се поврзуваат со почести случаи на проблеми со менталното здравје во споредба со руралните средини: 40\% повисок ризик од депресија, 20\% повеќе анксиозност, дуплиран ризик од шизофренија, зголемени чувства на осаменост, изолација и стрес.

Повеќе од половина од вкупната глобална популација моментално живее во градовите, со постојано растечки тренд за урбанизација. Живеењето во градовите е врзано со зголемена густина на население, сообраќаен метеж, голема загаденост и останати проблеми што ја прави урбанизацијата една од главните промени врзани со здравјето на човештвото. Денес, повеќе од 50\% од глобалната популација живее во градовите, а до 2050 година се очекува дека овој процент ќе се зголеми до 70\% [9]. Со растењето на урбанизацијата, се повеќе луѓе се изложени на фактори кои придонесуваат за зголемување на стресот што има негативно влијание врз менталното здравје, а овие фактори може да потекнуваат од:

- Урбаната социјална средина

$>$ Концентрација на низок социо-економски статус (нивоа на образование, приходи)

$>$ Низок општествен капитал (социјална поддршка, ефикасност)

$>$ Социјална сегрегација (малцински статус, членство во етнички групи)

- Урбаната физичка средина

$>$ Поголема загаденост (на воздух, вода)

$>$ Бучава (сообраќај)

$>$ Урбан дизајн (високи згради кои може да се перцепираат како угнетувачки, преголема густина на објекти)

$>$ Останати физички закани (несреќи, насилство)

Од друга страна, градовите нудат подобра здравствена грижа, вработување и образование. Токму од оваа причина е потребно добро разбирање на односот на интеракцијата помеѓу градот и менталното здравје. 
Истражувањата [10] покажуваат дека ризикот од некои поголеми ментални болести генерално е поголем во градовите отколку во руралните средини. Менталните нарушувања поврзани со анксиозност како пост-трауматски стрес, вознемиреност, лутина и параноја, се почести во урбаните средини отколку во руралните во држави низ Латинска Америка и Азија кои биле предмет на истражувањето. Истото било потврдено и за психотични нарушувувања како шизофренија, во Кина и Германија. Во едно данско истражување е утврдено дека ризикот од шизофренија е повеќе од двојно поголем за поединци кои ги минале првите 15 години во голем град, наспрема оние кои израснале во рурални средини. Слично, нарушувања во расположението се покажале почести во големите градови во Германија. Нарушувања на (интернет) зависност (на пример зависност од онлајн игри) биле утврдени кај голем дел од младите дипломирани французи кои живеат сами во урбаните предели на Франција.

Генерално, постојат 3 главни причини поради кои луѓето во градовите имаат повеќе проблеми со менталното здравје [33]:

1) Претходно-постоечки фактори на ризик: Многу луѓе се селат во градовите во потрага по подобра услуга, економски и социјални можности, и дистанца од минати негативни искуства. Но, стресот со кој таа популација се соочува при започнување на живот во град лесно може да почне да влијае врз расположението и да предизвика благо или силно ментално нарушување.

2) Социјални фактори: Луѓето со претходно-постоечки фактори на ризик, особено сиромаштија и статус на малцинство, често се среќаваат со негативни разлики во градовите. На пример, може да се случи физичка и психолошка сегрегација во маала за кои е карактеристична сиромаштијата и социјалните предизвици, а тоа да резултира со чувство на неправда и безнадежност, соочување со предрасуди и дискриминација што може да влијае врз менталното здравје.

3) Фактори на животна средина: Урбаната средина влијае врз луѓето на 2 клучни начини: зголемување на стимулациите и отстранување на заштитните фактори.

Преоптоварување: Луѓето кои живеат во градовите искусуваат зголемено ниво на надворешно стимулирање, односно густина, гужви, бучава, мириси, глетки, разочарување, загадување и интензитет на други нешта. Секој дел на урбаната средина е дизајниран да пренесува пораки и да има значење. Овие стимулатори предизвикуваат акција и мисла на латентно ниво на свесност и стануваат помоќни како што се појавува неспособност за справување со нив. Поради ова се јавува чувство на преоптоварување (зголемување на основните телесни нивоа на возбуда, стрес и подготвеност), но, исто така, се јавува потребата за ослободување (тивки, приватни места) и со текот на времето оваа потреба може да еволвира во социјална изолација поврзана со депресија и анксиозност.

Намалување на заштитните фактори: Луѓето кои живеат во градовите може да се чувствуваат како да имаат помал пристап до факторите кои се добри 
за менталното здравје, споредено со оние кои живеат во руралните области. На пример, може да имаат намален пристап до природни средини, помали можности да интегрираат физичка активност како дел од секојдневните рутини, како и намалено време за одмор затоа што времето поминато на работа и движејќи се низ градот е зголемено. Луѓето може да се чувствуваат небезбедно, без приватност, без доволно сон, заради факторите како гужва, светлина, бучава и стрес. Дополнително, миграцијата од рурална средина во град често значи дека се напуштаат силните социјални мрежи на пријатели и фамилија, а потребно е доста време за да се развијат слични социјални врски кои претставуваат поддршка поради тоа што урбаните жители не сакаат да се вклучуваат во социјални интеракции со цел да избегнат дополнителни обврски, преоптоварување, поради грижа за безбедноста и сл. Како што овие фактори на поддршка се губат, луѓето стануваат подлежни на намалување на менталното здравје.

\subsection{2 Како менталното здравје влијае врз продуктивноста, а со со тоа} директно и врз напредокот на градовите и опитеството

Доброто ментално здравје значи дека жителите на едно општество се среќни, просперитетни, значи дека тие се подготвени да придонесат за неговиот напредок преку остварување на сопствениот потенцијал, справување со стресот и работење продуктивно и креативно.

Во современото западно општество, работата завзема најголем дел од будните часови од деноноќието на луѓето. Работата е важна не само поради месечните примања, туку и поради тоа што влијае врз самодовербата на луѓето, создава можности за општествено значителни активности и резултира со производство на продукти или услуги кои се потребни за добро функционирање и напредок на една општествена средина. Значи, работата е високо ценета и со тоа се наметнува прашањето дали среќните и ментално силни луѓе се поуспешни на работните места.

Истражувањата покажуваат дека среќните работници уживаат во повеќе бенефиции споредени со не толку позитивните колеги [11]. Индивидуите кои имаат повисока субјективна благосостојба подобро поминуваат на интервјуа, подобро се евалуирани од страна на супервизорите кога ќе ја добијат работата, покажуваат подобар перформанс и продуктивност и подобро се справуваат со менаџирање. Исто така, поверојатно е дека нема да покажат контра-продуктивност и избувнување на работното место. Дури и пред да почнат да бараат работа, луѓето кои се позитивни поверојатно е да дипломираат на факултет, а подоцна да работат на подобри работни позиции со поголема автономија, значење и разновидност. Дополнително, луѓето со подобро ментално здравје и позитивни мисли се позадоволни со работите кои ги имаат [12]. 
Во едно детално истражување на тема „Позитивни емоции и поволните резултати на работното место“ (Стоу, Саттон и Пелд) [13] се поставени следниве неколку специфични врски со цел да се дефинираат општи хипотези во врска со тоа дека позитивните емоции имаат поволни резултати:

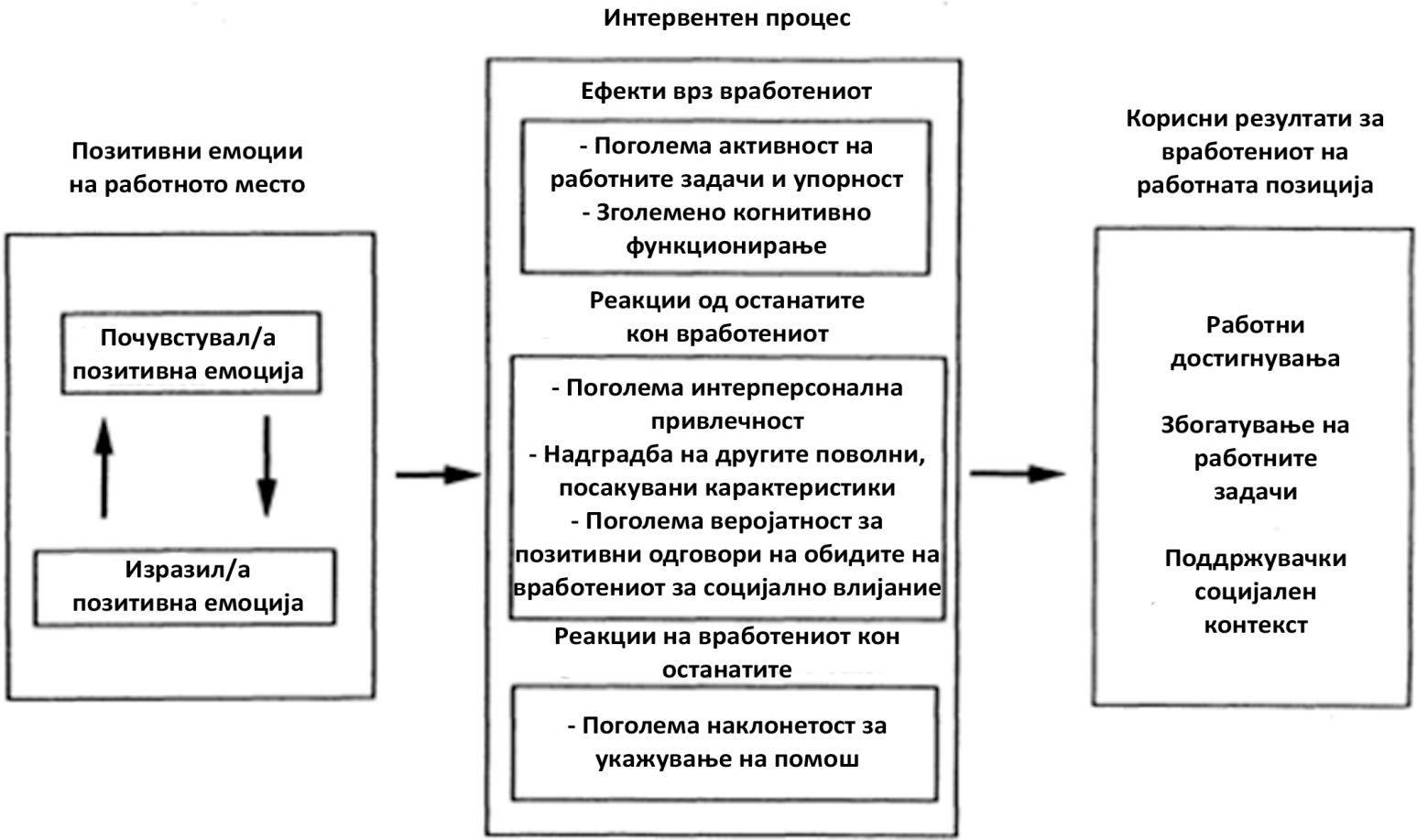

таб. 2.2.2-1 Графички приказ на врските кои покажуваат дека позитивните емоции резултираат со поволни резултати на работното место.

Според овој модел, позитивните емоции носат поволни резултати на работното место преку 3 процеси (Таб. 2.2.2-1). Најпрво, позитивните емоции имаат посакувани ефекти, независно од односот на една личност кон останатите, вклучувајќи поголема активност на зададените задачи, упорност и когнитивно функционирање. Второ, луѓето со позитивен став, наспрема оние со негативен, добиваат поволни одговори и реакции од луѓето со кои контактираат. Тие поуспешно влијаат врз останатите, а истовремено се и подопадливи поради што се случува ефект на повисоко рангирање на позитивните вработени според различни посакувани квалитети поврзани со работната позиција. Трето, поради пријатните и позитивни реакции овој тип на луѓе многу подобро соработуваат со колегите. Според ова, комбинацијата на горенаведените процеси води до добри резултати на работното место, вклучувајќи разни достигнувања како поволни супервизорски оценки и поголема плата, збогатување на работните обврски и значењето како и поддршка од страна на колегите и претпоставените. Хипотезите кои ги поставиле Стоу, Саттон и Пелд се следниве:

1) Вработените кои се попозитивни добиваат подобри евалуации за нивниот перформанс и повисока плата. 
2) Вработените кои размислуваат позитивно добиваат збогатени работни задачи со повисоко значење.

3) Позитивните вработени добиваат поголема социјална поддршка од страна на колегите и претпоставените.

Истражувањето користи информации собрани од страна на Истражувачкиот центар на Универзитетот на Мичиген на тема „Ефективноста во работните улоги: одговори на вработените на работните средини“. Податоците биле собрани двократно, вториот пат 20 месеци по првиот, а во истражувањето биле вклучени околу 272 вработени, мажи и жени, на просечна возраст од 37 години, вработени во болница и во 2 различни фабрики за производство на делови за автомобили.

Информациите биле собрани преку 4 методи. Најпрво, биле направени лични интервјуа кои вклучувале брзи прашања, отворени и затворени прашалници кои требало да се одговорат усно, прашања запишани на картички кои предизвикувале различни реакции и сл. Вториот метод се случувал на крајот на интервјуто кога интервјуерот ги снимал неговите обзервации во врска со неколку карактеристики на вработениот, вклучувајќи род и очигледно ниво на интелигенција. Третиот метод вклучувал теренски набљудувања додека вработените си ги вршеле работните задачи. Вработените биле набљудувани 2 пати (период 1 и период 2) по 60 до 90 минути. Првиот и вториот пат набљудувањето го вршеле различни лица. Четвртиот метод бил евалуација на вработените според 8 критериуми за нивното однесување на работното место во период 1 и период 2 од процесот на набљудување. Евалуацијата ја правел супервизорот на вработените.

Варијаблите во ова истражување се следните: предвидувачки, зависни и контролни варијабили. Главната предвидувачка варијабила - позитивни емоции на работа - била операционализирана преку скала која го мери нивото до кое вработените чувствуваат и изразуваат позитивни емоции на работното место во период на набљудување 1. Зависните варијабили се две мерки за работни достигнувања (евалуација од страна на супервизорот во период 2 и плаќање во период 2) и две мерки за социјалната средина (поддршка од супервизорот во период 2 и поддршка од колегите во период 2). Останатите контролни варијабили се образование, возраст, пол и интелигенција.

Споредена била врската помеѓу позитивните емоции на работата во период 1 и пет поволни резултати во период 2. Првата хипотеза, за тоа дека позитивните емоции резултираат со повисока евалуација и плата се покжала точна според конечните индекси. Позитивните емоции во период 1 имале силен ефект врз рејтинзите од супервизорите во период 2, и помал, но значаен ефект врз платата во период 2. Образованието се покажало како маргинално значаен предвидувач на платата. Втората хипотеза, дека позитивните вработени ќе имаат збогатени работни задачи во период 2 се покажала неточна затоа што позитивните емоции во период 1 имале 
многу мало влијание, речиси неважно, врз збогатување на работните задачи во период 2. Третата хипотеза, за социјална поддршка, се покажала точна. Позитивниот став во период 1 значајно влијаел врз поддршка од страна на супервизорот во период 2 и скромно влијаел врз поддршката од страна на колегите.

Од ова истражување се гледа дека, доколку сите други фактори се еднакви, луѓето кои се позитивни и емотивно стабилни добиваат почести промоции, позначајни работни задачи, се поценети од страна на клиентите, добиваат почести понуди за вработување, уживаат во поголема доверба од страна на колегите и работодавците. Тие, исто така, работат поупорно, побрзо и покреативно. Поради ова, од особено значење е разбирањето на исходите од различните емотивни ставови на работната позиција и истражување начини за поттикнување на позитивен однос кон работната средина, бидејќи врската меѓу позитивните вработени и напредокот на компанијата и општествените средини е силна (Граф.2.2.2-1).

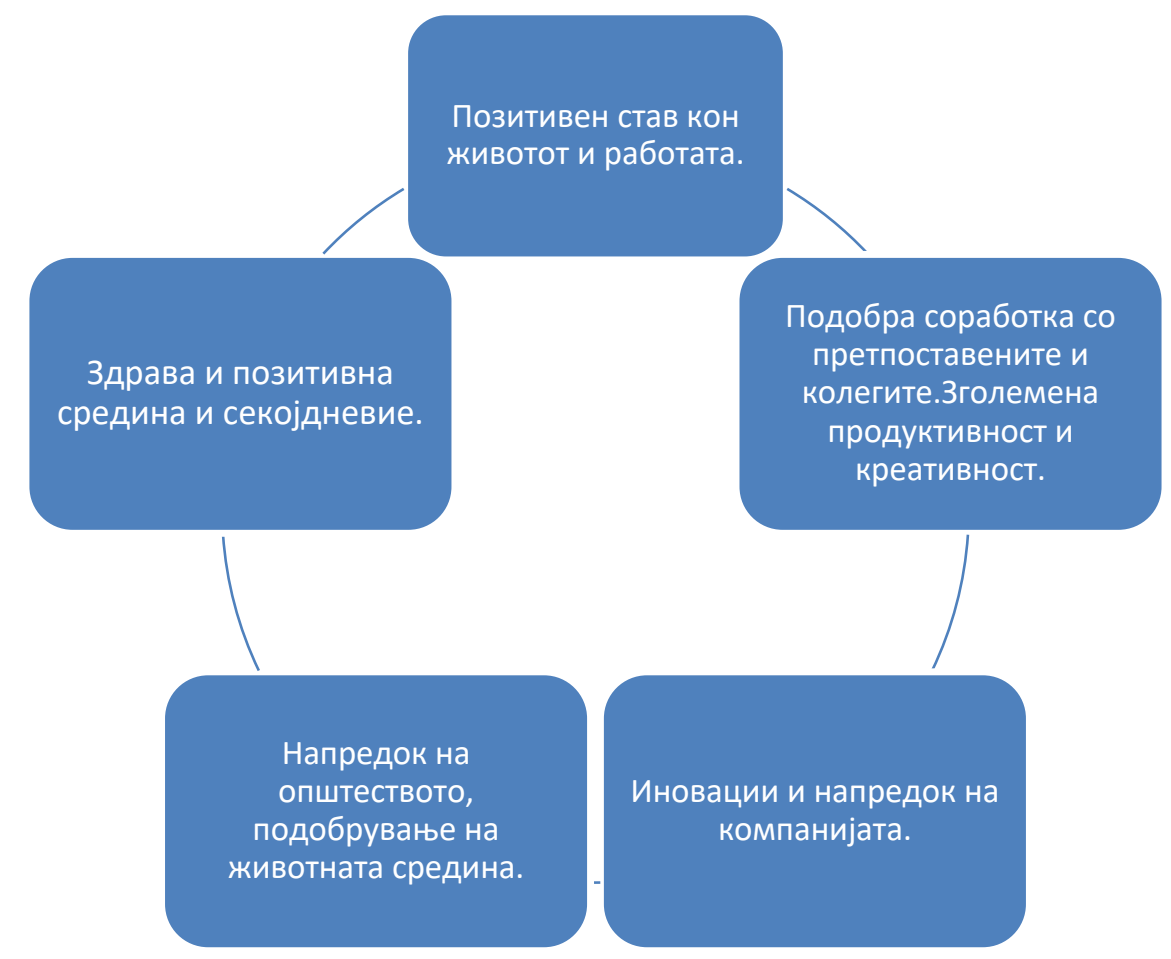

Граф. 2.2.2-1 Графички приказ на нераскинливата врска меѓу позитивните емоции и напредокот на едно опитество.

\subsection{3 Како урбаниот дизајн може да влијае врз подобрување на} менталното здравје и зголемување на позитивното расположение

Дизајнот е главен елемент во целото наше опкружување и значаен фактор во нашето секојдневие, па затоа се наметнува прашањето како може дизајнот на урбаните средини да го подобри физичкото, менталното здравје и позитивното расположение и да помогне во намалување на стресот. Урбаниот дизајн има 
возбудлив потенцијал во однос на позитивно влијание врз популацијата. Иако е постојано се потребни нови истражувања, архитектите, урбаните планери и проектантите низ светот веќе започнаа со следење на основни клучни точки за задоволување на барањата на позитивниот дизајн.

Основни принципи кои треба да се следат во урбанизмот за истиот да има позитивен ефект се [34]:

- Зелени површини;

- Активни зони;

- Про-социјални места и

- Безбедни места

Покрај овие 4 главни принципи, тука се и принципите на сон (сонот е важен за менталното здравје, а животот во градовите ги еродира шемите на спиење преку гужвите; бучавата од сирени, аларми, возила, градежни работи и соседи; светлинското загадување и визуелното загадување), mpaнспорт (добриот транспорт влијае врз ефикасноста на луѓето како и нивната можност за социјална интеракција, посета на природа и остварување останати слободни активности кои влијаат врз подобрување на менталното здравје), економски стрес (урбанизмот треба да помогне во намалување на економските разлики преку нудење на достапни места за одмор, подостапно домување и транспорт со цел да им се овозможи на сите да ги користат предностите на образовните, културните, и социјалните можности на градот) и загадување (загадувањето е актуелен проблем во сите урбани средини кој влијае негативно врз здравјето, а урбанизмот нуди повеќе можности за негово намалување преку зголемување на дрвјата и зелените површини кои ги заробуваат тешките метали, планирање на циркулација на воздухот, имплементација на мерки за намалување на сообраќајот, одделување на индустриските зони од останатиот дел на градот итн.).

\subsubsection{1 Зелени површини}

Врската меѓу зелените површини и менталното здравје е многу важна. Достапноста на природни средини во текот на секојдневието на луѓето го подобрува и оддржува менталното здравје и позитивното расположение. Природата е ефективна за генералната благосостојба, намалување на депресивноста, намалување на стресот, подобрено социјално и когнитивно функционирање, намалена агресивност и подобрено расположение, а начините преку кои овие бенефиции се овозможени се многубројни - зелените површини и природата: промовираат физичка активност, промовираат социјална интеракција, овозможуваат дистанца од секојдневните обврски, овозможуваат естетско уживање, овозможуваат подобрување на концентрацијата.

Од овие причини, зелените површини мора да бидат интегрирани во сите видови на урбан дизајн. Целосни зелени површини низ кои луѓето може да се движат, да се социјализираат и да вежбаат, имаат најголем ефект, но важно е жителите на 
еден град да се под константна и регуларна изложеност на урбана природа во текот на нивните дневни рутини, поради што елементи како улични дрвја и цвеќњња, погледи кон природни средини од прозорите на канцелариите, градини наменети за пауза за ручек и сл. се од голема важност. Шарлот Колинс, во нејзиното дело за урбани зелени средини и човеково здравје [19], зборува за квалитетот наспрема квантитетот на природни средини во еден град. Парковите и широките зелени пространства носат чувства на смиреност и намалување на стресот бидејќи се перцепирани како тивки, безбедни, непречени и свети места. Но, почестите (иако помали) природни опкружувања се покорисни бидејќи видливоста на дрвја и вегетација измешани во урбаната средина го намалуваат менталниот замор, агресивноста и стресот, додека нивен недостиг ја зголемува анксиозноста.

Џени Роу, во своите истражувања на тема архитектура, дизајн и здравје [14], зборува за потребата од „лек за начинот на живот“ во урбаните средини. Фактори во начинот на живот како што се физичката активност и доброволни активности во заедницата го намалуваат ризикот од негативно расположение и депресија. Како пример ја приложува Јапонската агенција за шуми која промовира практика т.н. "shinrin-yoku” (што во превод значи „шумско капење“) како дел од интегриран пристап за унапредување на здравјето. Дополнително, Хари Барнс, доктор од Шкотска, доделувал „зелени рецепти“ за лекување како на пример шумски прошетки или активности во блискиот парк. И двете од овие национални инцијативи за здравствена политика се засноваат на се поголем број на докази кои ги покажуваат позитивните својства на природните средини за подобрување на здравјето. Истражувањата варираат од епидемилошки студии на национално ниво кои го истражуваат менталното здравје [15], до локални студии кои ги истражуваат физичките и психолошките исходи кај популации кои страдаат од стрес [16] и истражувања на специфични проблеми со менталното здравје, како шизофренија и психоза [17].

Џонс Вокер, урбанистички проектант и професионалец за оддржливост, ја нагласува потребата од биофилни интервенции во урбаните места, прикажува примери на овој тип урбано планирање кои се интегрирани во Њујорк и предложува начини за влучување на биофилниот дизајн во урбаните проекти [18].

Биофилијата е всушност нашата длабоко вкоренета врска со природата, таа помага да се објасни зошто звукот на удирање на брановите или пукањето на огнот не пленат, зошто поглед кон пејсаж ја поттикнува нашата креативност, зошто сенките и височините кај нас будат фасцинација и страв или зошто дружењето и шетањето низ парк има обновувачки, лековити ефекти.

Рутинските врски со природата можат да обезбедат можности за ментална обнова, за чие време нашите повисоки когнитивни функции се одмараат. Когнитивното функционирање ја опфаќа нашата ментална агилност и меморија и нашата способност да размислуваме, учиме, да бидеме логични или креативни. На пример, насочено внимание е потребно за многу повторливи задачи, како средување документи, читање, вршење пресметки и анализи, управување во високостимулирачки средини како поминување улица во сообраќаен метеж или навигација во урбана стредина. 
Порастот на урбанизацијата носи должност за посветување посебно внимание во вклучувањето на природни области и елементи во градовите за да се задржи здравјето на жителите, бидејќи доколку постои невнимателност, дневното секојдневие на луѓето ќе опфаќа искуство и интеракција единствено со бетон, челик и стакло.

Вокер [18] зборува за Биофилна Урбана Акупунктура (БУА) што претставува теорија дека јазлите на биофилни интервенции во специфични урбани локации може да помогнат во подобрување на расположението, поврзување на луѓето и подобрување на менталното здравје. БУА има повисоко ниво на ефективност во густи градови наспрема приградски места поради пешачката мобилност. Жител на густ град во денот ќе помине барем одредено време надвор поради фактот што мора да оди до автобуска, метро станица, да оди до работа, да оди да земе јадење на ручек паузата итн. при што доаѓ до контакт со БУА интервенциите кои може да бидат големи или мали.

\section{Мали БУА интервенции}

Интервенциите на Биофилна Урбана Акупунктура не мора да се големи за да бидат ефективни. Позитивно влијание врз самодовербата и позитивното расположение се случуваат дури во првите 5 минути од контактот со природа. Дневно, ненамерно изложување треба да биде приоритет кога се планира БУА интервенција. Јазлите треба да бидат поставени на места каде има голема фрекфенција на движење во вид на мрежни локации низ градот со цел корисниците кои се движат кон различни дестинации да имаат биофилно искуство без разлика на конечната дестинација или на начинот на патување.

\section{Големи БУА интервенции}

Големите биофилни локации треба да бидат сместени во зони на градовите кои може да и служат на поголем дел од популацијата и треба да соджат што е можно повеќе биофилни шеми. Типично, ова се централните паркови кои имаат добра конекција до остатокот од градот за да бидат лесно достапни.

Примери за применета Биофилна Урбана Акупунктура

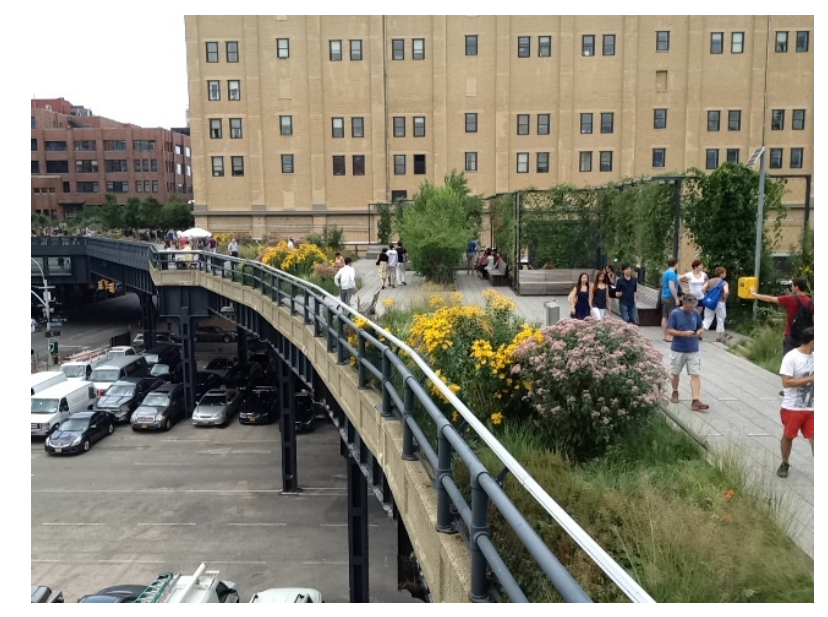

Сл.2.2.3.1-1 Биофилна интервенција на железничка пруга, Њујорк.

Стара железничка пруга претворена во биофилна интервенција во Њујорк. 


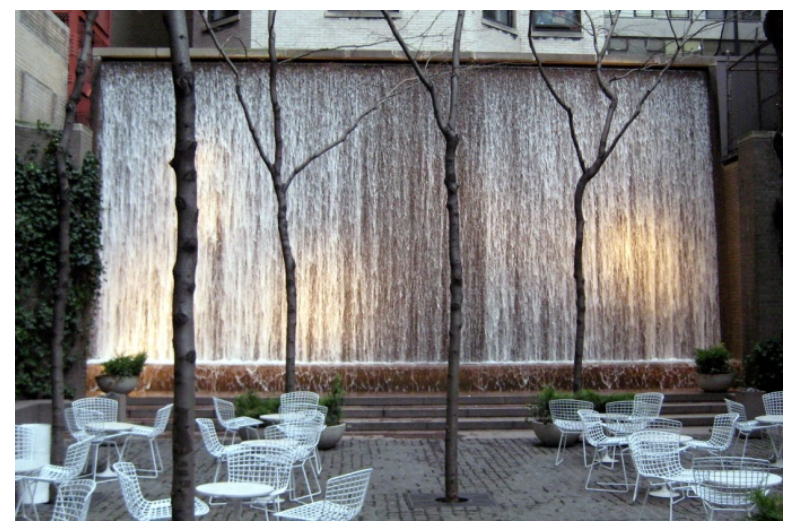

Сл.2.2.3.1-2 Водопад во Пејли Парк, Њујорк.

Водопад во Пејли Парк, Њујорк. Симулацијата на водни елементи буди чувство на привлечност и заносност. Комбинацијата на флуидност, звук, осветлување, близина и пристапност придонесуваат просторот да стане смирувачки и стимулирачки во исто време.

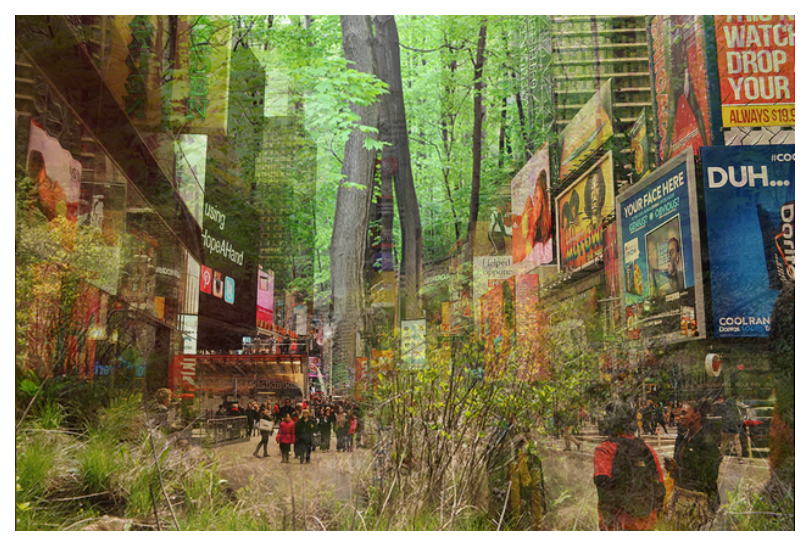

Сл.2.2.3.1-3 Предлог изглед на „Поп-ап" шума на Тајмс Сквер, Њујорк.

Предлог за „Поп-ап“ шума на Тајмс Сквер, Њујорк. Идеја за трансформација на урбана плаза во привремена, урбана инсталација на шума. Целта е да се покрене движење за ре-дефинирање на градовите размислувајќи за природата и да се креираат урбани оази кои ќе им помогнат на жителите да бидат во контакт со природниот свет.

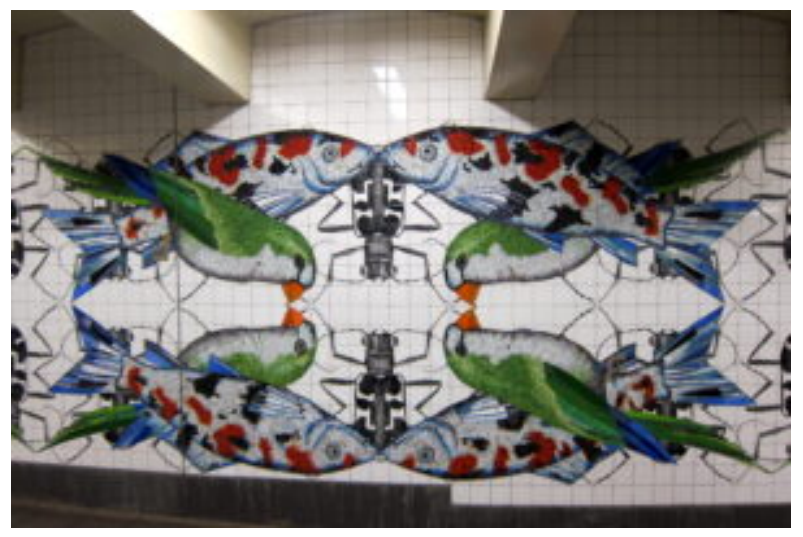

Сл.2.2.3.1-4 ऽидни илустрации на подземните метроа со природни елементи, Њујорк. 
Природни сцени и биоморфни форми и шеми на зидовите на подземните метроа, Њујорк. Идејата е дека уметнички погледи на природните системи како животински организми и различни растенија може да го вратат природниот дух и да ги трансформираат урбаните површини.

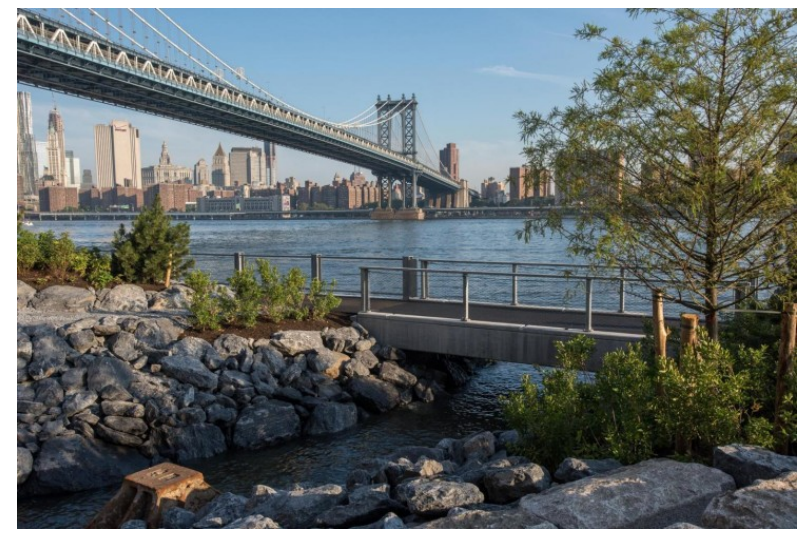

Сл.2.2.3.1-5 Екосистем на брегот, близу мостот во Бруклин.

Брегот кај паркот покрај мостот во Бруклин е пример за конекцијата помеѓу урбаниот пејсаж и локалниот екосистем. Зона која има добра поврзаност со природните системи буди свесност за животниот циклус и чувство на поврзаност со една поголема целина, чувство на смиреност, носталгија, па дури и длабоко просветлување.

\subsubsection{2 Активни зони}

Веќе е добро познато дека редовната физичка активност носи многу позитивни ефекти не само за физичкото здравје, туку и за менталното бидејќи редовното вежбање ја намалува депресивноста, анксиозноста и стресот и ја зголемува самодовербата и општата благосостојба. Точните механизми преку кои вежбањето влијае позитивно на менталното здравје не се целосно утврдени, но постојат неколку главни теории:

- Биохемија: Вежбањето го зголемува излачувањето на мозочните хемикалии вклучувајќи го серотонинот (поврзан со подобрување на расположението), а можеби има и невротрофичен мозочен фактор (ги зголемува невроните во мозокот).

- Сон: Вежбањето го подобрува сонот кој е заштитен фактор на менталното здравје.

- Самодоверба: Вежбањето влијае врз зголемување на чувството на важност и достигнување што ја зајакнува личноста.

- Отпорност на стрес: Вежбањето овозможува релаксација и развиток на поголема отпорност на стрес.

- Социјалност: Вежбањето нуди можности за позитивна социјална интеракција.

Урбаниот дизајн нуди можности за влијаење врз активноста на луѓето преку допирање до секојдневните рутини на жителите како што тие се движат низ градот каде живееме го дефинира начинот на кој живееме. Една од најголемите можности лежи во активниот транспорт, односно зголемување на безбедноста на пешаците и 
велосипедистите преку обезбедување на специјални пешачки и велосипедски патеки, велосипедски паркиралишта и добри конекции меѓу различни делови од градот за пешачењето и велосипедизмот да станат поатрактивни од возењето. На пример, податоците [35] покажуваат дека во САД дневните патувања со велосипед на децата и возрасните сочинуваат само $1 \%$ од вкупните патувања, за разлика од Холандија и други европски градови каде патувањата со велосипед се движат од $20 \%$ до $30 \%$ од вкупните дневни патувања, што се должи на соодветните услови за велосипедизам и пешачење. Фокусот во овие градови е поставен на подобрување на безбедноста од аспект на воведување ограничувања на брзината на возилата, проширување на тротоарите и местата за пешачење или возење велосипед, како и подолготрајни зелени семафори за пешаците. Други опции вклучуваат нудење на стимулации за напуштање на автомобилот дома како и добро организиран јавен транспорт кој ги мотивира луѓето да го користат и да пешачат од една до друга станица. На пример, во Лондон во почетокот на 2000 година се вовела сеопфатна велосипедска патека, повеќе паркиралишта за велосипеди, подобрувања на безбедноста во сообраќајот, а од 2003 и нов закон според кој на сите возачи на автомобили им се наплаќа влез во градот. Резултатот од овие мерки бил удвојување на патувањата со велосипед чиј процент достигнал $12 \%$ и намалување на велосипедските и пешачките повреди. Дополнителна можност за влијаење врз секојдневните рутини е поставувањето на простори за надворешни активности како надворешни теретани, пешачки патеки, патеки за трчање, фудбалски игралишта, тениски игралишта и сл.

Сите овие елементи имаат значително влијание врз тоа каде, кога, како и колку физичка активност ќе имаат граѓаните на дневна база. Па, како можат заедниците да ја започнат задачата за создавање простори и места кои промовираат активен начин на живот? При започнување на било каков урбанистички проект или проект за транспорт и развој во предвид треба да се земе неговото влијание врз здравјето како и влијанието врз животната средина. Ваквите промени ќе бидат есенцијални за постигнување на целта - физичката активност да стане редовен и природен дел од секојдневниот живот.
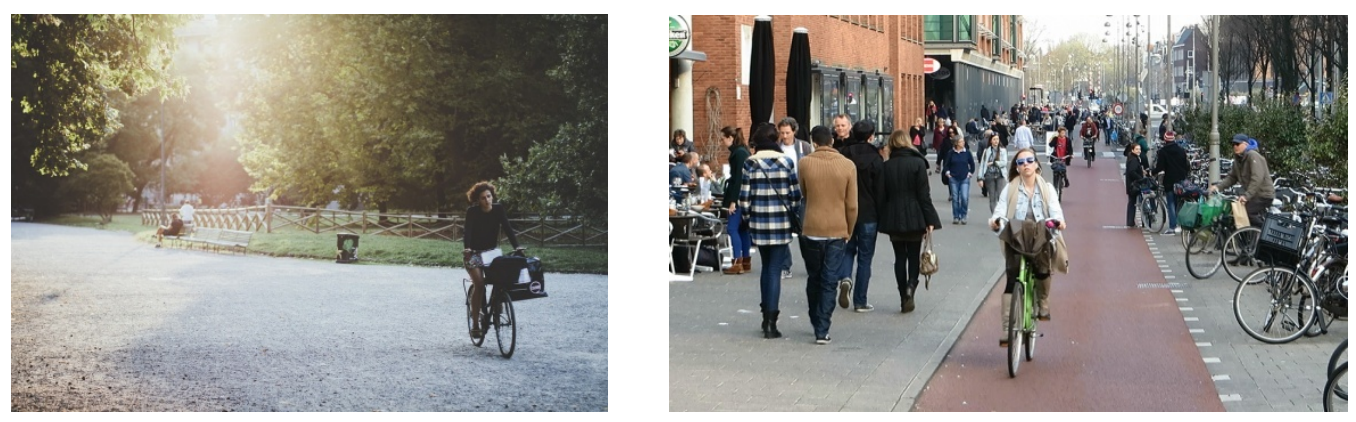

Сл.2.2.3.2-1 Примери за урбани средини кои ја поттикнуваат и подржуваат физичката активност на граѓaните. 


\subsubsection{3 Про-социјални места}

Една од најважните можности за промовирање на добро ментално здравје е остварување на природни, позитивни социјални интеракции, од блиски односи до чувство на припадност во една социјална, општествена заедница. Социјалните интеракции помагаат во соочување со предизвиците кои ги носи животот, ги зголемуваат чувствата на самодоверба и емпатија, а ги намалуваат чувствата на самотија, изолација и анксиозност. Регуларните социјални интеракции, исто така, можат да го подобрат когнитивното функционирање, особено меморијата и интелектуалната изведба.

Поради ова, урбаните места треба да имаат локации кои олеснуваат позитивна социјална интеракција (иако треба да нудат и можност за приватност). Компактните маала сами по себе нудат можности за природна, дневна социјална интеракција меѓу жителите, а засилување на оваа позитивна интеракција може да се постигне на повеќе начини. На пример, преку различни улични знаменитости кои го влечат интересот и овозможуваат комуникација меѓу луѓето кои ќе застанат да ги погледнат наместо директно да се движат кон канцеларијата или автобуската станица. Понатаму, останати можности лежат во добро организираните градски паркови, поставените клупи и летниковци, таблите за шах или пинг-понг во отворени средини, простори кои може да се искористат за здружување на луѓето при различни јавни настани во заедницата, како на пример добротворни концерти, активности и волонтирање итн.

Во истражувањето спроведено како дел од програмата „Центар за благосостојба“ (What Works Wellbeing Centre) [20] биле анкетирани професионалци од различни сектори (вклучувајќ практиканти, истражувачи во јавното здравство и развој на заедницата во рамките на локалната власт, третиот сектор и приватниот сектор од областа на општа благосостојба) преку онлајн анкета поврзана со благосостојбата на заедницата. Од вкупно 317 испитаници, 62\% верувале дека благосостојбата на заедницата се базира на „силни мрежи на односи и поддршка меѓу луѓето во заедницата, како и блиски односи и пријателства меѓу соседите и познајниците“. Дополнително, повеќето го делеле мислењето дека „благосостојбата е резултат на чувство на припадност во една зедница, чувство на безбедност во истата и можност за превземање акција со цел да се влијае во нејзиното подобрување“. На прашањето како може да се влијае за да се постигнат овие ефекти, испитаниците понудиле идеи за превземање на различни иницијативи како на пример, затворање на сообраќајот во одредени делови со цел да се поттикнат луѓето да излезат и да се дружат, обезбедување на места соодветни за социјализација, организација на различни групни активности (садење цвеќиња или чистење пред зградите и слично). Резултатите од оваа анкета покажуваат зошто, како и каде благосостојбата на заедницата може да биде движечката сила која ги оформува подобрите места за живеење и покажува како превземањето акција во овие места го оддржува оптимизмот.

Според Рианон Конкорон, професор по психологија и Грем Маршал, урбанистички дизајнер [20], преку усвојување на одредени максимуми на благосостојба како водилки при градењето на политиката за животна средина, професиите поврзани со животната средина може да го постават „процветувањето“ на луѓето во срцето на формалниот етос при креирање на едно место. Според нив, 
усвоените дизајнерски принципи недоволно успешно се фокусираат на потребите и реакциите на луѓето кон одредено место. Успешните урбанистички локации и служат на општествената средина, а доказ за тоа дека луѓето во општеството имаат корист од тоа место е нивната желба и потреба повторно да го посетат. Рианон и Грем предлагаат „пет чекори до благосостојба“ кои може да се имаат во предвид за да се добие добар дизајн (Сл.2.2.3.3-1).
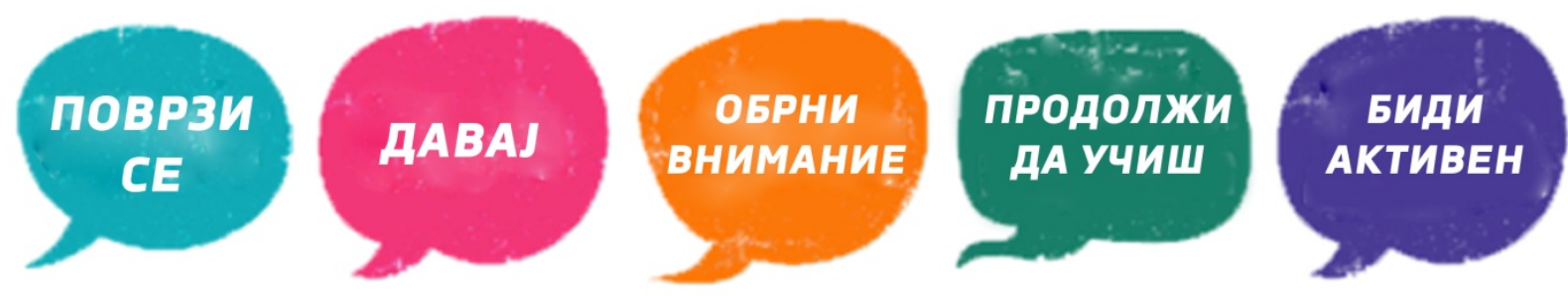

Сл.2.2.3.3-1 Петте чекори до благосостојба, според Рианон и Грем.

1) Конекција со останатите

Добар дизајн треба да им даде приоритет и да ги овозможи врските до и помеѓу потенцијалните центри и места за собирање и да ги отстрани бариерите во секојдневните социјални интеракции.

2) Давање (Алтрулизам)

Добриот дизајн треба да вклучува флексибилни места и средини кои даваат приоритет на соработка во заедницата. Кооперативните стремежи кон колективното добро се основа за благосостојбата во заедницата.

3) Обрнување внимание кон светот околу

Невронаучните докази покажуваат дека, освен доколку сме активно вклучени во процесирање на информациите кои ги примаме преку сетилата од надворешноста, имаме тенденција да тонеме во сопствените мисли, чувства и сеќавања. Дополнителни докази покажуваат дека лошото расположение доаѓа како тенденција на губење во внатрешниот свет со акцент на песимистички и загрижувачки мисли [21]. Според тоа, флексибилен, динамичен дизајн кој предизвикува, изненадува или го оттргнува вниманието на луѓето од нивните мисли или окупации се смета за дизајн кој влијае добро на благосостојбата. Добриот урбан дизајн треба да не натера активно да ги процесираме информациите од нашите опкружувања, да не натера да ги тргнеме главите од нашите паметни телефони или друга технологија и да го искусиме светот во реалноста, наместо виртуелно. Дополнително, ова помага да обрнеме внимание едни на други, и да се ангажираме социјално.

4) Учење

Добриот дизајн треба да биде ангажиран да им овозможи на индивидуите да развијат т.н. алоцентрична реакција кон местото, односно дизајнот и развојните процеси кои вклучуваат, запрашуваат и ги ангажираат луѓето во резултати и објективи поврзани со местото ќе им помогнат да продолжат да учат и да развијат разбирање за фундаменталните елементи и корисноста на тоа место за останатите, а не само за нив самите.

5) Активност

Добриот дизајн треба да овозможува и да поттикнува редовна секојдневна физичка активност. 


\subsubsection{4 Безбедни места}

Чувство на безбедност и сигурност е интегрално за добро ментално здравје и благосостојба. Урбаните опасности вклучуваат сообраќај, губење во просторот, загадувања на животната средина и опасности од други луѓе. Луѓе кои доживеале траума од типот на кражба или сведоштво на насилен криминал се подложни на нарушуено ментално здравје дури и по една година од инцидентот. Чувството на небезбедност го зголемува хроничниот стрес и нивоата на анксиозност, а луѓето кои живеат во помалку безбедни населби помалку излегуваат надвор за да шетаат или да се вклучат во било каква друга физичка или социјална активност.

Во прирачникот „Превенција од криминал преку дизајн на животната околина“ издаден од владата на Квинсленд [22] се наведени неколку принципи преку кои урбаниот дизајн може да влијае за зголемување на безбедноста:

1) Контрола на пристапноста: Дизајнот треба има јасни јавни рути и елементи кои го оневозможуваат пристапот до приватни објекти и земјишта, како влезови, огради, живи огради и дрвја и сл.

2) Надзор: Дизајнот треба да ја зголемува видливоста на локацијата, така што луѓето ќе се чувствуваат дека има прегледност на просторот, а жртвите на криминал може да побараат помош. Ова се постигнува преку поставување на соодветно осветлување на лицата наместо силни светла кои предизвикуваат отсјај и сенки, избегнување на елементи кои ја блокираат видливоста, поставување на прозорците на начин што ќе гледаат на пешачките патеки, обезбедување повеќе пешачки и велосипедски патеки кои се добро уредени и осветлени и сл.

3) Територијално засилување: Дизајнот треба јасно да ги демаркира јавните и приватните места.

4) Оддржување: Теоријата на „скршени прозорци“ нагласува дека елементи како искршени прозорци даваат импресија дека тоа маало толерира неред и е небезбедно.

Покрај ова, потребно е да се нагласи дека безбедноста не се однесува само на криминалот, туку таа се состои од повеќе елементи. Безбедноста во сообраќајот вклучува безбедни транспортни патишта со дизајн ориентиран кон луѓето со што се зголемува безбедното пешачење и велосипедизмот. Друга форма на безбедност е безбедната навигација, особено важна за луѓето со попреченост. Ова значи дека дизајнот треба да содржи елементи кои овозможуваат јасни ознаки и што се обележја за лесно движење низ просторот. 


\subsection{4 Заклучок од истражувањето}

Тод Литман во неговото истражување „Влијанието на урбанизмот врз менталното здравје и како да се креираат понормални и среќни градови“ [23] ги дели влијанијата врз позитивното расположение и менталното здравје во 3 категории: демографија, економија и животен стил и географија (Таб.2.2.4-1).

\begin{tabular}{|c|c|c|}
\hline ДЕМОГРАФСКИ & ЕКОНОМСКИ / ЖИВОТНИОТ СТИЛ & ГЕОГРАФСКИ \\
\hline $\begin{array}{l}\text { Се географски фактори - } \\
\text { групи со повисок ризик } \\
\text { живеат во градовите. }\end{array}$ & $\begin{array}{c}\text { Се географски фактори - економски и } \\
\text { животни услови со висок ризик } \\
\text { се концентрирани во градовите. }\end{array}$ & $\begin{array}{c}\text { Се својствени за урбаните услови - } \\
\text { се зголемуваат кога луѓето се селат } \\
\text { во градовите. }\end{array}$ \\
\hline $\begin{array}{l}\text { - Едукација, примања, богатство } \\
\text { - Возраст и фаза од животен циклус } \\
\text { - Семејство и брачен статус } \\
\text { - Семејство и социјални врски } \\
\text { - Здравствена состојба } \\
\text { - Користење дрога и алкохол } \\
\text { - Статус на малцинство } \\
\text { - Лични верувања и ставови }\end{array}$ & $\begin{array}{c}\text { - Интер регионална миграција } \\
\text { - Можности за образование } \\
\text { и вработување } \\
\text { - Животни трошоци } \\
\text { - Транспорт } \\
\text { - Криминал } \\
\text { - Социјален статус на урбани локации } \\
\text { - Физичка активност и фитнес }\end{array}$ & $\begin{array}{c}\text { - Можност за криминал } \\
\text { - Густина на население } \\
\text { - Изложеност на бучава и загадување } \\
\text { - Опции за транспорт (пешачење, } \\
\text { велосипедизам, јавен транспорт) } \\
\text { - Зголемена физичка активност } \\
\text { - Изложеност на природа } \\
\text { - Подобро известување проблеми }\end{array}$ \\
\hline
\end{tabular}

Многу фактори може да влијаат врз менталното здравје и среќа. Некои се асоцијации поврзани со типот на луѓе и активностите кои се лоцирани во градовите, наместо својствен ризик на урбаното живеење.

Таб. 2.2.4-1 Табеларен приказ на 3-те категории на фактори кои влијаат на менталното здравје и среќa.

Оттука е јасно видливо дека факторите на ризик од ментално заболување и појава на негативни мисли и песимизам не секогаш се директно поттикнати од урабнизацијата. Отприлика една третина од влијанијата врз позитивниот став на луѓето се поврзани со урбанизмот. Точно е дека стресното влијание на динамичниот урбанистички живот често резултира со умор, нервоза, анксиозност и депересија. Но, настрана од ова, животот во градовите би требало да поттикнува позитивен животен стил поради побогатите можности кои ги нуди, споредено со можностите во руралните средини - можност за подобра работна позиција, социјални интеракции, подобро школување и здравство итн. Тука главна улога игра урбаниот дизајн и начинот на кој градовите се организирани. Со добро осмислен урбанистички план и пристап на дизајнерите во чиј фокус ќе биде благосостојбата на луѓето може да се намалат факторите на ризик, а наспрема тоа да се зголемат факторите кои ги стимулираат припадниците на едно општество да бидат мотивирани, кретивни и позитивни во нивната работа и при секојдневните социјални интеракции. Општествена одговорност на дизајнерите е да се водат според психологијата на дизајнирање за среќа и рамките на позитивен дизајн за преку нивните иновации и креации да го подобрат текот на животот на граѓаните и да им помогнат да го достигнат сопствениот максимум, а со тоа и да се зголеми стремежот кон подобрување на општеството. 


\section{3. ЕТНОГРАФСКО ИСТРАЖУВАҢЕ}

Со цел да се добие јасна слика во врска со конкретната локална ситуација, односно кои елементи од досега изведените заклучоци важат и за државјаните на Р.Македонија, извршено е етнографско истражување.

При тоа, употребени се следните истражувачки методи за анализа на жителите на град Скопје: метод на набљудување и метод на испитување.

Memoдот на набљудување, односно опсервација, се дефинира како набљудување и евидентирање на однесувањето на испитаниците во различни ситуации [25]. Истражувачот може да го следи однесувањето на испитаниците во нивната природна средина, или пак, истото да биде направено во вештачки креирана средина. Во овој магистерски труд, опсервацијата се однесува на секојдневната природна средина на жителите на град Скопје. Дополнително, набљудувањето може да биде независно (присуство на испитаникот без негово активно вклучување во ситуацијата) или партиципативно (со вклучена социјална интеракција меѓу испитаникот и испитаниците). Употребениот метод на набљудување во овој труд е од независен вид. Извор на податоци кај овој вид на истражување е се што е вклучено во опкружувањето: физичката околина, физичките активности, фрекфенциите на интеракција и комуникација и сл. Собирањето на податоци се состои од 3 елементи:

- Дескриптивен дел - опис на учесниците, опис на околината, опис на настанот итн.

- Рефлективни забелешки - лични размислувања на истражувачот

- Демографски информации - информации во врска со местото и времето во кое се спроведува набљудувањето

Методот на набљудување е употребен во овој магистерски труд поради неговото позитивно својство на собирање точни информации на едноставен начин, без дополнителни трошоци. Податоците се точни поради фактот што субјектите на набљудување не се свесни дека се набљудувани и се однесуваат природно. Но, поради тоа што кај овој начин на колектирање на податоци фокусот е само на надворешното однесување, не може да се согледаат мотивите, ставовите и други внатрешни состојби, а информациите се собираат на нестандардизиран начин, ова истражување е потребно да се применува во комбинација со друг метод. Во овој конкретен случај, како дополнителен метод е употребен методот на испитување.

Meтодот на испитување е најчесто применуван метод, бидејќ најдобро одговара за собирање на квалитативни информации. Овој метод е погоден бидејки овозможува собирање податоци од испитаниците поврзани со нивните мислења, ставови, намери, преференции, чувства, идеи, како и информации во врска со нивното однесување и нивните демографски карактеристики [25]. Овој метод може да биде 
искористен преку квалитативни техники (фокус групи и длабински интервјуа) или квантитативни техники (анкети и панели). Понатаму, методот може да биде искористен во форма на структурирано или неструктурирано испитување. Во овој магистерски труд, употребен е методот на испитување со квантитативни техники преку анкетен прашалник, во структурирана форма - со структурирана форма на прашања кои на испитаниците се поставуваат на сосема ист начин.

\section{1 МЕТОД НА НАБЉУДУВАЊЕ}

Набљудувањето се одвиваше континуирано и непрекинато, секојдневно подолг временски период. Издвоени се неколку карактеристични ситуации кои го отсликуваат однесувањето на жителите на град Скопје за време на работните денови. Ситуациите се прикажани преку фотографии и кратки коментари.

\section{СИТУАЦИЈА 1}
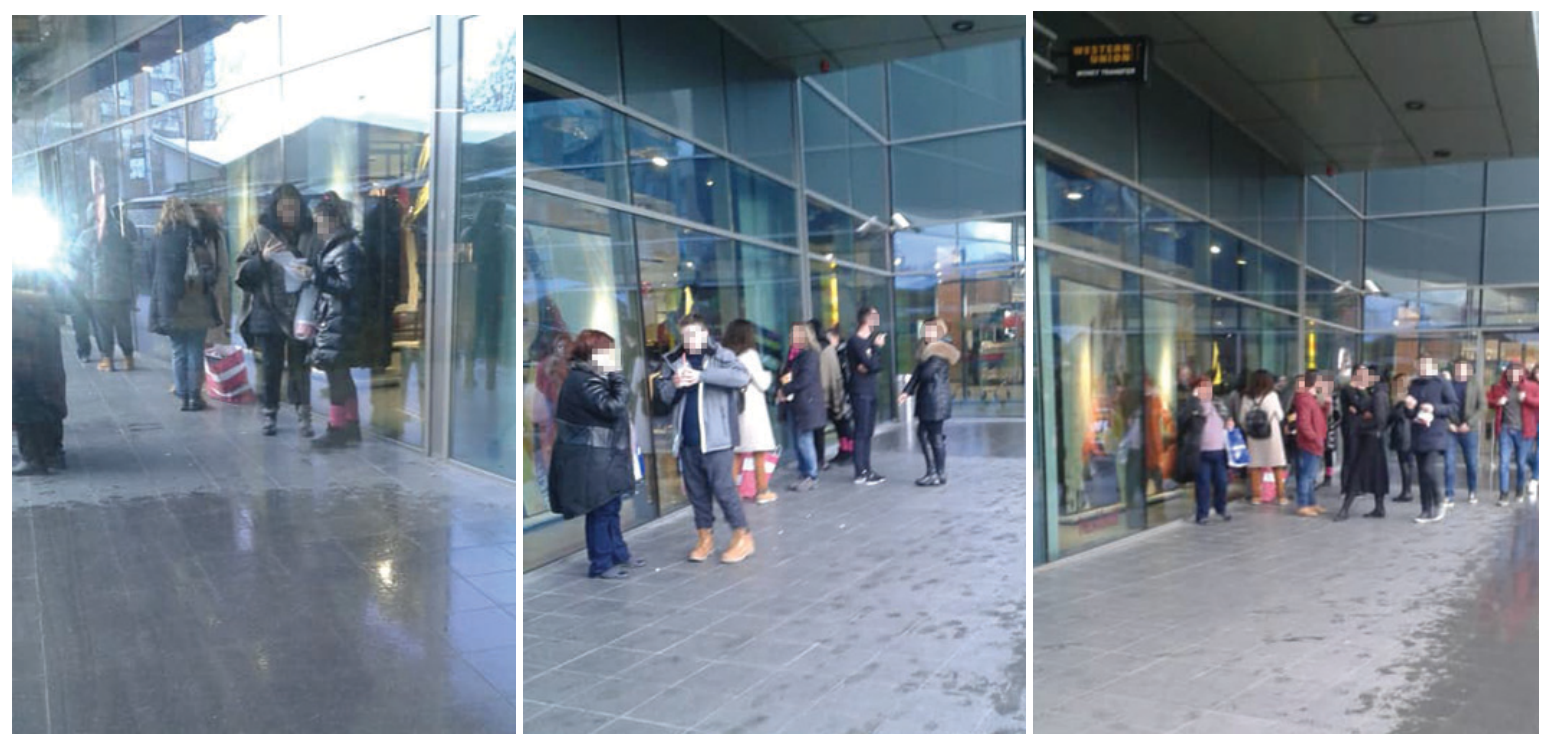

Сл.3.1-1,2,3 Фотографии од Ситуација 1 од спроведеното набљудување.

Овие фотографии се снименипред трговски објект во текот на работно време на дождлив ден. При набљудувањето повеќе вработени од трговскиот објект излегуваа на кратка пауза, вообичаено за кафе, внимавајќи да стојат под стреата за да се заштитат од дождот. Стоеја заедно со случајните минувачи кои исто така бараа засолниште под стреата. 


\section{СИТУАЦИЈА 2}

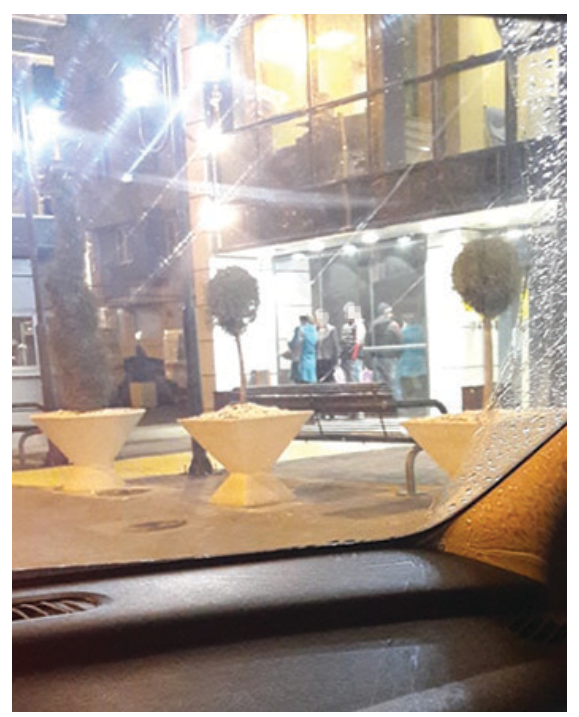

Сл.3.1-4 Фотографија од Ситуација 2 од спроведеното набљудување.

Оваа фотографија е „уловена“ од автомобил во друг дождлив ден, при крај на стандардното работно време. Група на вработени очигледно беа излезени на пауза и стоеја пред канцеларискиот објект, криејќи се од дождот под стреата на самиот влез, разговарајќи и пиејќи кафе, по што влегоа назад во објектот.

\section{СИТУАЦИЈА 3}

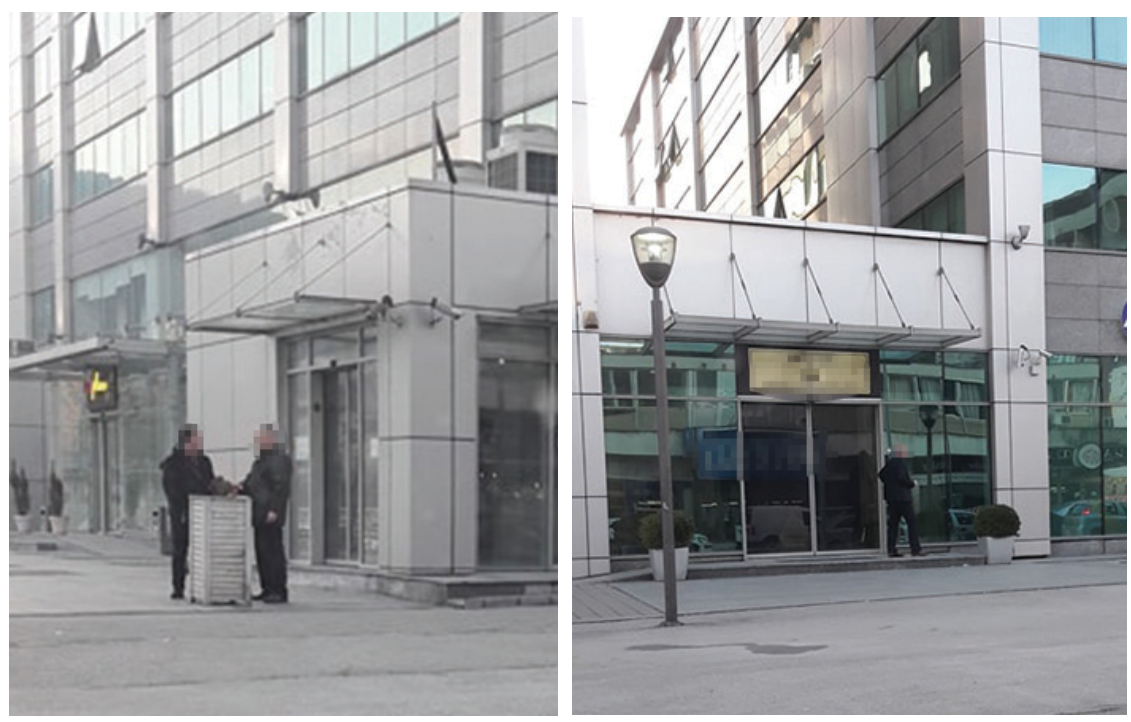

Сл.3.1-5,6 Фотографии од Ситуација 3 од спроведеното набљудување.

На фотографиите се прикажани вработени кои се излезени на пауза пред нивниот канцелариски објект. Двајцата колеги на левата фотографија пиеја кафе користејќи го високиот контејнер како маса за да ги остават чашите. Многу блиску до нив, уште еден вработен од истиот објект беше излезен на кратка пауза за цигара и телефонски разговор, по што се врати назад во објектот. 


\section{СИТУАЦИЈА 4}

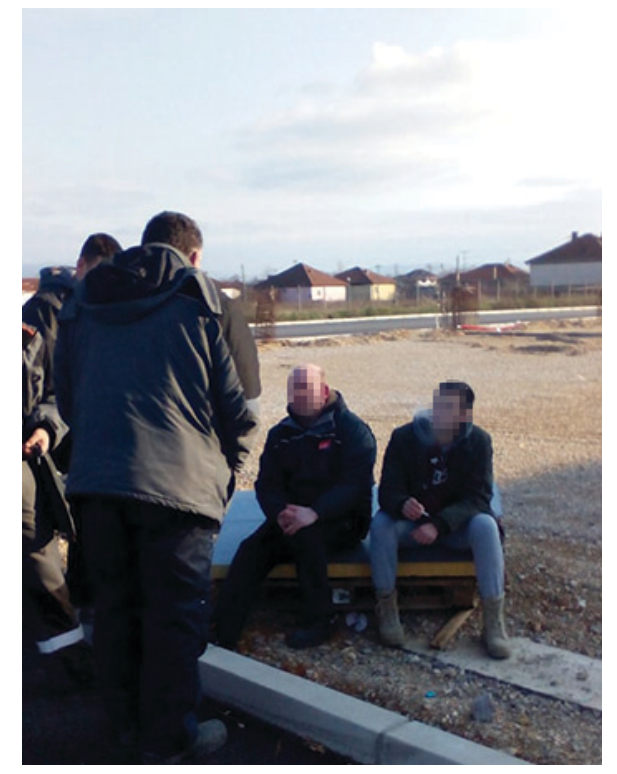

Сл.3.1-7 Фотографија од Cитуација 4 од спроведеното набљудување.

Фотографијата ги прикажува вработените од една компанија за прехранбени производи кои се излезени од нивните канцеларии околу пладне за да ја искористат паузата. Вработените јадеа, пиеја кафе, разговараа меѓусебно и на телефон, по што се вратија назад на работа. Бидејќи во околината на објектот нема место за седење, тие имаат поставено палети кои ги користат како клупи за одмор на отворено.

\section{СИТУАЦИЈА 5}
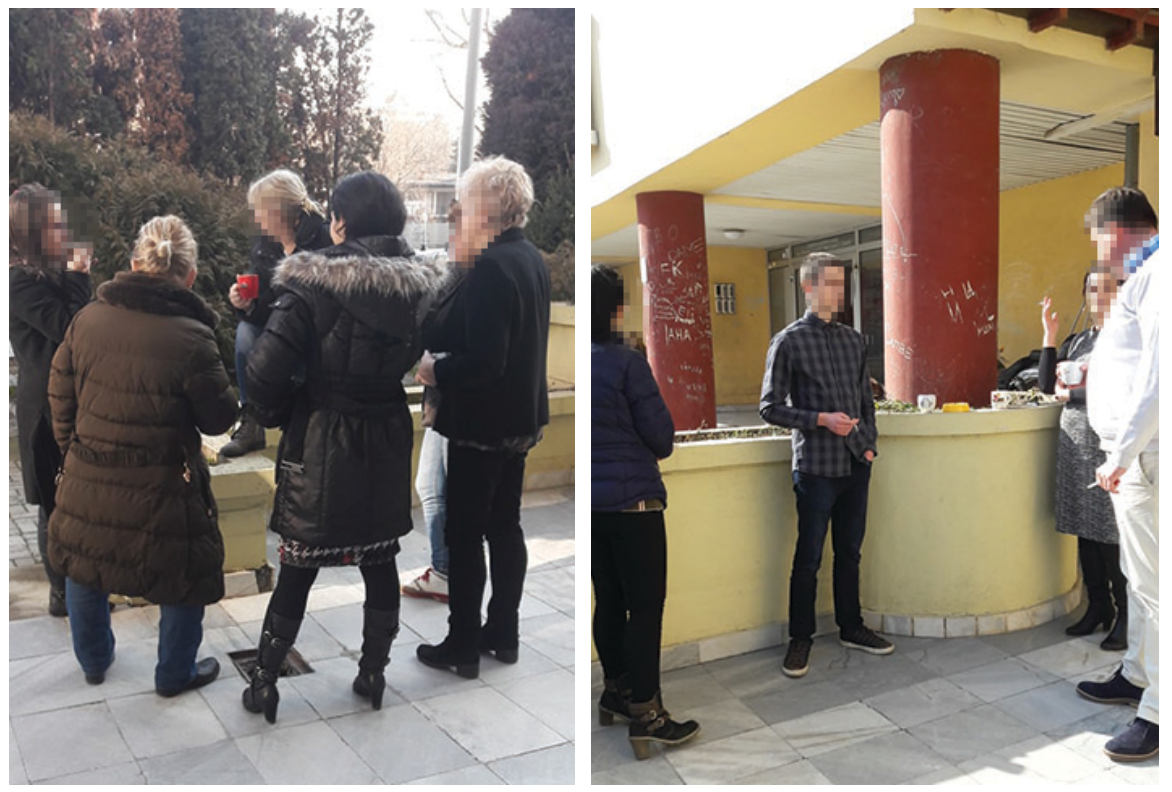

Сл.3.1-8,9 Фотографии од Ситуација 5 од спроведеното набљудување.

На двете фотографии погоре се прикажани вработени од една фирма кои користат пауза застанати групно пред канцеларискиот објект каде што работат, користејќи го зидот од самата зграда за да се потпрат, да ги остават чашите со кафе и пепелниците. 


\section{СИТУАЦИЈА 6}
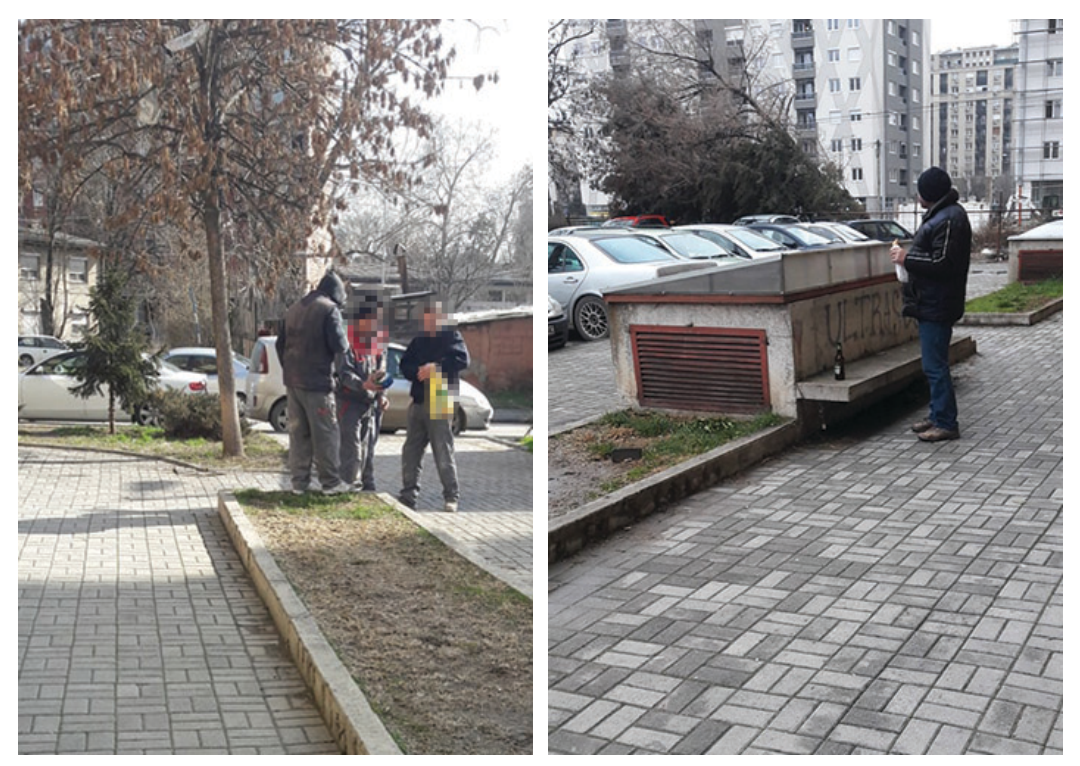

Сл.3.1-10,11 Фотографии од Ситуација 6 од спроведеното набљудување.

Група вработени, очигледно на пауза за доручек, јадеа пред маркетот од каде што ја имаа купено храната, вадејќи го јадењето од кесите. Пред маркетот имаше мали бетонски клупи, но бидејќи денот беше студен никој не седеше, доручекот го изедоа набрзина, на нога, по што си заминаа.

\subsection{1 Заклучок од метод на набљудување}

Она што може да се заклучи од спроведеното набљудување е очигледно вработените жители на град Скопје немаат доволно соодветни места каде во текот на денот може да се одморат од работа, да доручкуваат и ручаат, да се напијат кафе, да се социјализираат со своите колеги, или пак, да работат надвор од нивниот стандарден работен простор - да истражуваат, да одржат состанок и сл. Ова е особено нагласено за време на студените и дождливи денови кога може да се забележи дека вработените имаат потреба да излезат надвор, но немаат каде да ги поминат паузите. Кога времето надвор е потопло, тие ги користат околните клупи или паркчиња, доколку постојат во близина на местото каде работат, но овие урбанистички елементи ретко се во добра состојба. Генерално, може да се согледа дека фирмите не предвидуваат соодветен надворешен простор за одмор и релаксација кој би ја стимулирал креативноста и продуктивноста на вработените лица. 


\section{2 МЕТОД НА ИСПИТУВАҢЕ (АНАЛИЗА НА АНКЕТЕН ПРАШАЛНИК)}

Спроведениот анкетен прашалник беше наменет за возрасни лица, од 20 до 60 години, кои се вработени и се жители на град Скопје. Главната цел при формулирањето и спроведувањето на оваа анкета беше да се истражи начинот на живот и навиките на вработените жители на град Скопје и како тие се чувствуваат при вршење на секојдневните обврски. Поконкретно, да се согледаат причинителите за зголемување на стресот во нивното секојдневие и да се увидат начини кои би можеле да помогнат за негово редуцирање, односно да се увиди како може да се влијае врз секојдневните навики на граѓаните и со тоа да се подобри нивното психичко здравје, продуктивност и креативност.

Анкетата содржи 21 прашање, а на истата одговорија вкупно 50 испитаници од машки и женски пол, на различна возраст, вработени на дијаметрално различни работни позиции во институции во јавна администрација и во приватниот сектор (медиуми; компании за софтверски развој; трговски фирми за увоз, извоз и дистрибуција на производи).

Првите две прашања се однесуваат на полот и возраста на испитаниците. Анкетата ја пополнија приближно ист број на припадници од машки и женски пол и приближно ист број на испитаници од различните возрасни категории кои се наведени, со цел да се добие една глобална слика за животот на вработените во Скопје.
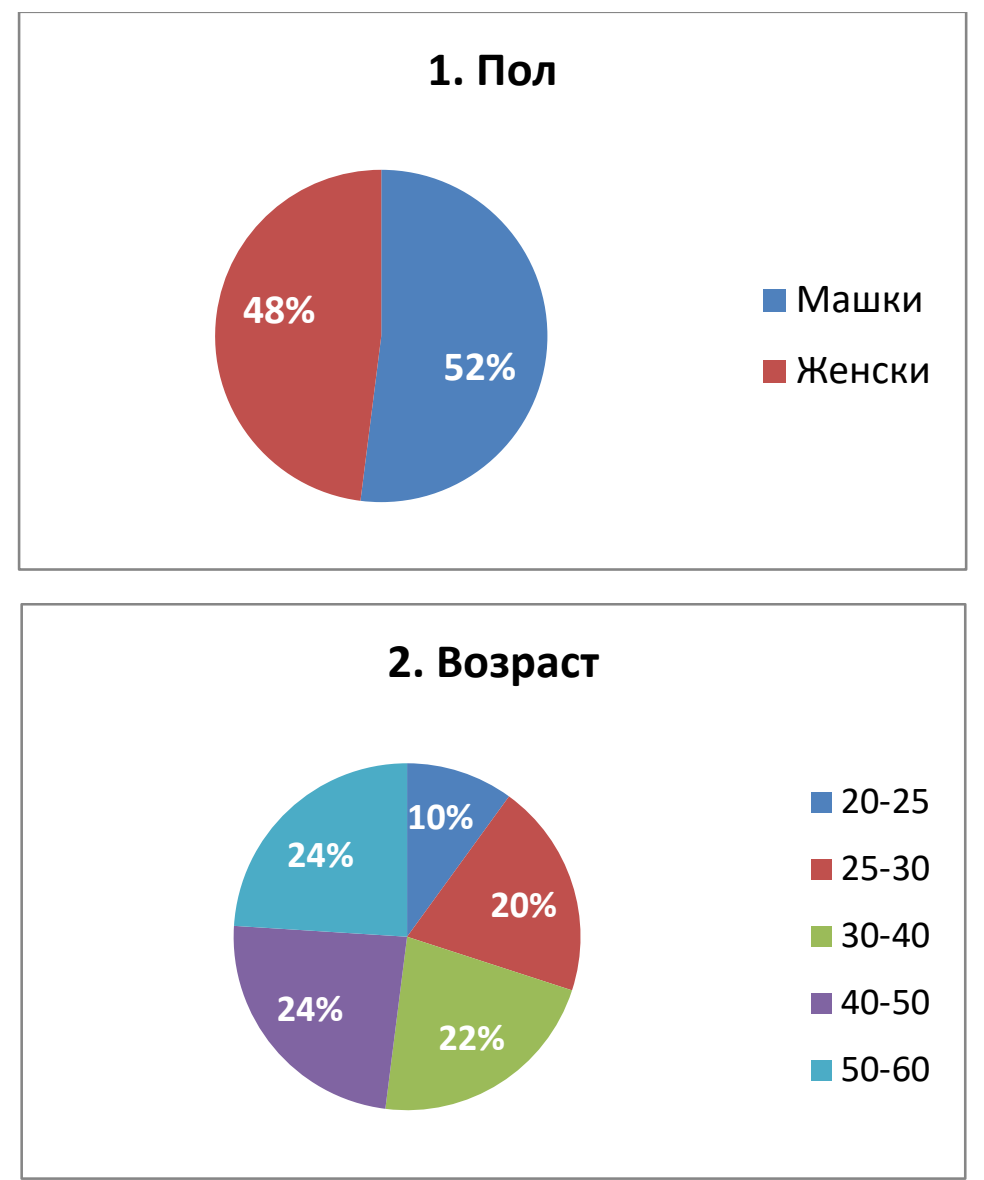

Граф. 3.2-1,2 Графички приказ на резултатите од прашањата 1 и 2 од анкетниот прашалник. 
Одговорите на следните неколку прашања од анкетата покажуваат колку време од денот луѓето всушност поминуваат на работното место и колку време за одмор имаат додека се на работа, за што и каде можат да го искористат тоа време за одмор и колку се задоволни од просторот каде ги минуваат слободните минути.
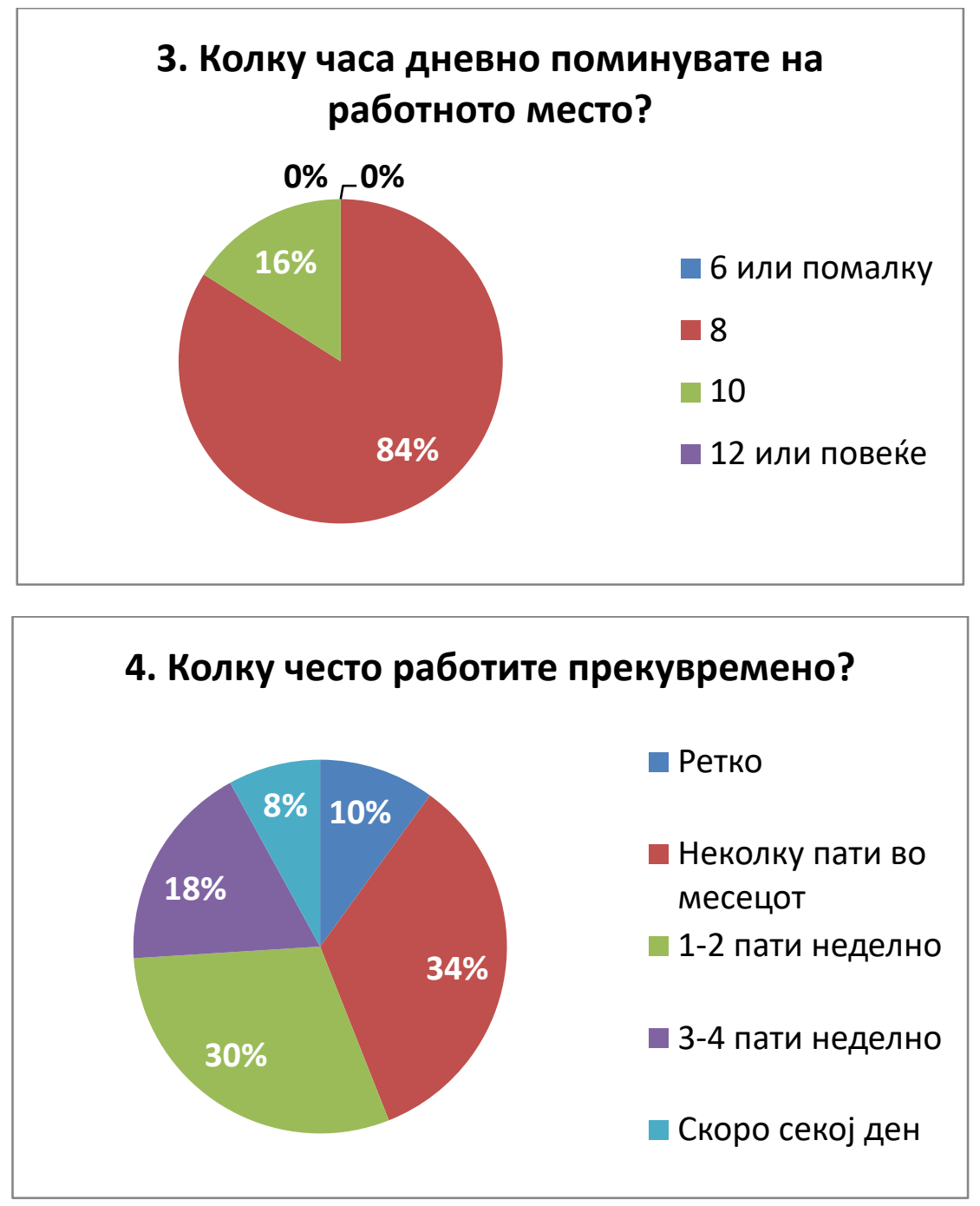

Граф. 3.2-3,4 Графички приказ на резултатите од прашањата 3 и 4 од анкетниот прашалник.

Лицата го минуваат најголемиот дел од денот на своите работни позиции, од 8 до 10 часа, со честа прекувремена работа - најголем дел од испитаниците работат прекувремено неколку пати во месецот и 1-2 пати неделно. 
5. Колку вкупно време поминувате на пауза?

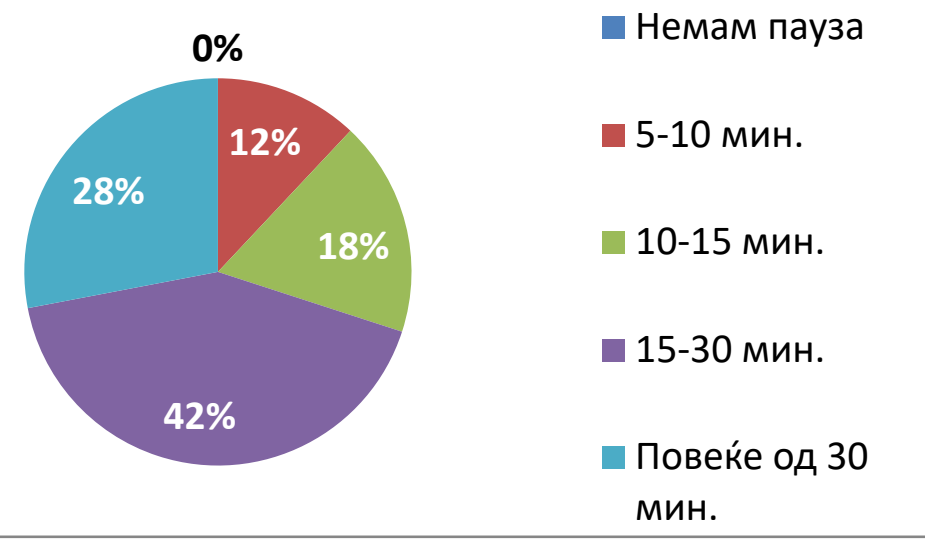

\section{6. Каков е просторот каде ја минувате}

$$
\text { паузата? пијна / бифе }
$$

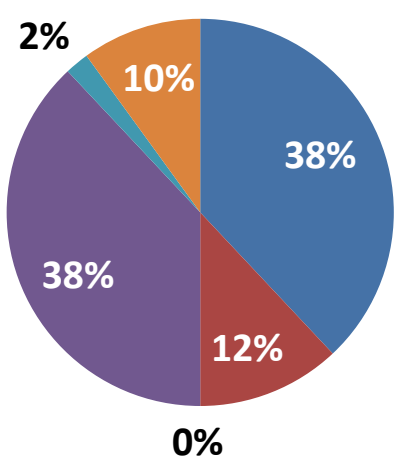

- Простор предвиден за одмор во работниот објект

Простор предвиден за одмор надвор од работниот објект

П Простор во или надвор од работниот објект кој не е

наменет и уреден за пауза - Кафуле, ресторан и сл.

Парк, клупи и сл.

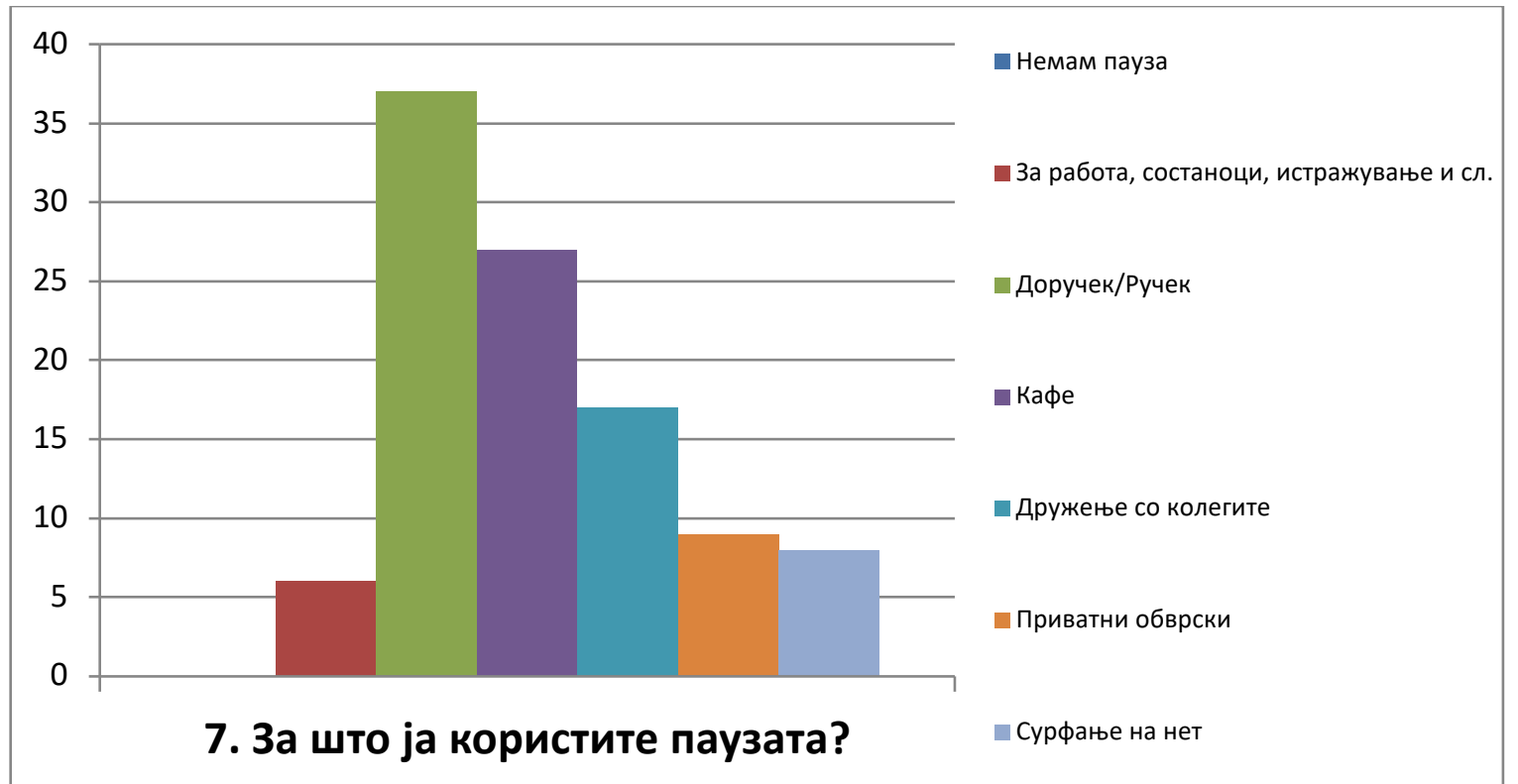




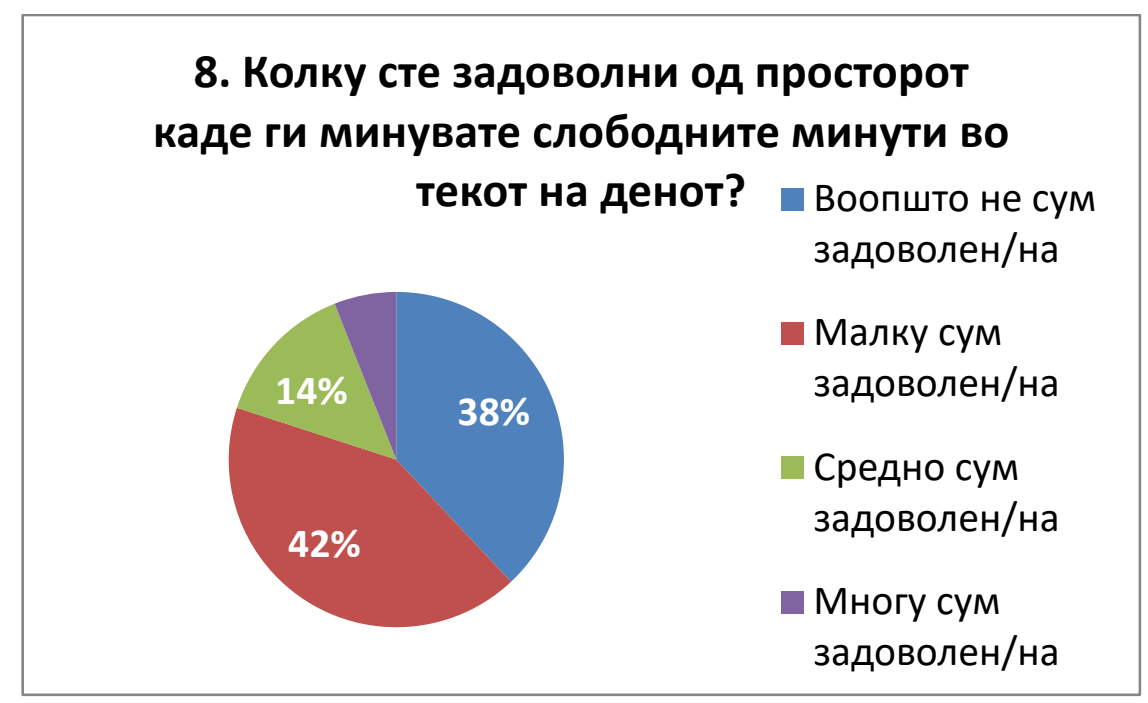

Граф. 3.2-5,6,7,8 Графички приказ на резултатите од прашањата 5,6,7 и 8 од анкетниот прашалник.

При анализирање на одговорите на прашањата наведени погоре, јасно е видливо дека и покрај тоа што вработените имаат релативно доволно време за пауза повеќето користат пауза од 30 или повеќе минути во текот на денот, сепак истите не ја користат максимално. Според резултатите, паузата најчесто се користи единствено за конзумирање на дневен оброк или кафе. Малкумина користат пауза за други продуктивни активности или за активности кои ќе им овозможат соодветен психички одмор во текот на денот. Ова веројатно се должи на несоодветниот простор предвиден за пауза - поголемиот дел од испитаниците одговориле дека паузата ја поминуваат во простор во или надвор од работниот објект кој не е наменет, ниту соодветно уреден за поминување на пауза. Останатиот дел од испитаниците паузата ја минуваат во кујна/бифе во работниот објект што е повторно врзано едниствено за пауза наменета за јадење или кафе. Во однос на прашањето дали се задоволни од просторот каде ја минуваат паузата, повеќето одговориле дека воопшто не се задоволни и дека малку се задоволни - просторот не им се допаѓа, но барем има каде да ја поминат паузата и да се оттргнат од работното место.

Следното прашање беше поставено за да покаже дали луѓето чувствуваат дека просторот во кој работат и ја минуваат паузата може да влијае врз нивното расположение и продуктивност во текот на денот. Како што беше очекувано, повеќето одговорија потврдно, дека просторот многу влијае врз нив. 


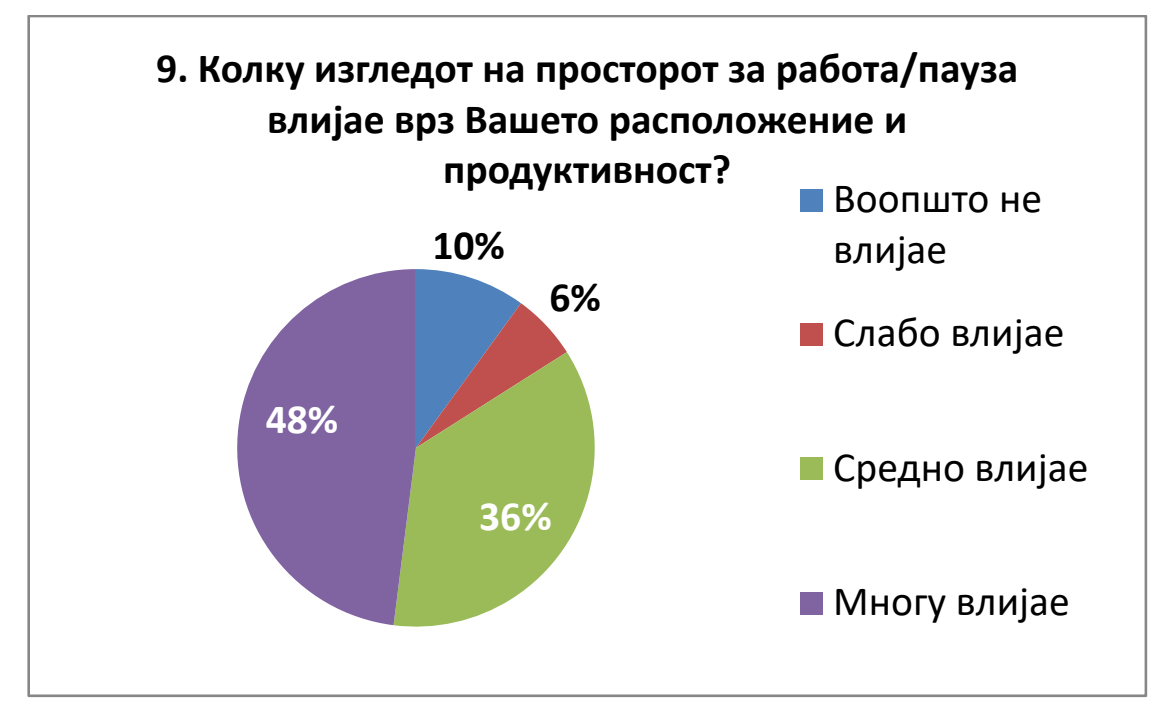

Граф. 3.2-9 Графички приказ на резултатите од прашањето 9 од анкетниот прашалник.

Понатамошните прашања се наменети за разоткривање на начинот на кој лицата се чувствуваат во текот на денот и нивните размислувања во однос на тоа што сметаат дека би им помогнало да се релаксираат, да бидат посреќни, позадоволни и попродуктивни за одговорите да бидат од помош при генерирање идеи за дизајнерски решенија кои ќе им го овозможат тоа.

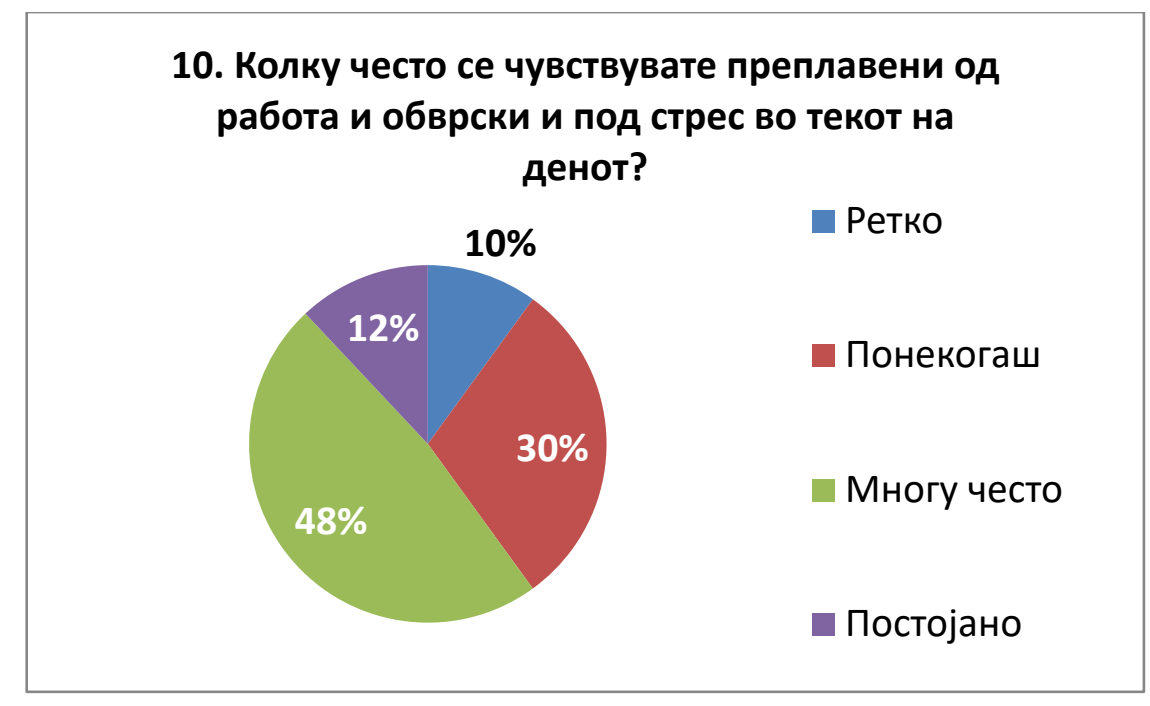




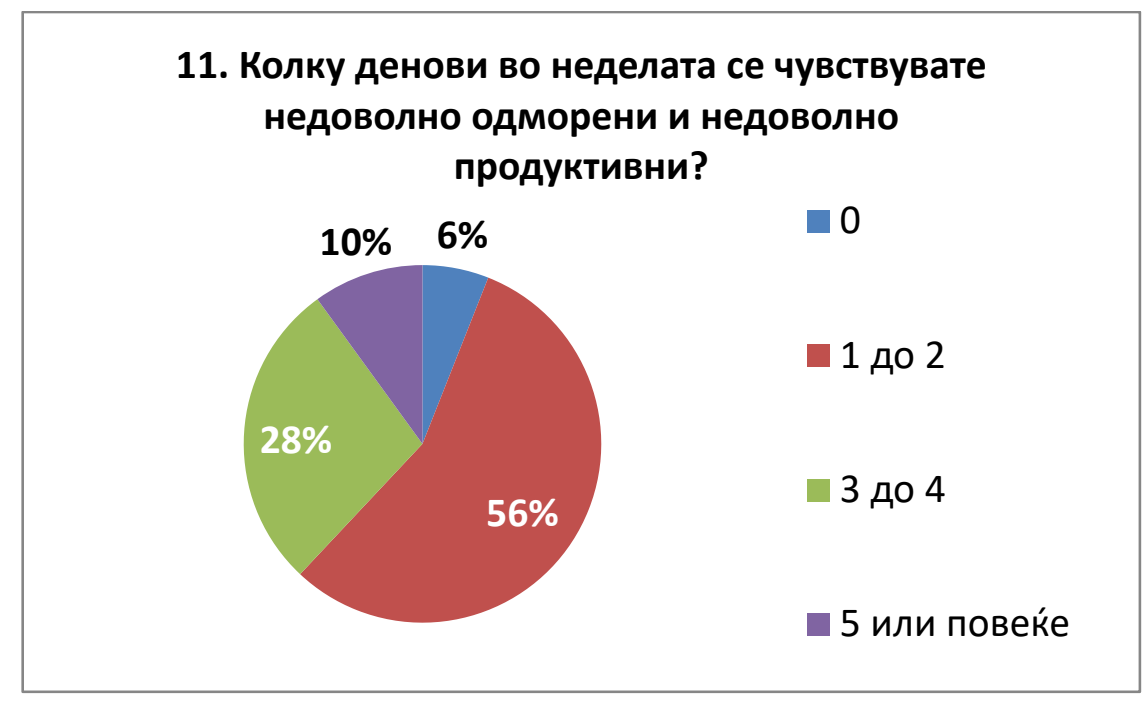

Граф. 3.2-10,11 Графички приказ на резултатите од прашањата 10 и 11 од анкетниот прашалник.

Резултатите се јасни индикатори дека лицата го имаат проблемот со справување со секојдневниот стрес бидејќи многу често се чувствуваат преплавени од обврски, недоволно одморени и недоволно продуктивни. Видливо е дека има потреба од спроведување на соодветни мерки за подобрување на нивното секојдневие. Во таа насока, следните прашања се наменети за анализа на потребите на испитаниците.

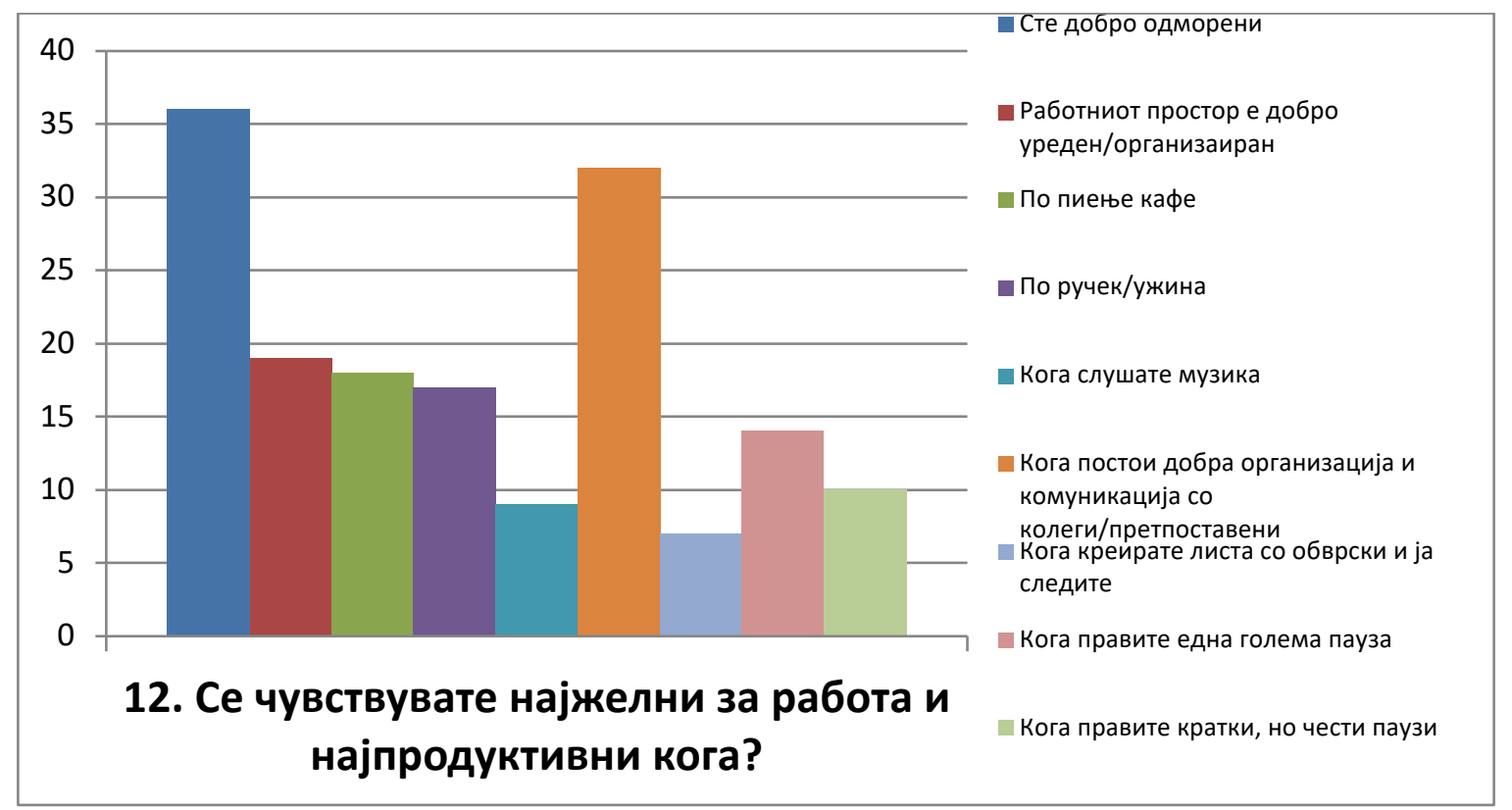

Граф. 3.2-12 Графички приказ на резултатите од прашањето 12 од анкетниот прашалник.

Од резултатите е видливо дека како предуслов за максимална продуктивност најмногу отскокнуваат факторите - добар одмор и добра, позитивна организација и комуникација меѓу колегите и претпоставените. Добриот одмор е од големо значење за добро функционирање на умствената активност, а добра комуникација меѓу колегите е возможна само кога секоја од индивидуите има позитивен став и желба за работа и решавање на проблемите на ефикасен начин. Поради тоа, за една компанија 
е од клучно значење вработените да бидат задоволни со цел истата да може подобро да напредува. Покрај овие два фактори, одговори кои беа најчесто одбрани од испитаниците како предуслов за продуктивност се $и$ - добро уреден и организиран работен простор (што повторно укажува дека просторот влијае врз психичката состојба) и време за ручек/ужина и кафе.

Следното прашање е во однос на тоа што луѓето мислат дека ја стимулира нивната креативност. Тука, повторно како одговор отскокнува потребата за одмор добар сон и одмор во текот на денот, како и престојот на отворено и разговарањето (брејнсторминг). Овие одговори се надоврзуваат на одговорите на претходното прашање.

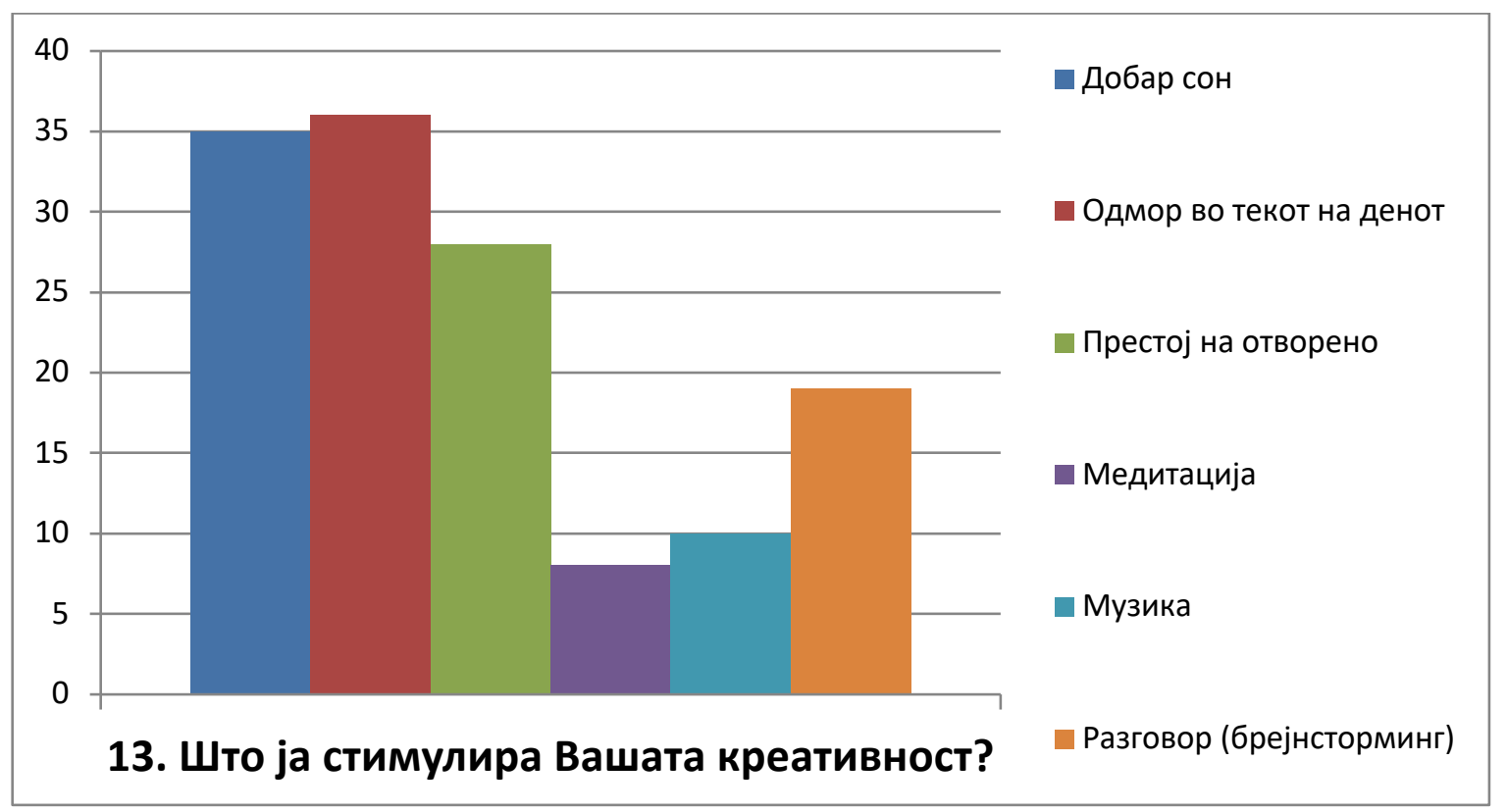

Граф. 3.2-13 Графички приказ на резултатите од прашањето 13 од анкетниот прашалник.

На прашањата - дали би биле посреќни доколку имаат време за пауза сами или со своите колеги на место соодветно уредено за таа намена и дали дополнителната работа би им била полесна доколку ја вршат на релаксирано место надвор од стандардниот работен објект - најголем дел од испитаниците, скоро 90\%, одговориле потврдно што значи дека имаат реална потреба од таков простор. 

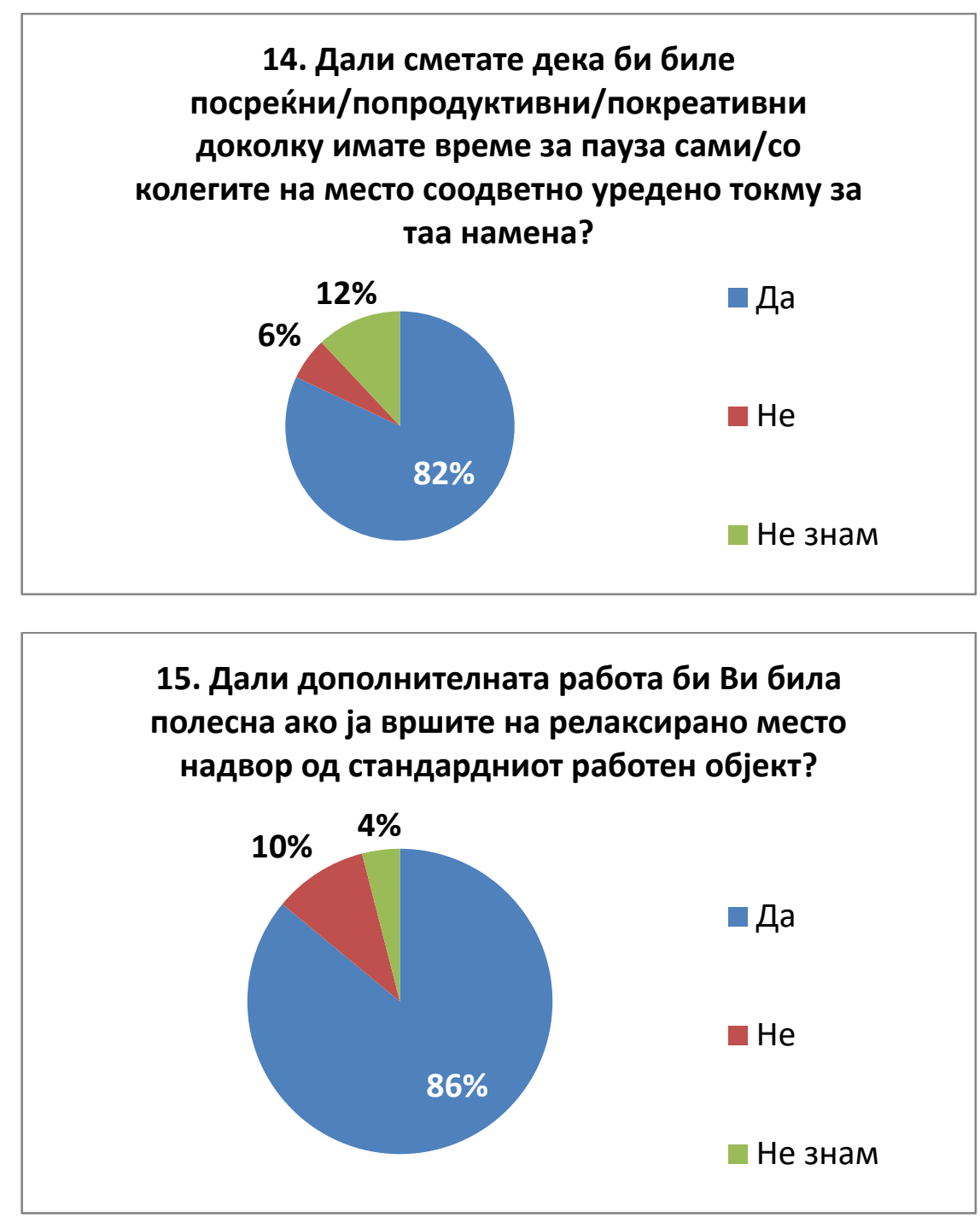

Граф. 3.2-14,15 Графички приказ на резултатите од прашањата 14 и 15 од анкетниот прашалник.

Следните неколку прашања од овој анкетен прашалник се однесуваат на останатите секојдневни навики на жителите, во она мало преостанато време во текот на денот кога не се на работното место, со цел да се увидат дополнителни причинителни на стрес и нарушување на психичкиот баланс. 


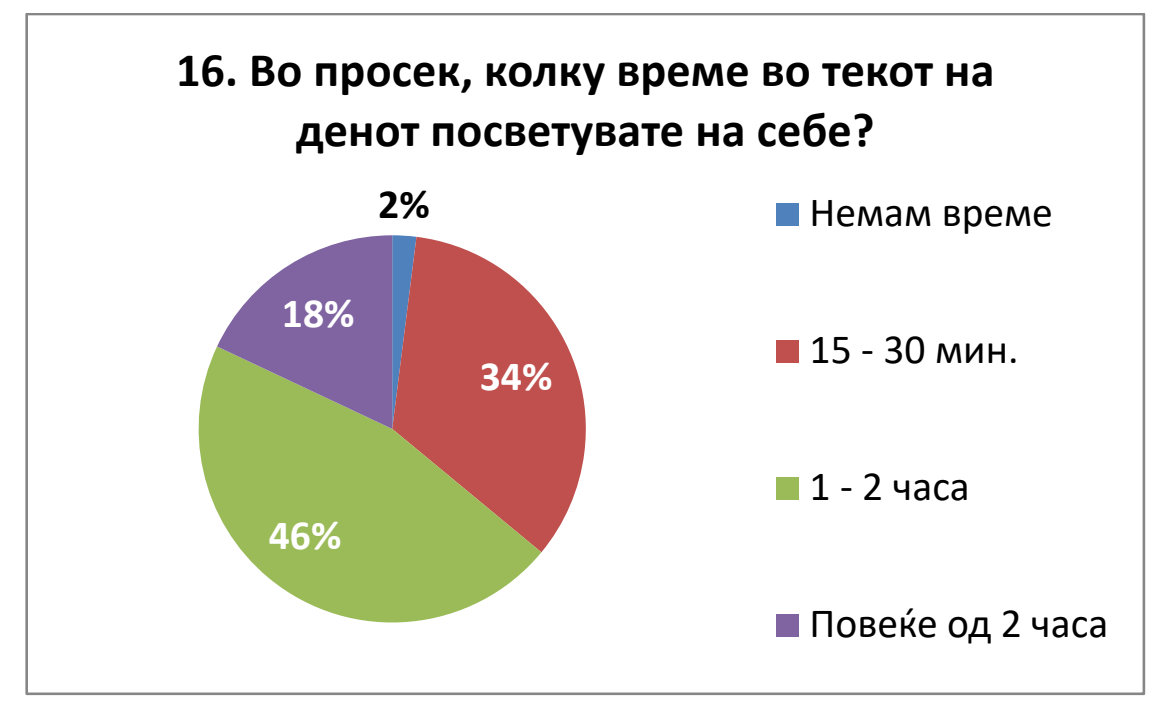

Граф. 3.2-16 Графички приказ на резултатите од прашањето 16 од анкетниот прашалник.

Начинот на одговарање на претходното прашање е поврзан со возрасната категорија, најмладите испитаници како и највозрасните имаат повеќе време во текот на денот за себе, додека средните возрасни категории имаат најмалку време за себе во текот на денот.

На следното прашање, испитаниците одговорија што најчесто прават во нивното слободно време.

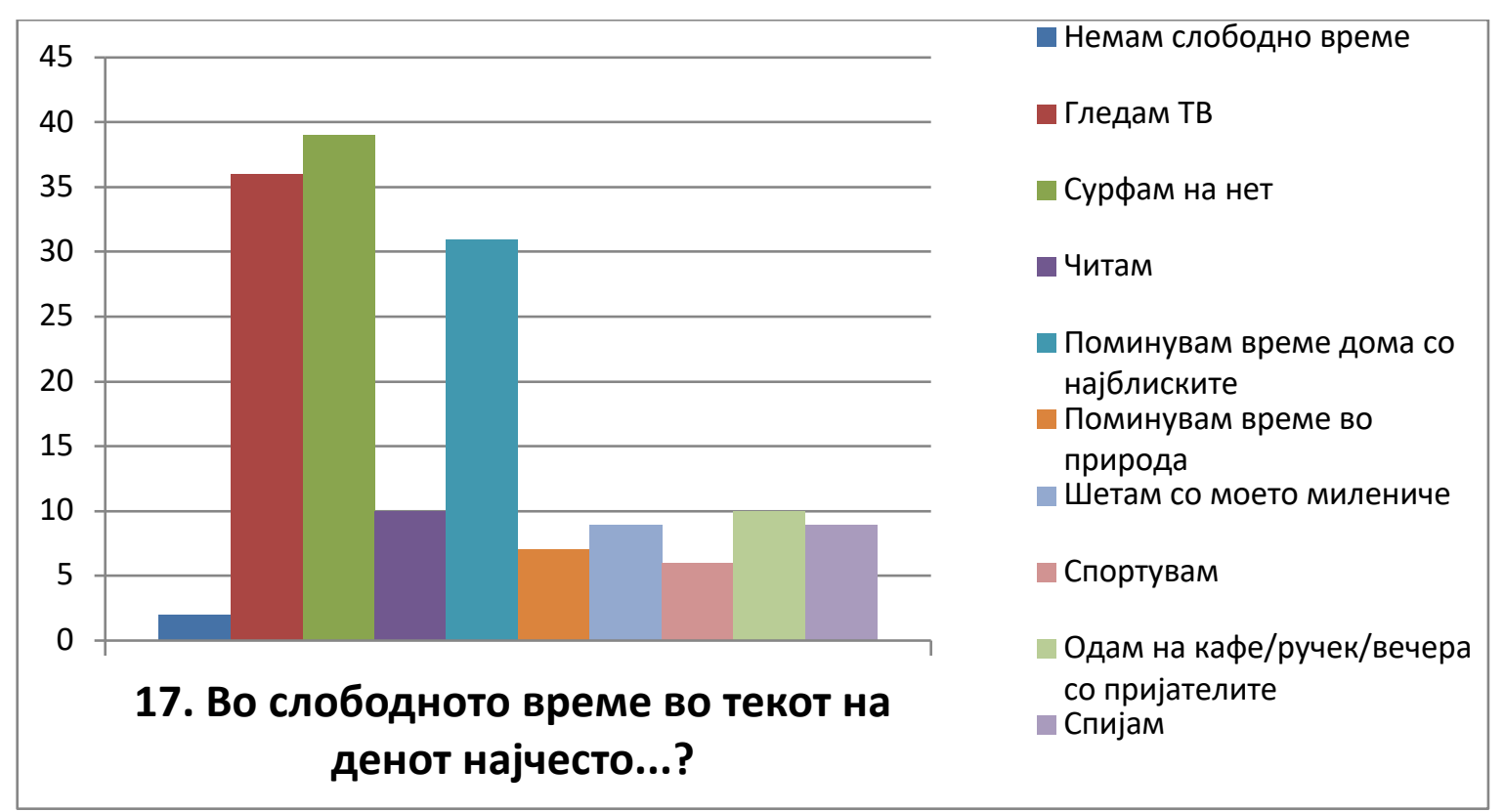

Граф. 3.2-17 Графички приказ на резултатите од прашањето 17 од анкетниот прашалник.

Од анализата е видливо дека како одговори отскокнуваат - поминувањето време дома, гледањето ТВ и сурфањето на интернет. Без разлика на возрасната категорија на која припаѓаат, испитаниците главно ги вршат тие активности, а малкумина го поминуваат слободното време правејќи нешта како физичка активност, 
поминување време во природа или социјализирање кои би го редуцирале стресот и би го стимулирале размислувањето и градењето на позитивен став.

На прашањето дали животот во Скопје претставува стрес поради гужвите, градењето, сообраќајниот метеж, навиките на луѓето и сл., или пак истиот претставува задоволство, никој не дал одговор дека ужива во животот во Скопје, на најголемиот дел од испитаниците начинот на живот во Скопје им влијае врз зголемување на стресот, додека останатите не мислат дека им го зголемува стресот поради тоа што се навикнати да не реагираат на дразбите од околината.

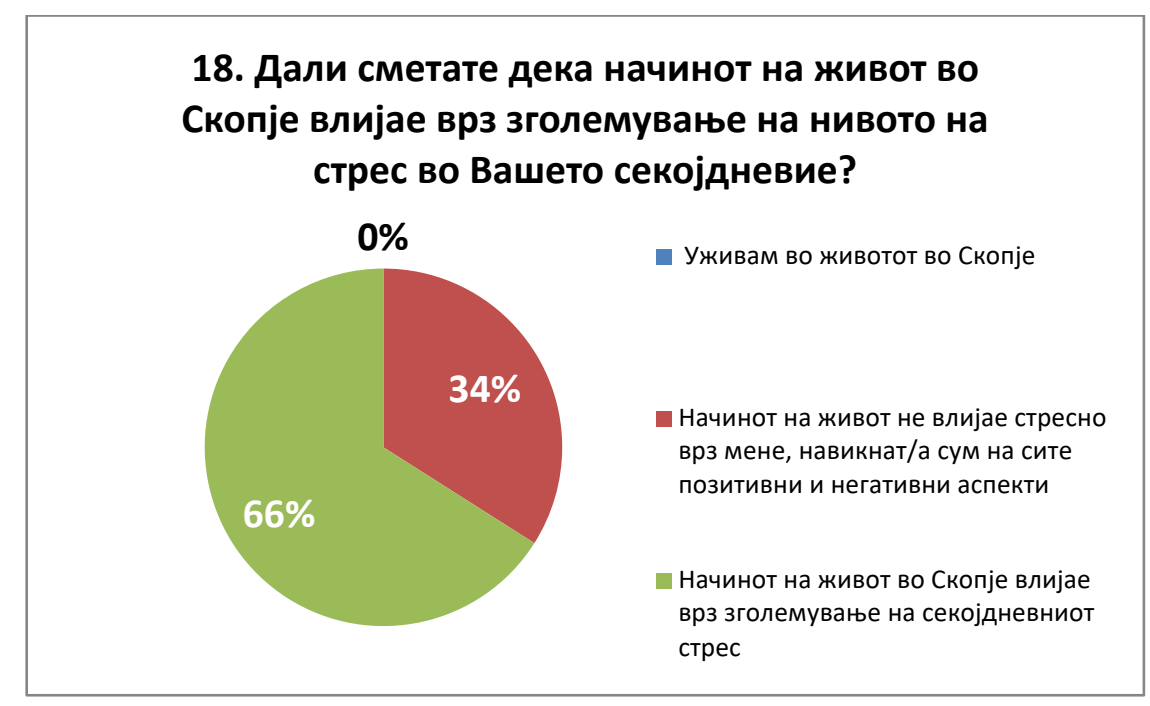

Граф. 3.2-18 Графички приказ на резултатите од прашањето 18 од анкетниот прашалник.

Во однос на прашањето дали во Скопје има доволно урбани катчиња за поминување на слободното време (не земајќи ги во предвид кафулињата и рестораните) повеќето од испитаниците сметаат дека нема, а сметаат дека доколку би имало би поминувале време во нив за вршење на различни активности и за одмор. Интересно е тоа што дел од испитаниците на овие прашања одговориле со - не знам што алудира на тоа дека не се запознаени како всушност изгледаат вакви урбани катчиња, што би очекувале да има во нив и како би ги користеле. 

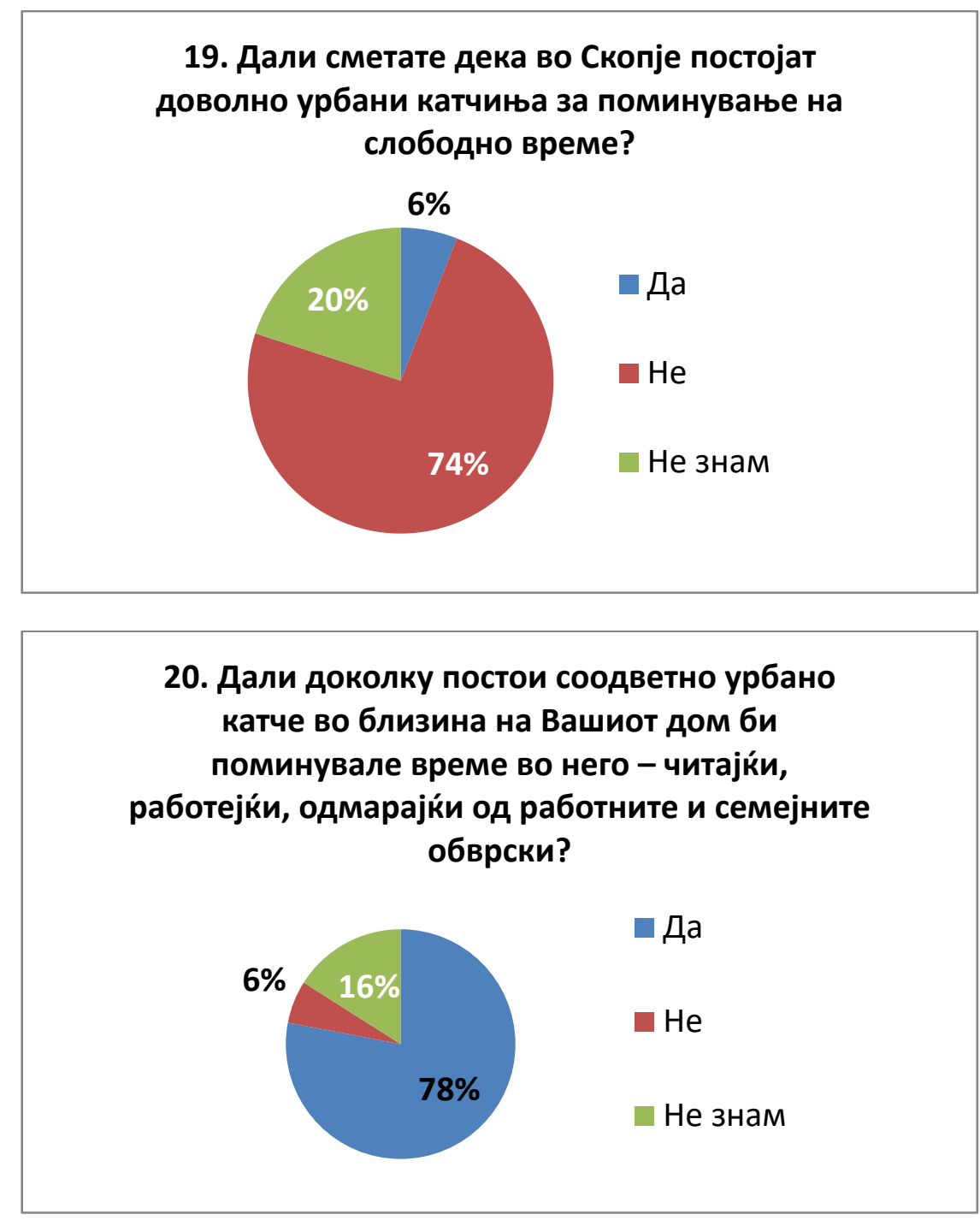

Граф. 3.2-19,20 Графички приказ на резултатите од прашањата 19 и 20 од анкетниот прашалник.

Испитаниците кои одговорија дека би сакале да поминуваат време во такво урбано катче, понатаму одговорија на уште едно дополнително прашање преку кое се дознава што би сакале едно вакво место да содржи за да уживаат во него. Резултатите се прикажани подолу. 


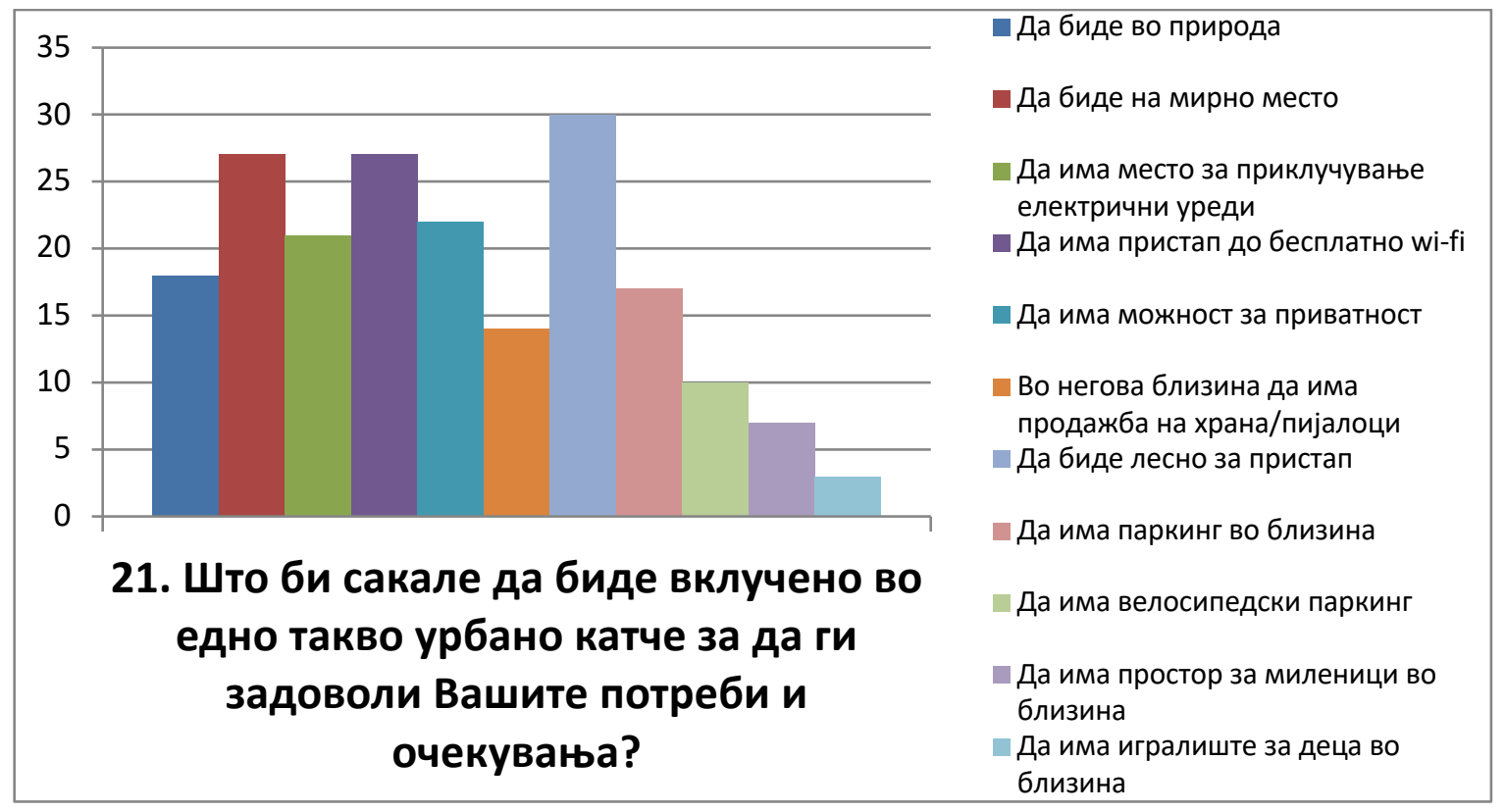

Граф. 3.2-21 Графички приказ на резултатите од прашањето 21 од анкетниот прашалник.

\subsection{1 Заклучок од анализа на анкетен прашалник}

Како кратки, генерални заклучоци од оваа анкета може да се издвојат следниве нешта:

- Возрасните, вработени жители на град Скопје имаат потреба од подобро користење на одморот во текот на денот и соодветни активности за редуцирање на стресот и стимулирање на креативноста

- Тие имаат потреба од простор каде ќе може да ги вршат овие активности за време на паузите во текот на работниот ден како и во приватното слободно време

- Тие најмногу би сакале тој простор да ги има следните карактеристики:

$>$ Да биде на мирно место

$>$ Да има обезбедено места за приклучување на електрични уреди

$>$ Да има пристап до бесплатно wi-fi

$>$ Да овозможува приватност

$>$ Да биде лесно за пристап и употреба 


\section{4. ДЕФИНИРАЊЕ НА ДИЗАЈНЕРСКИ ПРОБЛЕМ ЗА ПРИМЕНА НА ПРОЧУЕНИТЕ ПРИНЦИПИ}

Изведените заклучоци од спроведената анализа преку набљудување и испитување се индикатори дека во град Скопје постои проблемот на немање соодветен урбан простор каде луѓето би можеле да вршат секојдневни активности кои придонесуваат за одржување и подобрување на нивното ментално здравје. Овој проблем, доколку остане занемарен, со текот на времето би еволуирал во уште покомплексна општествена ситуација - општество кое не може да напредува поради тоа што неговите жители се масовно потпаднати под влијание на урбаниот стрес, раздразнети, склони кон депресија, неспособни за воспоставување на позитивни релации и со значително намалена креативност и продуктивност.

\section{1. СОГЛЕДУВАЊЕ НА ПОТРЕБА - ИДЕЈА ЗА ПРОИЗВОД}

Сите спроведени истражувања резултираа со идеја за дизајнирање на производ кој ќе помогне во решавање на дефинираниот проблем - урбан павиљон.

Поимот павиљон може да има повеќе значења, но генерално, во архитектурата под павиљон се подразбира дополнителен објект кој е поставен независно или во склоп на главната зграда и е нејзино надополнување на некој начин. Неговата функција е да биде простор за лично задоволство без разлика дали неговата улога ја исполнува како простор за спортска активност, за приготвување на храна, летниковец во градина, простор за игри, за изложби или работилници, за читање, за работа, за релаксација итн. Павиљонот е флексибилен, отворен простор со својства кои ги привлекуваат луѓето да посакаат да поминуваат време во него.

Во оваа магистерска работа идејата за павиљонот е тој да биде дизајниран како урбано катче кое ќе претставува извор на позитивни емоции за граѓаните и ќе го надополни оној дефицит на соодветен простор за поминување на слободното време. Овој павиљон како производ би требало да претставува простор, односно објект, кој може да се инкорпорира на повеќе локации во градот, каде што има можност. Исто така, компаниите би можеле да го поставуваат како додатен простор, надвор од нивниот главен објект, наменет за употреба од страна на вработените кои би можеле да дојдат во него за да се оттргнат од динамичното опкружување. Овој павиљон е замислен како место каде граѓаните би можеле да поминуваат време сами или во друштво, да се напијат кафе или да јадат, да читаат книги, весници и списанија, да работат на својот компјутер, да имаат опуштен работен состанок или едноставно да одвојат неколку минути за индивидуална релаксација. Ваквиот начин на функционирање на павиљонот би овозможил редуцирање на стресот кој го носи секојдневието во животот на луѓето. Токму затоа, павиљонот мора да биде креиран следејќи ги принципите на позитивен дизајн - зелени површини, активни зони, про- 
социјални места, безбедни места. Дополнително, овој павиљон и сите елементи кои ќе ги вклучува - структура, фасада, внатрешност, клупи, маси, приклучоци за електронски уреди и сл. - треба да се еколошки и да не го загрозуваат и нарушуваат функционирањето на околниот еко систем.

\section{5. АНАЛИЗА НА ПОСТОЕЧКИ ПРИМЕРИ}

Со цел креирање на успешен дизајн, направена е анализа на веќе постоечки урбани павиљони кои соодветствуваат на дефинираните барања на таргет групата и помагаат во решавање на проблемот со недостаток на урбан простор за одмор, дружење, црпење инспирација, подобрување на концентрацијата и генерално зголемување на позитивното размислување. Издвоени се добри примери на урбани павиљони и дополнителна урбана опрема од повеќе градови низ светот, како и во Скопје, со главна намера да се извлечат нивните клучни позитивни карактеристики и истите да бидат водилка при генерирањето на концептни решенија.

\section{1 УРБАНИЗАМ НИЗ СВЕТОТ}

\section{„The Duplantier Volunteer Pavilion" - Њу Орлеанс, САД [36]}

Овој павиљон е лоциран во ботаничката градина во гратскиот парк на Њу Орлеанс и е замислен во вид на 6 идентични модули кои се групирани или одделени еден од друг со цел да се адаптираат на условите на теренот - дрвјата, корените, ограничувањата на локацијата. Одлично ја употребува локалната природна површина без да го попречи нејзиното функционирање. Формиран од дрвени сегменти идентични во големина и форма поставени на челична носечка конструкција, овој павиљон креира шеми на светлина и сенка во текот на денот, дозволувајќи проток на воздух и поглед на околната природа што го прави одличен за релаксација и поврзување со природата.
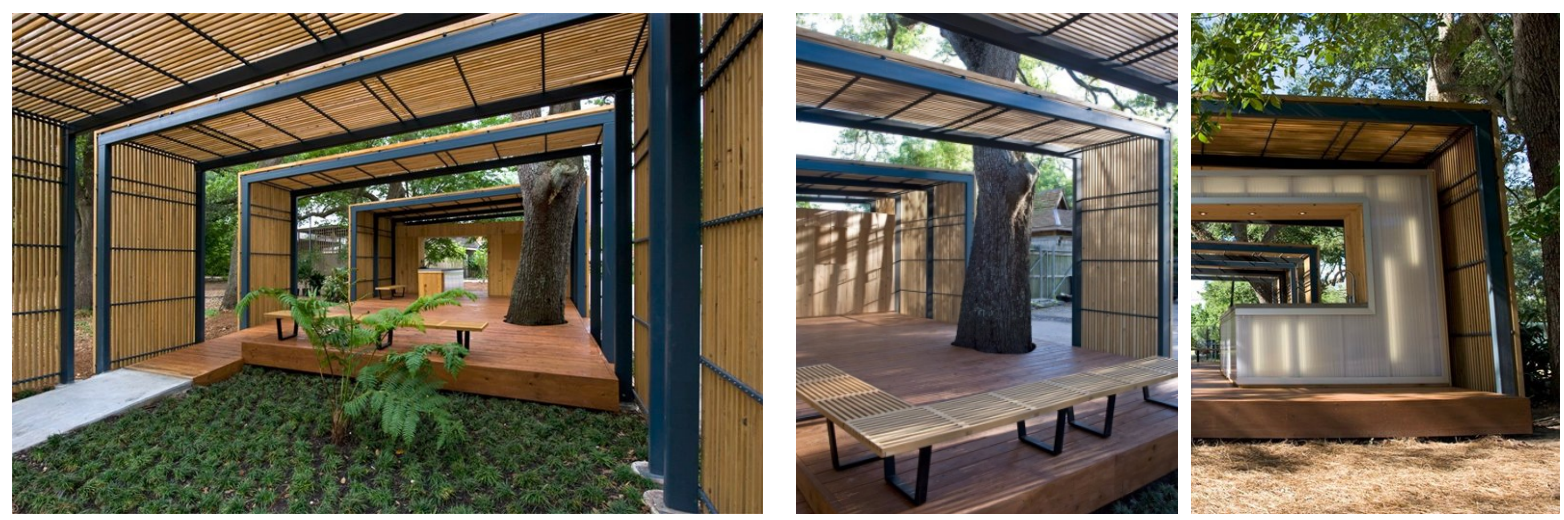

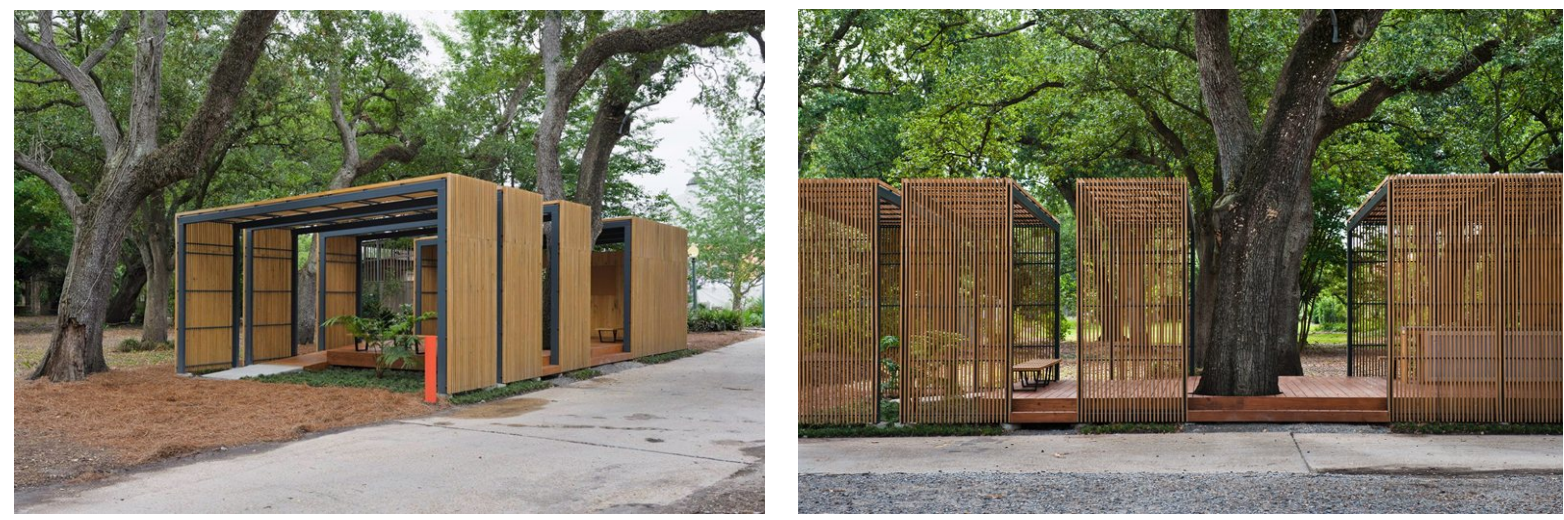

Сл.5.1- 1,2,3,4,5 „The Duplantier Volunteer Pavilion“ - Њу Орлеанс, САД.

\section{ПОЗИТИВНИ КАРАКТЕРИСТИКИ}

$>$ Лоциран е во парк што овозможува врска со природна средина и зеленило кое ја стимулира релаксацијата и креативното размислување

$>$ Има клупи за одмор

> Претставува јавно место кое поттикнува спонтана социјална интеракција

> Претставува место кое може да се користи како индивидуално катче за одвојување време за себе, размислување, читање и сл., но може да служи и како катче за дружба меѓу пријатели или колеги

> Еколошко е поради еко материјалите од кои е изработена конструкцијата, но и поради тоа што е изградено на начин што не го попречува локалниот еко систем

\section{„Tiny timber meditation pavilion" - Стелвио, Иmaлиja [37]}

Лоциран во националниот парк Стелвио во Италија, овој мал дрвен павиљон за медитација е дизајниран со цел да ги охрабри луѓето на тивка интроспекција во природа. Само неколку луѓе може да влезат во дрвениот павиљон во исто време, да се одморат на дрвените гранки и да уживаат во погледот на езеро.
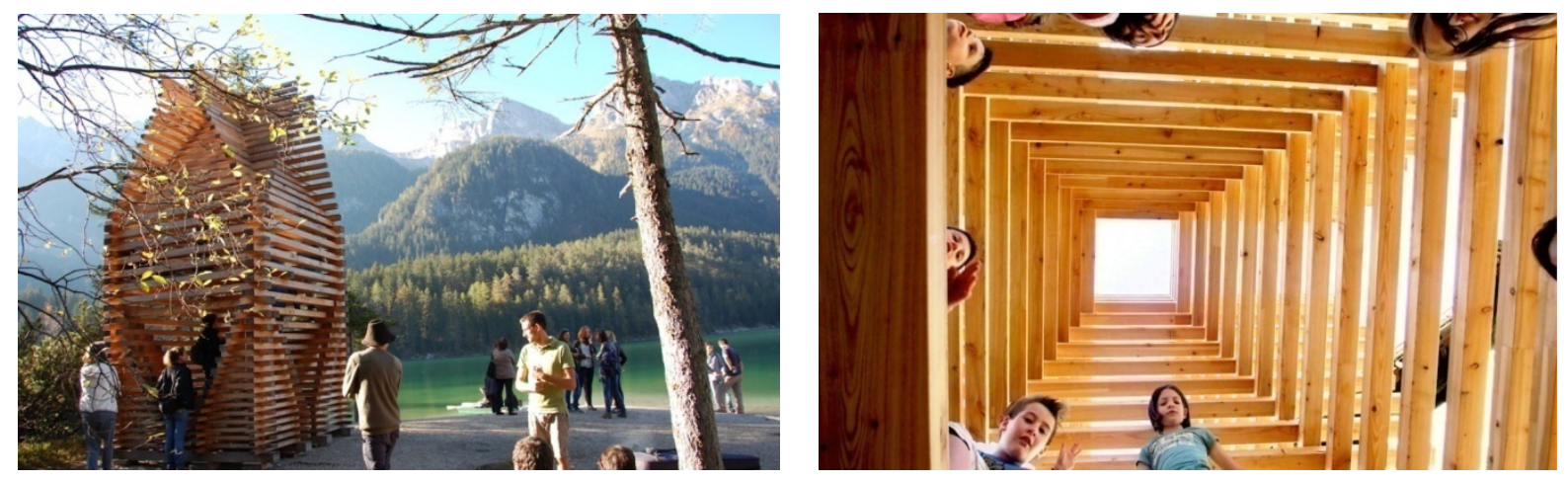

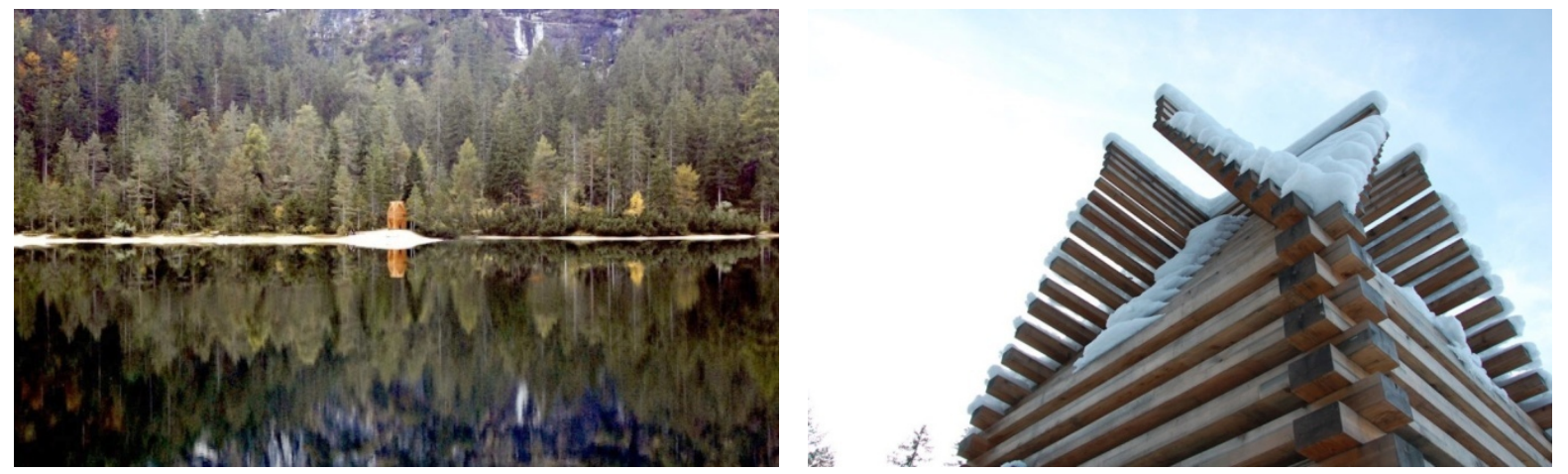

Сл.5.1- 6,7,8,9 „Tiny timber meditation pavilion“ - Стелвио, Италија.

\section{ПОЗИТИВНИ КАРАКТЕРИСТИКИ}

$>$ Лоциран е во природна средина, покрај шума и езеро што овозможува зголемен квалитет психичкиот одмор

$>$ Нуди одлична можност за релаксација и медитација поради конструкцијата која овозможува приватност

$>$ Изработено е од еколошки материјали и претставува единство со природната средина во која се наоѓa

\section{„Sharon Fieldhouse “ - Вирчинија, САД [38]}

Група на студенти на Универзитетот Virginia Tech го дизајнирале овој јавен павиљон кој е наменет за учење или социјализирање на студентите. Павиљонот е конструиран во три дела на начин кој дозволува екстериерот да стане дел од ентериерот. Павиљонот е дизајниран со идејата да претставува единство со природата и да користи природни системи за греење и ладење кои ќе овозможат употреба на павиљонот во повеќе сезони.
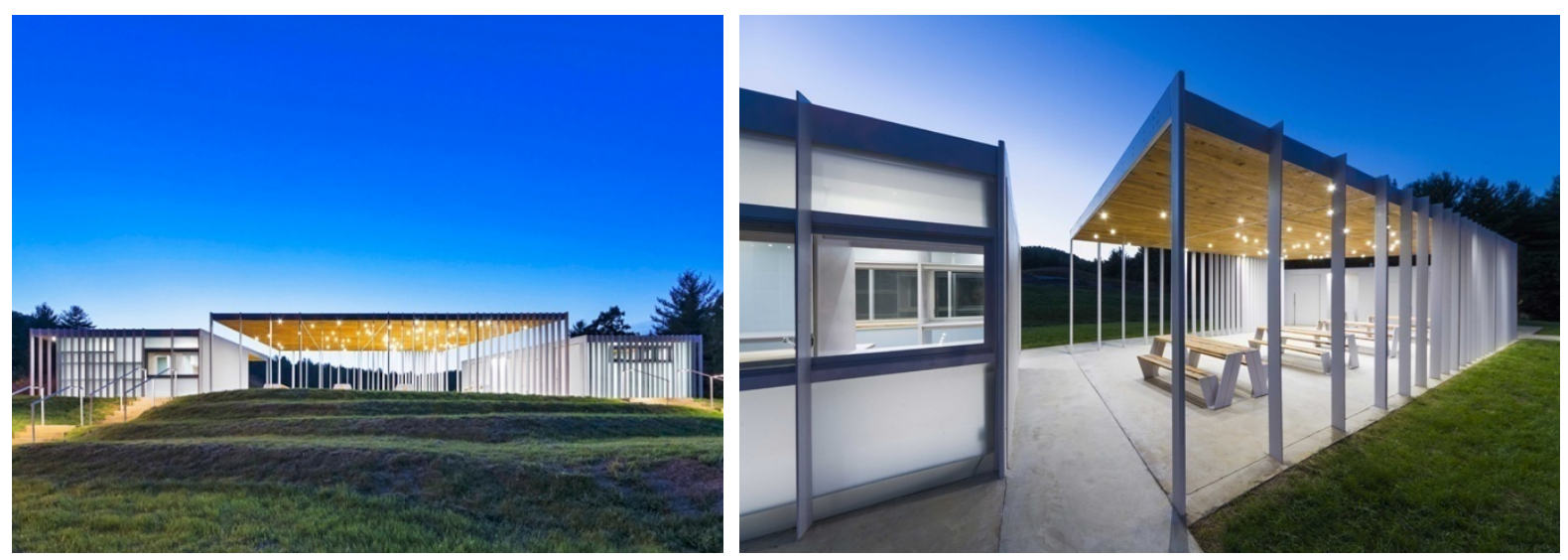

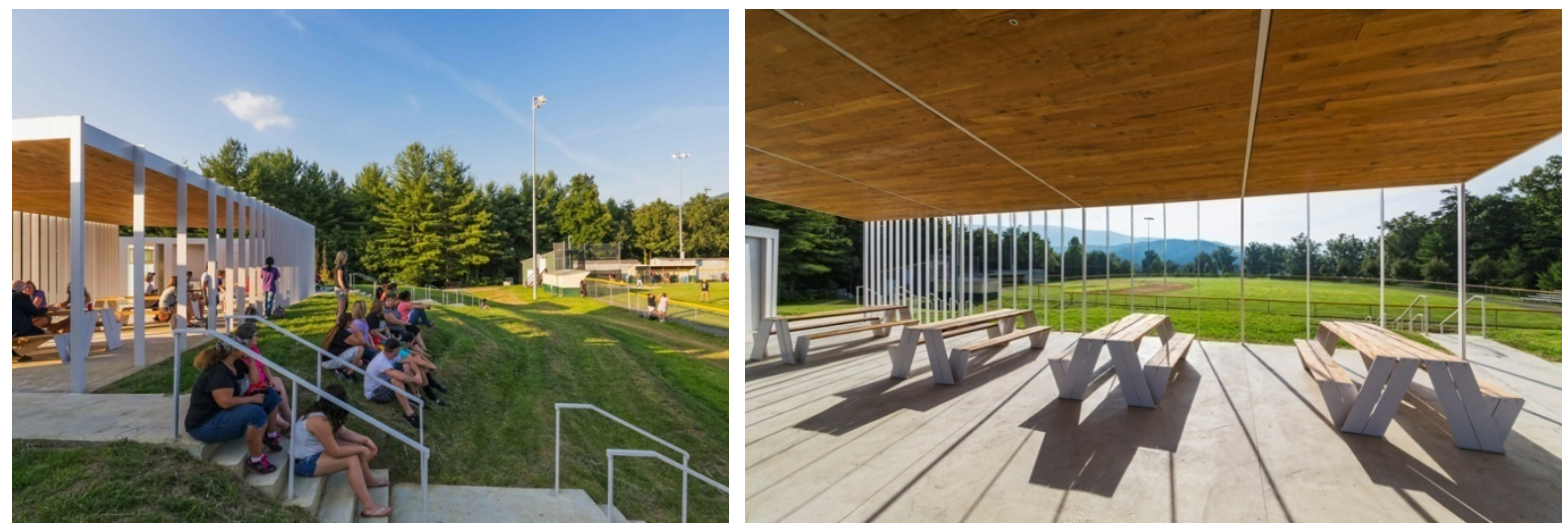

Сл.5.1- 10,11,12,13 „Sharon Fieldhouse “ - Вирцинија, САД.

\begin{tabular}{l}
\hline \multicolumn{1}{c}{ ПОЗИТИВНИ КАРАКТЕРИСТИКИ } \\
\hline$>$ \\
Лоциран е во природна средина (парк) што значи стимулирање на \\
размслувањето и помнењето \\
Бројните клупи, скалила и скалести тревници нудат можност за социјална \\
интеракциа, дружење \\
$>$ Клупите со масички служат за читање, пишување, работа на лаптоп \\
$>$ Исто така, на овие клупи е можно и групно работење, дискусии, \\
брејнсторминг \\
$>$ \\
Убавиот поглед кон природа и бројните места за седење се одлични за \\
индивидуална релаксација \\
$>$ Тревниците, пак, се одлични за одмор и пикник
\end{tabular}

\section{„MPavilion“ - Мелбурн, Австралија [39]}

Креаторите на овој летен амфитеатар лоциран во Мелбурн велат дека неговата намена е да поттикне организација на различни настани и останати социјални собири. Опкружен е со вештачки рид околу кој се насадени локални растенија и има транспарентен покрив со вградена напредна технологија на осветлување од внатрешниот дел, а од страните амфитеатарот е отворен кон околниот парк.
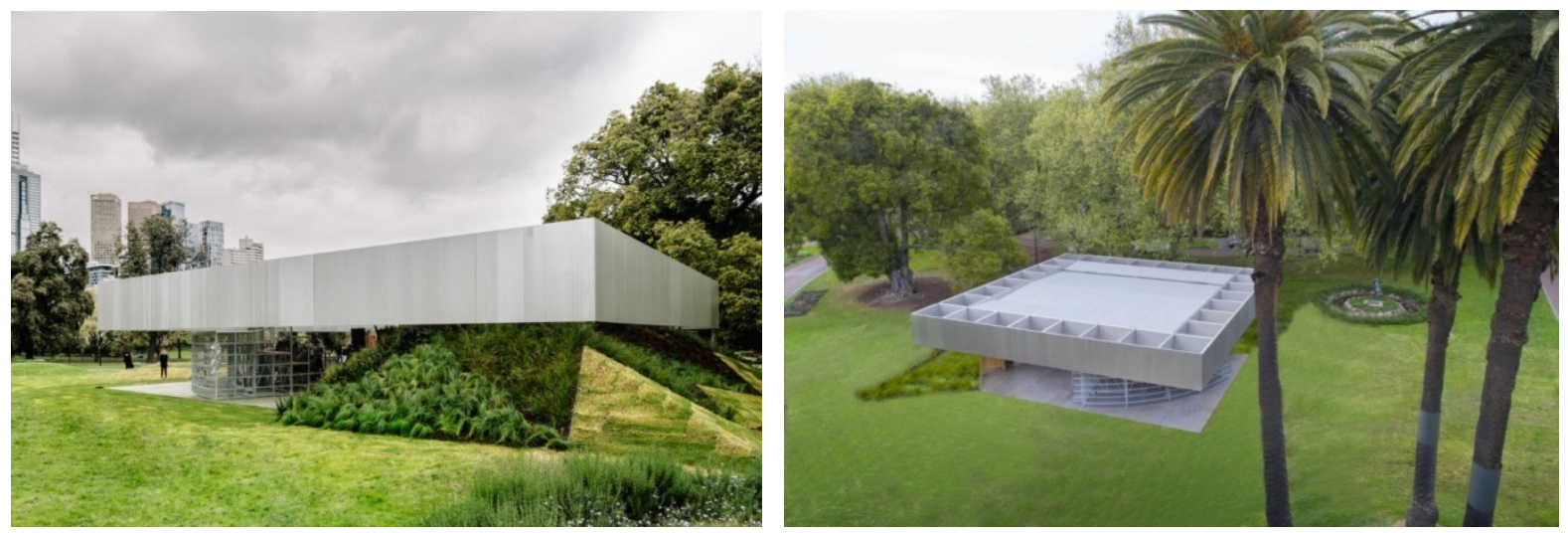

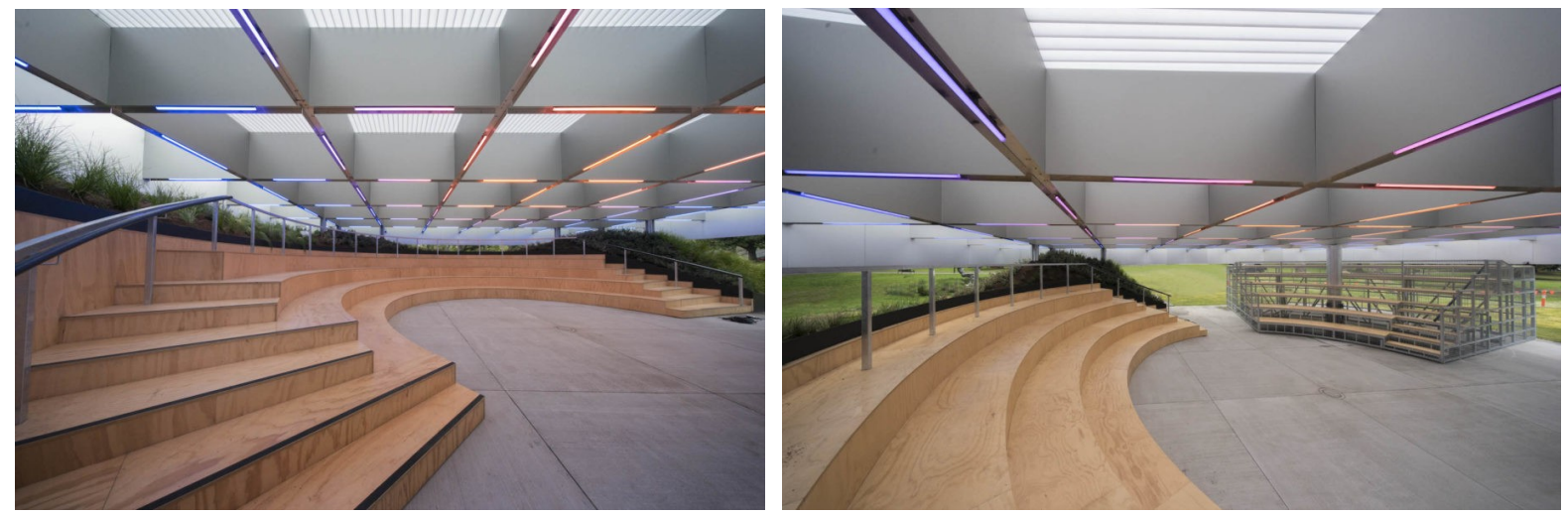

Cл.5.1- 14,15,16,17 „MPavilion“ - Мелбурн, Австралија.

ПОЗИТИВНИ КАРАКТЕРИСТИКИ

$>$ Лоциран е во парк, на отворено, што овозможува привремено оттргање од градскиот метеж и одмор

$>$ Неговата големина и амфитеатарот се одлични за спонтана социјална интеракција меѓу случајни минувачи или пријатели

$>$ Амфитеатарот е исто така одличен за одржување на предавања, дискусии, работилници и сл.

\section{„Serpentine Pavilion “ - Лондон, Англија [40]}

Овој павиљон е карактеристичен не само по уникатниот дизајн, туку и по неговата иновативна функција на складирање вода. Иако изгледа подеднакво убаво и може да се употребува и во сончеви и во облачни денови, кога надвор е дождливо, покрај тоа што служи како натстрешница и простор за одмор на минувачите, истиот ги складира капките дожд, а складираната вода потоа се употребува за наводнување на паркот во кој се наоѓа павиљонот. Идејата на креаторот на овој павиљон е да истиот да им овозможи на жителите да бидат заштитени од дождот, но истовремено да можат да уживаат во убавината на природните појави, движењето на облаците, ветерот и капките дожд кои се гледаат низ транспарентниот покрив.
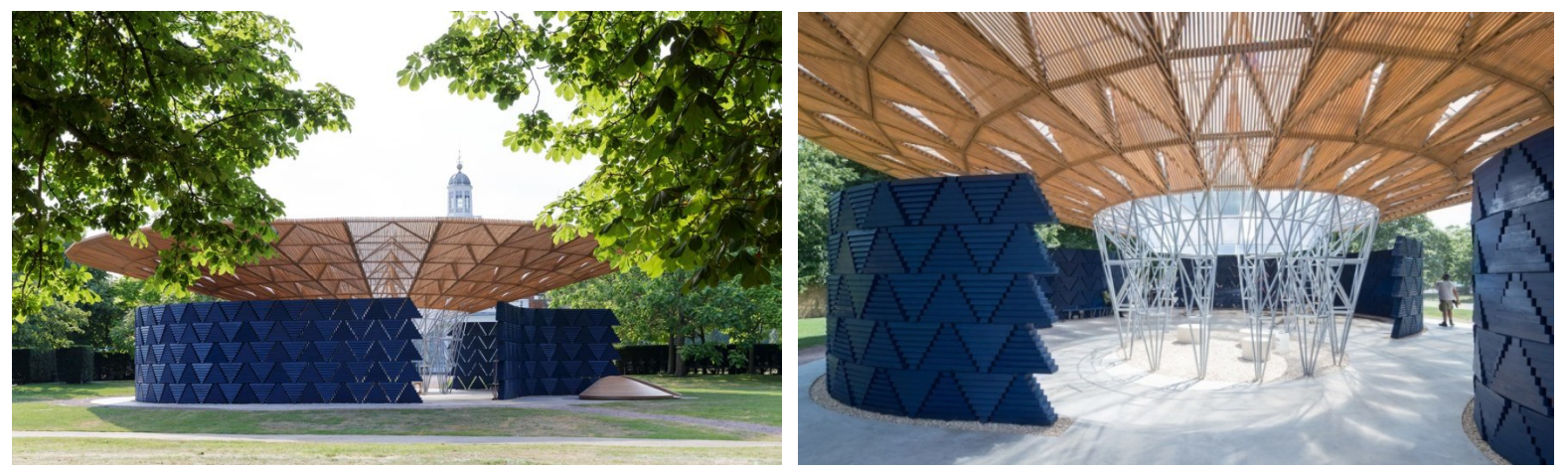

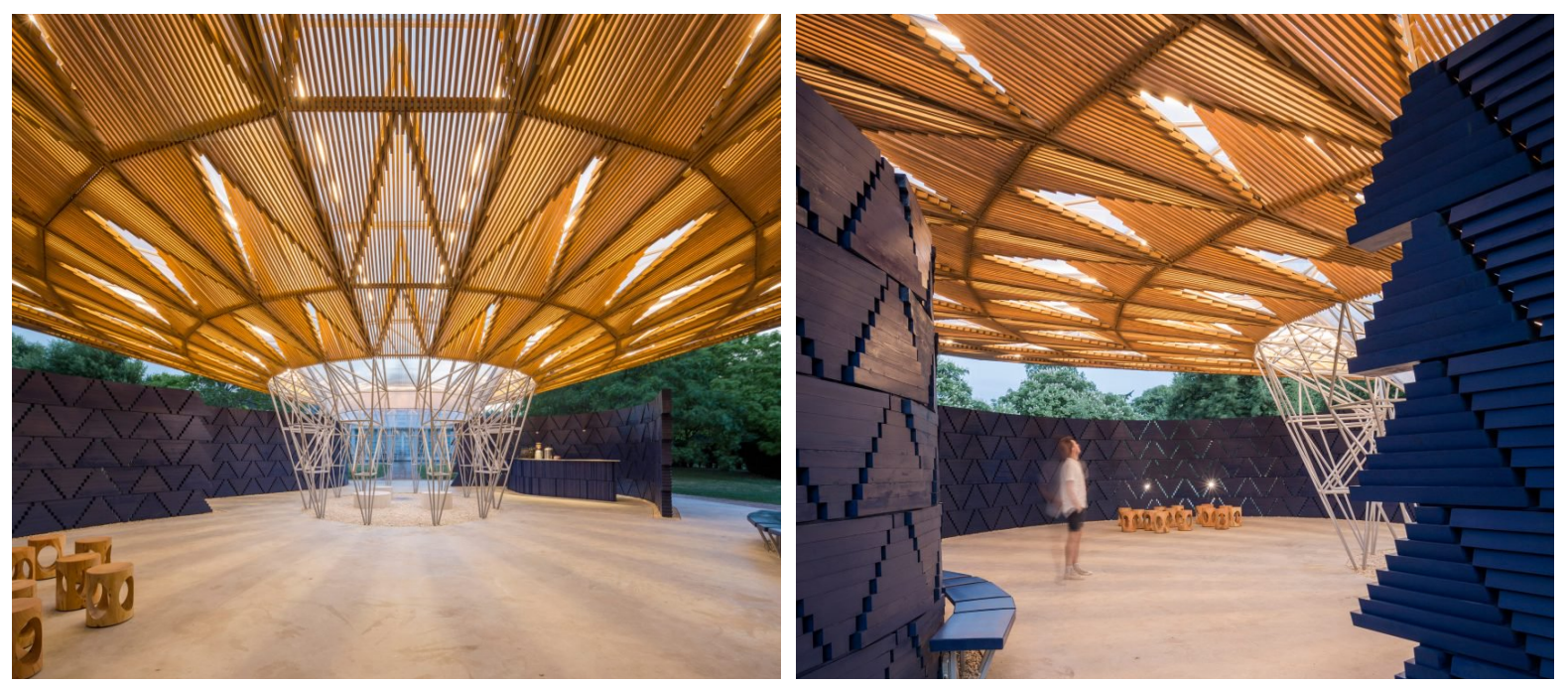

Сл.5.1- 18,19,20,21 „Serpentine Pavilion “ - Лондон, Англија.

\section{ПОЗИТИВНИ КАРАКТЕРИСТИКИ}

$>$ Лоциран е во парк, на отворено, што овозможува привремено оттргање од градскиот метеж

$>$ Нуди можност за поинакво доживување на убавината на секојдневните природни појави кои луѓето вообичаено речиси и не ги перцепираат, а тоа значи поврзување со природата, психички одмор, стимулирање на креативноста

$>$ Дизајнот е еколошки, според конструкцијата и функцијата на складирање на вода за наводнување на паркот

\section{„Pavillon Martell“ - Коњак, Франција [41]}

Оваа „урбана транспарентна шума“ лоцирана во Франција е конструирана од полиестер засилен со стаклени влакна формиран во урбан павиљон главно наменет за релаксација и забава на жителите, како и оддржување на разни видови на работилници. Седиштата на надувување нудат можност за опуштање, светлината преминува низ транспарентните површини на конструкцијата и на моменти создава ефект на виножито, а леснотијата на материјалите отвара можност за дислоцирање на целиот павиљон и негово поставуање на различни локации во градот.
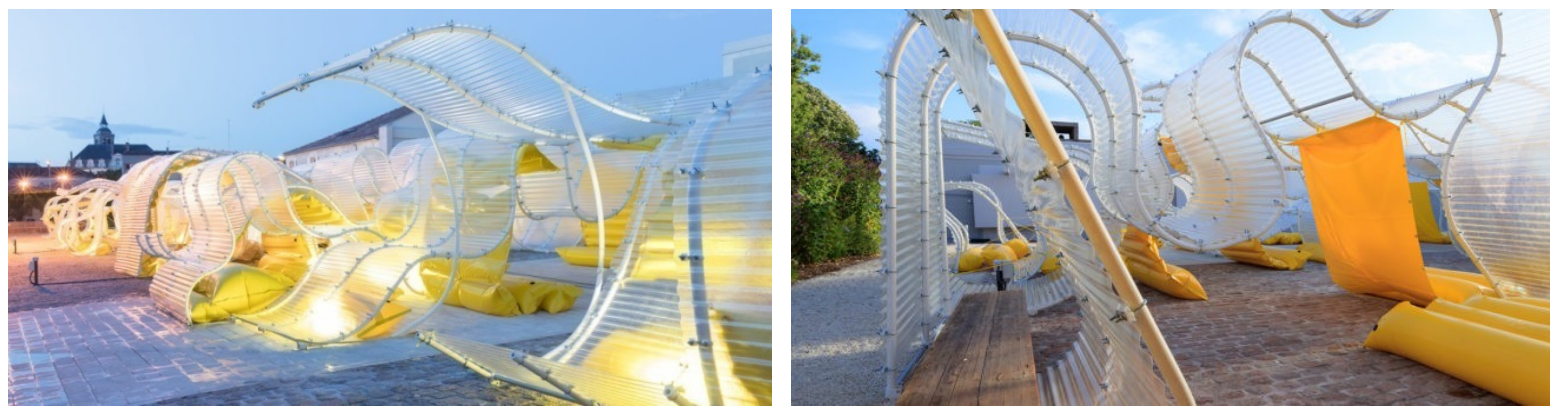

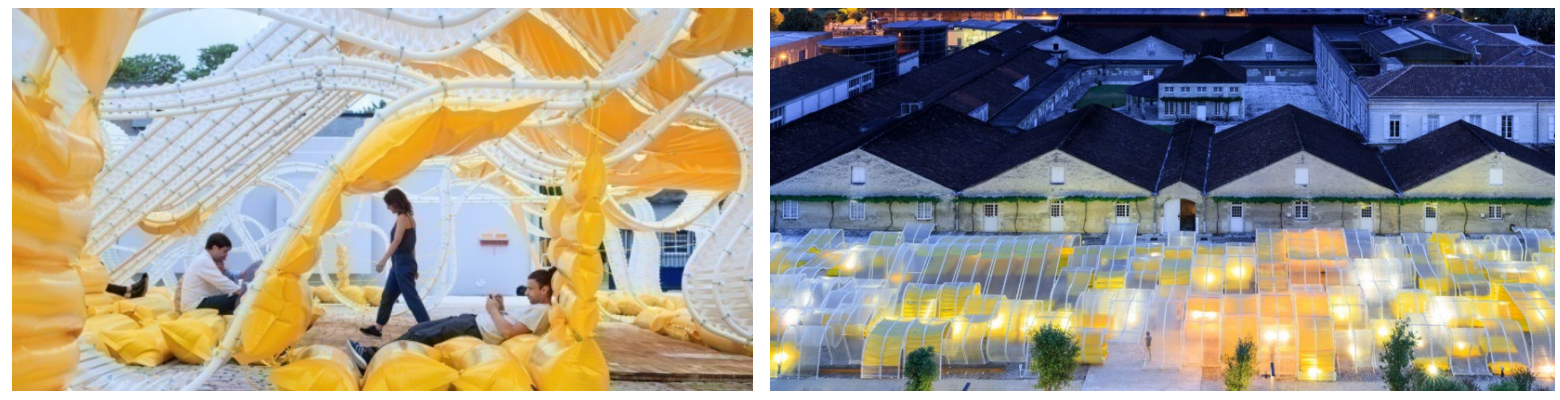

Сл.5.1- 22,23,24,25 „Pavillon Martell“ - Коњак, Франција.

\section{ПОЗИТИВНИ КАРАКТЕРИСТИКИ}

$>$ Буди позитивни чувтсва кај жителите бидејќи дизајнот е невообичаен и забавен

$>$ Удобните фотелји овозможуваат индивидуална релаксација од напорното секојдневие, слушање музика, читање, сурфање на интернет и сл.

$>$ Бидејќи фотелјите се одвоени, местото е одлично за овозможена приватност

$>$ Споените клупи и близината на фотелјите нудат можност и за социјална интеракција и дружба

$>$ Може да се употребува и за настани и работилници од различен тип

\section{„Walkway Nests" - Езеро Paprocany, Полска [42]}

Овој павиљон претставува иновативен дизајн на шеталиште покрај езеро кој им овозможува на жителите поинаков поглед на околината. Покрај дрвените клупи, чадори за заштита од сонце и вечерно осветлување, павиљонот нуди можност за релаксација преку поставените мрежи кои се фиксирани на дрвени рамки над водната површина дозволувајќи им на минувачите да легнат на нив и да уживаат во амбиентот.
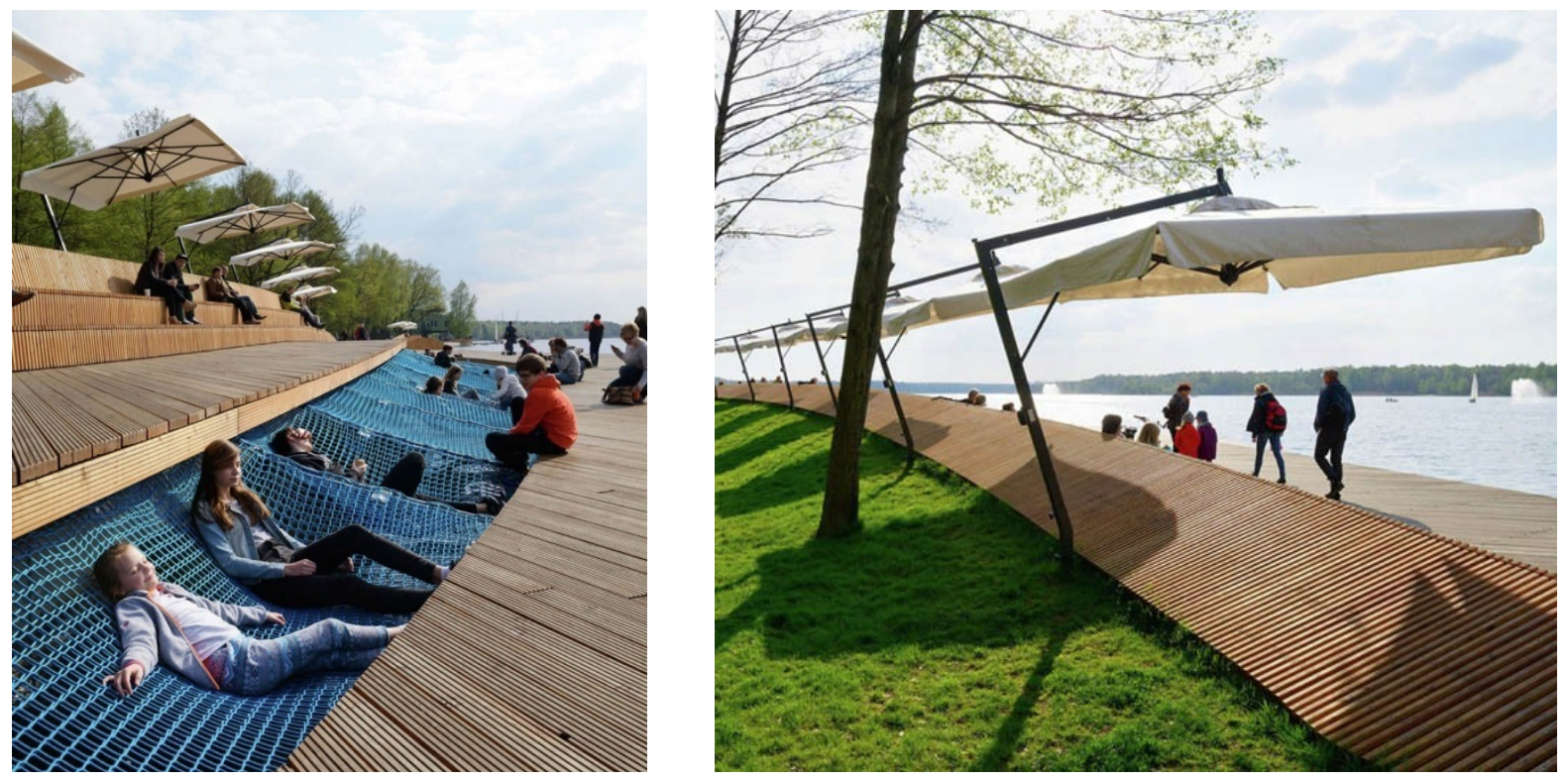

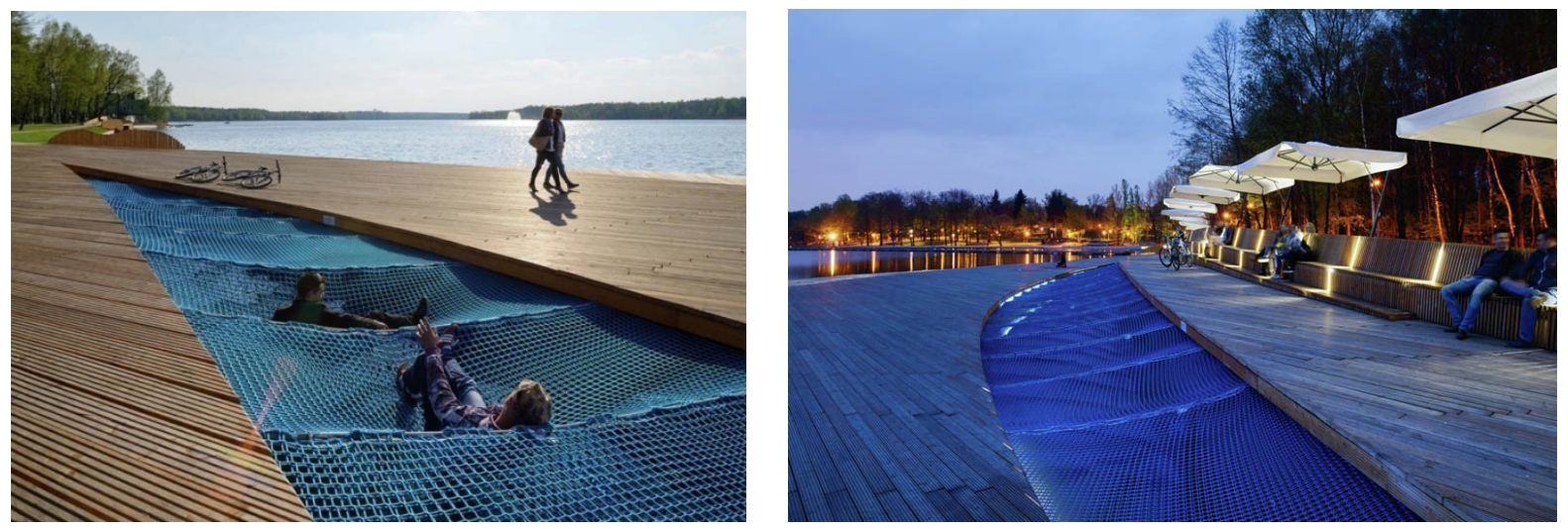

Сл.5.1- 26,27,28,29 „Walkway Nests" - Езеро Paprocany, Полска.

\section{ПОЗИТИВНИ КАРАКТЕРИСТИКИ}

$>$ Лоциран е покрај водна површина, идеален за одмор и релаксација во текот на денот

$>$ Бројните споени клупи овозможуваат спонтана социјална интеракција

$>$ Истовремено клупите се соодветни и за индивидуална употреба

$>$ Мрежите се невообичаени и забавни и побудуваат позитивни чувства како и поинаков поглед врз околината и зголемено уживање

\section{„Digital Break “- Париз, Франција [43]}

Ова модерно, урбано катче нуди можност за краток одмор и разбивање на монотонијата на динамичното секојдневие. Конструкцијата е еколошка, со зелен покрив и има модерен и привлечен дизајн. Нуди брзо ви-фи, мултимедијален екран со мапи од градот и локални вести како и удобни седишта со мала масичка и полначи за електронски уреди, а погледот кон парк и фонтана го зголемува пријатното чувство во просторот. Овој мал павиљон претставува одличен пример за урбано катче кое може да се постави на многу локации низ градот и да им понуди на луѓето можност за оттргнување од стандардните канцелариски простории за работа и пауза.
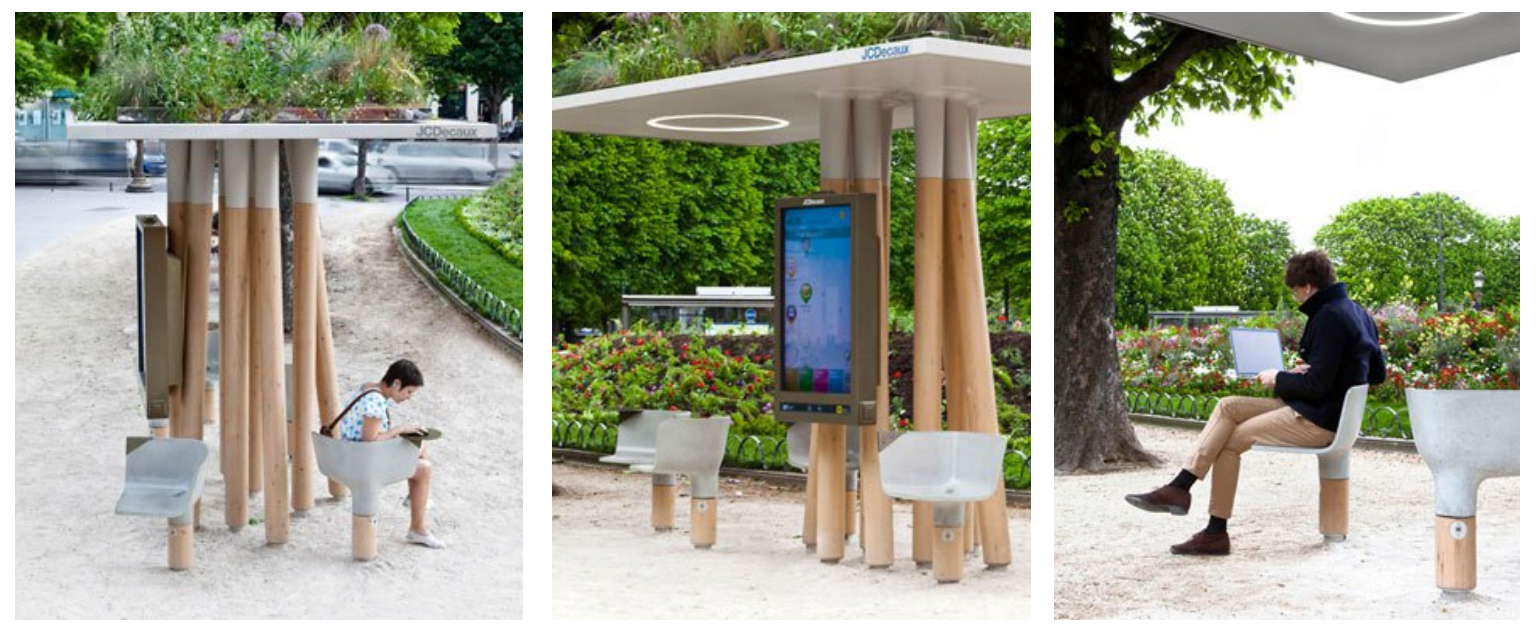

Cл.5.1- 30,31,32 „Digital Break “- Париз, Франција. 
$>$ Има компактен дизајн кој може да се поставува на бројни локации во градот

> Има еколошки дизајн, со зелен покрив за прочистување на воздухот

$>$ Има поглед кон уредено паркче што помага за релаксација и поттикнување на креативноста

> Нуди можност за индивидуална работа преку одделените седишта со масички и полначи за електронски уреди

$>$ Одлично место за поминување на пауза од работа бидејќи луѓето може да се оттргнат од канцеларија, да се напијат кафе или да јадат, истовремено имајќи контрола врз работните обврски или истражувајќи дополнителни информации преку бесплатното ви-фи

\section{2 УРБАНИЗАМ ВО СКОПЈЕ}

Генерално, во Скопје, јавните простори кои функционираат како области за релаксација, спортување и социјална интеракција се урбаните паркови. Вакви урбани паркови има повеќе, на бројни локации низ скопските населби, на поголеми или помали површини и се опремени со различен тип на просторни инсталцаии. Во овој магистерски труд, направена е анализа на најактуелните скопски паркови со цел да се согледа начинот на кој жителите ги употребуваат, нивните позитивни карактеристики, како и она што недостасува, а би го збогатило и подобрило секојдневниот живот.

\section{Градски парк Скопје, Центар [44]}

Градскиот парк е најголемиот парк во Скопје и во земјава, со вкупна површина од 486,000 м $^{2}$ и преставува отворен јавен простор во кој доминира вегетација и водна површина, а неговата главна функција е простор за мир, релаксација и рекреација на жителите. Изобилува со клупи, летниковци, пешачки патеки и просторни инсталации од едукативен и уметнички карактер. Неговата локација е одлична, бидејќ е централна и пристапот до него е лесен и брз, а истовремено ги поврзува Зоолошката градина, кејот покрај реката Вардар, Забавниот парк (кој е во склоп на самиот парк), а е на блиска оддалеченост и од планината Водно. Особено во топлите и сончеви денови во текот на годината, жители од различни возрасти го користат паркот за одмор, престој на отворен простор и повлекување од градскиот метеж - возрасни луѓе доаѓаат за прошетка и дружење, фамилии со своите најмали за поминување време во природа, млади средношколци и студенти за дружба или учење, спортисти за рекреација итн. Дополнително, во Градскиот парк често се оддржуваат настани, изложби и работилници од различен карактер - спортски, уметнички или музички кои се одлични за едукација и социјална интеракција. Се на се, Градскиот парк во Скопје на повеќе начини придонесува кон поквалитетен живот во градот така што го намалува стресот и го подобрува расположението, помага за подобар развој на децата како и оддржување на виталноста кај повозрасните и има значење во развој на биофилијата (поврзувањето со природата) - односно, паркот влијае врз подобрување на менталното и физичкото здравје на жителите на град Скопје. Но, и покрај сите бенефиции кои ги носи овој парк, сепак тука се проблемите со загадувањето, безбедноста и недостатокот на дополнителни придружни објекти. Дополнително, 
паркот речиси замрува во зимските денови бидејќ нема простор за засолнување од лошите временски услови.
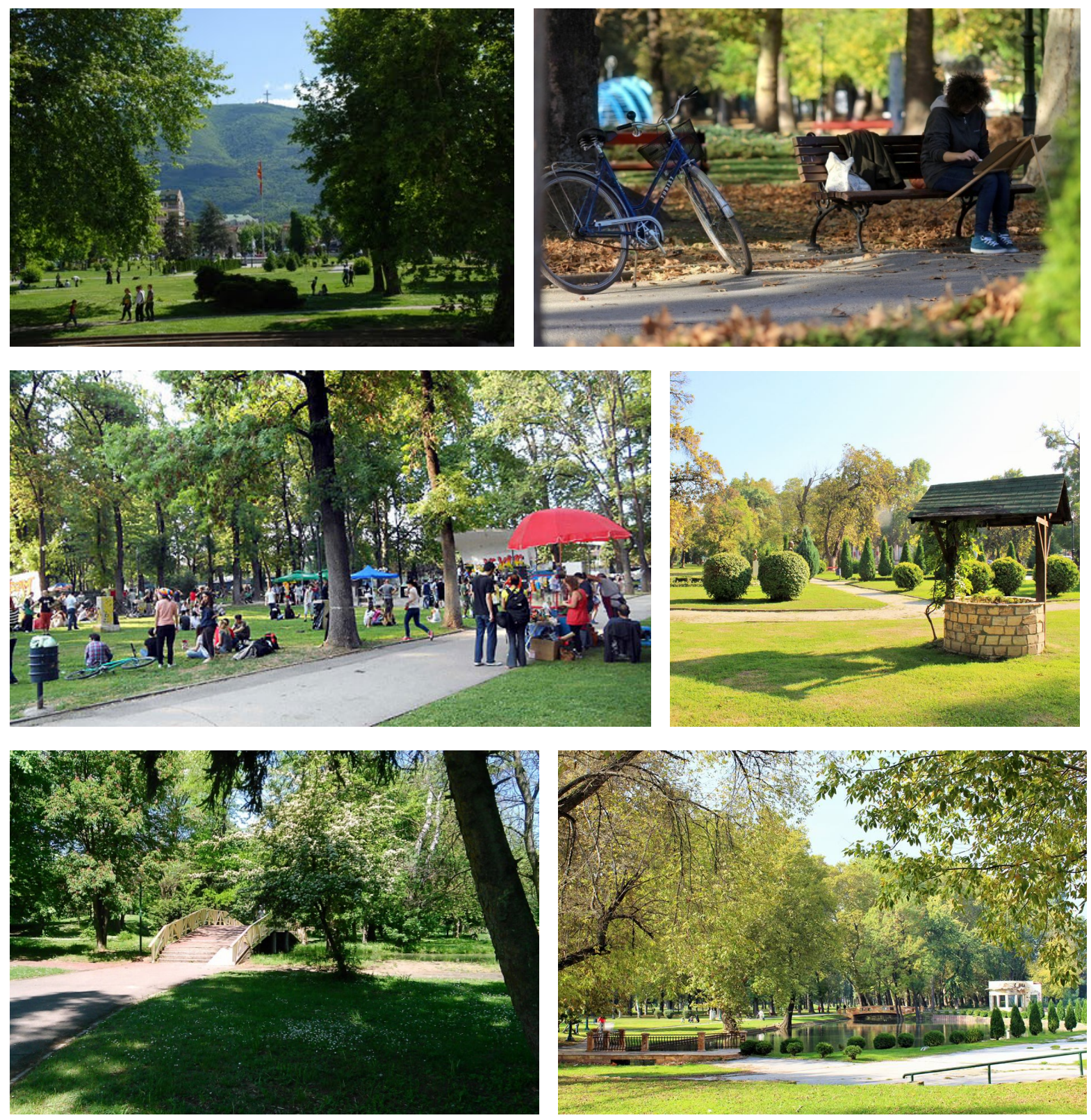

Сл.5.2-1,2,3,4,5,6 Градски парк Скопје, Центар.

ПОЗИТИВНИ КАРАКТЕРИСТИКИ

$>$ Има голема природна површина која овозможува биофилен развој, ја стимулира релаксацијата и поттикнувањето на креативното размислување

$>$ Има бројни шеталишта идеални за физичка рекреација

$>$ Има бројни клупи за одмор и спонтана социјална интеракција

$>$ Овозможува интроспекција и индивидуална релаксација

> Нуди можности за организирање на групни социјални активности

НЕГАТИВНИ КАРАКТЕРИСТИКИ

$>$ Има зони кои не се доволно средени и осветлени што го загрозува чувството на безбедност 
$>$ Има проблем со загадувањето со тврд отпад

$>$ Не е соодветен за употреба во зимскиот период и студени денови

$>$ Покрај клупите и малиот број на летниковци нема друг вид на места за седење

$>$ Нема локации со полначи за електронски уреди

$>$ Иако би требало да има бесплатен пристап до wi-fi истиот не функционира добро

\section{Парк на езерата, Аеродром [45]}

Овој релативно нов парк е еден од поголемите во Скопје и државава, со вкупна површина од $12,000 \mathrm{~m}^{2}$, од кои $2,000 \mathrm{~m}^{2}$ се водна површина. Употребата на водни елементи во урбаното планирање е честа низ светот, поради бројните експериментални докази за позитивните ефекти кои ги има погледот кон водна површина и слушањето на водни звуци врз подобрување на менталното здравје, намалувањето на стресот, подобрувањето на способноста за фокусирање, подобрување на сонот и намалување на депресијата $[46,47,48]$. Урбанистичката идеја за овој парк е просторот да биде искористен од жителите за мир, релаксација и грижа за здравјето, особено во жешките летни периоди кога паркот нуди прибежиште од градскиот асфалт и разладување. Нуди повеќе од стотина клупи за одмор, езерца и фонтани, шеталишта, соларни светилки итн. Позитивните аспекти се слични како и оние на Градскиот парк - овозможување конекција со природата, можност за релаксација, за социјална интеракција и за рекреација кои се клучни елементи што влијаат за подобрување на менталното здравје на граѓаните.
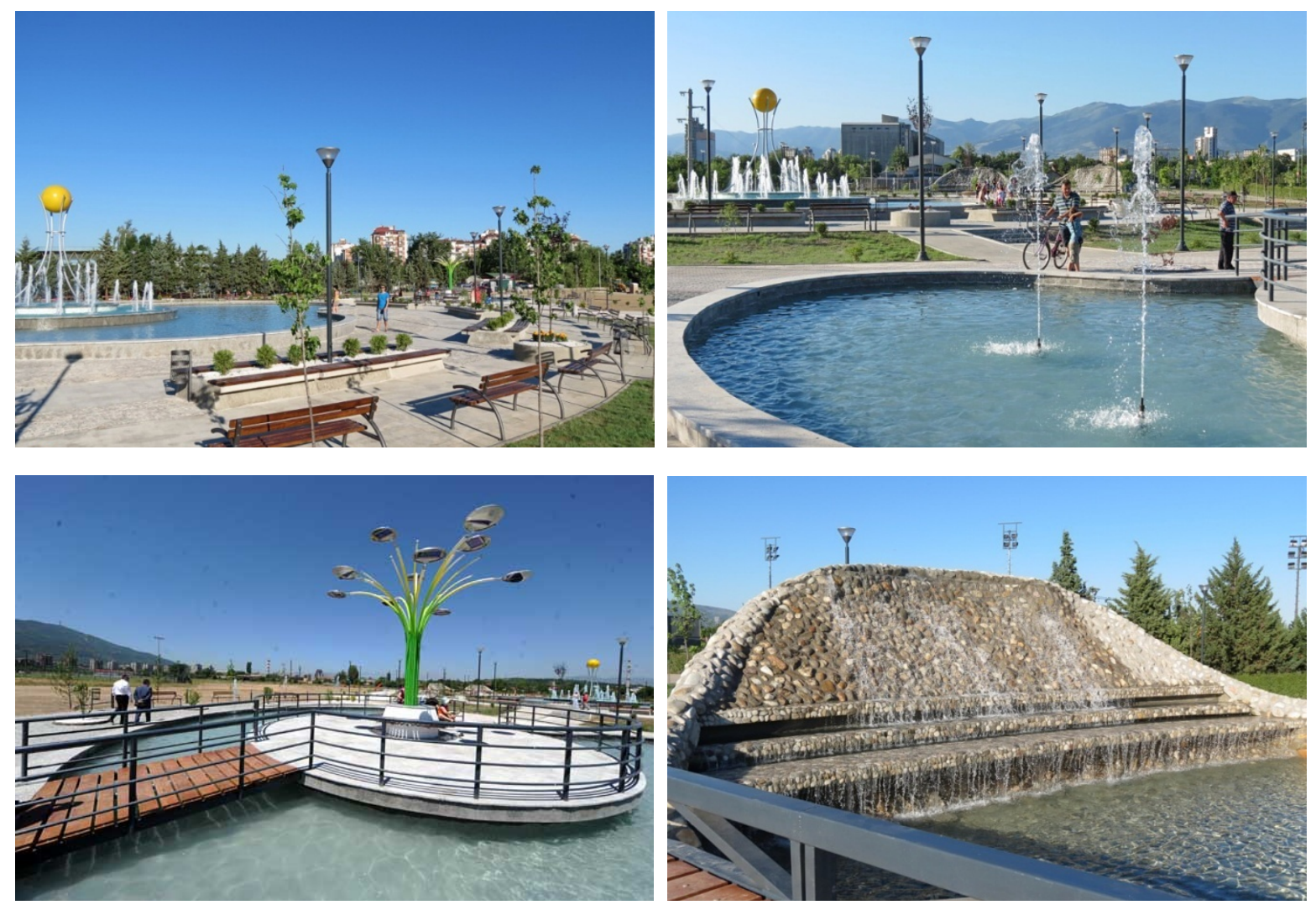

Сл.5.2-7,8,9,10 Парк на езерата, Аеродром. 


\section{ПОЗИТИВНИ КАРАКТЕРИСТИКИ}

$>$ Водните површини и фонтани поттикнуваат позитивно размислување, го редуцираат стресот и анксиозноста, ја зголемуваат концентрацијата

$>$ Шеталиштата се идеални за рекреација

$>$ Бројните клупи овозможуваат одмор и спонтана социјална интеракција

> Има добро осветлување што овозможува слободно користење не само преку ден, туку и во вечерните часови

\section{НЕГАТИВНИ КАРАКТЕРИСТИКИ}

$>$ Не е соодветен за употреба во зимскиот период и студени денови

$>$ Покрај клупите нема друг вид на места за седење

$>$ Нема локации со полначи за електронски уреди

$>$ Нема wi-fi пристап

\section{Зелен парк со езеро, Горно Лисиче [49,50]}

Овој Зелен парк со езеро претставува хортикултурно и партерно уредување на област во населбата Горно Лисиче со вкупна површина од 6,500 $\mathrm{m}^{2}$, од која 2,300 $\mathrm{m}^{2}$ се зелена површина. Идејата е слична како и кај Паркот на езерата во Аеродром, односно нудење на катче за одмор и рекреација на жителите преку комбинирање на зелени и водни површини. Паркот е опремен со висока и ниска вегетација, езеро на две нивоа со пешачки мост, детско игралиште и видиковец.
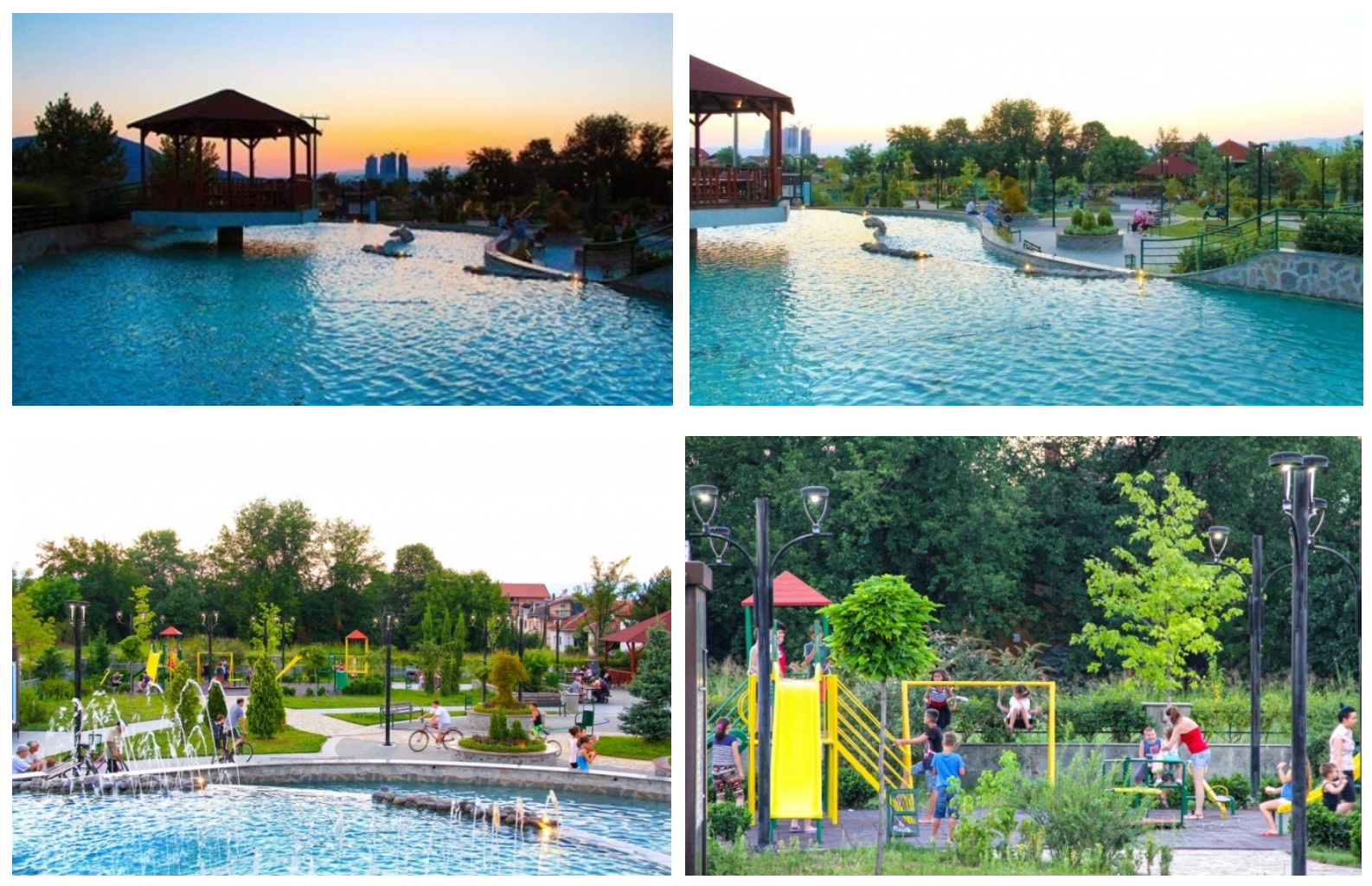

Сл.5.2-11,12,13,14 Зелен парк со езеро, Горно Лисиче. 


\section{ПОЗИТИВНИ КАРАКТЕРИСТИКИ}

$>$ Водните површини и фонтани поттикнуваат позитивно размислување, го редуцираат стресот и анксиозноста, ја зголемуваат концентрацијата

$>$ Каскадната форма на езерцето буди позитивни чувства поради интересниот изглед кој постеќа на мал водопад, како и поради звукот на паѓање на вода

$>$ Видиковецот на езерцето овозможува прекрасен поглед врз целото зеленило на паркот и водната површина што овозможува максимално уживање

$>$ Шеталиштата се идеални за рекреација

$>$ Бројните клупи и летниковците овозможуваат одмор и спонтана социјална интеракција

$>$ Детското игралиште овозможува забава и рекреација за децата додека родителите се дружат или одмараат

\section{НЕГАТИВНИ КАРАКТЕРИСТИКИ}

$>$ Не е соодветен за употреба во зимскиот период и студени денови

$>$ Нема локации со полначи за електронски уреди

$>$ Нема wi-fi пристап

\section{Парк Галија, Козле [51]}

Паркот Галија е лоциран во населбата Козле, спроти студентскиот дом „Гоце Делчев" зафаќа вкупна површина од 10,000 $\mathrm{m}^{2}$, од кои на 6,000 $\mathrm{m}^{2}$ е извршено хортикултурно уредување, а на останатите 4,000 $\mathrm{M}^{2}$ партерно уредување и поплочување со фонтана со должина од 200 м. Ова урбано катче е особено актуелно во попладневните и вечерните часови на пролетните и летни денови кога жителите доаѓаат за прошета и релаксација од секојдневието. Тука доаѓаат жители од различни возрасти за вршење на различни активности - младите родители ги шетаат своите деца или се дружат додека малите ги користат реквизитите од детското игралиште, средношколците и студентите доаѓаат за дружба и прошетка, возрасните вообичаено се социјализираат и одмараат на бројните клупи во паркот, љубителите на животни ги шетаат своите миленци, а спортистите ги користат патеките за рекреација. Паркот е одлично испланирано урбано катче за социјализирање и релаксација.
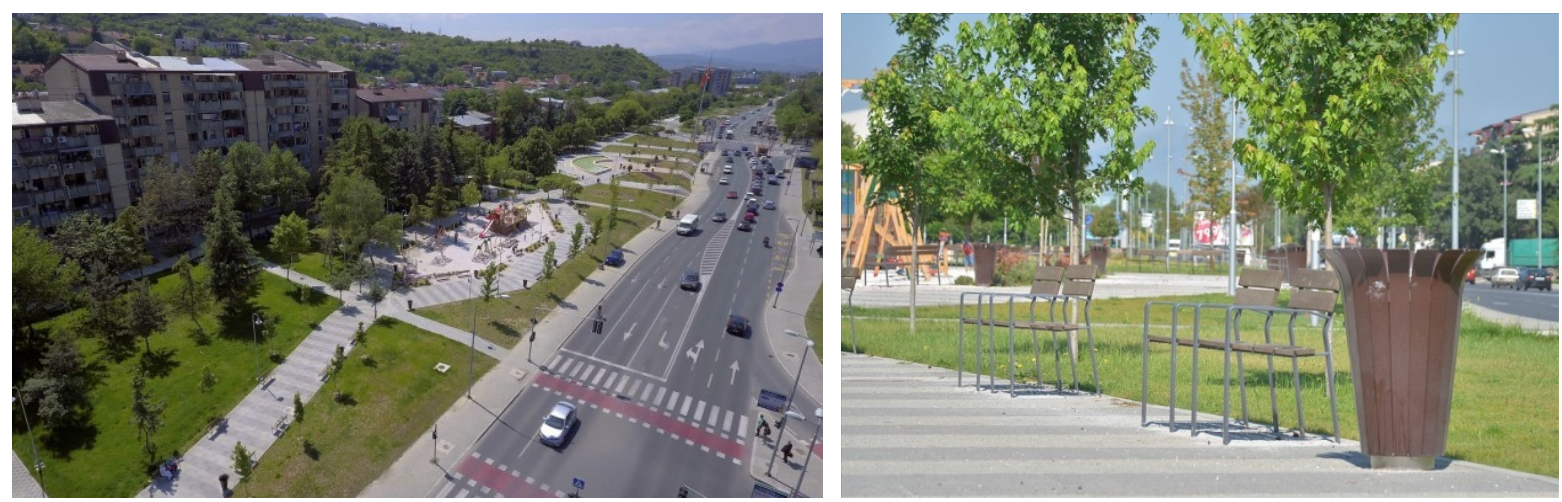

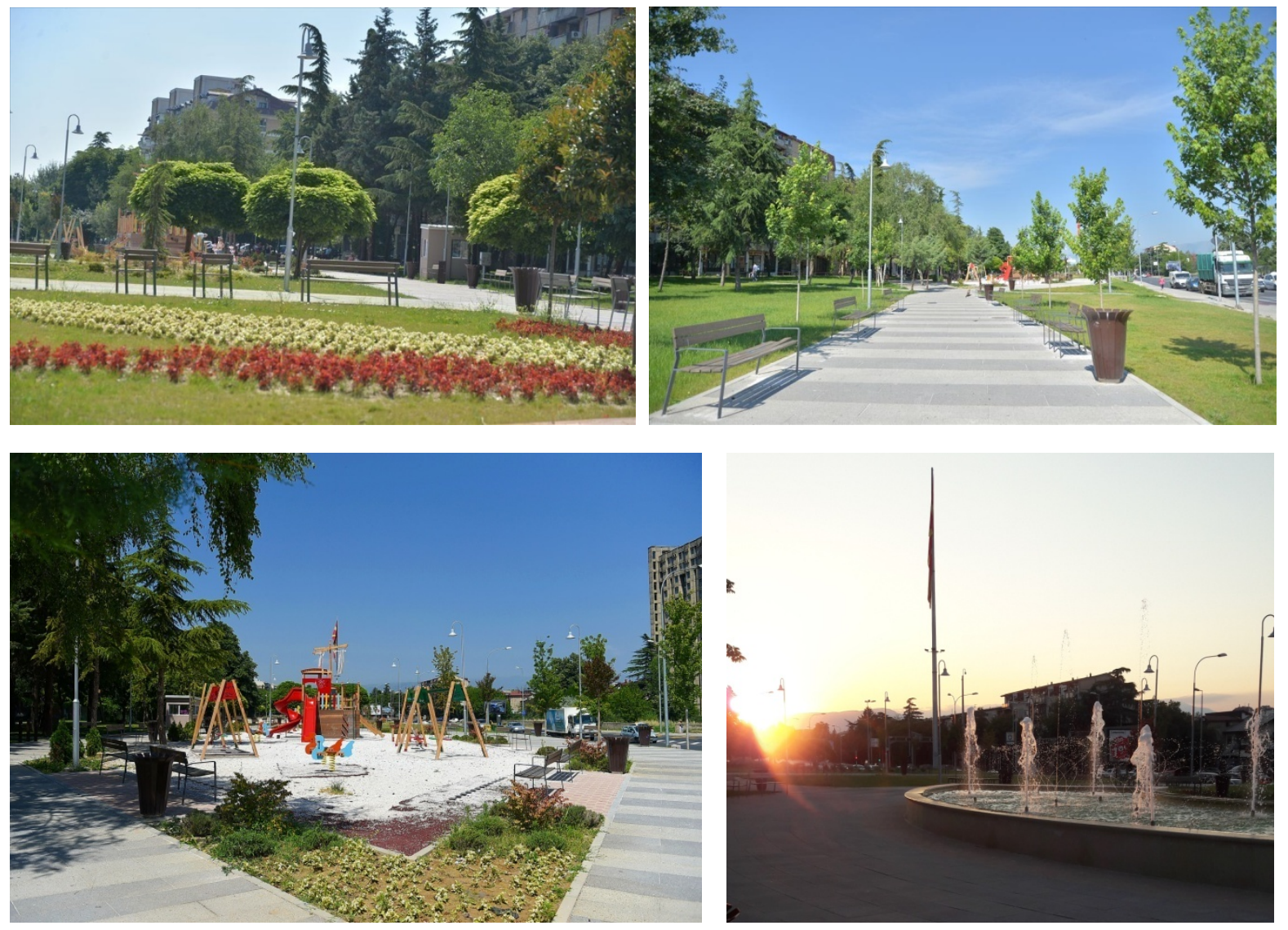

Сл.5.2-15,16,17,18,19,20 Парк Галија, Козле.

\section{ПОЗИТИВНИ КАРАКТЕРИСТИКИ}

$>$ Природните површини и фонтаната ја стимулираат релаксацијата, го поттикнуваат креативното размислување и позитивните чувства

$>$ Броојните клупи се одлични за одмор и спонтана социјална интеракција

> Поединечните клупи наменети само за едно лице се идеални за индивидуален одмор и интроспекција

$>$ Детското игралиште овозможува забава и рекреација за децата додека родителите се дружат или одмараат

$>$ Паркот е „pet-friendly“ што значи дека е одлично место за прошетка и дружба и на оние кои чуваат миленичиња

\section{НЕГАТИВНИ КАРАКТЕРИСТИКИ}

$>$ Не е соодветен за употреба во зимскиот период и студени денови

$>$ Неговата локација е веднаш до прометниот булевар што ја намалува безбедноста и ја зголемува звучната загаденост што го нарушува чувството на „бегање“ од градскиот метеж

$>$ Нема локации со полначи за електронски уреди

$>$ Нема wi-fi пристап 


\section{Јавен плоштад, Карпош 3 [52]}

Овој мал плоштад во Карпош 3 претставува одличен пример за урбано катче посветено на подобрување на секојдневието на жителите. Целосниот дизајн на просторот е забавен и буди позитивни чувства и реакции преку разиграниот дизајн на "Уличниот мебел“ и на паркиралиштата за велосипеди, современата тенда на детското игралиште, фонтаната кај која водата отскокнува од земјата, шарените цвеќиња насадени покрај пешачките патеки, големите дрвја под кои се сместени клупите со масички итн. Просторот е совршен за забава и дружба на жители од најразлични возрасти.
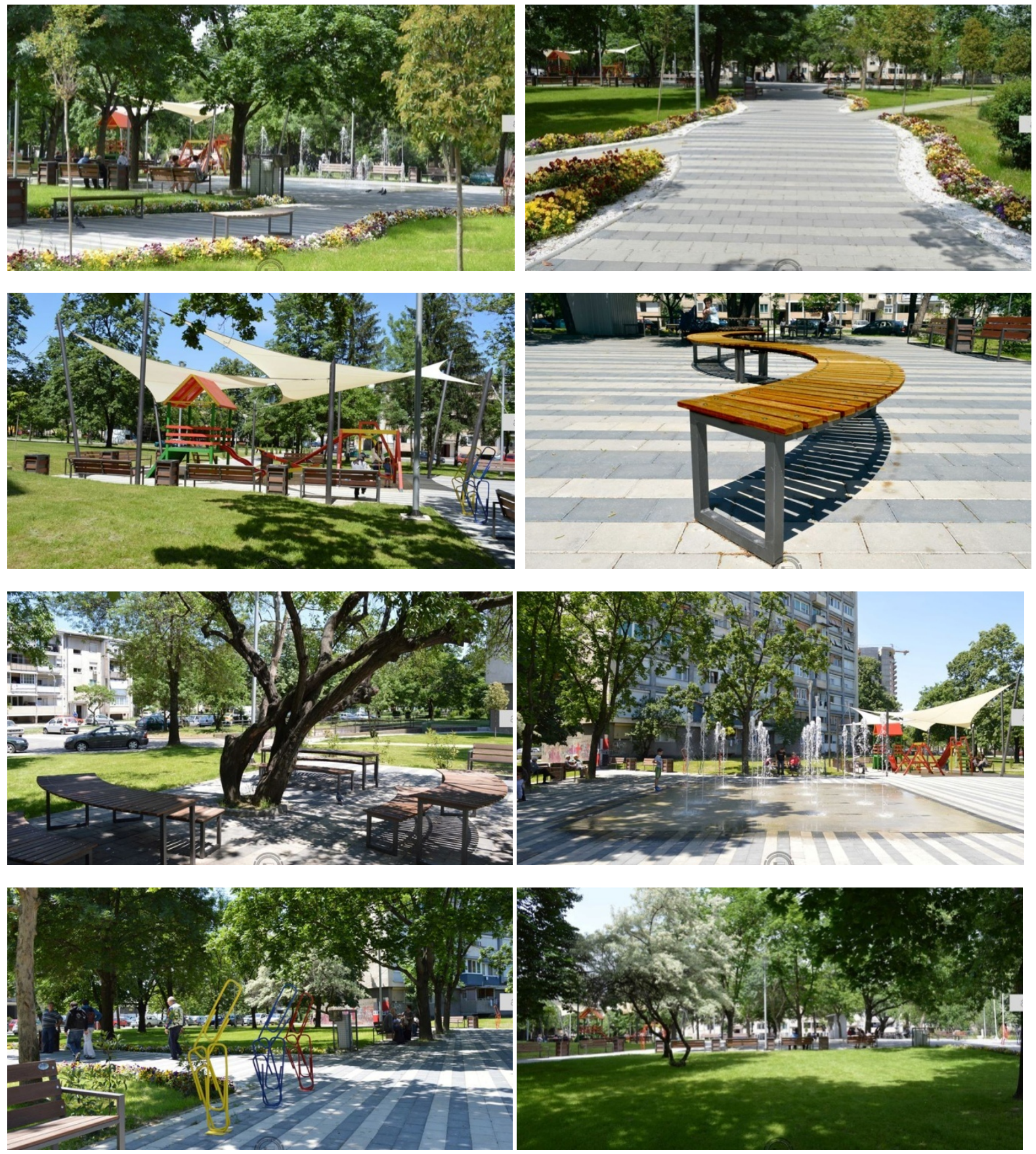

Сл.5.2-21, 22,23,24,25,26,27,28 Јавен плоштад, Карпош 3. 
$>$ Целосниот „игрив“ урбан дизајн на просторот поттикнува позитивни емоции

$>$ Природните површини и фонтаната ја стимулираат релаксацијата, го поттикнуваат креативното размислување

$>$ Фонтаната овозможува забава и освежување во топлите денови

$>$ Броојните големи клупи се одлични за одмор и спонтана социјална интеракција

$>$ Клупите со масички се идеални за пикник во природа, играње карти, табла, или останати друштвени игри

$>$ Детското игралиште овозможува забава и рекреација за децата додека родителите се дружат или одмараат

$>$ Има паркиралиште за велосипеди кое има и функционална и естетска намена

\section{НЕГАТИВНИ КАРАКТЕРИСТИКИ}

Не е соодветен за употреба во зимскиот период и студени денови

$>$ Нема локации со полначи за електронски уреди

$>$ Нема wi-fi пристап

\section{3 ЗАКЛУЧОК ОД АНАЛИЗА НА ПОСТОЕЧКИ ПРИМЕРИ}

Според направената анализа на пазарот, јасно е видливо дека во светот се обрнува поголемо внимание на дизајнирање на урбана опрема која е во функција на подобрување на расположението на граѓаните и олеснување на нивното секојдневие. Во Скопје, иако постојат прекрасни паркови наменети за јавна употреба и рекреација, нивното користење и функционирање е ограничено поради тоа што не можат да се употребуваат во текот на целата година, не нудат можности за работа во нив, немаат доволна безбедност, имаат проблем со загадувањето итн. Во град Скопје не постојат урбани павиљони каде луѓето може да поминуваат време во текот на денот. 


\section{6. ПОСТАВУВАЊЕ ХИПОТЕЗИ}

Врз база на направените теоретски и етнографски истражувања, како и анализа на пазарот, согласно со согледаната потреба и идеја за производ може да се дефинираат следните хипотези:

1. Доколку во град Скопје постојат соодветно опремени урбани павиљони истите би го решиле проблемот со недостаток на простор за поминување време на пауза, прекувремена работа, состаноци, социјализирање и сл. и на граѓаните би им претставувало задоволство да ги употребуваат.

2. Доколку во град Скопје постојат соодветно опремени урбани павиљони истите би влијаеле врз значително редуцирање на стресот на граѓаните во нивното секојдневие и долгорочно подобрување на нивното ментално здравје.

Од понатамошните практични истражувања и нивни евалуации во овој магистерски труд овие дефинирани хипотези ќе бидат потврдени или побиени. 


\section{7. ДЕФИНИРАЊЕ НА ДИЗАЈНЕРСКИ ЦЕЛИ}

По направената анализа на пазарот и дефинирање на хипотези, следен чекор беше да се дефинираат дизајнерските цели кои служат како насоки што треба да се следат при генерирањето на концепти. За генерирање на дизајнерски цели, односно инженерски спецификации е употребен QFD методот, познат како „куќа на квалитет“ (Таб.7-1).

При конструирањето на куќата на квалитет, најпрво беа дефинирани 3 групи на корисници кои се засегнати од карактеристиките на павиљонот, а тоа се: граѓаните кои би требало секојдневно да го употребуваат, лица од општината (градот) кои треба да одобрат негово градење и лица од фирмите во градот кои би требало да посакаат да инвестираат во ваков простор поради мислење дека тој ќе претставува додадена вредност за таа компанија.

Понатаму, беа дефинирани барањата на корисниците, карактеристики кои тие би сакале да ги поседува павиљонот. Секоја од тие карактеристики беше рангирана според важноста посебно за секоја корисничка група. На пример, за граѓаните меѓу најважните карактеристики се заштитата од временски услови, безбедната употреба и удобноста, мултифункционалноста, привлечниот дизајн итн. Додека за лицата од општина и фирмите меѓу поважните карактеристики се издржливоста на објектот, вклопувањето во околината, бројот на луѓе кои ќе може да го користат, мултифункционалноста, еколошкиот аспект итн.

Следниот чекор, беше описна оценка на скала од 1 до 5 во однос на тоа колку добро конкурентите ги задоволуваат дефинираните барања. Како конкуренти беа издвоени Градски парк Скопје, Парк Галија и Парк на езерата. По оценувањето се покажа дека конкурентите добро ја вршат функцијата во некои аспекти - пространи се, собираат голем број на луѓе, се наоѓаат во природа и слично, но поради тоа што тие се паркови немаат голем број од функциите кои би ги имал еден урбан павиљон.

Понатамошната фаза во процесот на развој на күќата на квалитет беше формулирање на множество инженерски спецификации кои се мерливи параметри изведени од барањата на корисниците и помагаат при добивање на точни дизајнерски цели. Најпрво инженерските спецификации беа разгледани во однос на барањата, во однос на тоа колку силно една спецификација е поврзана со задоволување на едно барање (9-силно, 3-средно, 1-слабо), потоа на ист начин беше разгледан нивниот меѓусебен однос и поврзаност едни со други.

На крај, за секој од конкурентите беше впишана вредноста за сите дефинирани спецификации. Според овие вредности е видливо во која мера тие ги задоволуваат барањата на корисниците. Конечно, во последниот ред од куќата на квалитет, се 
извлечени заклучоци од целосната анализа во вид на дизајнерски цели кои новиот дизајн мора да ги задоволи за да има предност пред конкуренцијата.

\begin{tabular}{|c|c|c|c|c|c|c|c|c|c|c|c|c|c|c|c|c|}
\hline QFD & $\begin{array}{l}\frac{x}{7} \\
\text { 意 } \\
\text { 愛 }\end{array}$ & 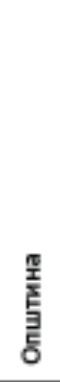 & $\frac{\frac{a}{2}}{\frac{a}{\frac{a}{\theta}}}$ & 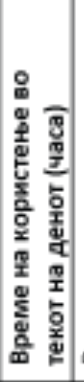 & 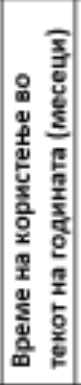 & 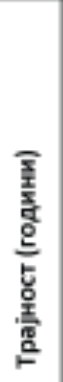 & 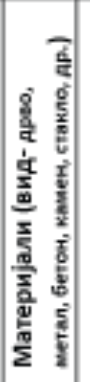 & 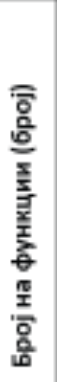 & 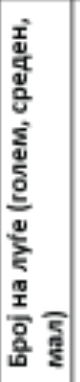 & 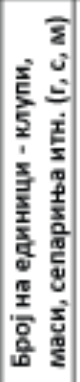 & 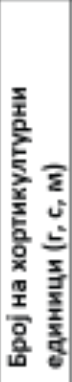 & 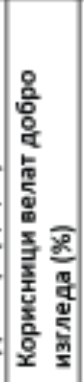 & 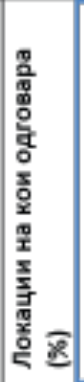 & 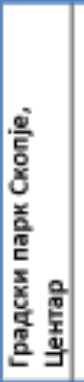 & 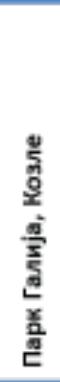 & 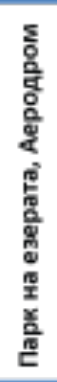 \\
\hline \multicolumn{17}{|l|}{ Функционални карактеристики } \\
\hline $\begin{array}{l}\text { Заштита од лоши временски } \\
\text { услови }\end{array}$ & 1 & 14 & 9 & 9 & 9 & 3 & 9 & 9 & & & & 3 & & 1 & 1 & 1 \\
\hline Заштита од сонце (UV) и отсјај & 2 & 15 & 10 & 9 & 9 & 3 & 9 & 9 & & & & 3 & & 1 & 1 & 1 \\
\hline Осветленост (дневна и ноќна) & 3 & 16 & 11 & 9 & 9 & & 3 & 9 & 9 & 1 & & 3 & 3 & 2 & 3 & 4 \\
\hline Вентилација & 15 & 17 & 12 & 9 & 9 & & & 9 & 9 & & & & & 5 & 5 & 5 \\
\hline Wi-fi пристаn & 6 & 19 & 4 & 9 & 9 & & & 9 & 9 & & & 1 & & 1 & 1 & 1 \\
\hline Полнење на електрични уреди & 7 & 20 & 5 & 9 & 9 & & & 9 & 9 & 9 & & 1 & & 1 & 1 & 1 \\
\hline Квалитетна изработка & 16 & 7 & 3 & 9 & 9 & 9 & 9 & 3 & & 3 & 3 & 9 & & 2 & 3 & 4 \\
\hline Мултифункционалност & 4 & 6 & 1 & 9 & 9 & 3 & & 9 & 3 & 9 & 3 & 3 & 3 & 2 & 2 & 2 \\
\hline Изаржливост & 21 & 1 & 2 & 9 & 9 & 9 & 9 & 9 & 9 & 3 & & 9 & 3 & 3 & 3 & 3 \\
\hline \multicolumn{17}{|l|}{ Човечки фактори } \\
\hline Доволно простор & 9 & 8 & 13 & 9 & 9 & & & & 9 & 3 & & 3 & & 5 & 5 & 5 \\
\hline Можност за приватност & 8 & 21 & 6 & 9 & 9 & & & 1 & 9 & 9 & & 1 & & 5 & 3 & 2 \\
\hline Удобност (ергономија) & 5 & 18 & 7 & 9 & 9 & & 9 & 9 & 9 & 9 & & 9 & & 3 & 3 & 3 \\
\hline Безбедност & 10 & 9 & 8 & 9 & 9 & & 9 & 9 & 9 & 3 & 1 & 3 & & 2 & 2 & 3 \\
\hline Лесен пристап & 11 & 10 & 15 & 9 & 9 & & & & & & & 1 & 3 & 5 & 5 & 5 \\
\hline Лесна употреба & 12 & 11 & 14 & 9 & 9 & & 1 & 9 & & 1 & & 1 & & 5 & 5 & 5 \\
\hline Надежност & 20 & 12 & 21 & 3 & 3 & 9 & 9 & 9 & 3 & 9 & & 3 & & 4 & 3 & 3 \\
\hline Привлечен дизајн & 17 & 13 & 20 & 1 & 1 & & 9 & 3 & 1 & 9 & 9 & 9 & 9 & 2 & 3 & 4 \\
\hline \multicolumn{17}{|l|}{ Контакт со природа } \\
\hline Врска со околината & 13 & 3 & 18 & & & 9 & 9 & 3 & & & 9 & 9 & 9 & 5 & 3 & 5 \\
\hline Еко материјали & 19 & 5 & 17 & & & 9 & 9 & & & 3 & 3 & 3 & 9 & 4 & 4 & 4 \\
\hline Не ја загадува средината & 14 & 4 & 16 & & & 9 & 9 & 9 & & & 9 & 3 & 9 & 5 & 5 & 4 \\
\hline Се вклопува во околината & 18 & 2 & 19 & & & 3 & 9 & 3 & & & 3 & 9 & 9 & 5 & 3 & 5 \\
\hline Градски парк Схопје, Центар & & & & 24 & 7 & 5 & AM Б & 2 & $\mathbf{r}$ & $\mathbf{r}$ & $\mathbf{r}$ & $60 \%$ & & & & \\
\hline Парк Галија, Козле & & & & 24 & 7 & 5 & AM E & 2 & $r$ & c & c & $40 \%$ & & & & \\
\hline Парк на езерата, Аеродром & & & & 24 & 7 & 5 & A $M$ L K & 2 & $\mathbf{r}$ & C & c & $50 \%$ & $>$ & & & \\
\hline Цели & & & & 24 & 12 & 10 & A & 10 & $\mathrm{MCr}$ & $r$ & $\Gamma$ & $>80 \%$ & $>50 \%$ & & & \\
\hline
\end{tabular}

Taб.7-1 QFD дијаграм за дефинирање на дизајнерски цели. 


\section{1 КОНЕЧНИ ЦЕЛИ ЗА ДИЗАЈН НА ПАВИЉОН}

На веновиот дијаграм подолу (Граф.7.1-1) сликовито се прикажани главните цели кои ги задоволуваат барањата на корисниците. Во жолтиот сегмент се набројани дел од целите кои ќе ги задоволат барањата важни за граѓаните, во синиот се издвоени целите соодветни на барањата на општините и фирмите, а пресекот ги покажува целите што ќе помогнат дизајнот да ги задоволи сите барања кои се заеднички за граѓаните и општините.

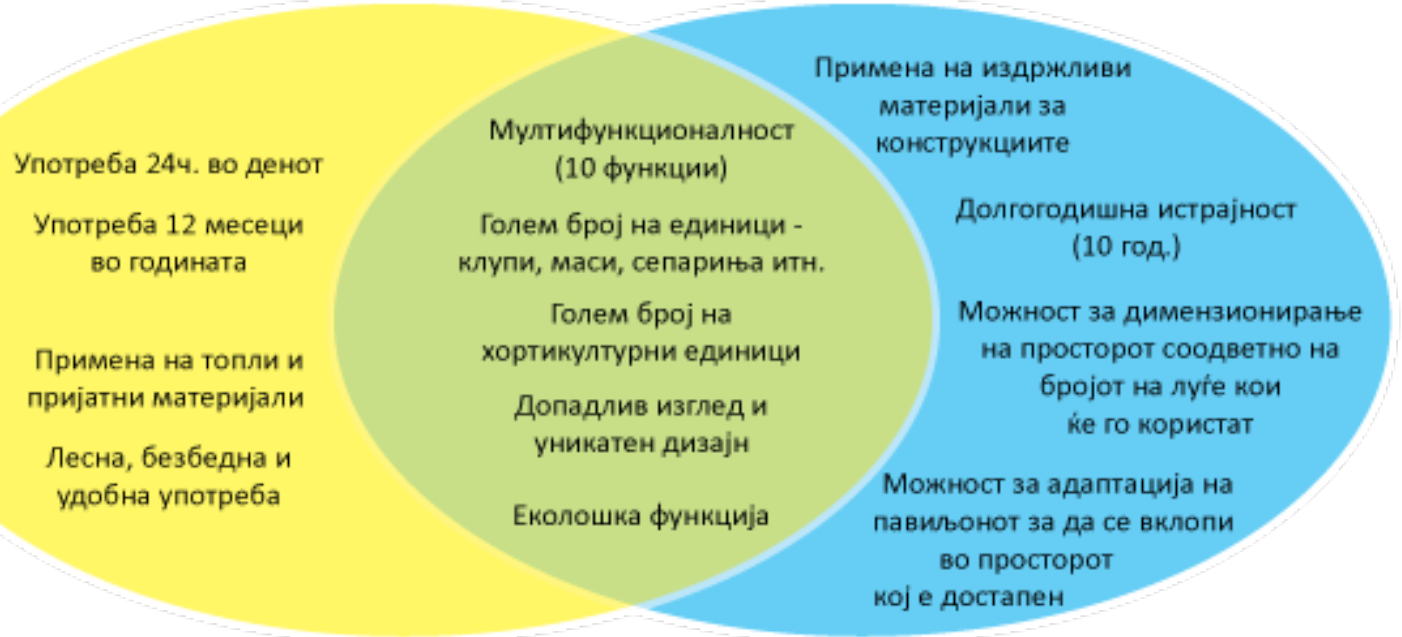

Граф. 7.1-1 Венов дијаграм за графички приказ на барањата на корисниците.

Конечно, како резултат на направената куќа на квалитет изведени се следните дизајнерски цели:

- Павиљонот треба да може да се употребува нон-стоп 24 часа.

Ова е важно за граѓаните бидејќи им е потребен простор каде ќе може да отидат без разлика која смена се на работа, без разлика дали работат прекувремено или го користат просторот во текот или по завршување на работното време.

- Павиљонот треба да има можност да се употребува 12 месеци во годината, без прекин во можноста за употреба и при непогодни временски услови.

Корисниците на павиљонот не треба да се ограничени од надворешните временски услови и нивната употреба на овој павиљон не смее да биде спречена од надворешни непогоди - студени денови, дожд, ветер, силно сонце и сл. Во Скопје нема вакви простори кои се наоѓаат на отворено и граѓаните може да ги употребуваат 12 месеци во годината.

- Павиљонот треба да биде издржлив и истраен, да може да се користи без поголеми обнови и рекоснструирања минимум 10 години. 
Ова е од голема важност за финансиерите. Квалитетна конструкција и соодветно одржување ќе ги намалат трошоците за често репарирање.

- Употреба на издржливи, но пред се „топли“ материјали - дрво.

Употребата на цврсти конструкции отпорни на надворешните влијанија е од големо значење за јавен објект наменет за употреба од повеќе лица, но пријатниот изглед на целата конструкција е уште поважен за павиљон чија намена е да го зголеми позитивното расположение. Поради тоа изборот на главниот материјал за конструкцијата и елементите е дрво. Дрвото е обновлив материјал кој се класифицира како „топол“, односно контактот со него е пријатен и при повисоки и при пониски температури.

- Мултифункционалност - задоволување на 10 функции.

Павиљонот за да го оправда своето постоење и намена мора да биде мултифункционален и да нуди многу повеќе можност од обичните паркови. Тој треба да ги има следните карактеристики (функции) :

$\checkmark$ Употреба како отворен простор

$\checkmark$ Употреба како затворен простор

$\checkmark$ Заштита од временски услови

$\checkmark$ Адаптација на просторот според бројот на корисници

$\checkmark$ Полнење на електрични уреди

$\checkmark$ Пристап до wi-fi

$\checkmark$ Можност за приватна работа и одмор

$\checkmark$ Можност за групна работа и дискусии

$\checkmark$ Можност за социјализирање

$\checkmark$ Можност за релаксација

$\checkmark$ Еколошка фукнкција

- Павиљонот треба да биде наменет за мали, средни или големи групи на луѓe.

Под ова се подразбира дека неговиот волумен и простор треба да овозможуваат нормално функционирање на групата луѓе за која е наменет. Премногу луѓе би ја нарушиле можноста за приватност, а премалку би го нарушиле концептот за остварување позитивни социјални интеракции. Поради тоа би требало да има можност за промена на димензиите според намената и потребата (барања на компании и општини).

- Павиљонот мора да има голем број на единици - маси, клупи, сепариња, лежаи, полначи за електрични уреди и сл.

Доволниот број на единици значи задоволство кај корисниците.

- Павиљонот мора да има голем број на хортикултурни единици. 
Ова е дефинирано како цел поради потребата да се овозможи чувството на престојување во природа и поглед кон природни елементи при работа и релаксација.

- Павиљонот мора да има допадлив изглед за најголемиот број од корисниците реална цел е барем $80 \%$ од нив да сметаaт дека дизајнот е убав.

Ова би се постигнало преку црпење на инспирација од природата за да се добие уникатен дизајн кој изобилува со карактеристични форми и текстури. Дизајнот треба да биде лесен, „транспарентен“ и во единство со природата која е во опкружувањето. Преку него, на посетителите треба да им се врати чувството на поврзаност со природата, тие треба да имаат доволно светлина, допир со природни површини и поглед кон природни елементи со што ќе им се зголеми чувството на релаксација, спокој и позитивни мисли без разлика дали го користат просторот за работа, одмор или социјализирање.

- Дизајнот на павиљонот би требало да овозможи можност за негово поставување на над $50 \%$ од слободните локации во општините и покрај објектите на компаниите.

Павиљонот треба да има можност за одредена флексибилност на димензиите и варијациите со цел да може да се вклопи на повеќе локации. Напоменатиот процент (50\%) се однесува на оној дел од вкупниот слободен простор во град Скопје на кој би можело да се изгради ваков павиљон. Овој процент е реална цел, со оглед на тоа што густината на населението и градбите кои веќе постојат не секаде оставаат можност за доградба на дополнителни објекти од овој тип. 


\section{8. РАЗВОЈ НА ИДЕЈА}

Првичната фаза во развојот на производот претставува разработка на идејата за него која ќе резултира со генерирање на неколку концептни решенија околу изгледот и функцијата со цел конечниот дизајн успешно да ги задоволува споменатите дизајнерски барања, а преку тоа, да ги задоволи дефинираните потреби на корисниците.

\section{1 МОДУЛАРНИ СИСТЕМИ}

Модуларноста претставува карактеристика на еден систем чии компоненти можат да бидат одделени или интегрирани без промена на нивните својства или својствата на остатокот од системот, а со тоа ја подобруваат ефикасноста на целокупната мрежна активност на еден систем. Модуларноста постои во природата и може да биде проучувана на речиси секоја скала од биолошката организација, од молекуларните интеракции, па се до функцијата на целокупниот организам.

Модуларноста на природните системи е поврзана со еволуцијата и потекнува уште од најраните формации на едноклеточни организми, пред 3 билиони години, кои постепено се развивале, поврзувале и растеле во поголеми системи, за пред 500 милиони години да се појават првите повеќеклеточни организми.

Карактеристичен пример за постоењето на модуларност во природата е начинот на развој на растенијата кои растат во целиот тек на нивниот живот преку повторливо надоврзување на нивните основни составни делови - модули. Секој модул се состои од стебленце, неколку лисја и пупка (Сл.8.1-1). Доколку растението изгуби дел од својата структура, оштетениот дел лесно може да биде заменет со надоврзување на нови модули.

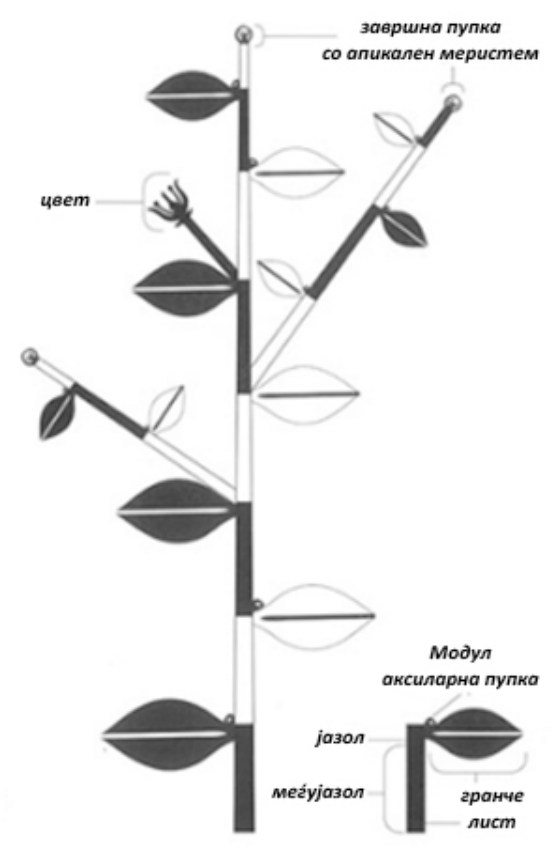

Сл.8.1-1 Модуларност кај растенијата. 
Принципите на модуларност имаат бројни бенефиции меѓу кои:

- Можност за скалирање и растење. Растењето на системот и во големина и во број на функции е едноставно овозможен преку надградба на модуларните елементи.

- Едноставен процес на дуплирање. Дуплирањето на помали, поедноставни сегменти е полесно, побрзо и посигурно од дуплирањето на комплексни структури.

- Можност за специјализирање на функциите на модулите. Специјализацијата на клеточните задачи ја овозможува истата ефективност и ефикасност кои се својствени за тимската работа. Во раните мултиклеточни организми, еден вид на клетка била специјализирана за моторика, друг вид за заштита, трет за лоцирање на храна итн.

- Брзо адаптирање на средината. Преку додавање, одземање или измена на модулите, секакво менување на дизајнот може да биде тестирано и побрзо отфрлено или усвоено.

- Толеранција на грешки. Доколку еден од модулите има проблем, истиот нема да го наруши функционирањето на остатокот од системот. Тој може едноставно да биде поправен или заменет со нов [58].

Сите споменати принципи се причина за практикување на модуларните системи во индустрискиот дизајн. Модуларните системи овозможуваат флексибилност на дизајнот како и намалување на трошоците поради вложување на ресурси само во креирање на еден модул, а потоа негово реплицирање според потребите.

Креирање на модуларен павиљон би значело негова едноставно пренаменување за употреба во различни средини и за различен број на луѓе, согласно со потребите на општината или фирмата за која ќе се конструира. Преку ова би се задоволиле голем број од барањата на корисниците меѓу кои спаѓаат и: добра врска со околината, издржливост и долготрајност на системот, мултифункционалност, лесна употреба, и простор креиран според бројот на негови корисници со што се оневозможува ризикот тој да биде премал за нив и да побуди негативни чувства и незадоволство, или да биде преголем со што ќе се загрози чувството на удобност, приватност и безбедност.

\section{2 АДАПТАЦИЈА НА ОКОЛИНАТА}

Со цел одговарање на барањето на корисниците просторот да може да се употребува секојдневно, во било кој период од годината, павиљонот мора да биде дизајниран на начин што ќе се адапира на околината во која се наоѓа и ќе ги користи бенефициите кои таа ги нуди, истовремено штитејќи од сите непогоди.

Ова подразбира предвидување на простор кој може да се употребува и во студени и во топли денови, односно простор кој ќе може да функционира како отворен и затворен со овозможување добро осветлување и вентилација притоа штитејќи од студено време, ветер и дожд, но и од силни светлосни зраци, отсјај и жештина. 
Поради тоа, идејата за овој павиљон е истиот да биде конструиран како волумен кој ќе има транспарентна обвивка поради потребата од доволна количина на природна светлина, но истиот ќе може да се употребува или како целосно затворен или делумно отворен простор преку поставување на механизми за отворање. Како метод на заштита на оваа обвивка, на одредени нејзини сегменти е предвидено надоврзување на динамични системи кои ќе функционираат како соодветна бариера со околината и ќе овозможат максимален комфор на корисниците на павиљонот во текот на целиот ден со тоа што ќе остваруваат оптимален продор на светлина и заштита од пресилни сончеви зраци и отсјај, особено во жешките летни денови.

Инспирацијата за овој начин на адаптација на околината потекнува од природните системи кои користат ефективни начини на прилагодување на променливата околина со цел да овозможат преживување и напредок. Растенијата ги движат своите листови под различни агли во текот на денот - поим наречен хелиотропизам. Ова им овозможува на листовите да завземат хоризонтална положба во текот на утрата и раното пладне кога сончевите зраци не се толку интензивни и на растенијата им е потребна ефективност при собирањето на доволно светлина и топлина за вршење на природните процеси. Но, листовите може да се собираат во вертикална положба во часовите по пладне кога има пресилна сочева радијација и листовите би можеле да се оштетат од прегревање.

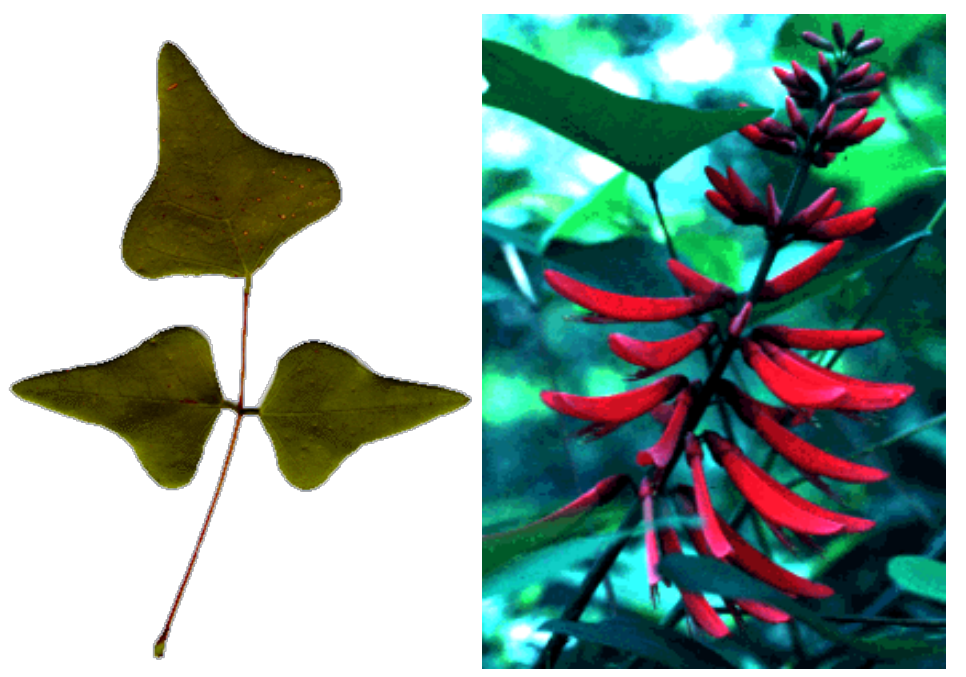

Сл.8.2-1,2 Листовите на растението „Erythrina herbacea ".

Листовите на растението „Erythrina herbacea “ [59], прикажано на сликите погоре (Сл.8.2-1,2), се групирани по 3 на главното стебло, под секој лист има задебелување кое функционира како зглоб и преку него листовите го менуваат аголот во текот на денот. Измените во формата на овој дел за истиот да функционира како зглоб на ротирање се случуваат поради осмотични промени во клетките предизвикани од размена на јони. Листовите покажуваат хелиотропно движење (хелио = сонце, тропно = ориентација како одговор на векторски стимул). Вообичаено, нивната ориентација се карактеризира како дија-хелиотропна, кога површините на листовите се паралелни на сончевите зраци, или пара-хелиотропна кога површините на листовите се во линија со сончевите зраци. Дија-хелиотропна положба се случува во раните утра и попладневните часови кога интензитетот на зрачење не е толку голем, додека пара-хелиотропна положба има во пладневните часови кога сончевите зраци 
имаат силен интензитет. Во ноќта, растенијата ги исклучуваат „јонските пумпи“ и листовите завземаат вертикална положба на спиење.

На сликата подолу (Сл.8.2-3,4) се прикажани трите положби на листовите положба на спиење (сина боја), положба во пладневните часови (жолта боја) и полжба во остатокот од денот кога сонцето е најповолно (зелена боја).
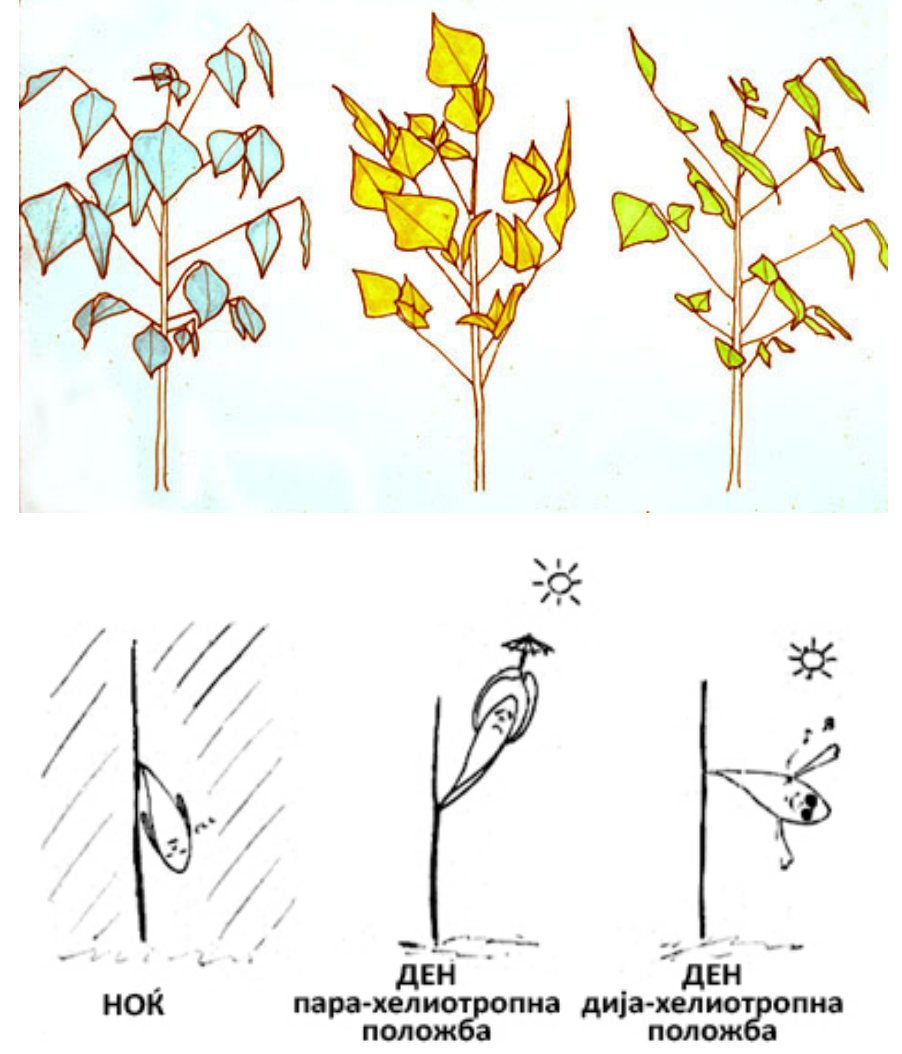

Сл.8.2-3,4 Три положби на листовите на растението „Erythrina herbacea “во текот на денот.

Примената на принципите на заштита од сончеви зраци кои ги користат растенијата при дизајнирањето на павиљонот би помогнале истиот да добие динамичен фасаден систем кој ќе овозможи идеална употреба на дневната светлина и заштита од сончеви зраци, но истовремено и намалување на потрошувачката на енергија - за осветлување и за ладење на просторот. Концептот на креирање динамични фасади е веќе започнат и во развој, евидентно во примери на повеќе светски локации.

\section{3 ДИНАМИЧНИ ФАСАДИ}

Во текот на последниве години, како што станува се поактуелна темата за заштита на животната средина, започна да се наметнува тематиката на дизајнирање еколошки ефикасни производи. На полето на архитектурата, се појави размислувањето дека фасадите на објектите покрај тоа што исполнуваат естетска улога би можеле да бидат и функционални, односно да се адаптираат на средината во која се наоѓаат (на промената на климатските услови), а на тој начин да овозможат значајна енергетска заштеда. Во овој контекст, архитектите започнаа со дизајнирање на динамични фасади 
чија цел е да помогнат во развојот на одржлива и одговорна архитектура. Динамичните фасади делуваат како филтри помеѓу внатрешноста и надворешноста, овозможувајќи им на корисниците да обезбедат соодветно засенување, продор на сончева светлина, вентилација и визуелно поврзување со динамичната надворешна околина [53].

Дневното осветлување во зградите обезбедува мултидимензионални бенефиции. Овозможувањето на продор на дневна светлина преку отворите во објектите го ослободува погледот кон надворешноста што придонесува за визуелна и психолошка удобност, психичко здравје и продуктивност. Дополнително, дизајнерските стратегии за оптимално искористување на дневната светлина ја намалуваат потребата од користење на вештачко осветлување и ја намалуваат потрошувачката на енергија. Но, иако дневното осветлување има многу предности, истото има и несакани ефекти како зголемена топлина и отсјај. Поради тоа, успешните дизајни ја разгледуваат можноста за намалување на одблесокот и вишокот на топлина во објектите. Се употребуваат соодветни пасивни или активни системи на засенување за да се обезбеди соодветен баланс меѓу топлината, светлината, вентилацијата и приватноста во објектот. Активните системи на засенување наспрема пасивните имаат доста предности бидејќи овозможуваат максимално адаптирање на надворешните услови, а со тоа и максимален комфор на коринсниците на просторот.

Во прилог следат неколку издвоени примери со интересен дизајн на динамични фасади.

\subsection{1 Примери на примена на динамични фасади}

\section{„Arab World Institute / Enrique Jan + Jean Nouvel + Architecture-Studio“, Париз, Франција, 1988 [54]}

Овој објект е еден од првите архитектонски дела со вклучени сензори кои даваат автоматски одговор на средината во која се наоѓаат. Фасадата е поделена на мрежи кои се состојат од фотосензитивни механички уреди што се однесуваат слично како автоматизирани леќи и ја контролираат светлината која влегува во објектот. Има 30,000 фотосензитивни дијафрагми на 1,600 елементи кои функционираат како леќи на камера. Сите механички уреди се поврзани со централен компјутер. Базирано на квалитетот на светлина во просториите, леќите се отвораат или затвораат постепено.
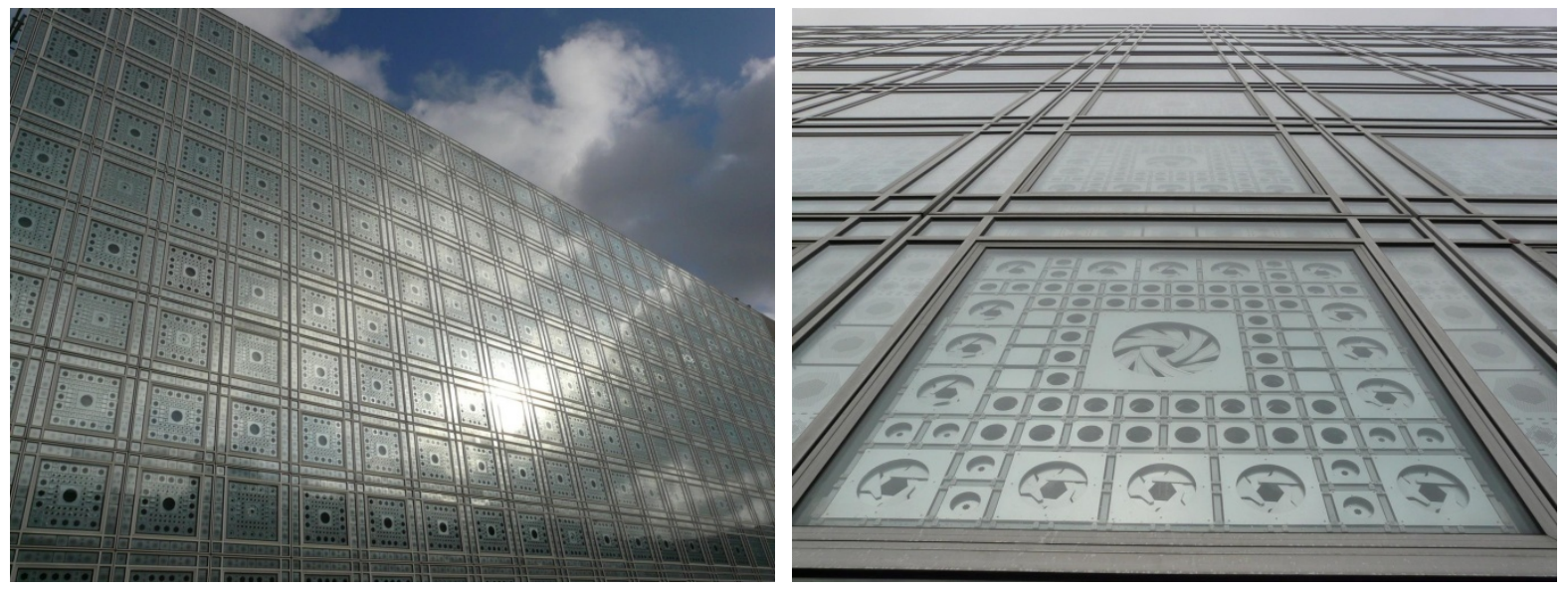

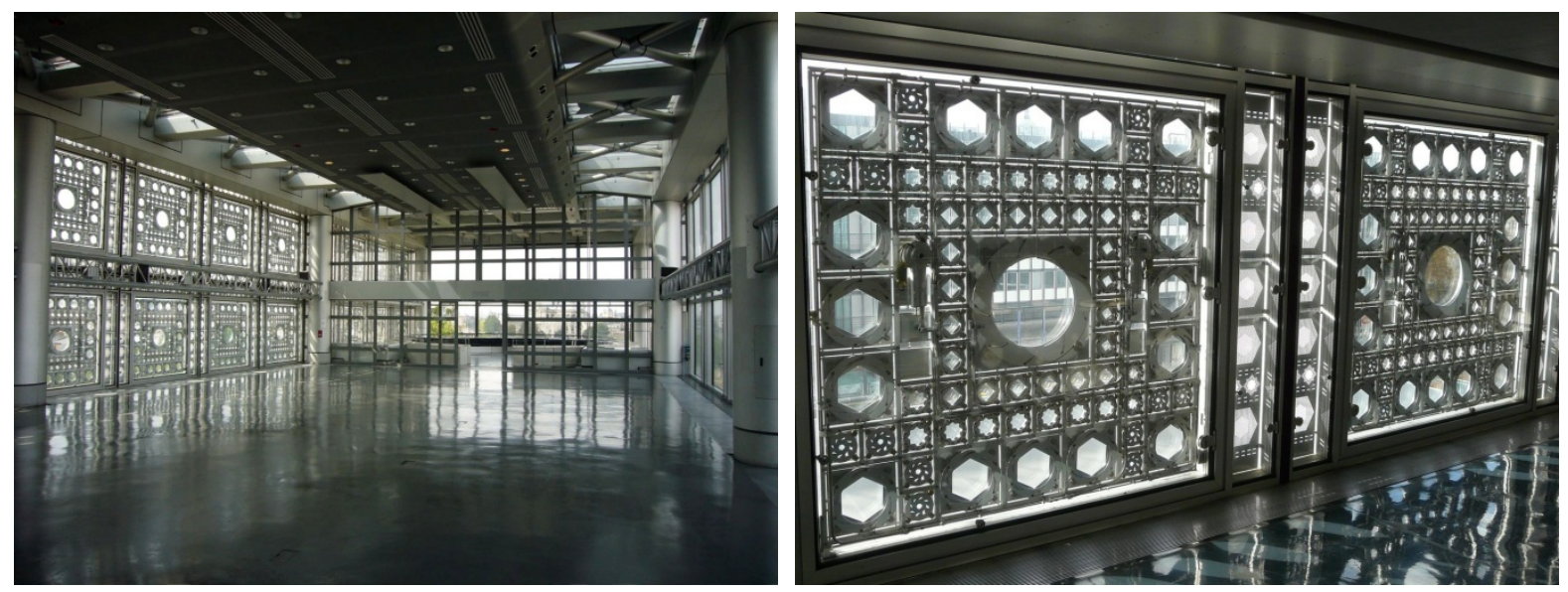

Сл.8.3.1- 1,2,3,4 „Arab World Institute / Enrique Jan + Jean Nouvel + Architecture-Studio“, Париз, Франција, 1988.

\section{„Kiefer Technic Showroom / Ernst Giselbrecht + Partner, Bad Gleichenberg“, Австрија, 2007 [55] \\ Оваа канцелариска зграда има динамична фасада која овозможува} оптимизирање на климата во внатрешноста, дозволувајќ им на корисниците преку соодветни контролни уреди да ги персонализираат просториите. Фасадата ја формираат алуминиумски панели кои функционираат како електронски ролетни.
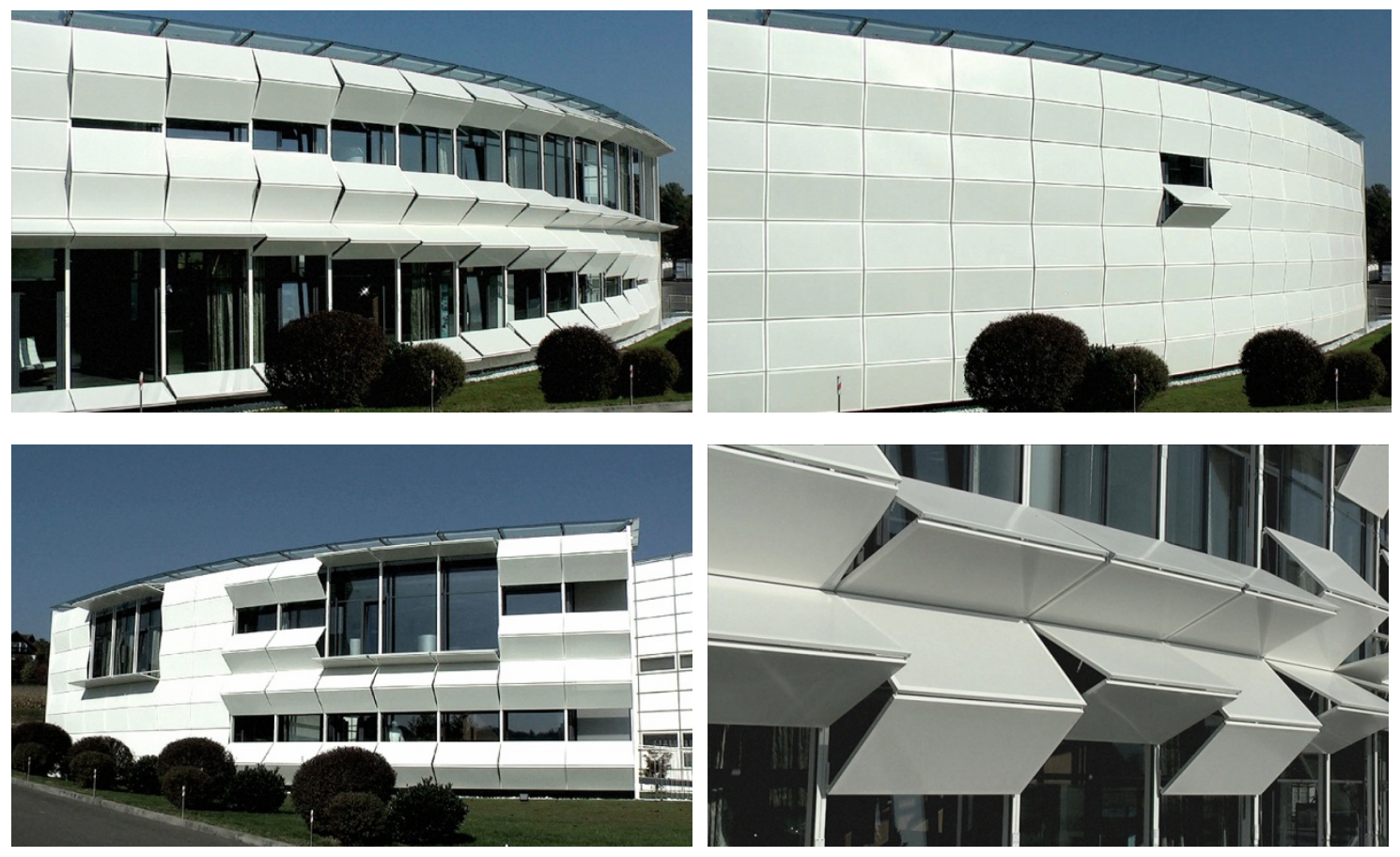

Cл.8.3.1- 5,6,7,8 „Kiefer Technic Showroom / Ernst Giselbrecht + Partner, Bad Gleichenberg “, Aвcmpuja, 2007. 


\section{„Al Bahar Towers Responsive Facade / Aedas“, Абу Даби, Обединети Арапски Емирати, 2012 [56]}

На место како Абу Даби, каде временските услови знаат да бидат екстеремни, со високи температури, интензивна сончева светлина и без дожд, потребата од објекти со динамични фасади е зголемена. Овие кули се дизајнирани со динамична обвивка од триаголни панели покриени со слој од фиберглас кои го менуваат аголот на наклон соодветно на надоврешната светлина, а на тој начин ја намалуваат соларната енергија кога влегува во објектот до $20 \%$.

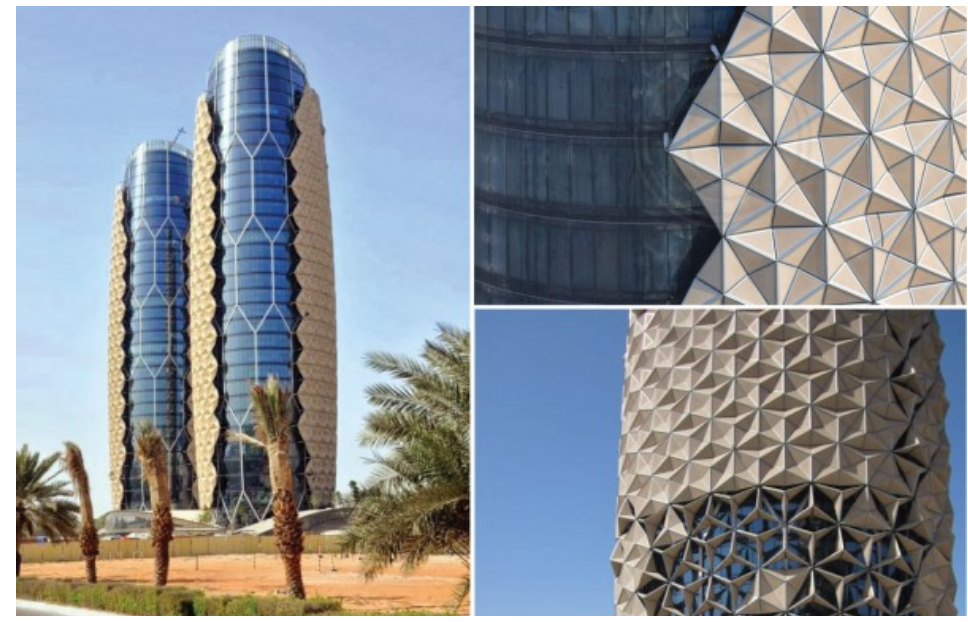

Сл.8.3.1- 9 „Al Bahar Towers Responsive Facade / Aedas", Абу Даби, Обединети Арапски Емирати, 2012.

\section{„SDU Campus Kolding / Henning Larsen Architects“, Колдинг, Данска, 2014 [57]}

Овој објект има динамична фасада која се прилагодува на сончевата светлина за да креира оптимални внатрешни услови. Системот за сончево засенување се состои од околу 1600 триаголни форми од перфориран лим кои се монтирани на фасадата на начин кој им дозволува отворање и затворање согласно со надворешните услови.
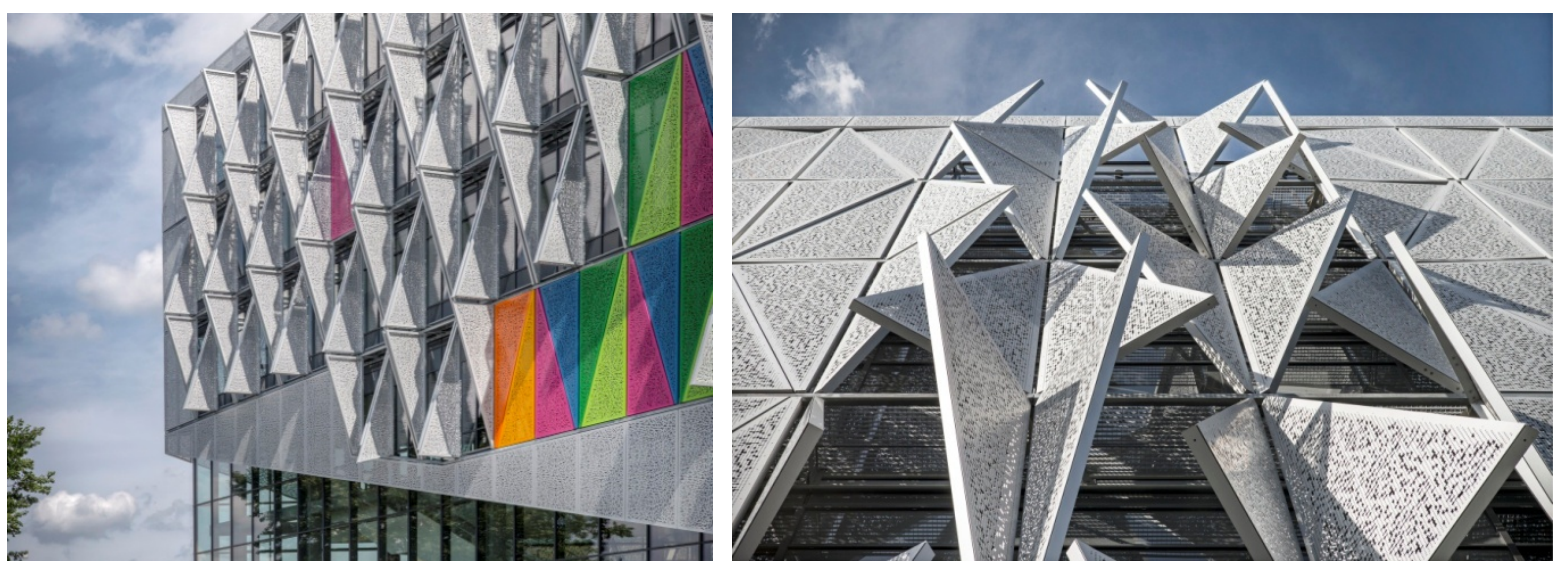

Сл.8.3.1- 10,11 „SDU Campus Kolding / Henning Larsen Architects", Колдинг, Данска, 2014. 


\section{4 ЕКОЛОШКО ПРОИЗВОДСТВО НА ЕЛЕКТРИЧНА ЕНЕРГИЈА}

Кога се работи за оптимално користење на сончевите зраци, тука се наметнува и потребата од користење на сончевите зраци за производство на електрична енергија. Поради тоа што како потреба постои поставувањето на единици во павиљонот за приклучување на електрични уреди, како и осветлување во вечерните часови, соодветно еколошко решение за снабдување на објектот со доволно количество на електрична енергија е поставување на сончеви панели.

Главен дел на еден ваков фотоволтаичен систем е PV модулот. PV модулот, изработен од полуспроводнички ќелии, генерира напон во зависност од нивото на сончево зрачење. Со помош на енергетска електроника, добиената еднонасочна струја од модулот се преобразува во наизменична за да може да се предаде во мрежата. Во Република Македонија постои доволно висок сончев потенцијал, односно сончево зрачење, за до соларните панели да стигнуваат доволно директни и дифузни сончеви зраци кои би овозможиле еден ваков павиљон да биде енергетски самоодржлив. Морфолошко - географските карактеристики на Македонија овозможуваат навлегување на топли и суви воздушни струења од југоисток, а освен тоа, јужната положба на Македонија и релативно малата облачност овозможуваат да пристигнува значително количество на сончева енергија. Вкупното годишно сончево зрачење варира од минимум $1250 \mathrm{kWh} / \mathrm{m}^{2}$ во северниот дел, до максимум 1530 $\mathrm{kWh} / \mathrm{m}^{2}$ во југозападниот дел, што доведува до просечно годишно сончево зрачење од $1385 \mathrm{kWh} / \mathrm{m}^{2}$. Годишниот просек за дневното зрачење варира помеѓу 3,4 kWh/m2 во северниот дел на земјата (Скопје) и 4,2 kWh/m2 во југозападниот дел (Битола). Климатските карактеристики - висок интензитет на сончево зрачење како и неговото времетраење, температурата, влажноста, овозможуваат поволни услови за успешниот развој на искористување на сончевата енергија. Континенталната клима со жешки и суви лета ја прави Македонија земја со повисок потенцијал за искористување на сончевата енергија од просечните Европски земји [58].

Врз основа на гореспоменатите податоци, како и спроведените истражувања, како заклучок може да се изведе дека генерираниот дизајн на павиљон би требало да вклучува можност за поставување на панели за производство на електрична енергија и тоа најмалку 6 соларни панели од 150W како и соодветна дополнителна опрема која тие ја налагаат за нивно функционирање - 1 контролер за полнење од 30A, 2 акумулатори 12V/220Ah и 1 инвертер $24 \mathrm{~V}$.

\section{5 АКУМУЛАЦИЈА НА ВОДА}

Со цел павиљонот да биде максимално еколошки, се јави идеја истиот да има дополнителна функција на колектирање дождовна вода. Бидејќи опкружувањето на самиот павиљон треба да биде природно и да изобилува со хортикултурни единици, за нивно одржување е потребна редовна грижа и наводнување. Преку соодветно оформување на настрешницата на павиљонот возможно е собирање до $80 \%$ од дождовната вода која паѓа врз него во текот на едно невреме. Според истражувањата, кровот на една просечна куќа со димензии 7 на 12 метри отфрла до 2300 литри на вода при паѓање на умерен дожд. Во истиот тој дом, дури 40\% од вкупната потрошувачка на вода оди на системите за наводнување на нејзиниот двор. Овие факти јасно 
покажуваат кое би било значењето на поставување системи за собирање вода. Преку собирање на дождовна вода со специјален дизајн на кровот на павиљонот кој ќе дозволува слевање на дождовните капки во специјализирани цевки и нивно колектирање во подземен резервоар за подоцна да бидат пренаменети за наводнување на околниот парк, овој павиљон ќе овозможи значителна заштеда на вода и трошоци за наводнување и ќе ја оствари целосно својата еколошка функција.

Принципите на рационално користење на вода може да се воочат во природните еко системи, особено во тропските предели каде високите дневни температури значат дека живите организми мораат максимално да ја користат дождовната вода. Сите живи организми во една тропска шума работат заедно и се во меѓусебна врска за да го оддржат нивното постоење. Животните зависат од дрвјата за храна, засолниште и заштита, додека дрвјата зависат од животните, помалите растенија и микроорганизмите за добивање хранливи материи. Бромелиадите играат важна улога во шумите бидејќ формираат мали оази сместени во центарот на нивните крошни со што привлекуваат многу живи организми кои пијат од водата или живеат во тој резервоар. Овие растенија обезбедуваат витална вода за низа видови животни, а за возврат отпадот и труповите од тие животни ги снабудуваат со хранливи материи. Начинот на кој овие растенија собираат вода е преку формацијата на листовите и нивниот спирален распоред кој креира еден вид на централна чашка што може да складира вода како во мал базен без таа да протекува [61,62].
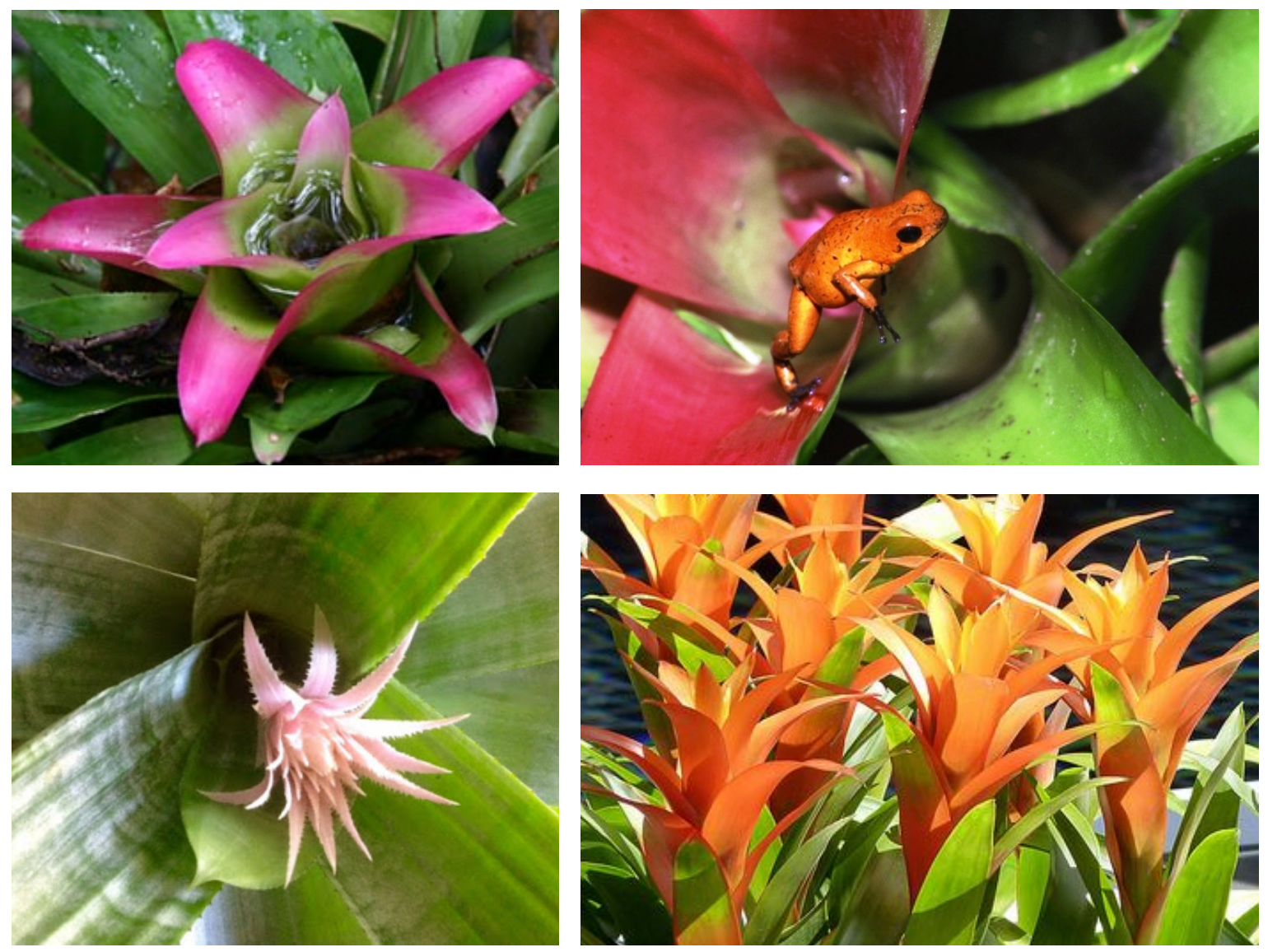

Сл.8.5- 1,2,3,4 Формација на листови и акумулација на вода кај бромелиадите. 


\section{6 КОНЦЕПТИ}

Врз основа на досега споменатото, беа разработени неколку концептни решенија за павиљонот. Истите се објаснети понатаму преку илустрации, макети и коментари. Концептите се однесуваат на основната форма и функција на павиљонот, со цел да се одбере насјсоодветното решение за изглед на павиљонот, а потоа истото да се доработи со поставување на урбана опрема, предвидување на отворени и затворени делови, поставување на динамична фасада, предвидување места за полнење на електрични уреди и сл.

\subsection{1 Концепт 1}

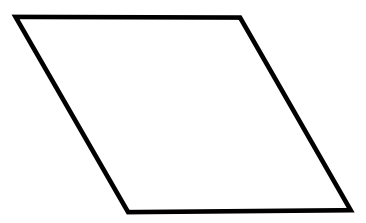

ОСНОВЕН ЕЛЕМЕНТ

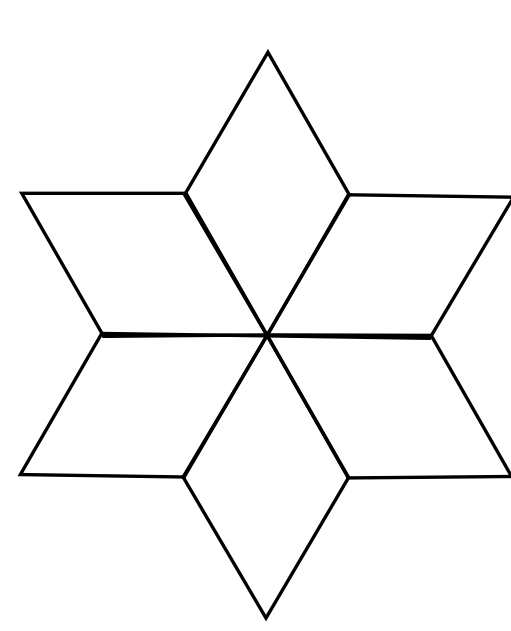

модул

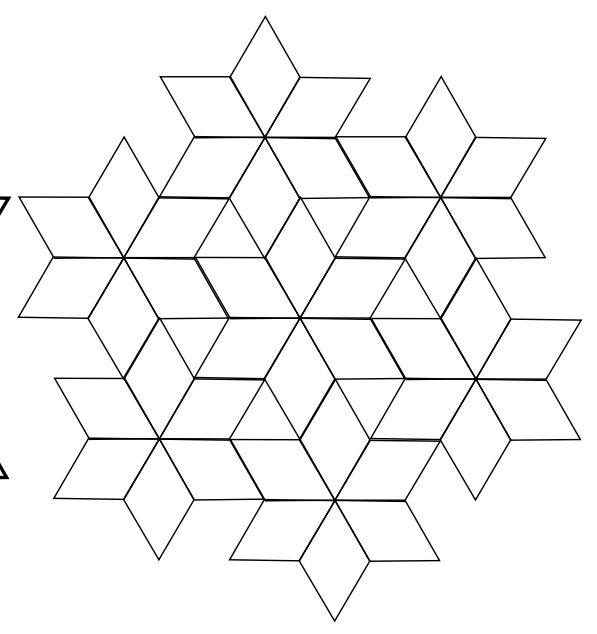

МУЛТИПЛИКАЦИЈА

Сл. 8.6.1-1 Приказ на модуларноста кај Концепт 1.

Кај првиот концепт беше разгледана можноста за модуларност која ја има ромб со остри агли од $60^{\circ}$. Оваа едноставна форма нуди многу можности за нејзино комбинирање и умножување, па истата би била соодветна за примена како основа на павиљонот. Секој од ромбовите од основата на павиљонот би содржел одредена урбана опрема, а радијалното спојување на 6 вакви ромбоидни форми би го оформило главниот модул. Дополнително, ваквата полигонална форма на кровот на павиљонот значи дека полигоните може да бидат накривени под одреден агол со цел да се постигне можност за поставување на сончеви колектори како и да се насочи слевањето на дождовна вода. 


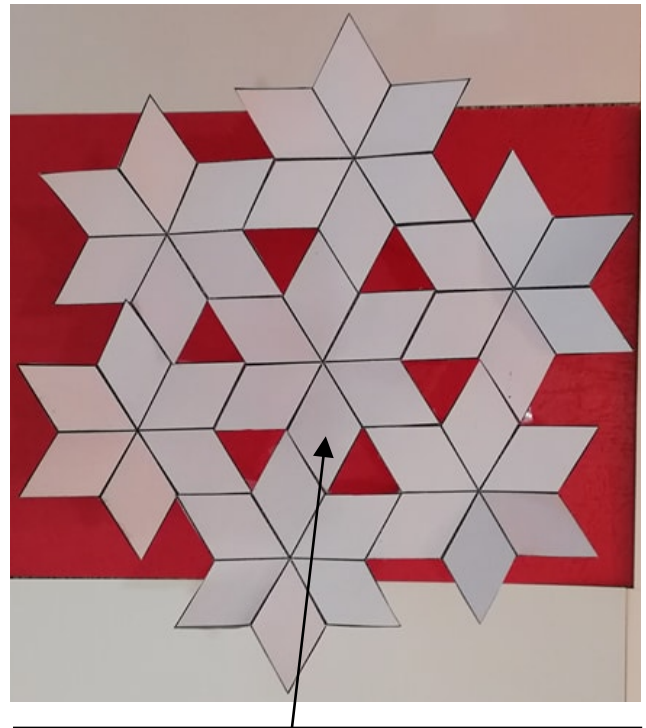

МОЖНОСТ ЗА ПОСТАВУВАҢЕ НА СОНЧЕВИ КОЛЕКТОРИ НА КРОВНИТЕ ПАНЕЛИ НА ЦЕНТРАЛНИОТ МОДУЛ

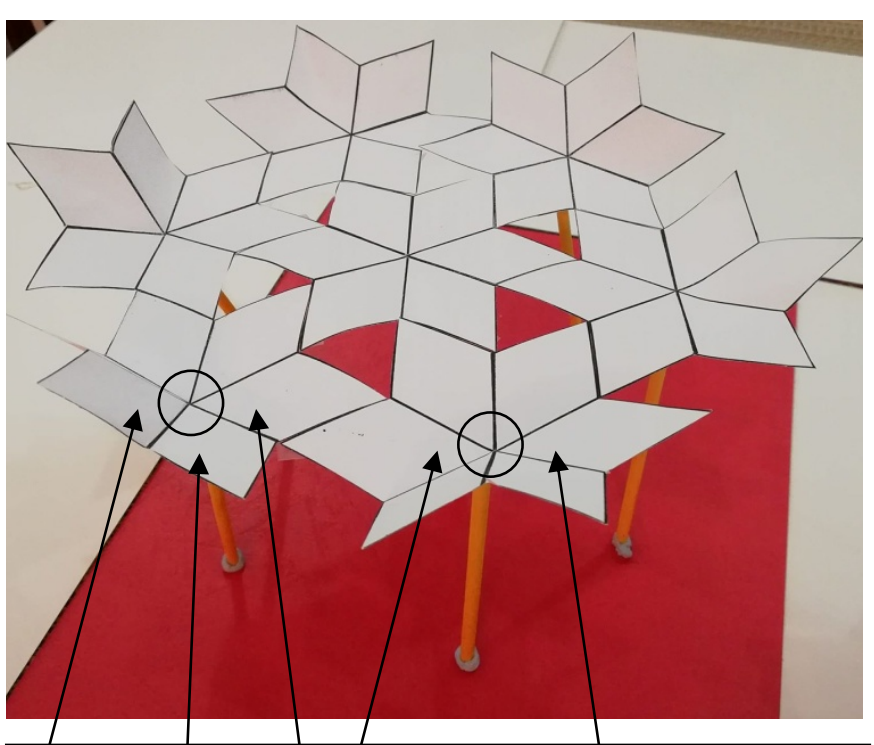

НАКРИВУВАЊА НА КРОВНИТЕ ПАНЕЛИ ПОД ОДРЕДЕН АГОЛ ЗА НАСОЧЕНО СЛЕВАҢЕ НА ДОЖДОВНА ВОДА КОН ЦЕНТАРОТ

Сл. 8.6.1-2,3 Макета на Концепт 1.

\subsection{2 Концепт 2}

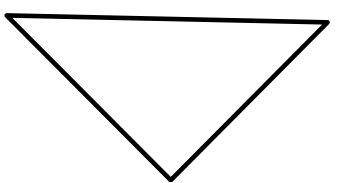

ОСНОВЕН ЕЛЕМЕНТ

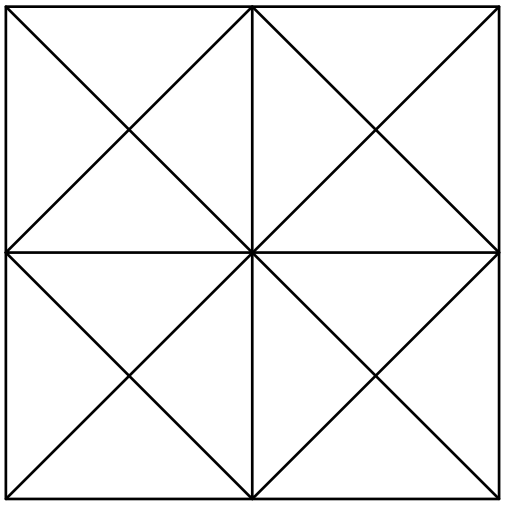

Модул

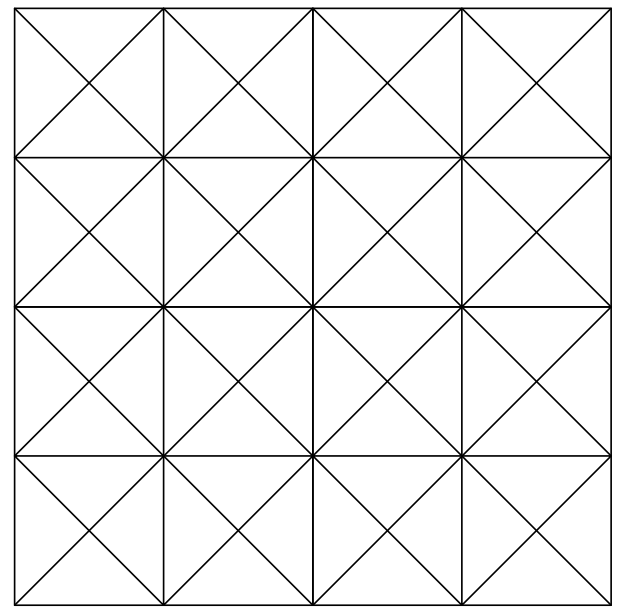

МУЛТИПЛИКАЦИЈА

Сл. 8.6.2-1 Приказ на модуларноста кај Концепт 2.

Вториот концепт ги истражува модуларните можности на правоаголен триаголник мултиплициран 16 пати за да го креира основниот модул на павиљонот чие надоврзување би значело зголемување на квадратурата на просторот. Овој концепт, како и претходниот, е базиран на полигонален, оригами систем, а тоа значи дека за кровот на павиљонот да ја постигне својата тродимензионалност овие триаголни панели би требало да се изротираат под одреден агол. Ваквата положба би овозможила дополнителна функција за поставување на сончеви панели каде што има можност и за насочување на дождовната вода кон канали за нејзино слевање и подземно складирање. 


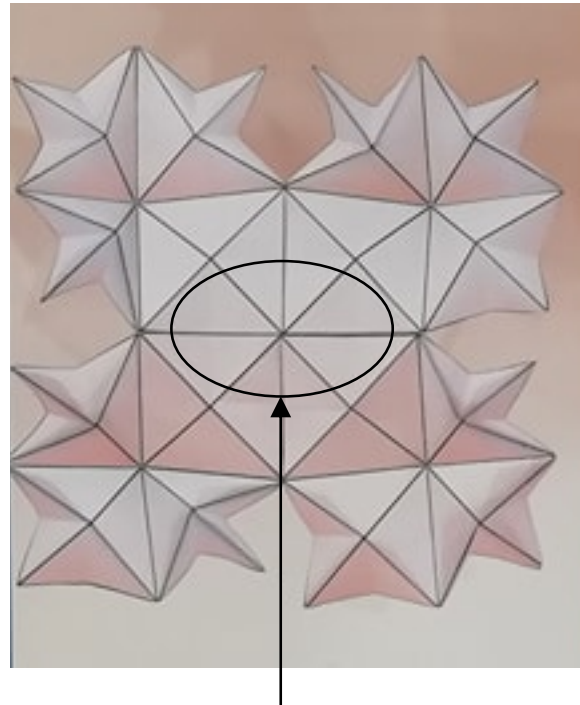

ПРИ НАДОВРЗУВАҢЕ НА МОДУЛИТЕ ЦЕНТРАЛНИОТ КРОВЕН ДЕЛ КАДЕ ШТО ТИЕ СЕ СПОЈУВААТ БИ БИЛ НАМЕНЕТ ЗА ПОСТАВУВАҢЕ НА СОНЧЕВИ КОЛЕКТОРИ

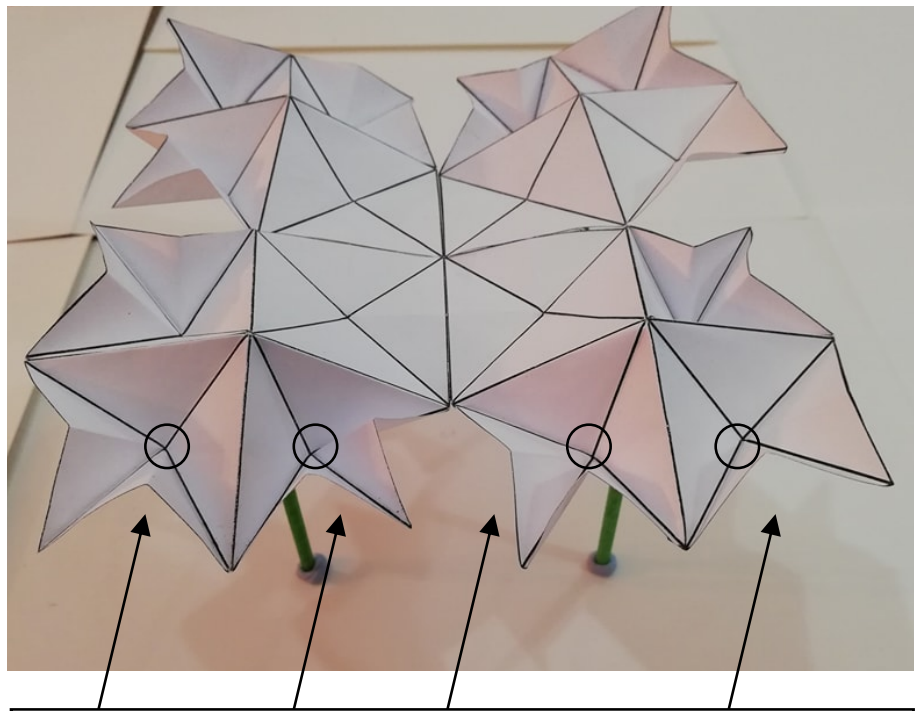

СТРАНИЧНИТЕ, КРАЈНИ ТРИАГОЛНИ ПАНЕЛИ БИ БИЛЕ ЗАКРИВЕНИ ПОД СООДВЕТЕН АГОЛ ЗА ДА МОЖЕ ДА ЈА НАСОЧУВААТ ДОЖДОВНАТА ВОДА ЗА ТАА ДА СЕ СЛЕВА НИЗ СООДВЕТНИ КАНАЛИ

Сл. 8.6.2-2,3 Макета на Концепт 2.

\subsection{3 Концепт 3}

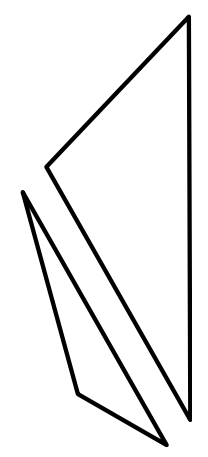

ОСНОВЕН ЕЛЕМЕНТ

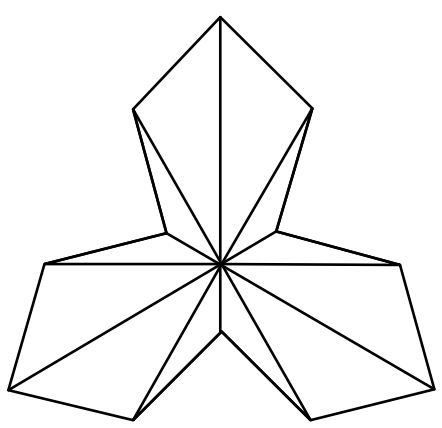

модул

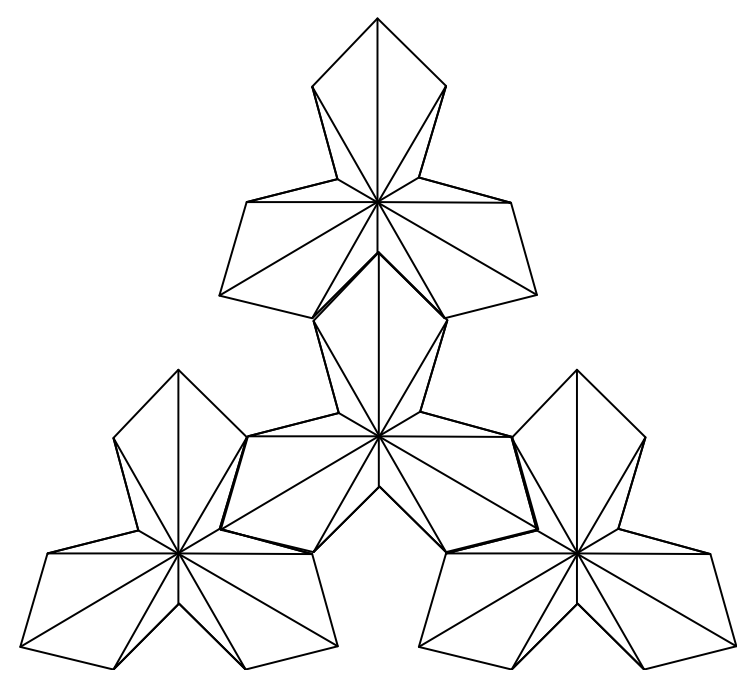

МУЛТИПЛИКАЦИЈА

Сл. 8.6.3-1 Приказ на модуларноста кај Концепт 3.

Третата форма предложена како концептно решение е постигната преку надоврзување на 2 вида триаголни форми во вид на краци кои со радијално копирање, 3 пати, под агол од $120^{\circ}$ го креираат основниот модул. За мултиплицирањето да биде возможно беше важно сите страни да бидат еднакви по должина и аглите на триаголниците да овозможуваат вклопување еден во друг. Вака креираните модули може да се надодаваат едни на други од сите страни за да се зголемува основата. Формирањето на кровот е слично како и кај претходните концепти, функцијата на собирање вода и поставување соларни панели е овозможена преку дефинирање на различни агли на кровните триаголни панели. 


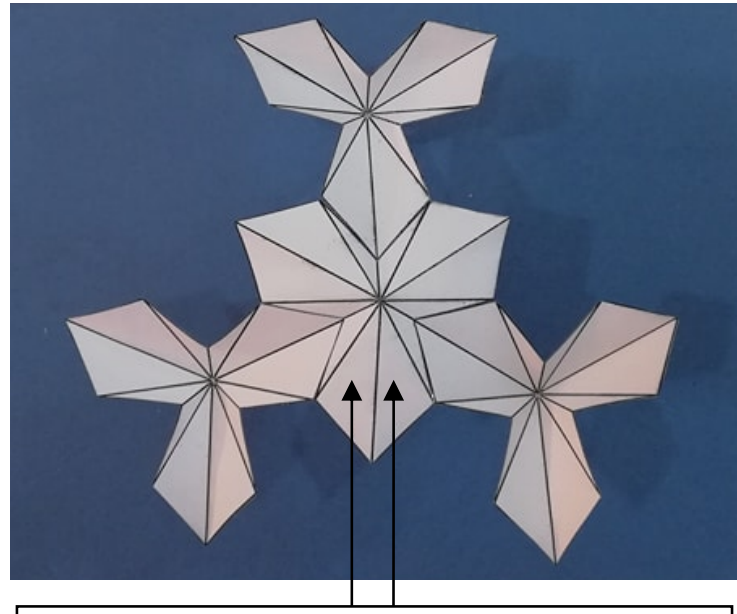

НАЧИН НА ПОВРЗУВАњЕ НА ЕЛЕМЕНТИТЕ

КРОВНИТЕ ПАНЕЛИ НА ЦЕНТРАЛНИОТ МОДУЛ БИ БИЛЕ ЗАКРИВЕНИ ВО ДОЛНА НАСОКА СО ЦЕЛ ТОЈ ДА БИДЕ ИСПАКНАТ И НА НЕГО ДА СЕ ПОСТАВАТ СОНЧЕВИТЕ КОЛЕКТОРИ ЗА ПРОИЗВОДСТВО НА ЕЛЕКТРИЧНА ЕНЕРГИЈА

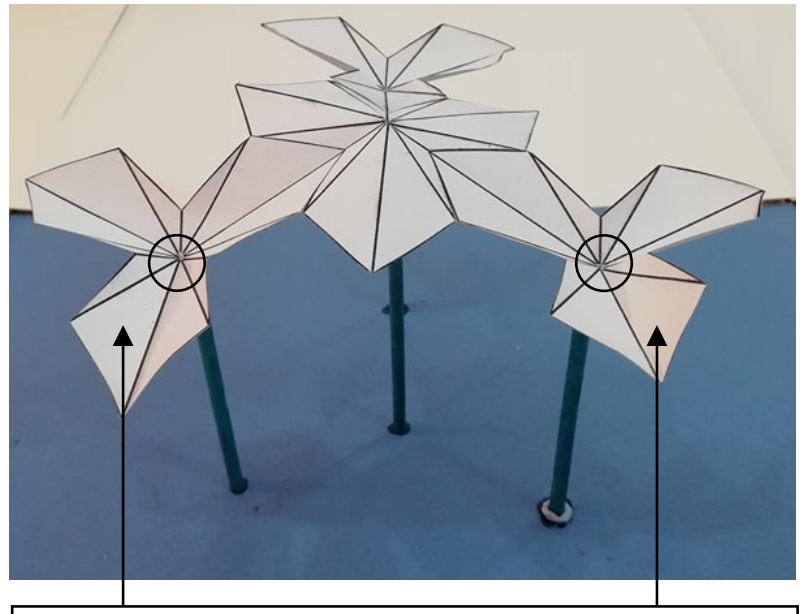

ОСТАТОКОТ ОД МОДУЛИТЕ НАДОВРЗАНИ ЗА ЦЕНТРАЛНИОТ БИ ИМАЛЕ ПАНЕЛИ НАКРИВЕНИ ВО ОБРАТНА НАСОКА СО ЦЕЛ ДА ФОРМИРААТ ВДЛАБНАТ ИЗГЛЕД ШТО К̈Е ПОМОГНЕ ВОДАТА ОД ДОЖДОВИТЕ ДА СЕ СЛЕВА КОН НИВНИОТ ЦЕНТАР ВО СООДВЕТНИ ДОЖДОВНИ КАНАЛИ

Сл. 8.6.3-2,3 Макета на Концепт 3.

\section{7 ОЦЕНУВАЊЕ НА КОНЦЕПТИ}

За оценување на концептите и избор на финален концепт за детална разработка најпрво беше употребена матрица на одлучување (Pugh метод) при што концептите беа оценети едни спрема други според нивната можност за задоволување на потребните барања. Дизајнерските барања беа соодветно преформулирани и означени според нивната важност (фактор на тежина од 1 до 16, каде 16 означува најголема важност, а 1 најмала), еден од концептите беше назначен како база, а останатите беа споредени со него како подобри во задоволување на барањата (+), полоши (-) или исти (S).

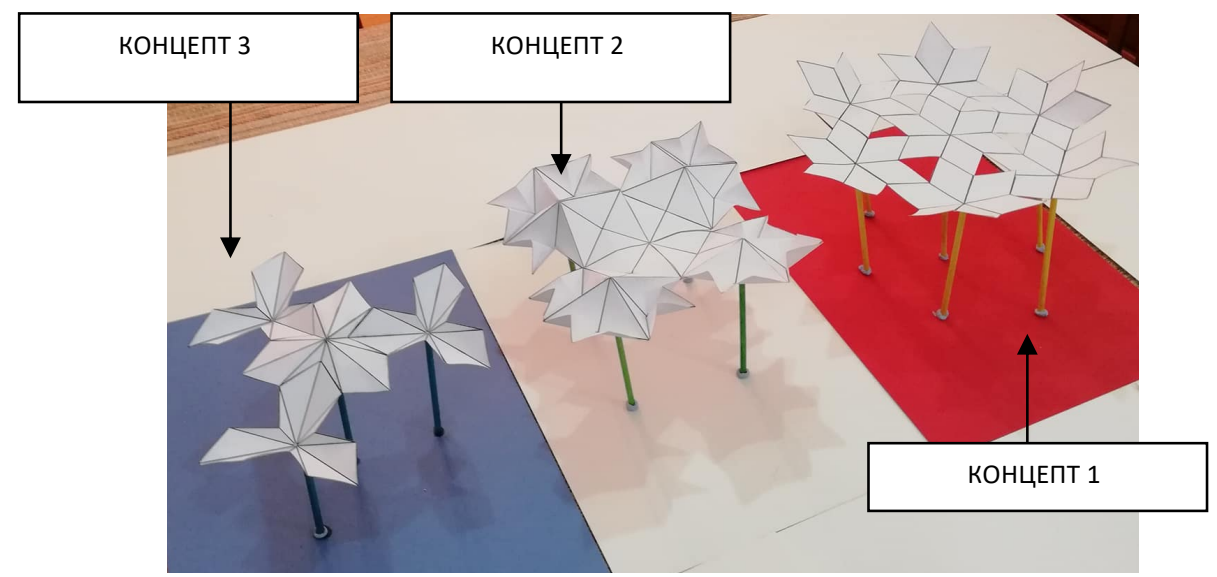

Сл. 8.7-1 Макети од сите 3 концепти. 


\begin{tabular}{|c|c|c|c|c|}
\hline & ФАКТОР & КОН.1 & КОН.2 & КОН.3 \\
\hline Заштита од лоши временски услови & 16 & \multirow{7}{*}{ Б } & $\mathbf{s}$ & $\mathbf{s}$ \\
\hline Заштита од сонце и отсјај & 15 & & $\mathbf{S}$ & $\mathbf{S}$ \\
\hline Добра осветленост & 14 & & S & S \\
\hline Добра вентилација & 13 & & $\mathbf{S}$ & $\mathbf{S}$ \\
\hline Можност за Wi-fi пристап & 6 & & $\mathbf{S}$ & $\mathbf{S}$ \\
\hline Можност за поставување приклучници & 7 & & $\mathbf{s}$ & $\mathbf{s}$ \\
\hline Мултифункционалност & 12 & & s & S \\
\hline Доволно простор & 11 & A & S & $\mathbf{S}$ \\
\hline Можност за приватност & 9 & \multirow{2}{*}{3} & S & S \\
\hline Удобност & 8 & & $\mathbf{S}$ & $\mathbf{S}$ \\
\hline Лесен пристап & 4 & \multirow[t]{6}{*}{ A } & $\mathbf{S}$ & $\mathbf{S}$ \\
\hline Лесна употреба & 5 & & S & S \\
\hline Привлечен дизајн & 3 & & - & + \\
\hline Добра модуларност & 10 & & - & + \\
\hline Добра врска со околината & 1 & & S & S \\
\hline Еколошки производ & 2 & & $\mathbf{s}$ & S \\
\hline \multicolumn{2}{|l|}{ ВКУПНО + } & 0 & 0 & 2 \\
\hline \multicolumn{2}{|l|}{ ВкУПНО - } & 0 & 2 & 0 \\
\hline \multicolumn{2}{|l|}{ ВКУПНО } & 0 & -2 & 0 \\
\hline \multicolumn{2}{|l|}{ СПОРЕД ВАЖНОСТ } & 0 & -13 & 13 \\
\hline
\end{tabular}

Taб. 8.7-1 Матрица на одлучување (Рugh метод) за оценување на концептите.

За дополнителна конторла на точноста на изборот е употребен уште еден метод на оценување на трите варијанти - метод на пајакова мрежа. Концептите беа оценети на скала од 0 до 3 според 10 издвоени релевантни критериуми. Варијантата со најголема плоштина на полигонот е онаа која најдобро би ја вршела својата функција. Резултатите се прикажани подолу. 


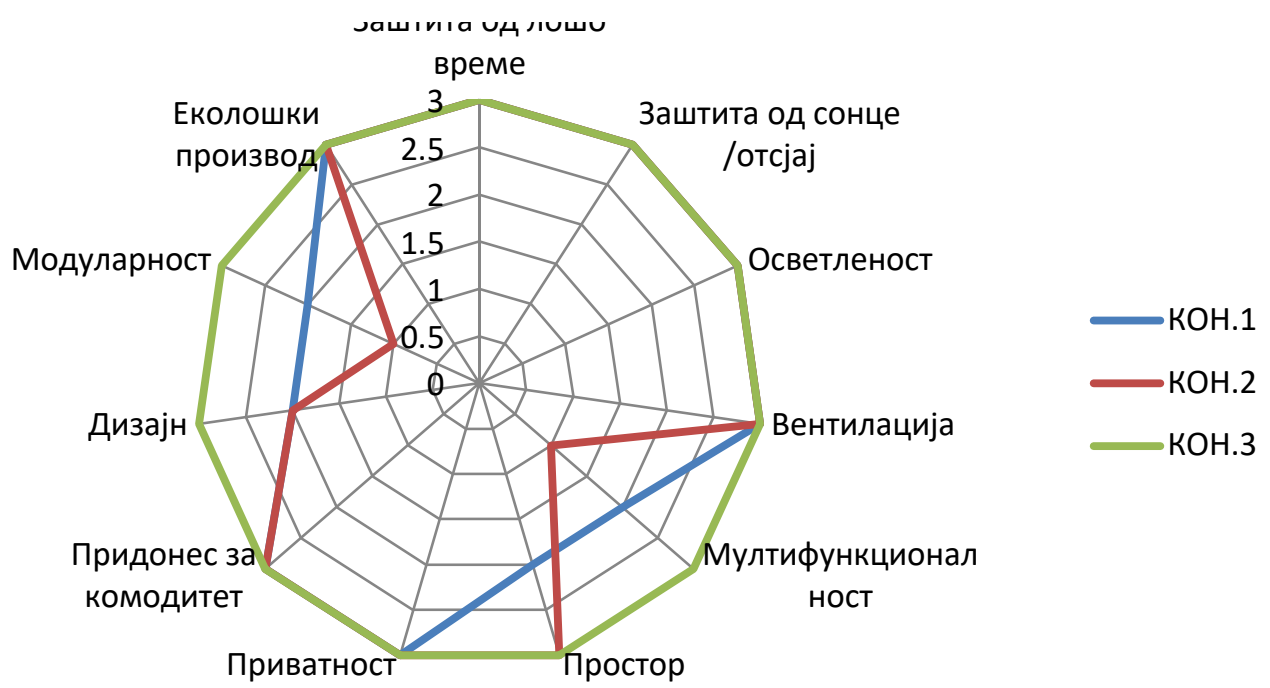

Граф. 8.7-1 Метод на пајакова мрежа за оценување на концептите.

По направената матрица на одлучување и метод на пајакова мрежа, јасно е дека сите предложени концепти би биле добри во задоволување на речиси сите значајани барања. Главните фактори на одлучување беа добрата модуларност на системот и привлечниот дизајн. Резултатот покажа дека вториот концепт, во однос на првиот, има послаби можности за модуларност. Тоа е така поради тоа што, во случај кога би било потребно надоградување на системот и додавање на дополнителни модули на веќе поставени модули во просторот, овој процес би бил отежнат заради потреба на менување на крајните елементи на модулите за на нив да може да се надоврзат други. Ова се јавува поради тоа што централниот дел на кровот мора да има различни агли на наклон заради поврзувањето на сегментите и поставувањето на соларни панели, додека страничните делови мора да се различни поради потребата од правилно вршење на функцијата колекција на вода за наводнување. Во однос на добрата модуларност, резултатите покажаа дека последниот концепт е најдобар. Тој има најдобра можност за континуирано надоврзување на модулите, без потреба од нивно изменување (како кај концепт 2) и без прекин на површините (како кај концепт 1 каде при надоврзување на модулите одредени сегменти во форма на триаголник остануваат празни). Токму поради добрата модуларност и компактноста, концепт 3 има и најпривлечен дизајн во однос на другите два. Поради сите напоменати фактори на одлучување, концепт 3 е избран како концепт за натамошна разработка. 


\section{9. ПРЕЗЕНТАЦИЈА НА ИДЕЈНО РЕШЕНИЕ}

\section{1 ЗД МОДЕЛ, ОБЈАСНУВАҢЕ НА ДЕТАЛИ}

Избраниот концепт беше понатаму разработен преку изработка на ЗД модел во софтверот SolidWorks. Павиљонот е дизајниран како систем од поврзани модули кои ги задоволуваат потребните функционални карактеристики кои беа претходно дефинирани. Клучниот аспект е дека вака дизајнираните компоненти може да се комбинираат и надополнуваат според просторот и според намената и потребите на помал или поголем број на корисници. Останатиот дел од дизајнот се развиваше постепено, преку надоградување на елементите. Најпрвин се дефинираше начинот на изведба на кровот, потоа изгледот на носечките столбови, изгледот на внатрешниот мебел и неговата поставеност во внатрешноста, како и изгледот на динамичните панели. Конечниот изглед кој се доби е модерен и динамичен, преку употребата на аглести форми и следење на оригами трендот [64] во дизајнот.
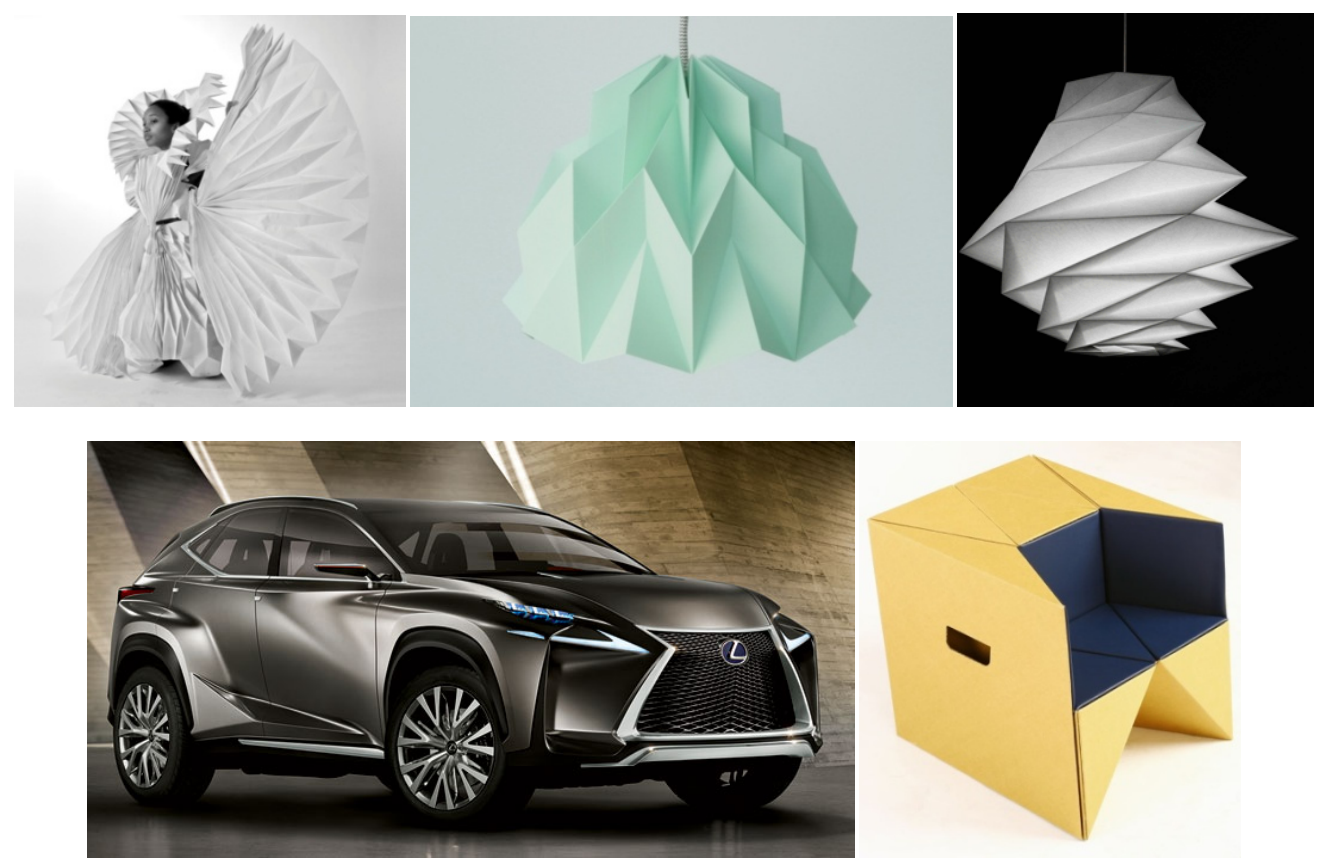

Сл. 9.1-1,2,3,4,5 Примена на оригами трендот при дизајн на различни производи.
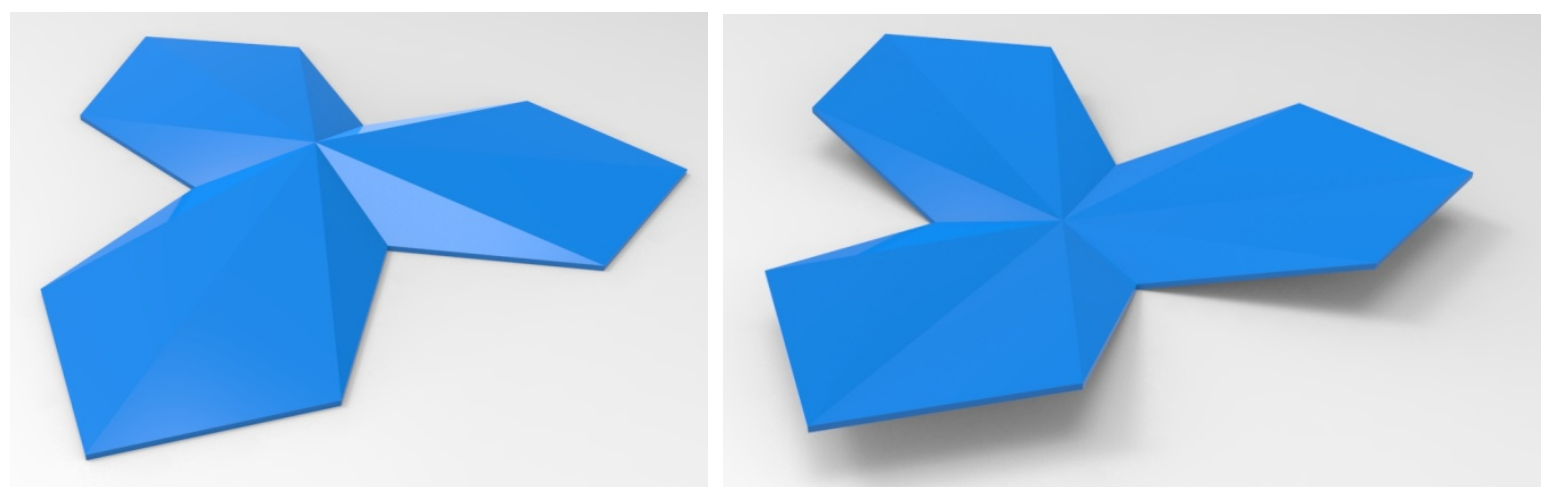

Сл. 9.1-6,7 Почетна фаза на моделирање - дефинирање на изгледот на кровот на модулите. 


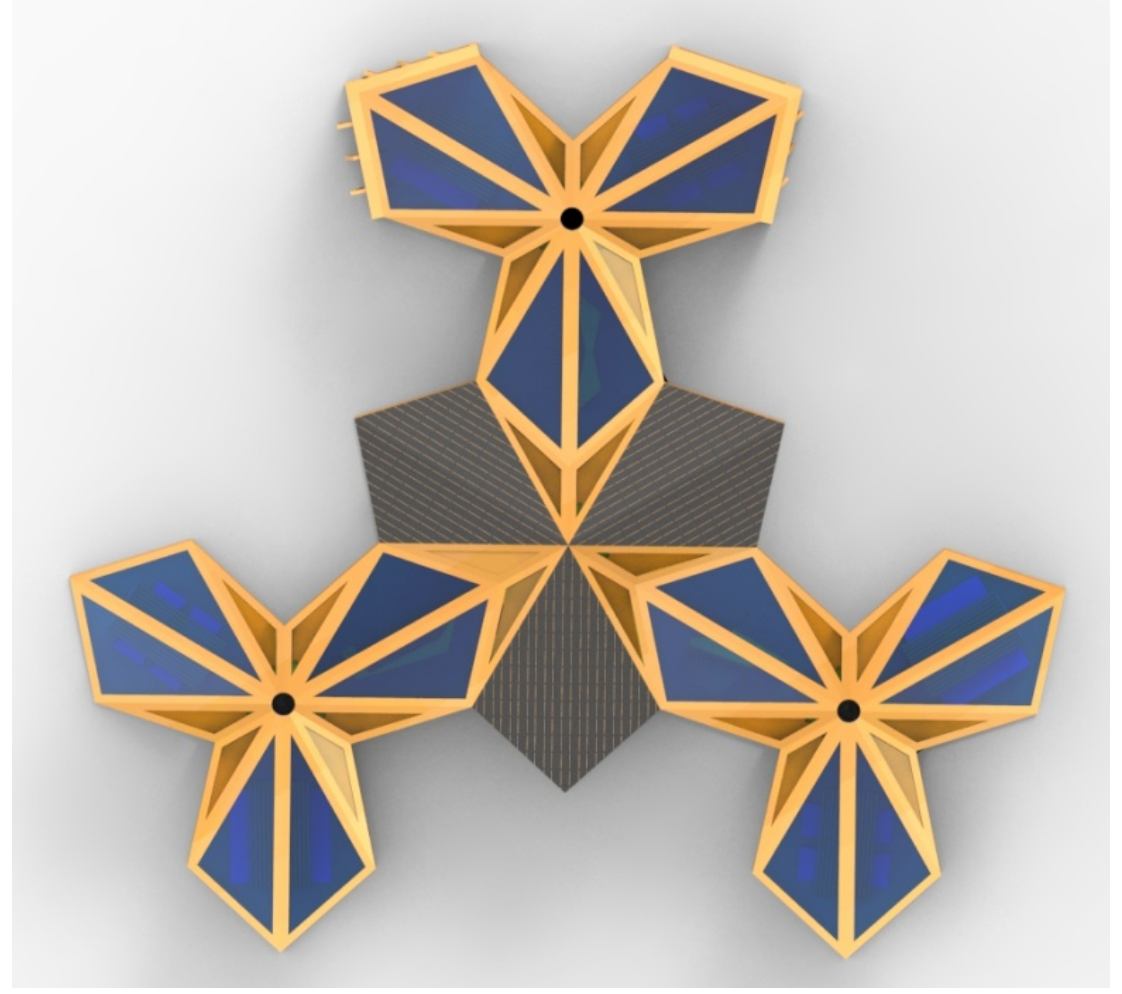

Сл. 9.1-8 Дефинирање на изгледот на кровот како транспарентни панели сместени во дрвена рамка. Тестирање на модуларноста на системот. Поставување на соларни панели и цевки за слевање и акумулација на дождовна вода.

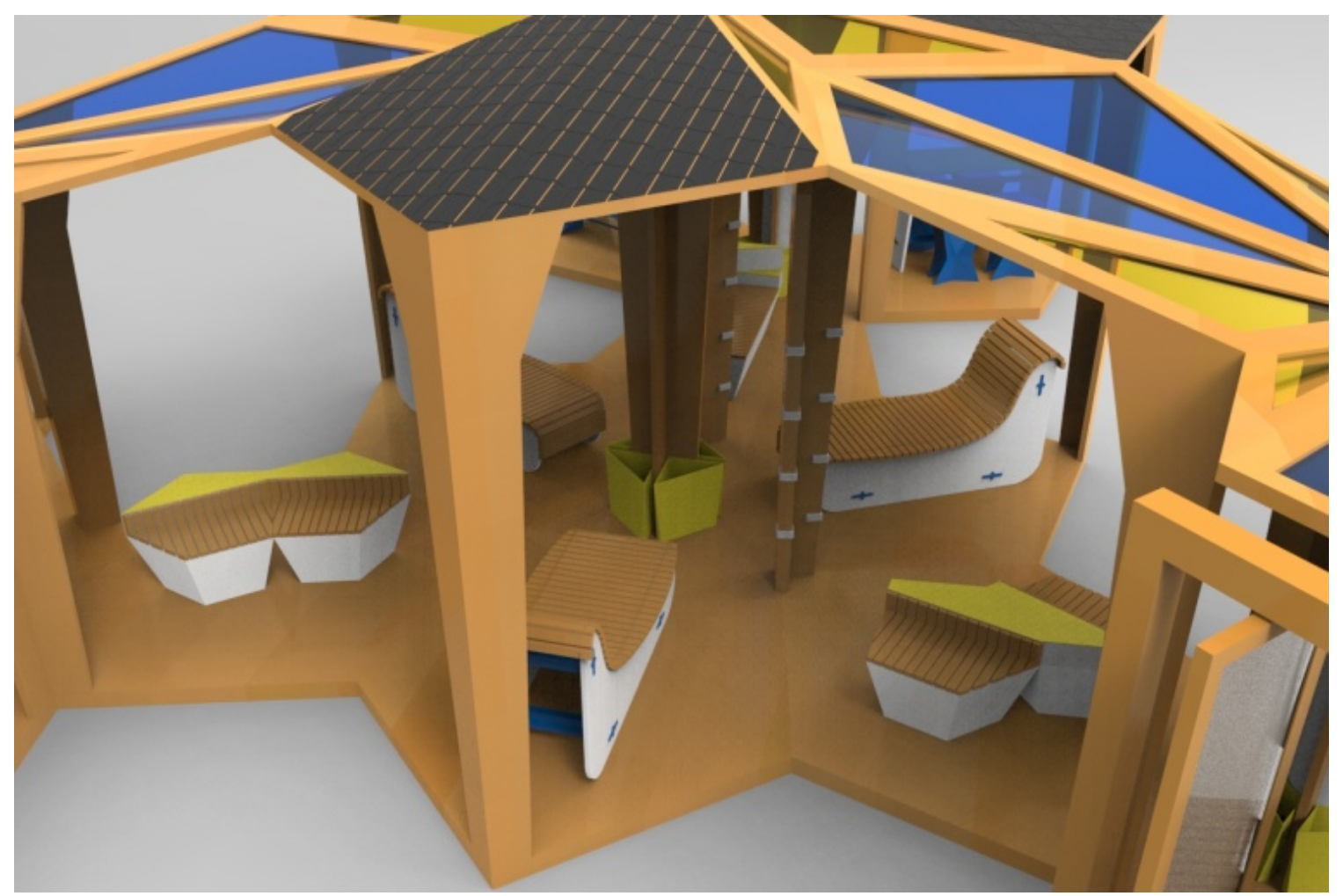



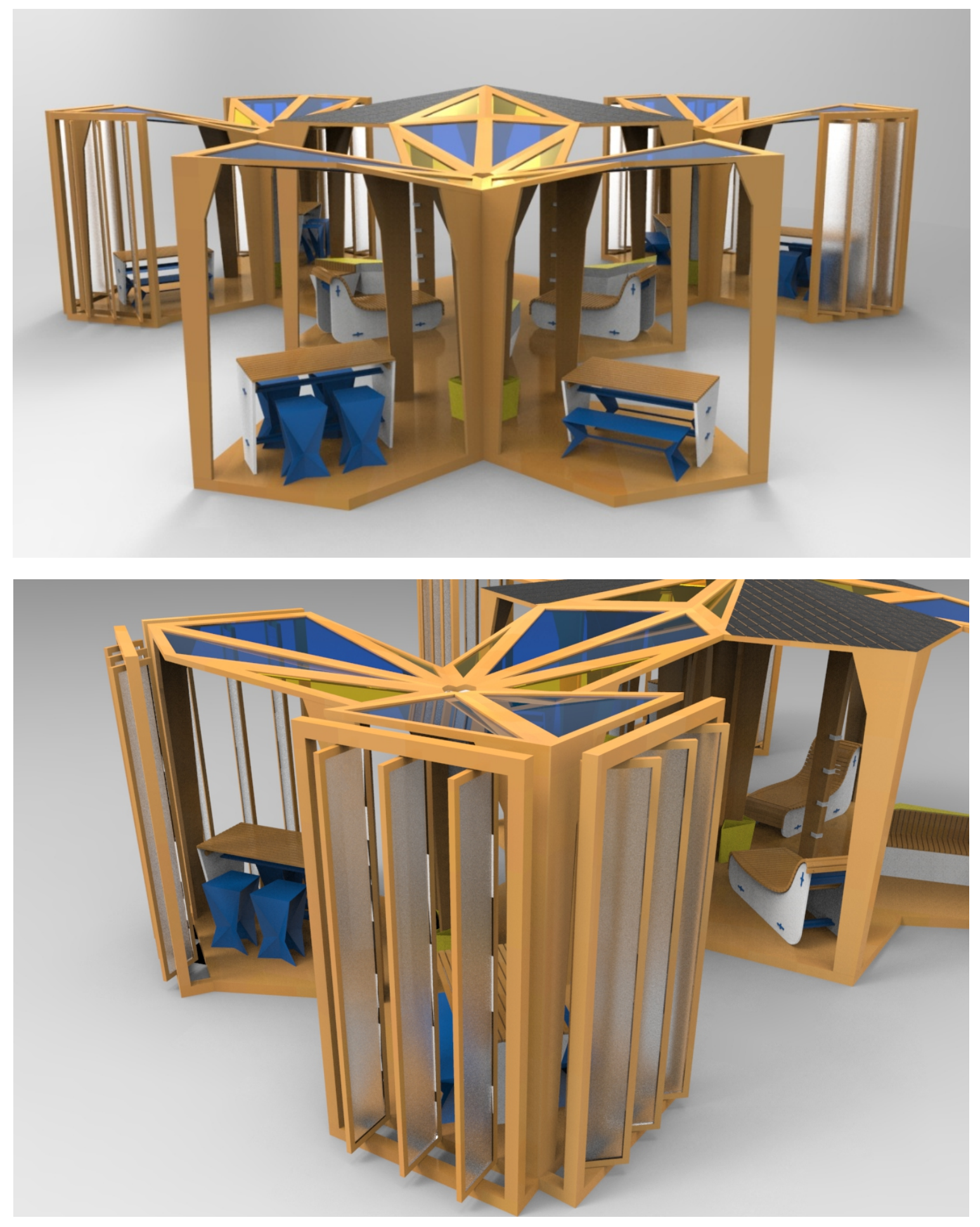

Сл. 9.1-9,10,11 Почетна идеја за изведба на носечките дрвени столбови, изгледот на ротирачките панели и мебелот во ентериерот на павиљонот. 

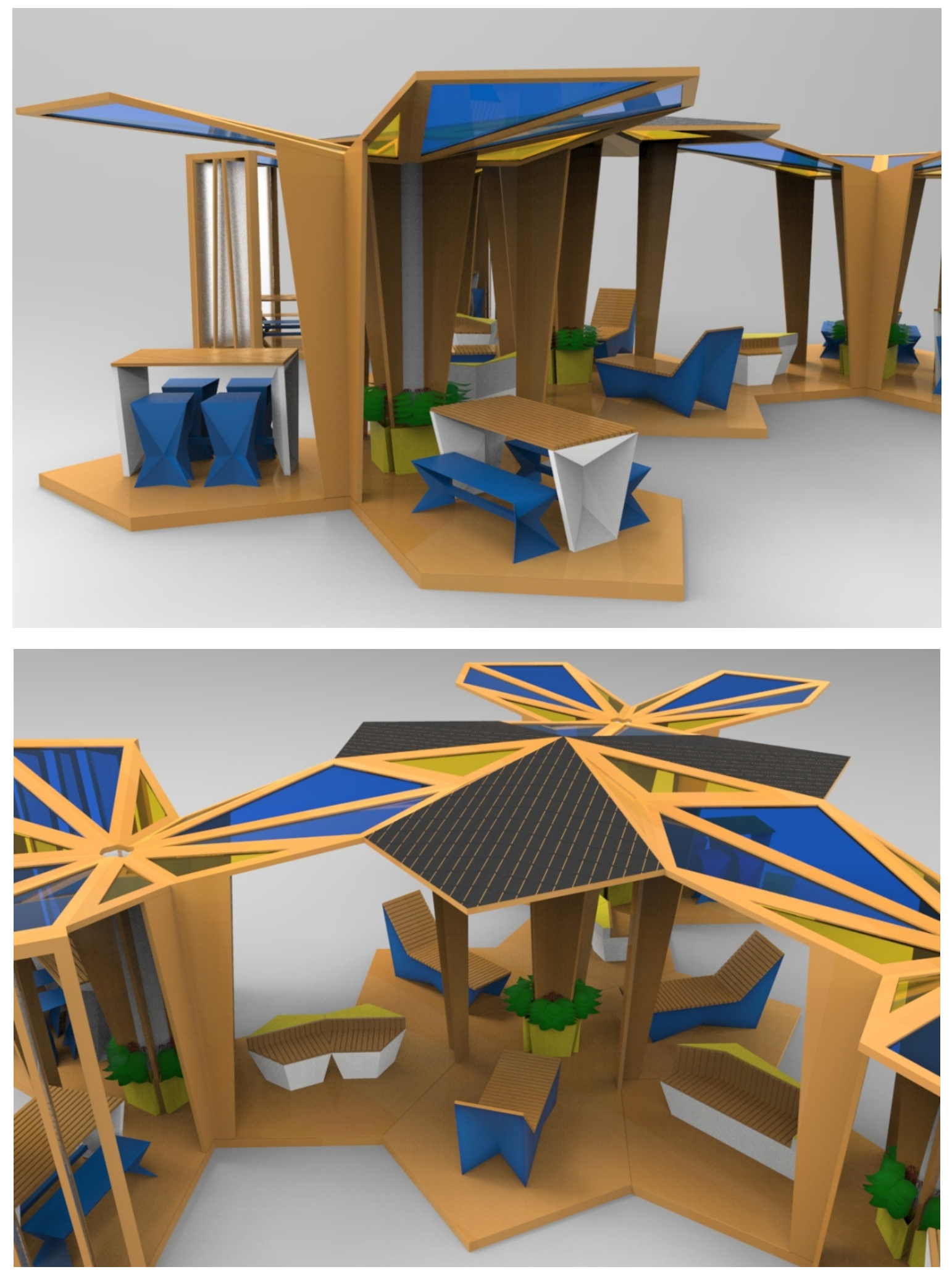

Сл. 9.1-12,13,14 Развој на идејата и добивање на конечен дизајн на павиљонот - со коси носечки столбови и мебел целосно дизајниран во оригами стил за да соодветствува на екстериерот. 

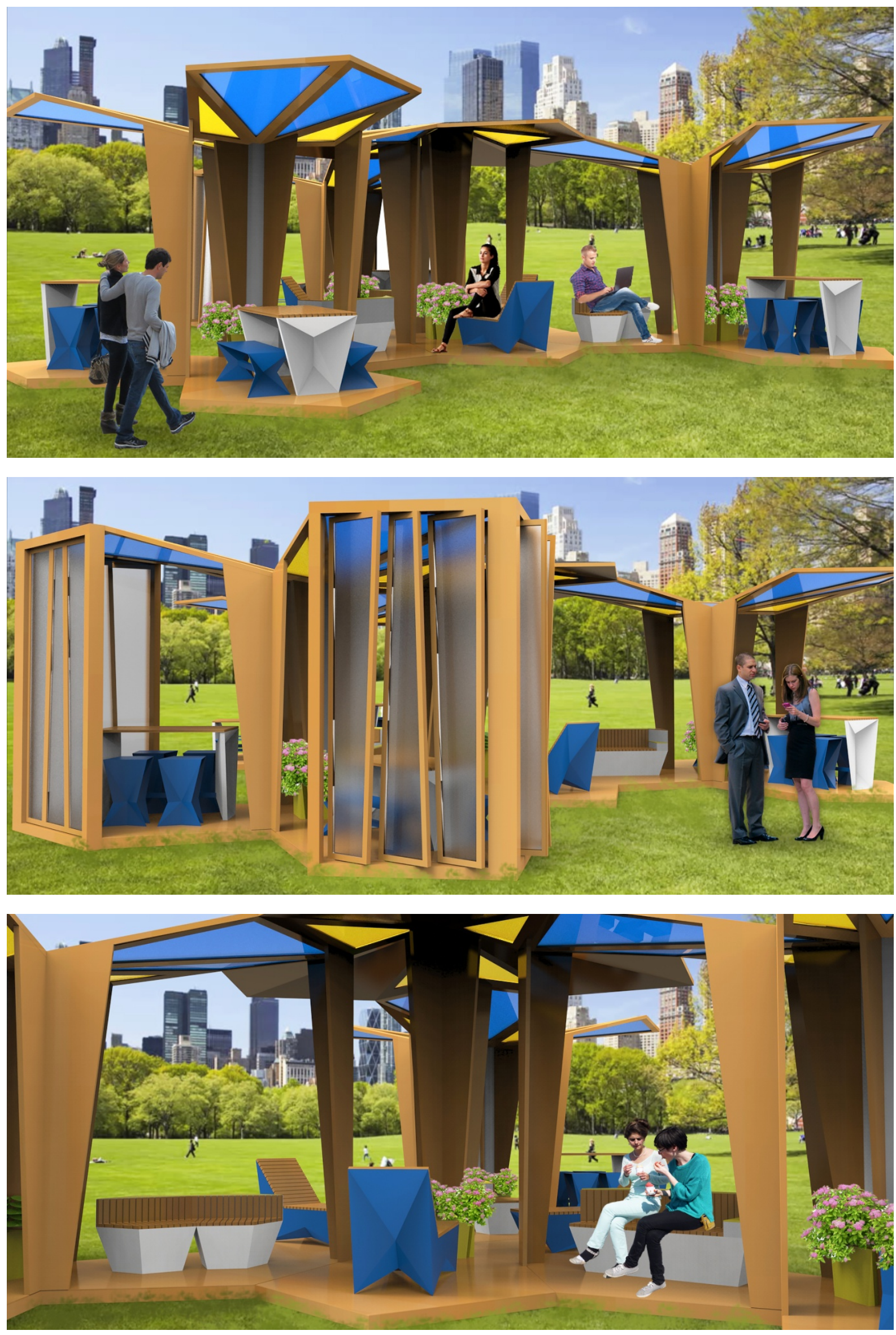

Сл. 9.1-15,16 Конечен изглед на павиљонот и негова визуелизација во природна средина со корисници. 
Идејата поврзана со еколошката функција на самиот павиљон беше реализирана на повеќе начини. Најпрво, кровот на секој од модулите е соодветно дизајниран за да врши одредена функција. Кровот на централниот е составен од триаголни форми поставени под остри агли едни во однос на други, а останатите модули се составени од триаголни форми под тап агол. Ваквото оформување овозможува слевање на водата и нејзино насочување кон вдлабнатите делови (во центарот на крововите на модулите поставени околу централниот) каде се наоѓa отвор и цевка што поминува низ внатрешниот волумен на павиљонот и завршува во подземен резервоар за складирање на дождовна вода од каде истата би била пренаменета за наводнување. Дополнително, триаголните форми под остар агол на кровот на централниот модул се осмислени за на нив да бидат поставени 6 соларни панели кои би биле доволни за задоволување на енергетските потреби на павиљонот. Насочувањето на електричната енергија е до сите приклучоци за електронски уреди во внатрешноста на самиот павиљон.

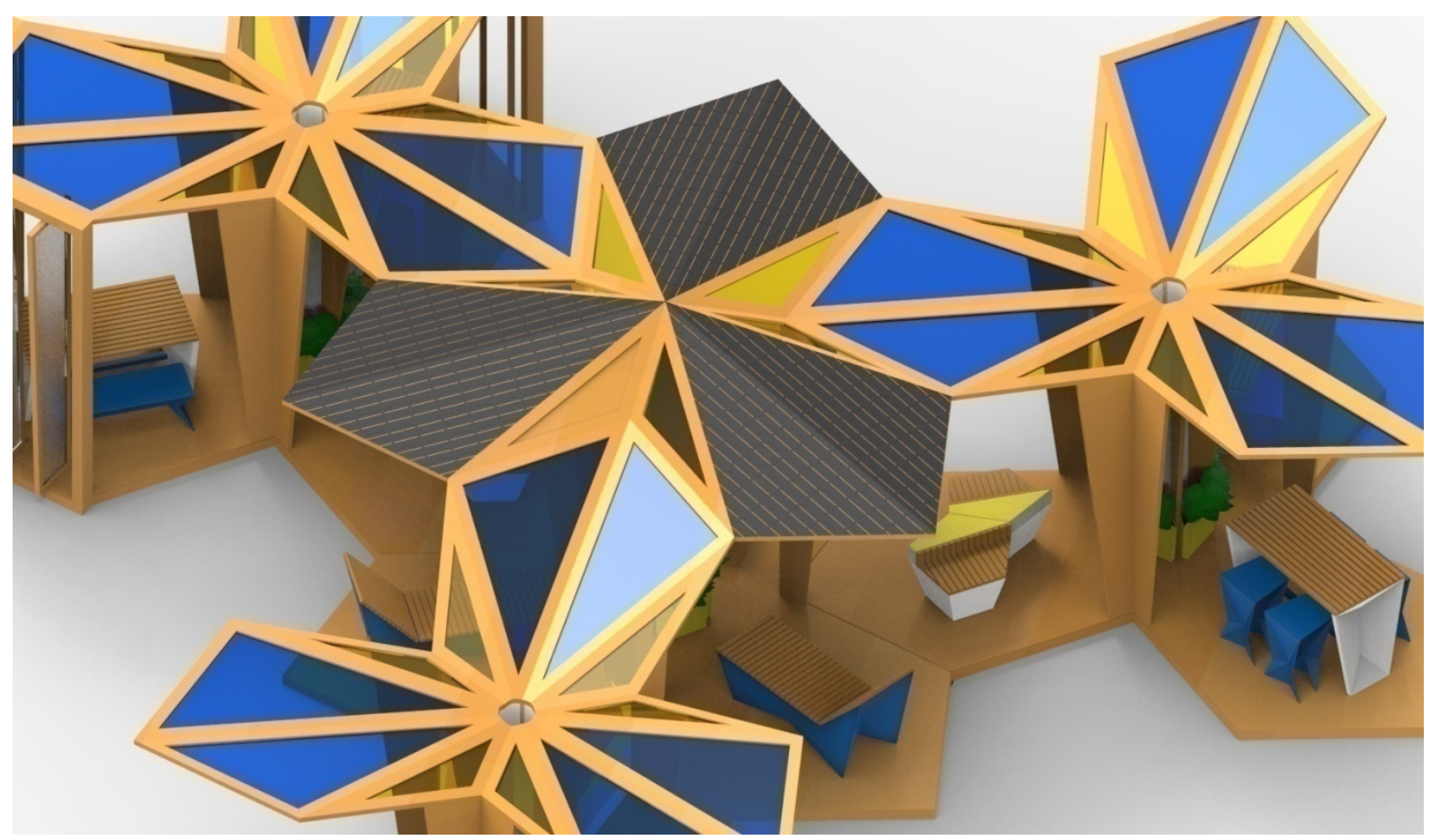

Сл. 9.1-17 Поглед од блиску на соларните панели и цевките за собирање на дождовна вода.

Дизајнирањето на динамични, ротирачки панели на овој павиљон беше направено со цел да се овозможат оптимални услови за употреба на просторот во секакви временски услови. Поради тоа што павиљонот пред се има намена да го подобрува расположението, луѓето во него мора да се чувствуваат удбно. Динамичните панели се со можност за адаптирање, односно, бидејќи страните на аглестиот павиљон се со иста должина, овие панели може да се додадат на сите страни или пак, само на страните каде сончевото зрачење е најсилно и каде е потребна најголема заштита од топлина и отсјај. Панелите со својот дизајн се комплементарни на изгледот на павиљонот, тие имаат трапезни форми чии агли го следат динамичниот дизајн на останатите елементи. Панелите се поставени по сет од 3 на секоја страна и се со можност за ротација од $360^{\circ}$ околу своите оски. Во зависност од осветленоста и ветерот тие форми може да го менуваат својот агол - кога сонцето е 
премногу силно, да се затворат под агол од $0^{\circ}$, кога сончевото зрачење е послабо да бидат максимално отворени, а во сите други ситуации, елементите може да се постават под агол на наклон во зависност од надворешните влијанија и интензитетот на сончеви зраци, слично како и листовите на растенијата во природата. Самите панели се предвидени како дрвени рамки во кој е сместен полу-транспарентен материјал со матирана, млечна боја, со цел да дозволуваат продор на природна светлина и во случај кога би биле поставени скоро на сите страни од павиљонот и во затворена положба. Ваквата изведба овозможува добра заштита од ветер и сонце без да ја попречи функционалноста во ентериерот.
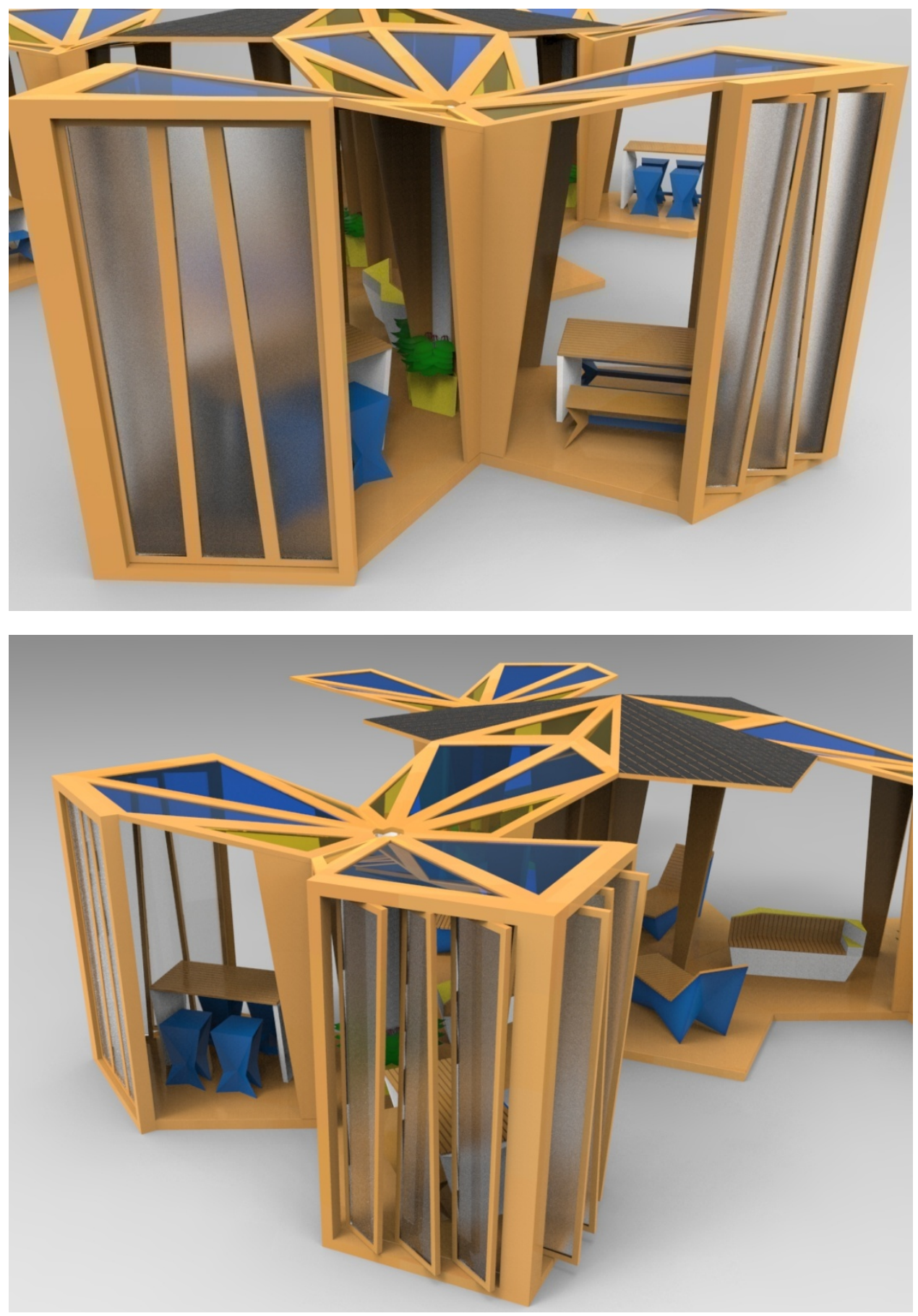

Сл. 9.1-18,19 Поглед од блиску на ротирачките панели за заштита од сонце и ветер. 
Со цел зголемување на врската со природата при престој во павиљонот, освен тоа што околу него се предвидени бројни хортикултурни единици, растенијата се вклучени и во самата внатрешност. Кај центраните столбови на секој модул е предвиден простор за додавање на растенија и цвеќиња кои ќе го зголемуваат позитивното чувство и чувството на релаксација кај корисниците кога тие престојуваат внатре за време на пауза или за да работат, а ова е особено важно во зимските денови кога надвор нема вегетација. Таа врска со природата е засилена и преку „транспарентноста“ на самиот павиљон - тој е отворен кон паркот во кој се наоѓa и растенијата околу него; има максимална употреба на дневна светлина (како контраст на затворените канцеларии со вештачко осветлување кое креира чувство на дополнителен замор); ротирачките панели се полу-транспарентни и овозможуваат доволен продор на светлина и во случај кога се затворени; и има триаголни сегменти на кровот кои се изработени од транспарентен материјал и имаат функција на сончев кров кој отвора поглед кон небесниот свод.

Внатрешниот „урбан мебел“ исто така е дизајниран со намена. Секое катче од павиљонот е дизајнирано наменски со цел да ги задоволи принципите на позитивен дизајн, т.е. да има можност за релаксација, за приватност и за социјализирање.

Во централниот дел се поставени клупи во форма на лежаи за релаксација на кои индивидуите може да седнат или да легнат за да се одмараат, да читаат, да размислуваат и сл. Чувството на релаксација е зголемено бидејќи кровот на настрешниците е составен од вградени транспарентни сегменти кои остваруваат интересна игра на светлина и сенка поради тоа што се во боја, и овозможуваат поглед кон небото додека луѓето лежат на клупите.
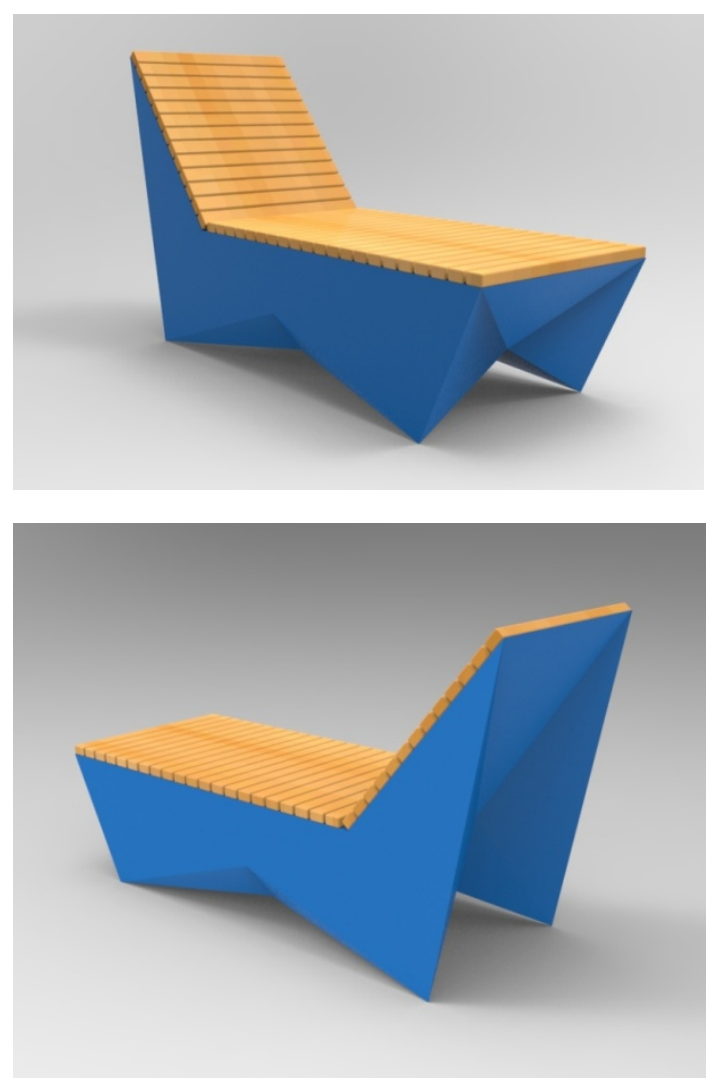

Сл. 9.1-20,21 Клупа во форма на лежај за релаксација. 
На останатиот дел од краците се разиграни неколку различни комбинации на клупи.

Дел од клупите се дизајнирани како клупи за одмор за двајца, со простор на потпирачите кој има функција на масичка за оставање на чашки, книги или ташни.

Другиот дел, пак, од клупите се слични на претходните, но дизајнирани како индивидуални сепариња со мала масичка кои може да ги користи едно лице и на тој начин да му биде овозможена потребната приватност. Но, истите имаат облик кој дозволува да се спојуваат едни со други за да оформат поголеми клупи, за 2 или повеќе лица и да ја остварат можноста за социјализирање. Овие клупи се идеални за употреба при пауза за кафе или ручек каде луѓето може да се релаксираат сами или во друштво.

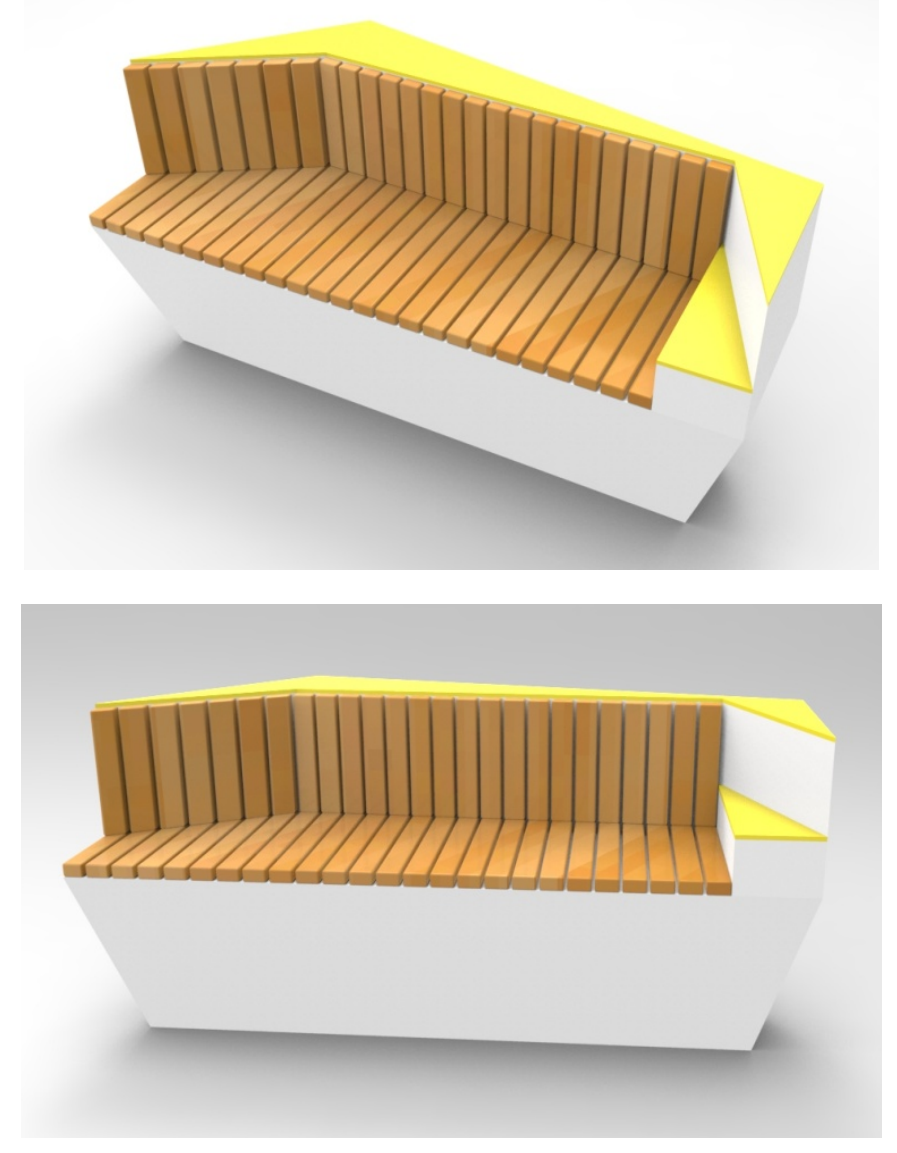

Сл. 9.1-22,23 Клупа за двајца со мали масички. 

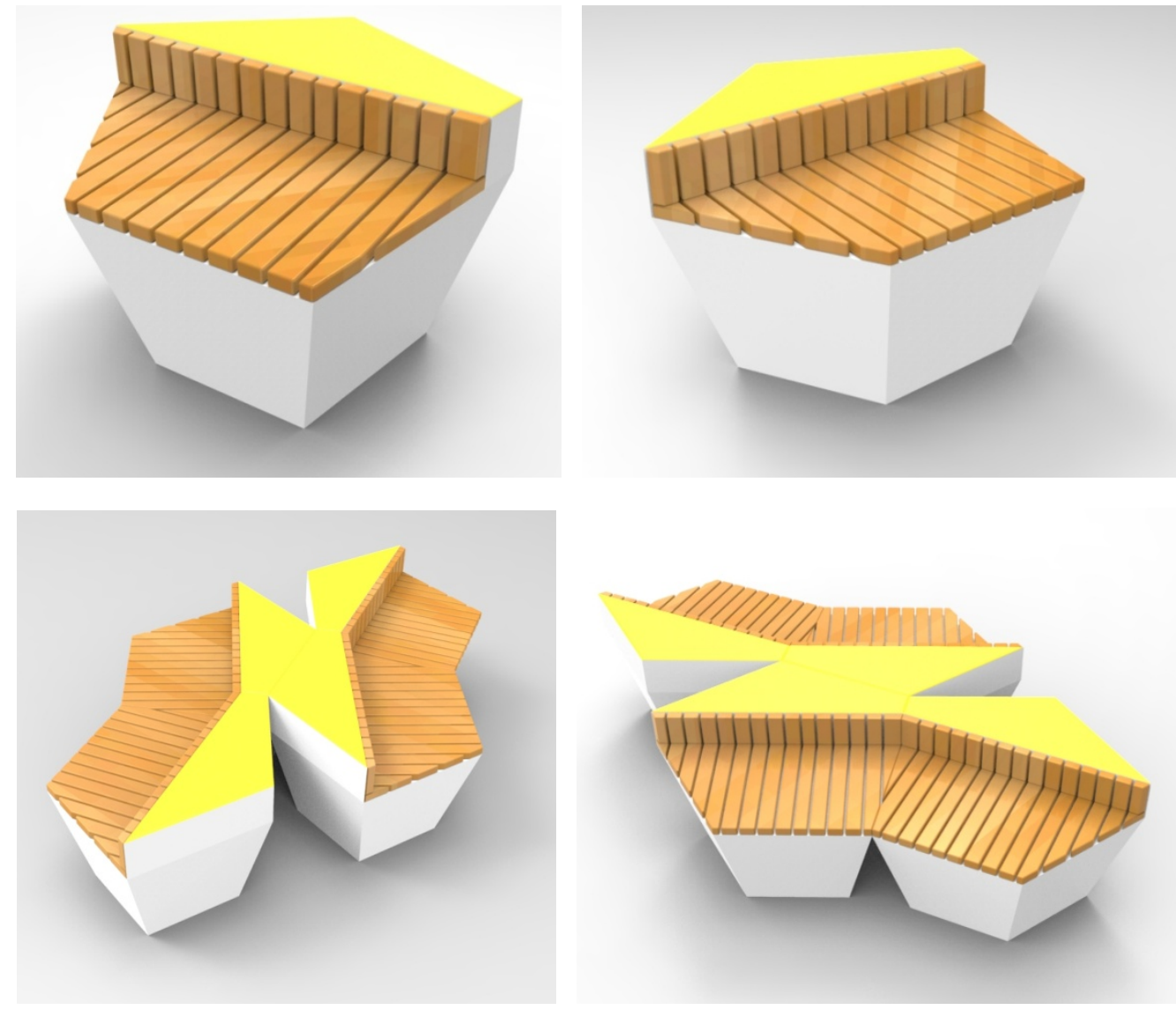

Сл. 9.1-24,25,26,27 Единечни клупи со опција за модуларност и надоврзување едни со други.

Останатиот простор е опремен со маси и клупи, наменети за повеќе луѓе, кои може да се употребуваат како зони за ручек или пак, за состаноци, групни работилници, брејнсторминг сесии итн.

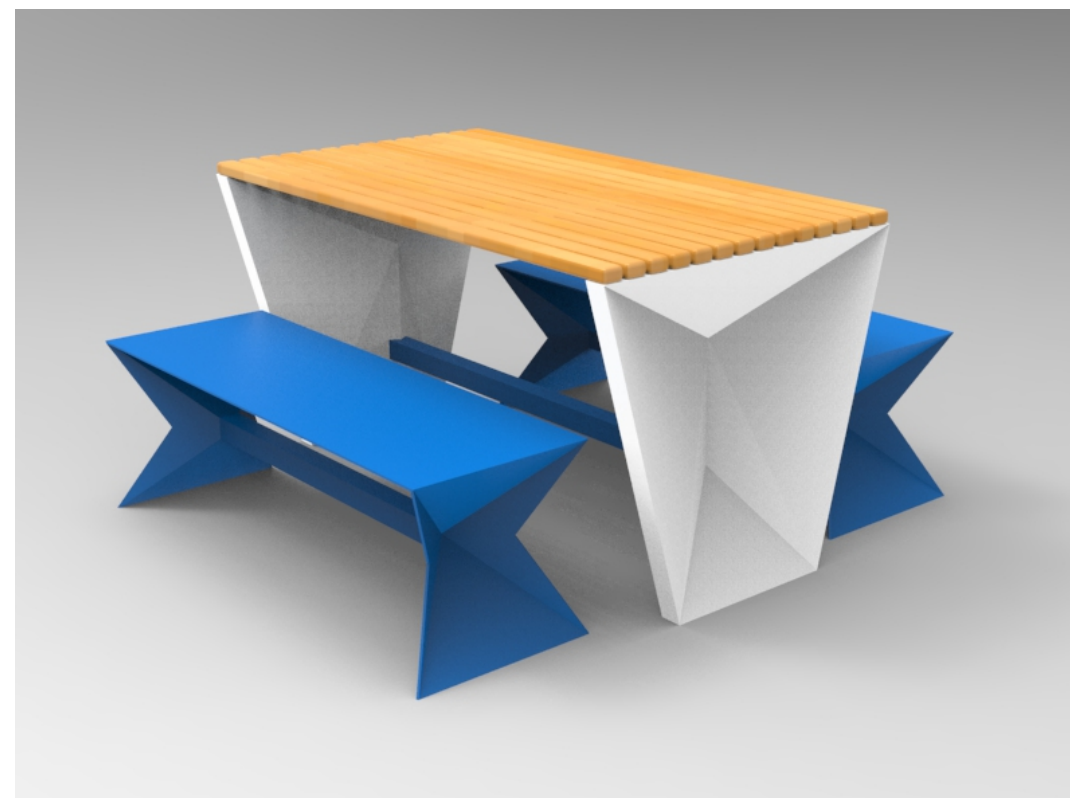




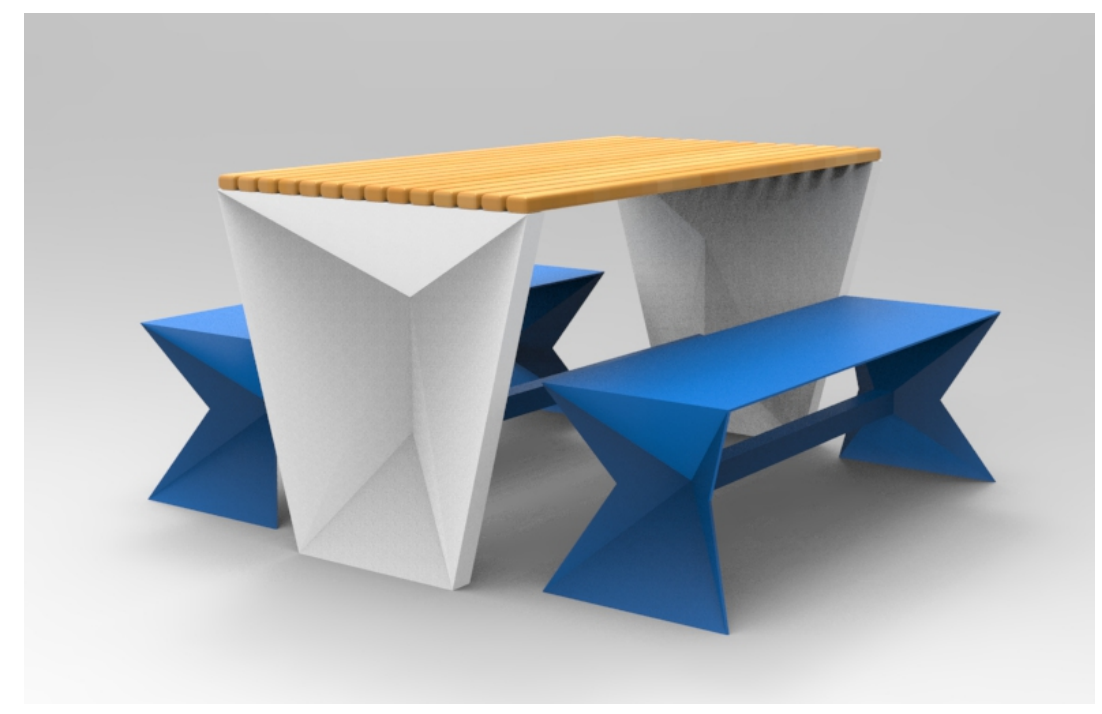

Сл. 9.1-28,29 Маса со клупи за 4 луѓе.

Слични на претходниот вид елементи се високите работни маси со приклучоци за електрични уреди и високи индивидуални столчиња. Овие парчиња мебел се наменети да ја задоволат потребата за индивидуална или групна работа, тие се простор каде луѓето може да ги вршат работните задачи во мирна и пријатна средина каде ќе се чувствуваат релаксирано и креативно.
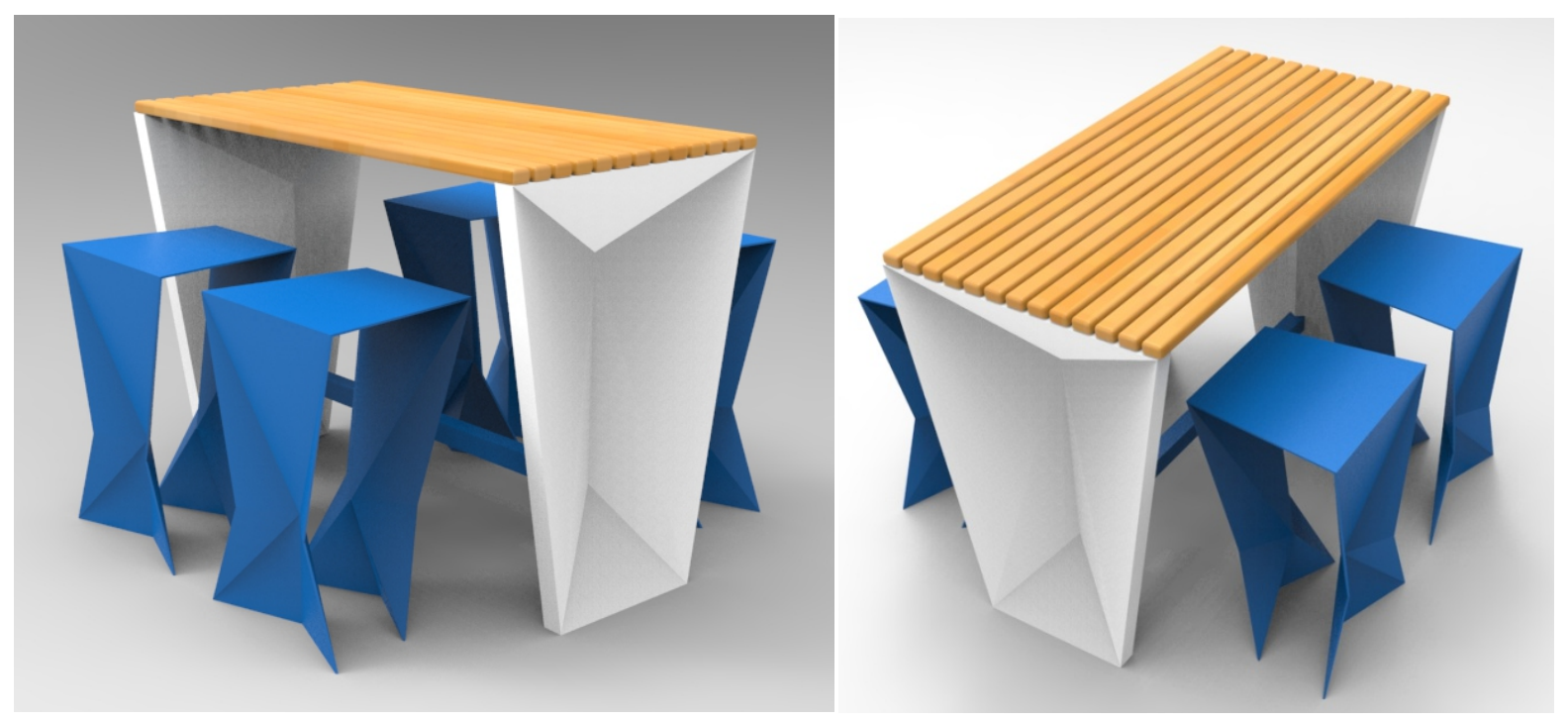

Сл. 9.1-30,31 Висока работна маса со 4 клуб столчиња. 


\section{2 МАТЕРИЈАЛИ И КОНСТРУКЦИЈА}

Како што беше претходно дефинирано преку QFD дијаграмот, главниот материјал применет во конструкцијата на овој павиљон и сите елементи во него (клупи, маси) со кои луѓето стапуваат во директен контакт е дрво. Дрвото е природен, обновлив материјал кој може да се рециклира и чија боја и текстура даваат пријатно чувство на топлина. Токму поради оваа карактеристика на будење позитивни чувства, конструкцијата и внатрешноста на павиљонот се со дрвени елементи и дрвен под. Дополнителни позитивни аспекти од примената на дрво се: мала волуменска маса (околу 13 пати полесно од челикот и 4 пати полесно од бетонот), релативно голема јакост паралелно со влакната, лесна обработка независна од временските услови, големи можности за обликување на напречниот пресек и изгледот на конструктивните елементи, мала осетливост на температурни промени и секако, природна убавина.
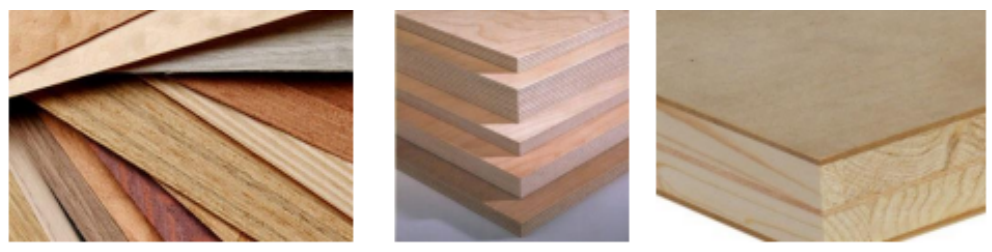

Сл. 9.2-1 Изглед на дрво за конструкција.

Потребната носивост е постигната преку дрвени столбови во централниот дел и на внатрешните агли на секој модул. Столбовите се коси, потесни во долниот дел со цел да се растерети внатрешниот простор и да не се попречи слободната циркулација, а пошироки во горниот дел, во зоната на контакт со кровот за да се постигне потребната цврстина и стабилност.
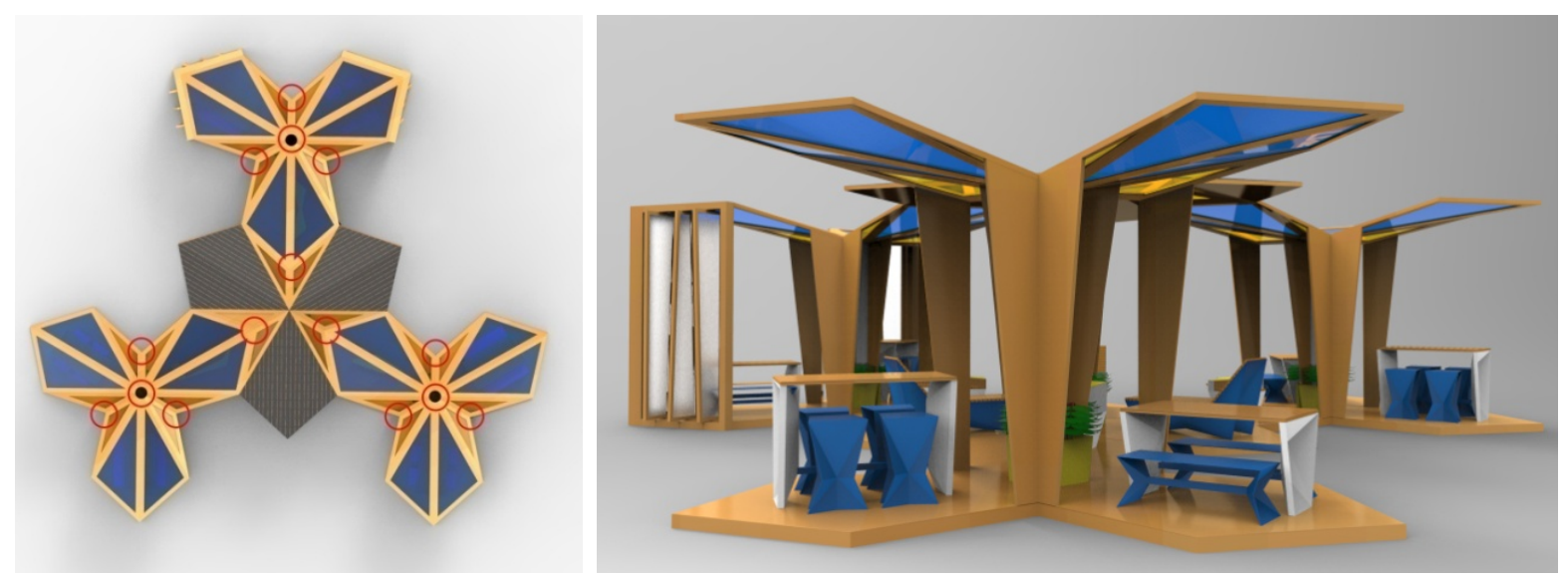

Сл. 9.2-2,3 Точки на поставување на носечките дрвени столбови и нивен изглед.

Кровните сегменти на павиљонот кои се транспарентни се изработени од поликарбонат (РС). Поликарбонатот спаѓa во групата на термопластики, односно полимери кои може да се омекнуваат над одредена температура и да се вратат во нивната првобитна состојба откако ќе се оладат без значителна промена на својствата. Од тука произлегува и нивното својство за рециклирање. Поликарбонатот е применет кај овој павиљон не само поради неговиот изглед на стакло, туку и поради неговите карактеристики на одлична провидност, цврстина, отпорност на температури, отпорност на надворешни услови, отпорност на удари и огноотпорност. 
Поликарбонатните панели постојат во различни бои и степени на провидност што овозможува дополнителна опција за персонализирање на изгледот на павиљонот. Бидејќ поликарбонатните панели се полесни од стакло нема да ја оптоваруваат конструкцијата кога ќе се постават на кровот, а нивната издржливост која е 200 пати поголема од онаа на стаклото ги прави одлични за примена кај надворешни објекти како овој павиљон. Единствената негативна карактеристика кај нив е тоа што деградираат со текот на времето. Нивното деградирање се мери со индекс на пожолтување кој како се зголемува така ја намалува особината на материјалот да пропушта светлина. Поради ова својство животниот век на поликарбонатните панели е околу 10 години, но со додавање на соодветни површински заштити тој би можел да се продолжи и до 20.
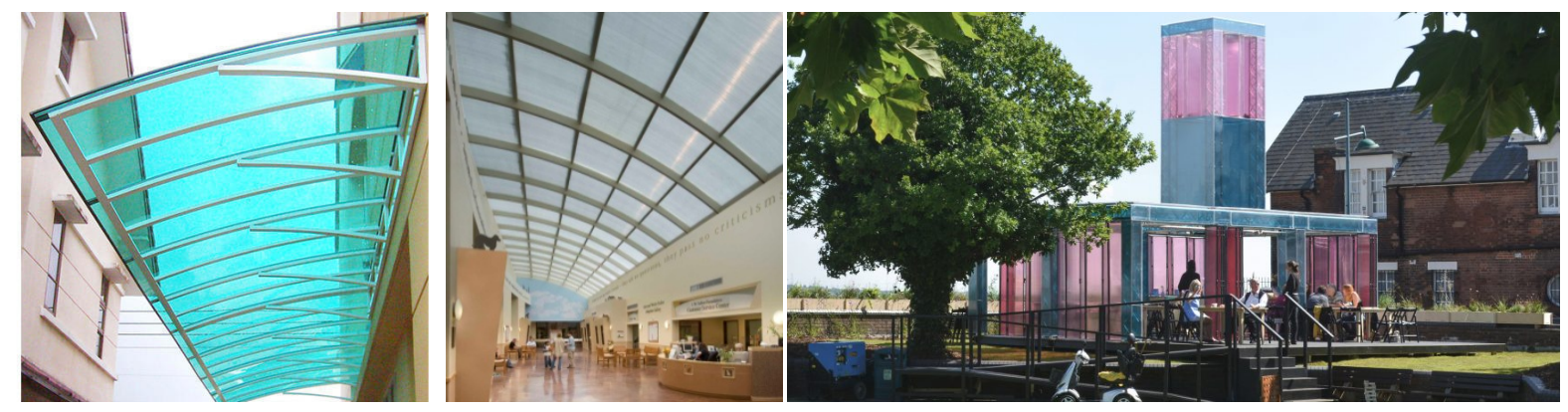

Сл. 9.2-4,5,6 Примери за примена на поликарбонат во дизајнот и архитектурата.

Во однос на динамичните панели на страните на павиљонот, применетиот материјал во дрвените трапезни рамки е акрилно стакло (РМMA), поради неговата сличност со вистинско стакло и можноста да се изработи во вид на мат, полу-провидни плочи кои се отпорни на атмосферски влијанија и сончева светлина.
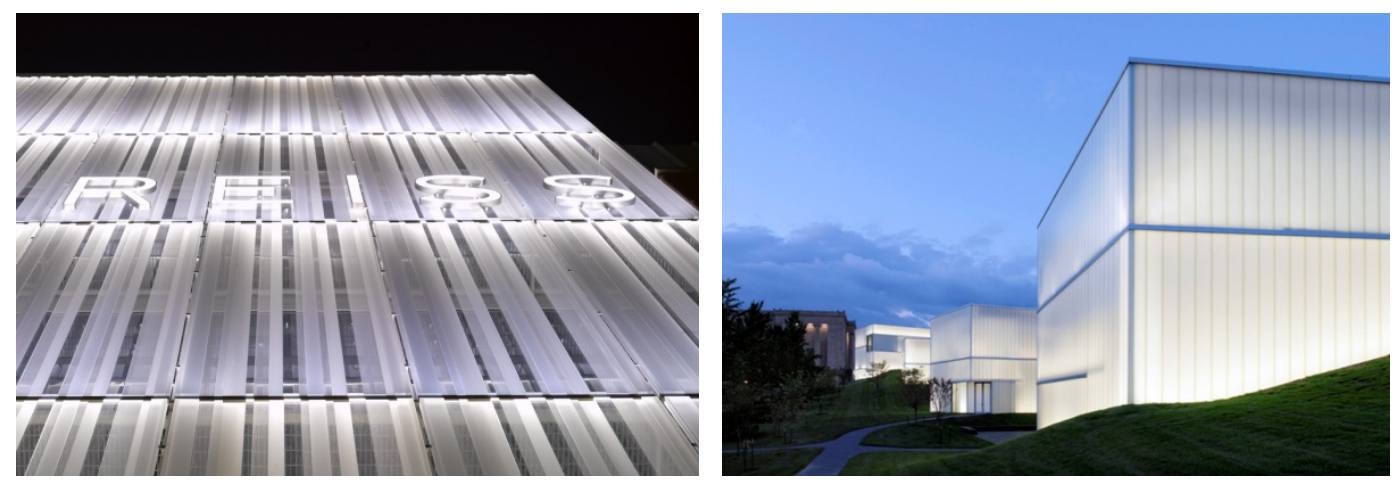

Сл. 9.2-7,8 Примери за примена на акрилно стакло во дизајнот и архитектурата.

Клупите и масите во ентериерот се изработени комбинација на дрвени плочи исечени во вид на штици, од дрво кое би било по избор на инвеститорот во зависност од ефектот кој сака да го постигне и од средствата со кои располага, кои се прицврстени за пластични елементи преку цврсти спојки со навртки. Пластиката употребена за мебелот во ентериерот на павиљонот е полипропилен (РP). Полипропиленот е популарна пластика во дизајнот поради бројните позитивни својства кои ги поседува меѓу кои се: нетоксичност, мала тежина, лесно миење и оддржување, отпорност на топлина (точка на топење $160^{\circ} \mathrm{C}$ ), отпорност на влага, отпорност на хемикалии, физичка издржливост, различни бои итн. 

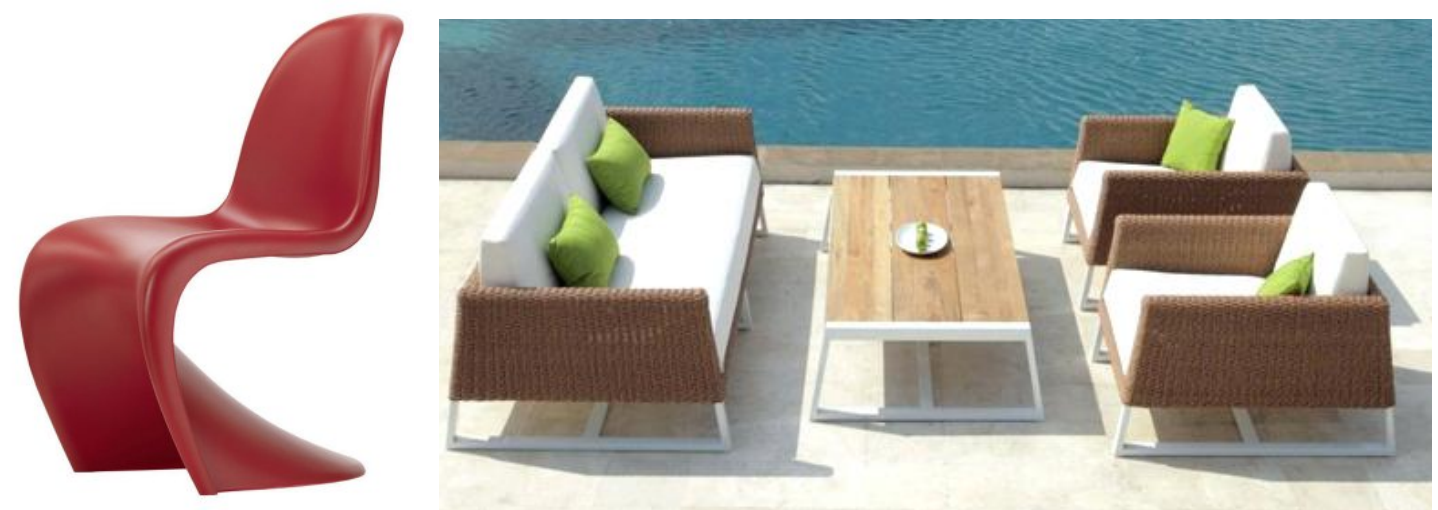

Сл. 9.2-9,10 Примери за примена на полипропилен во дизајнот.

\section{3 ПРИМЕНЕТА ЕРГОНОМИЈА}

Со цел да се постигне максимална удобност и безбедна употреба на павиљонот целиот простор и елементите во него беа дизајнирани следејќи антропометриски мерки од 5-ти и 95-ти перцентил, соодветно на потребата. Особено внимание беше посветено не само на правилно дизајнирање на клупите и масите туку и на зоните на циркулација околу нив поради тоа што претесен простор би имал спротивен ефект и би креирал чувство на нервоза и незадоволство, додека преголем простор би го нарушил чувството на топлина и безбедност. Применетите мерки се прикажани на сликите подолу. [31]

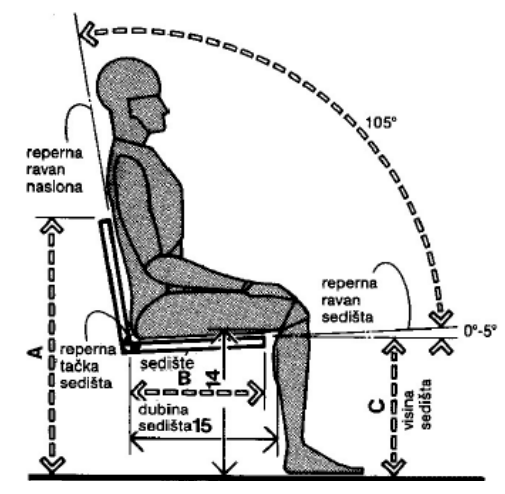

\begin{tabular}{|ccc|}
\hline & in & cm \\
\hline $\mathbf{A}$ & $31-33$ & $78.7-83.8$ \\
\hline $\mathbf{B}$ & $15.5-16$ & $39.4-40.6$ \\
\hline $\mathbf{C}$ & $16-17$ & $40.6-43.2$ \\
\hline $\mathbf{D}$ & $17-24$ & $43.2-61.0$ \\
\hline $\mathbf{E}$ & $0-6$ & $0.0-15.2$ \\
\hline $\mathbf{F}$ & $15.5-18$ & $39.4-45.7$ \\
\hline $\mathbf{G}$ & $8-10$ & $20.3-25.4$ \\
\hline $\mathbf{H}$ & 12 & 30.5 \\
\hline $\mathbf{J}$ & $18-20$ & $45.7-50.8$ \\
\hline $\mathbf{J}$ & $24-28$ & $61.0-71.1$ \\
\hline
\end{tabular}

Сл. 9.3-1 Применети мерки за седиштата на клупите 

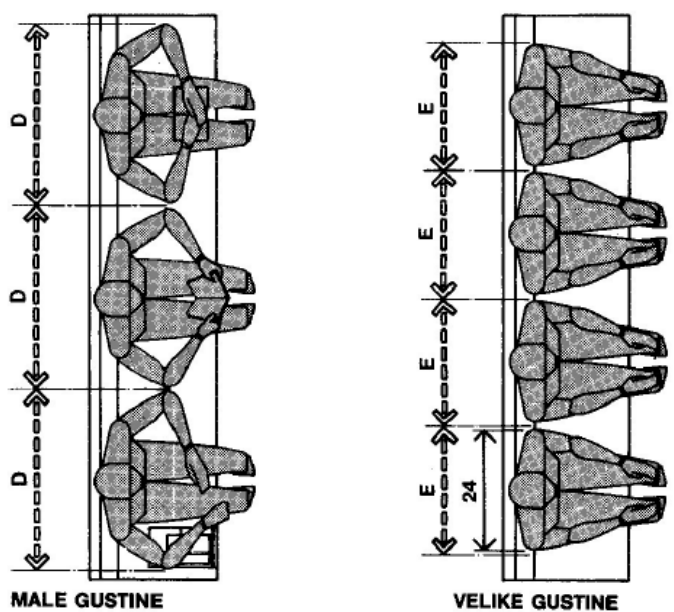

\begin{tabular}{|ccc|}
\hline & in & $\mathrm{cm}$ \\
\hline \hline $\mathbf{A}$ & $18-24$ & $45.7-61.0$ \\
\hline $\mathrm{B}$ & $15.5-16$ & $39.4-40.6$ \\
\hline $\mathrm{C}$ & $16-17$ & $40.6-43.2$ \\
\hline $\mathrm{D}$ & 30 & 76.2 \\
\hline $\mathbf{E}$ & 24 & 61.0 \\
\hline
\end{tabular}

Сл. 9.3-2 Применети мерки за потребниот индивидуален простор кај клупи за повеќе лица

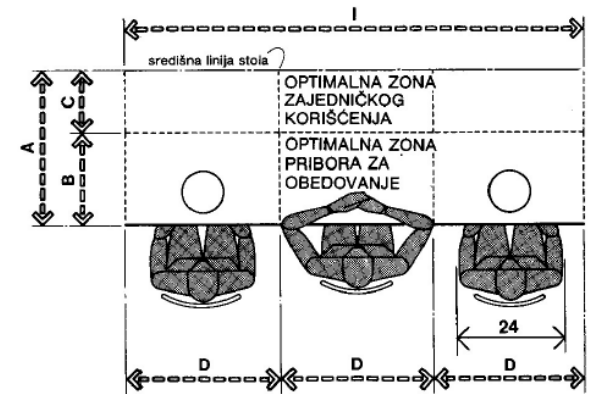

OPTIMALNA ZONA PRIBORA ZA OBEDOVANJE ZA TRI OSOBE

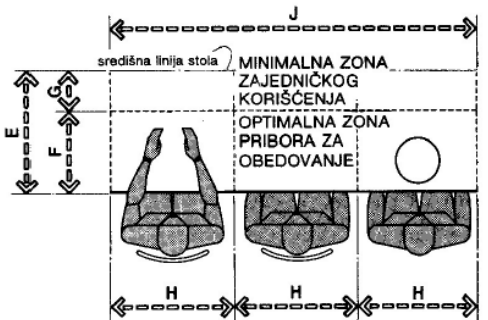

\begin{tabular}{|ccc|}
\hline & in & cm \\
\hline $\mathbf{A}$ & 27 & 68.6 \\
\hline $\mathbf{B}$ & 18 & 45.7 \\
\hline $\mathbf{C}$ & 9 & 22.9 \\
$\mathbf{D}$ & 30 & 76.2 \\
\hline $\mathbf{E}$ & 21 & 53.3 \\
\hline $\mathbf{F}$ & 16 & 40.6 \\
\hline $\mathbf{G}$ & 5 & 12.7 \\
\hline $\mathbf{H}$ & 24 & 61.0 \\
\hline $\mathbf{J}$ & 90 & 228.6 \\
\hline $\mathbf{J}$ & 72 & 182.9 \\
\hline
\end{tabular}

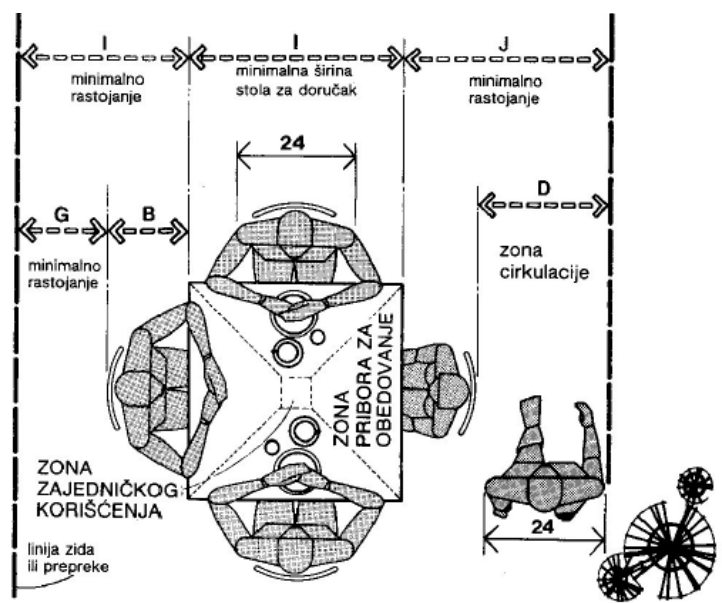

\begin{tabular}{|ccc|}
\hline & in & $\mathrm{cm}$ \\
\hline $\mathbf{A}$ & $96-102$ & $243.8-259.1$ \\
\hline $\mathbf{B}$ & $18-24$ & $45.7-61.0$ \\
\hline $\mathbf{C}$ & 12 & 30.5 \\
\hline $\mathbf{D}$ & 30 & 76.2 \\
\hline $\mathbf{E}$ & $132-144$ & $335.3-365.8$ \\
\hline $\mathbf{F}$ & 96 & 243.8 \\
\hline $\mathbf{G}$ & 18 & 45.7 \\
\hline $\mathbf{H}$ & 54 & 137.2 \\
\hline $\mathbf{5}$ & $36-42$ & $91.4-106.7$ \\
\hline $\mathbf{J}$ & $48 \mathrm{~min}$. & $121.9 \mathrm{~min}$. \\
\hline $\mathbf{K}$ & $18 \mathrm{~min}$. & $\mathbf{4 5 . 7} \mathrm{min}$. \\
\hline
\end{tabular}

Сл. 9.3-3,4 Применети мерки за потребниот индивидуален и заеднички простор при употреба на масите за јадење и работа, како и потребниот простор околу нив 


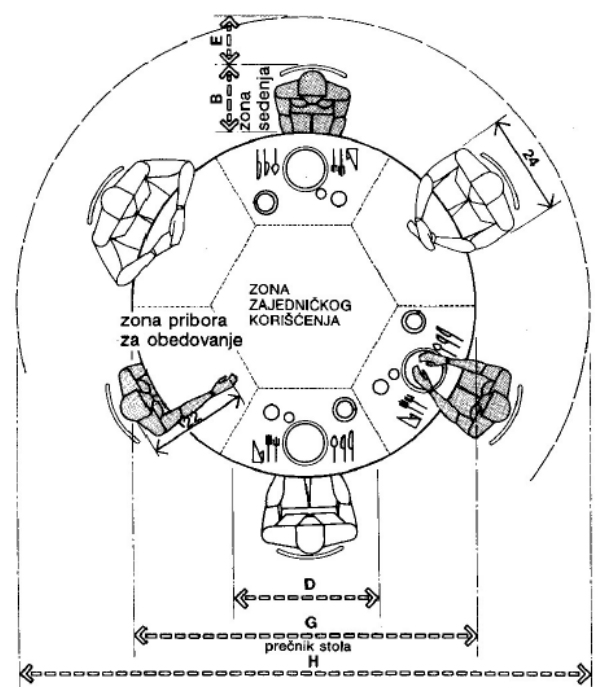

\begin{tabular}{|ccc|}
\hline & in & cm \\
\hline $\mathbf{A}$ & $96-108$ & $243.8-274.3$ \\
\hline $\mathbf{B}$ & $18-24$ & $45.7-61.0$ \\
\hline $\mathbf{C}$ & 60 & 152.4 \\
\hline $\mathbf{D}$ & 30 & 76.2 \\
\hline $\mathbf{E}$ & 12 & 30.5 \\
\hline $\mathbf{F}$ & $30-36$ & $76.2-91.4$ \\
\hline $\mathbf{G}$ & 72 & 182.9 \\
\hline $\mathbf{H}$ & $132-144$ & $335.3-365.8$ \\
\hline
\end{tabular}

Сл. 9.3-5 Применети мерки за маси за повеќе луѓе и потребен простор за седење

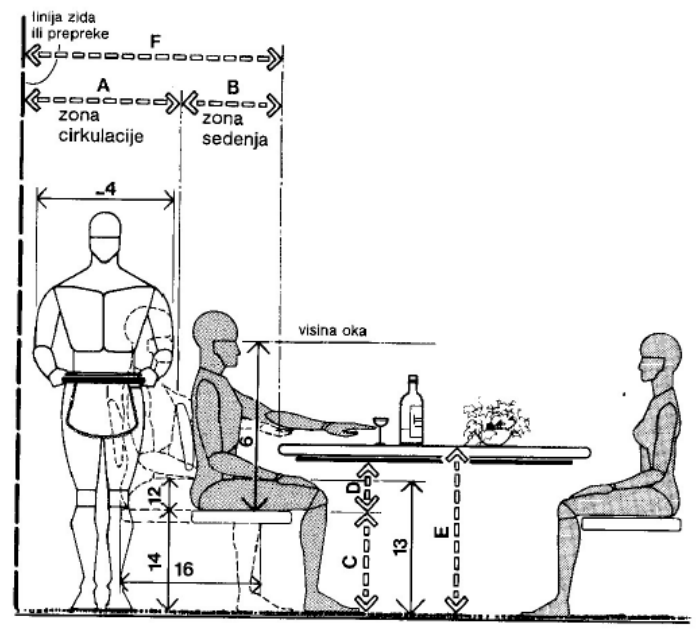

\begin{tabular}{|ccc|}
\hline & in & $\mathrm{cm}$ \\
\hline $\mathbf{A}$ & $30-36$ & $76.2-91.4$ \\
\hline $\mathbf{B}$ & $18-24$ & $45.7-61.0$ \\
\hline $\mathbf{C}$ & $16-17$ & $40.6-43.2$ \\
\hline $\mathbf{D}$ & $7.5 \mathrm{~min}$. & $19.1 \mathrm{~min}$. \\
\hline $\mathbf{E}$ & $29-30$ & $73.7-76.2$ \\
\hline $\mathbf{F}$ & $48-60$ & $121.9-152.4$ \\
\hline
\end{tabular}

Сл. 9.3-6 Применети мерки за висина на маси и столчиња и простор околу нив

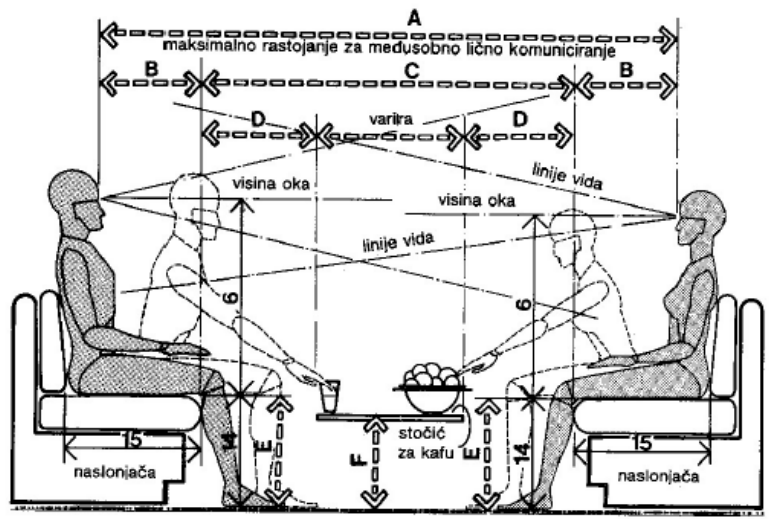

\begin{tabular}{|c|c|c|}
\hline & in & $\mathrm{cm}$ \\
\hline A & $84-112$ & $213.4-284.5$ \\
\hline $\mathbf{B}$ & $13-16$ & $33.0-40.6$ \\
\hline C & $58-80$ & $147.3-203.2$ \\
\hline D & $16-18$ & $40.6-45.7$ \\
\hline E & 14-17 & $35.6-43.2$ \\
\hline$F$ & $12-18$ & $30.5-45.7$ \\
\hline $\mathbf{G}$ & $30-36$ & $76.2-91.4$ \\
\hline $\mathbf{H}$ & $12-16$ & $30.5-40.6$ \\
\hline & $60-68$ & $152.4-172.7$ \\
\hline J & $54-62$ & $137.2-157.5$ \\
\hline
\end{tabular}

Сл. 9.3-7 Применети мерки за ниски масички и столчиња 


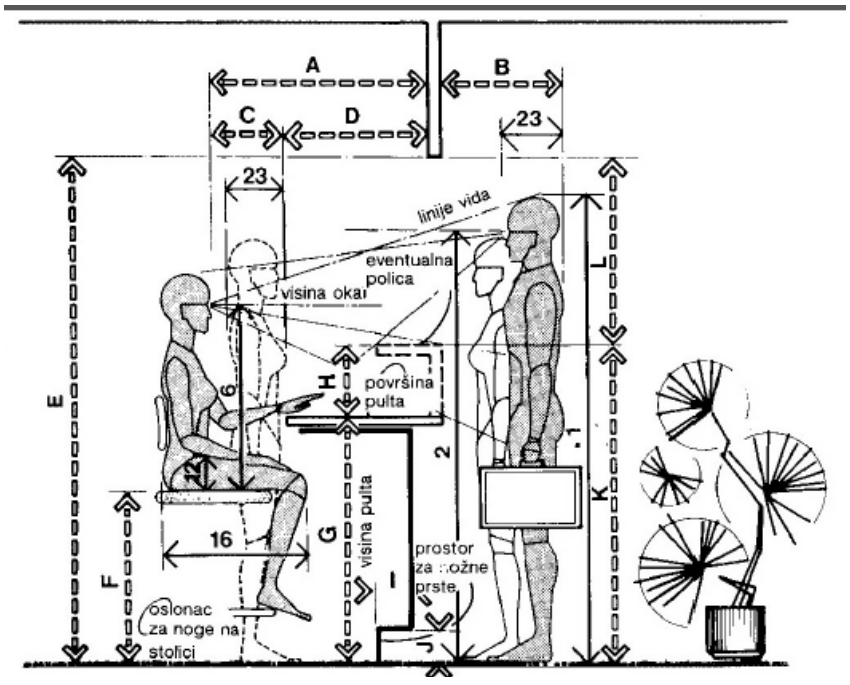

\begin{tabular}{|ccc|}
\hline & in & $\mathrm{cm}$ \\
\hline $\mathbf{A}$ & $40-48$ & $101.6-121.9$ \\
\hline $\mathbf{B}$ & $24 \mathrm{~min}$. & $61.0 \mathrm{~min}$. \\
\hline $\mathbf{C}$ & 18 & 45.7 \\
\hline $\mathbf{D}$ & $22-30$ & $55.9-76.2$ \\
\hline $\mathbf{E}$ & $78 \mathrm{~min}$. & $198.1 \mathrm{~min}$. \\
\hline $\mathbf{G}$ & $24-27$ & $61.0-68.6$ \\
\hline $\mathbf{H}$ & $36-39$ & $91.4-99.1$ \\
\hline $\mathbf{I}$ & $8-9$ & $20.3-22.9$ \\
\hline $\mathbf{J}$ & $2-4$ & $5.1-10.2$ \\
\hline $\mathbf{K}$ & $44-48$ & $111.8-121.9$ \\
\hline $\mathbf{L}$ & $34 \mathrm{~min}$. & $86.4 \mathrm{~min}$. \\
\hline $\mathbf{M}$ & $44-48$ & $111.8-121.9$ \\
\hline $\mathbf{N}$ & 54 & 137.2 \\
\hline $\mathbf{O}$ & $26-30$ & $66.0-76.2$ \\
\hline $\mathbf{P}$ & 24 & 61.0 \\
\hline $\mathbf{Q}$ & 30 & 76.2 \\
\hline $\mathbf{R}$ & $15-18$ & $38.1-45.7$ \\
\hline $\mathbf{S}$ & $29-30$ & $73.7-76.2$ \\
\hline $\mathbf{T}$ & $10-12$ & $25.4-30.5$ \\
\hline $\mathbf{U}$ & $6-9$ & $15.2-22.9$ \\
\hline $\mathbf{V}$ & $39-42$ & $99.1-106.7$ \\
\hline & & \\
\hline
\end{tabular}

Сл. 9.3-8 Применети мерки за високи маси и столчиња
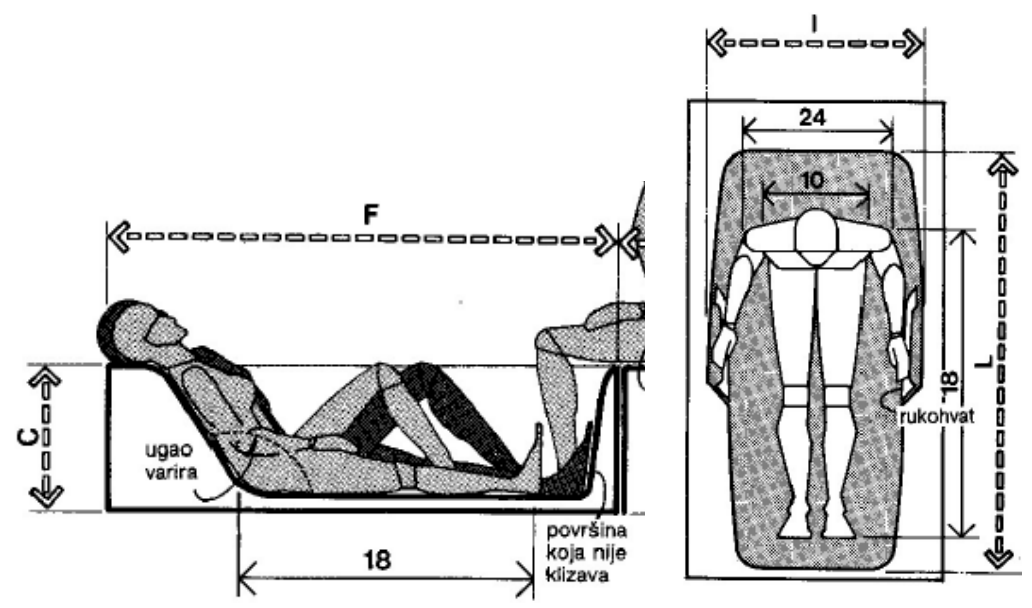

\begin{tabular}{|ccc|}
\hline & in & $\mathrm{cm}$ \\
\hline $\mathbf{A}$ & $18-21$ & $45.7-53.3$ \\
\hline $\mathbf{B}$ & 40 & 101.6 \\
\hline $\mathbf{C}$ & $15-22$ & $38.1-55.9$ \\
\hline $\mathbf{D}$ & $30-34$ & $76.2-86.4$ \\
\hline $\mathbf{E}$ & $40-50$ & $101.6-127.0$ \\
\hline $\mathbf{F}$ & 66 & 167.6 \\
\hline $\mathbf{G}$ & $12 \mathrm{~min}$. & $30.5 \mathrm{~min}$. \\
\hline $\mathbf{H}$ & $18 \mathrm{max}$. & $45.7 \mathrm{max}$. \\
\hline $\mathbf{L}$ & $26-27$ & $66.0-68.6$ \\
\hline $\mathbf{J}$ & $40-44$ & $101.6-111.8$ \\
\hline $\mathbf{K}$ & $66-70$ & $167.6-177.8$ \\
\hline $\mathbf{L}$ & $56-60$ & $142.2-152.4$ \\
\hline
\end{tabular}

Сл. 9.3-9 Применети мерки за клупите за релаксирање 
9.4 ДИМЕНЗИИ НА КОМПОНЕНТИТЕ
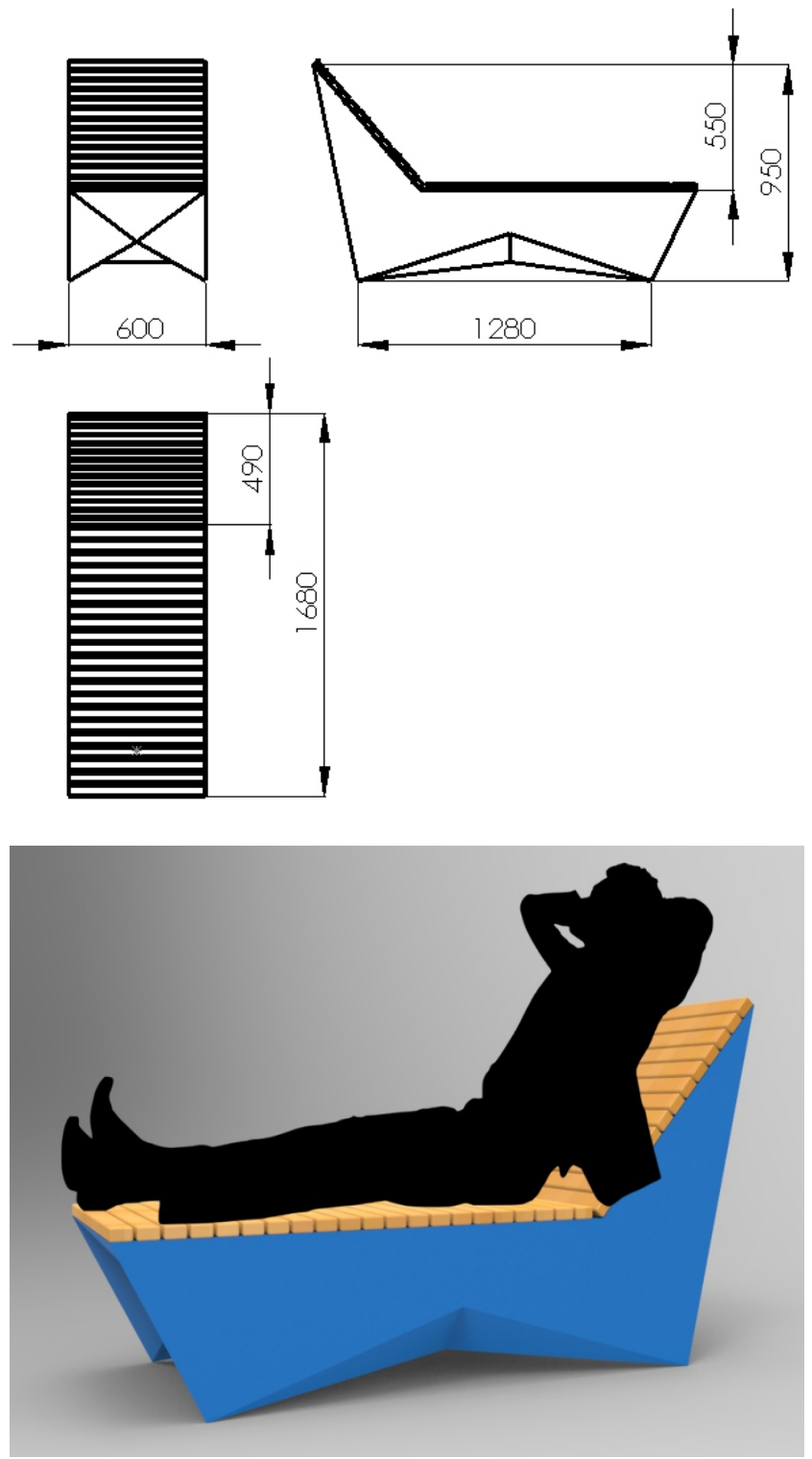

Сл. 9.4-1,2 Димензии на клупа за релаксирање
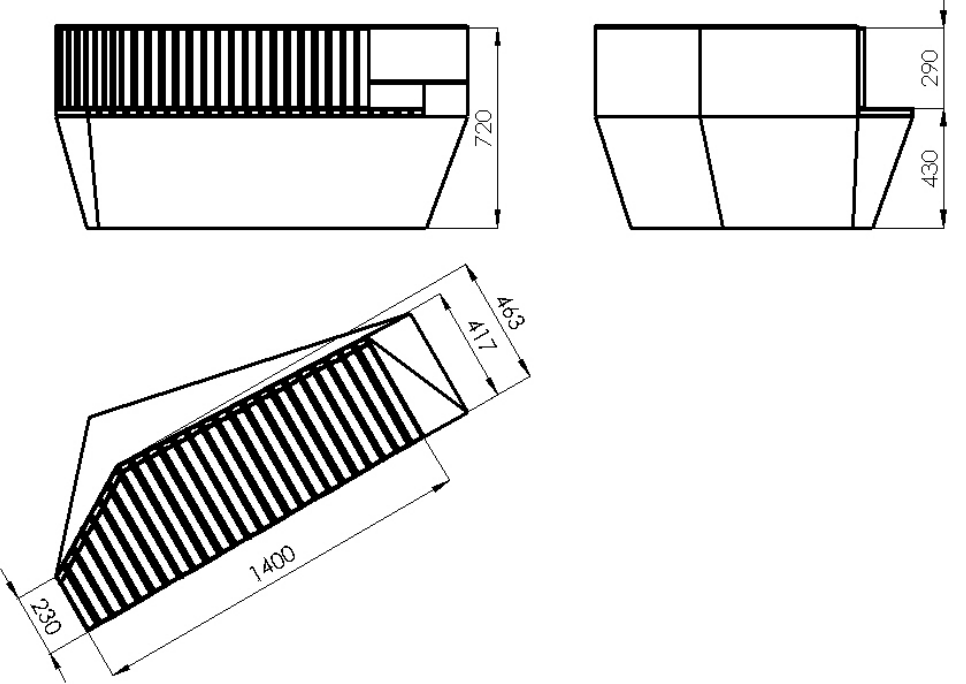


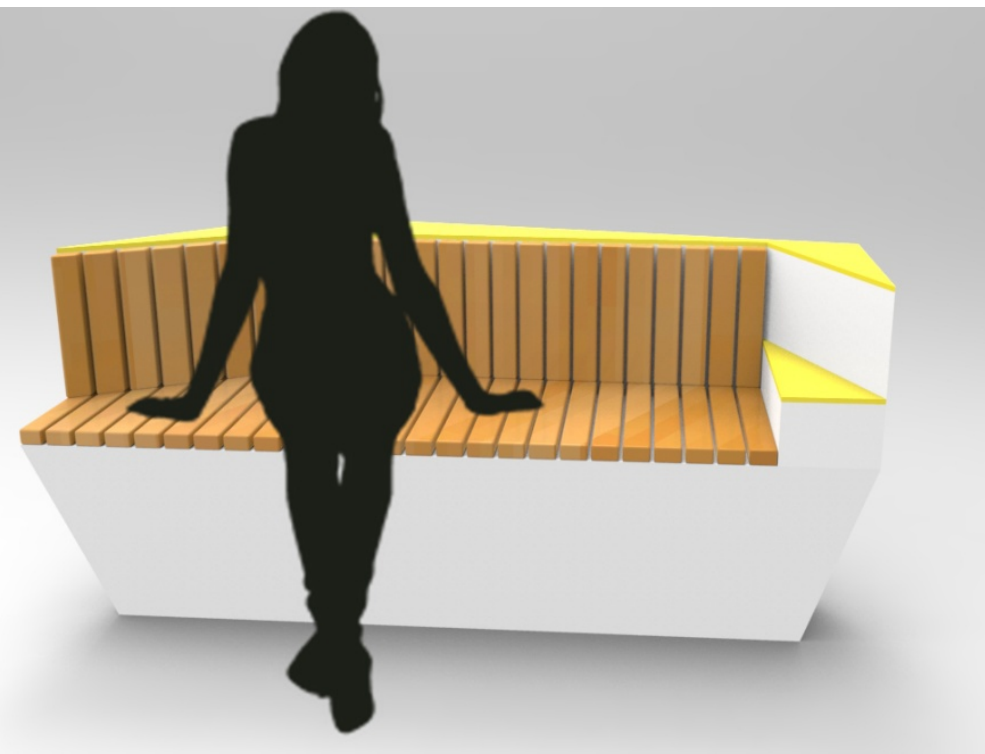

Сл. 9.4-3,4 Димензии на клупа за двајиа
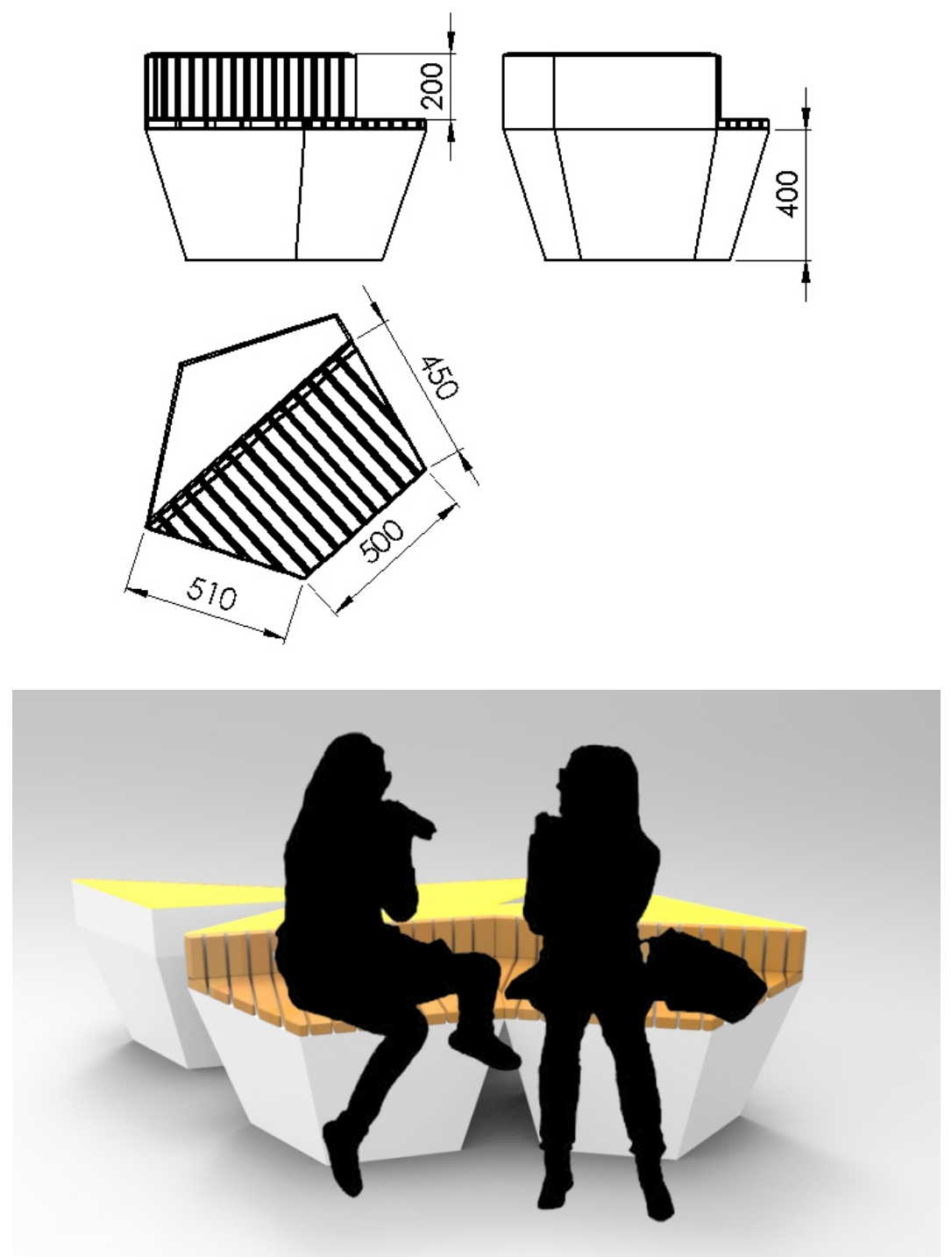

Сл. 9.4-5,6 Димензии на единечни, модуларни клупи 

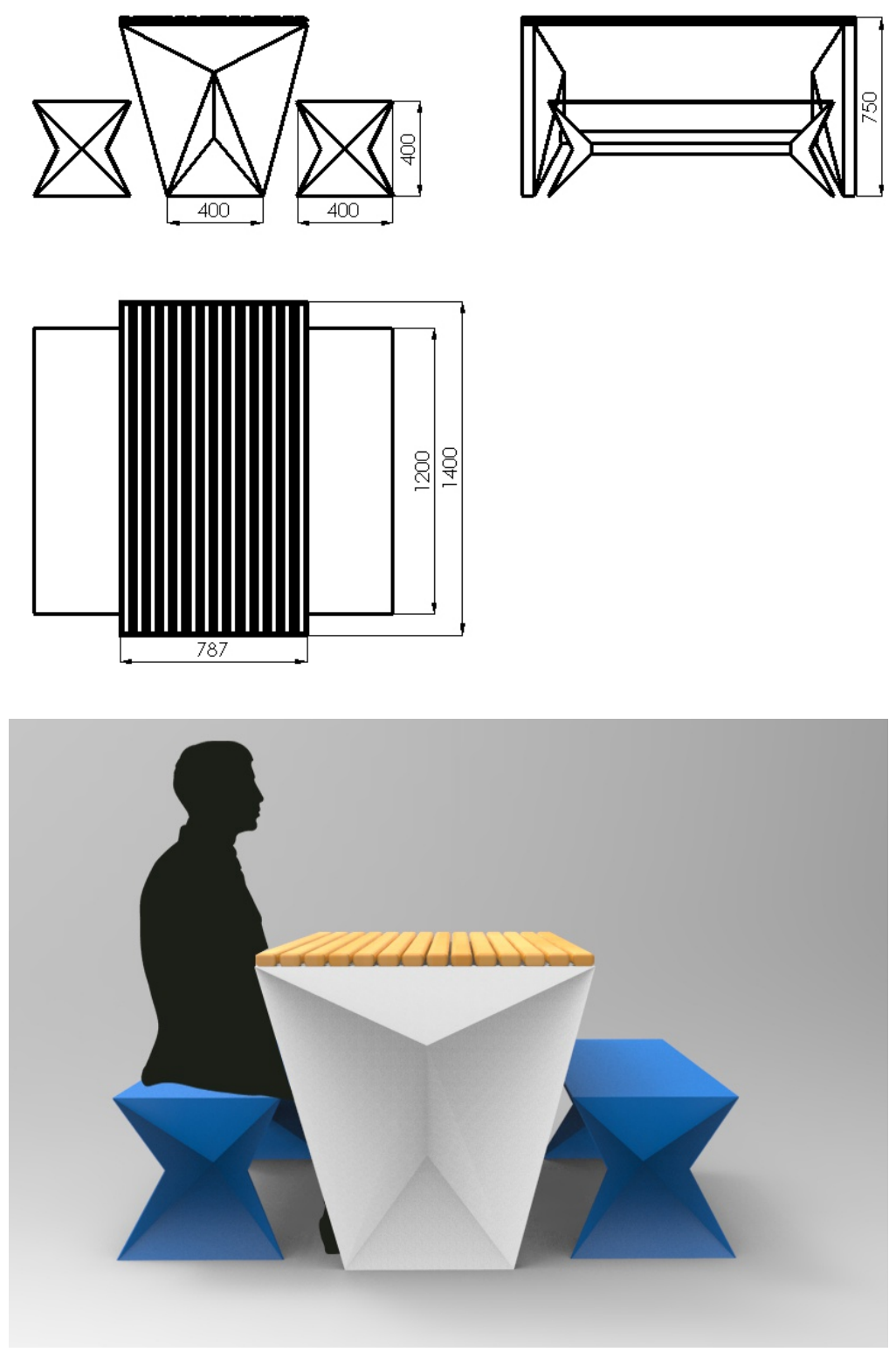

Сл. 9.4-7,8 Димензии на ниски маси со клупи
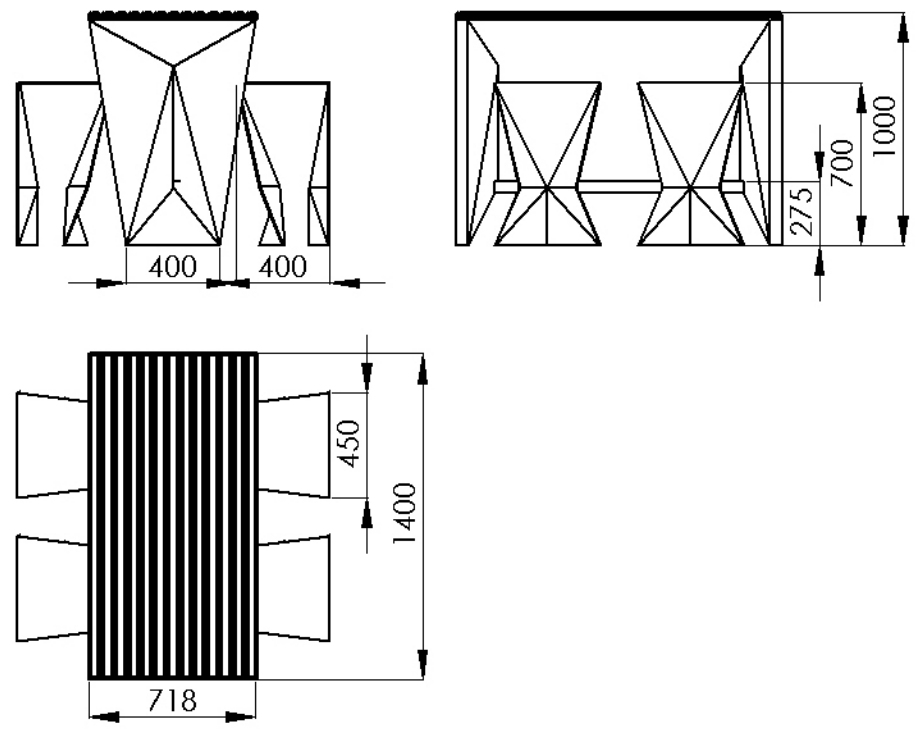


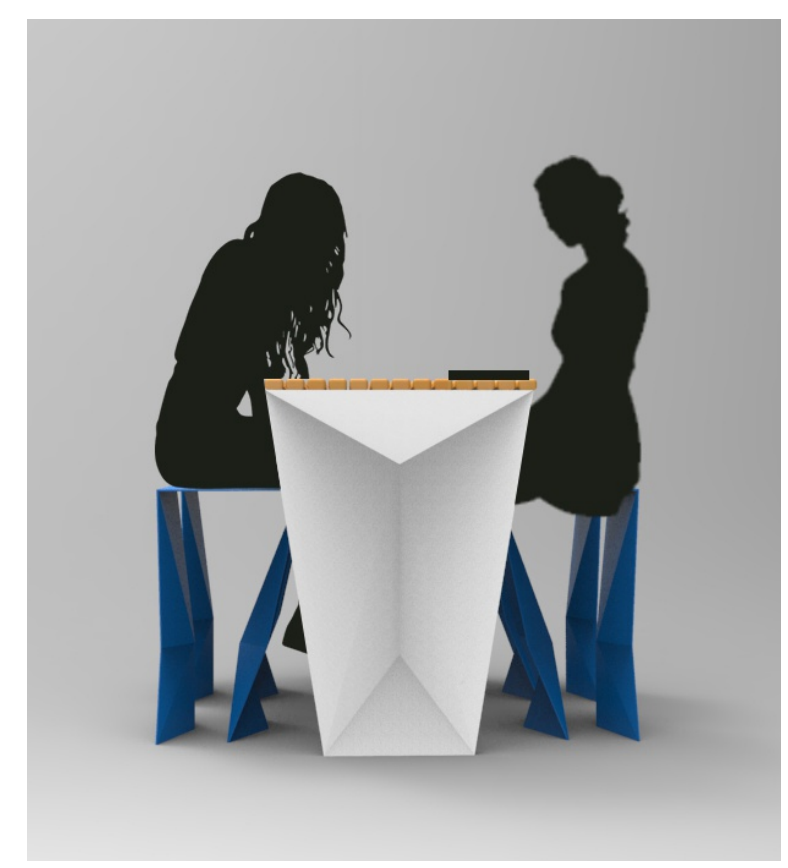

Сл. 9.4-9,10 Димензии на високи маси со барски столчиња

\section{5 ПСИХОЛОГИЈА НА БОИ - ОБРАЗЛОЖУВАЊЕ НА ИЗБОРОТ НА БОИ}

Во овој магистерски труд, чиј главен фокус е истражување на начините преку кои дизајнот може да влијае врз подобрување на расположението и да придонесе за долгорочно добро ментално здравје, истражувањето на влијанието кои го имаат боите беше исклучително важно. Поради тоа, беше дополнително разгледан можниот ефект врз мислите и чувствата на потенцијалните корисници на павиљонот кој би произлегол од различни комбинации на бои аплицирани врз дизајнираниот павиљон.

Боите играат важна улога во нашите животи. Веќе е добро познато дека боите потсвесно влијаат врз начинот на кој луѓето ги перцепираат објектите со кои стапуваат во контакт, како и врз тоа како се чувствуваат и делуваат. Бојата може да игра важна улога во пренесувањето информации, да креира одредени расположенија, па дури и да влијае врз одлуките што луѓето ги прават. Психолошката перспектива на боите е всушност начинот на кој нашата психа и емоции реагираат на нив.

Уште во најраните истражувања, се забележува поврзаноста на различни бои со различни типови на расположение. Карол Лолеранд и Едвард Лолер во нивното истражување објавено под наслов „Color - Mood Associations in Young Children” (1965) направиле едноставно испитување на асоцијацијата на боите со различни расположенија кај мали деца, од 3 до 4 години. Група од 48 деца била поделена во 2 подгрупи. На едната група деца им била раскажана тажна приказна, а на другата група весела приказна, по што, од децата било побарано да изберат една боичка која ги асоцира на раскажаната приказна. Децата кои ја слушнале веселата приказна главно избрале жолта боичка, додека останатите бирале темни боички, најмногу кафена [29].

Април С.Одом и Шанон С.Шолц го објавиле своето истражување „The Reds, Whites, and Blues of Emotion : Examining Color Hue Effects on Mood Tones" (2004) [27] 
кое било спроведено со цел да се утврди дали навистина боите имаат различно влијание врз расположението на луѓето. Резултатите покажале дека примарните бои се главно оние кои се перцепираат како весели, возбудливи и позитивни, за разлика од непримарните бои кои биле перцепирани како смирувачки, особено варијанти на сино-зелена боја. Дополнително, посветлите нијанси на боите предизвикале засилување или намалување на интензитетот на соодветните расположенија, на пример, посветла црвена боја значела намалување на интензитетот на возбуда, а зголемување на чувството на смиреност.

Во друго истражување спроведено од Латориа Н.Нортон, објавено под наслов „What color is your mood“ (2009) [28] исто така е изведен заклучокот дека бојата е силно поврзана со емоциите. Испитувањето било спроведено со 75 студенти на кои им биле покажувани бои по случаен избор на компјутерски екран и им биле поставувани 3 прашања во врска со нивното расположение. Резултатите покажале дека $80 \%$ од позитивните одговори биле врзани за црвени, жолти, сини и виолетови бои. Учесниците се изјасниле дека позитивно реагирале на примарните бои, а за ахроматските нијанси им се појавиле чувства на тага, лутина, депресија, страв, смрт, жалост, и сл. Белата, сепак, добила позитивни реакции бидејќи ги потсетувала на невиност, чистота, надеж, невеста, снег, гулаби и памук.

Други истражувања повеќе се фокусирани на влијанието на различни бои врз перформансите на луѓето при вршење на одредени задачи. Во онлајн изданието на списанието „Science“ (2009) [30], Рави Метха и Руи 3ху го објавиле своето истражување во кое учествувале 600 учесници со цел да се утврди начинот на кој се менува когнитивното однесување откако испитаниците се изложени на црвено или сино влијание. Резултатите покажале дека испитаниците изложени на црвено биле подобри во вршење на задачи поврзани со детали како проверување на граматички грешки или паметење зборови, додека сината група имала подобри резултати на задачите поврзани со креативност и имагинација како креирање на макети од дадени форми и сл. Ова укажува на можноста за употреба на различни типови на бои според посакуваните резултати од луѓето.

Одредени групи истражувачи, пак, во кои соработувале внатрешни дизајнери, архитекти и експерти за бои, биле фокусирани на начинот на кои луѓето реагираат кога се наоѓаат во простор за забава каде доминира црвена, жолта или сина боја. Резултатите покажале дека првично испитаниците го преферирале жолтиот или црвениот простор, но подолго се задржувале во синиот простор. Оние во жолтите и црвени соби биле посоцијални и поактивни, но кај нив се јавило поголемо чувство на жед и глад.

Наведените примери се само дел од бројните истражувања на тема бои и емоции, а од нив е јасно видливо влијанието врз чувствата кои различни бои ги предизвикуваат. Примарните бои се оние кон кои луѓето јавуваат најсилни чувства. Црвената боја потсвесно ја врзуваме со итни случаи, грешки, предупредувања и лесно го насочува нашето внимание кон детали. Наспрема неа, жолтата најчесто ја врзуваме со позитивни мисли и чувства бидејќ не асоцира на топлина, сонце, енергија. Сините и зелените бои кои не потсетуваат на природни елементи го стимулираат нашето креативно размислување и смирение. Белата боја исто така, буди позитивни чувства 
поради асоцијацијата со нежност и чистота. Поради ова, главните бои кои беа избрани при дизајнирањето на овој павиљон се сина, жолта и бела. Овие бои совршено се вклопуваат со топлата, природна текстура на дрвото. Сино-жолтите детали го даваат потребниот контраст и со тоа го прават дизајнот по впечатлив, а истовремено потсетуваат на лето, сонце, море, природа, што во комбинација со растенијата во внатрешноста на павиљонот и околниот парк го будат чувството на врска со природата. Сината боја го дава чувството на смирение и будење на креативноста, а жолтата на сончевина и весели мисли. 


\section{0. ЕВАЛУАЦИЈА НА ДИЗАЈНОТ}

Со цел да се утврди начинот на кој луѓето би реагирале на павиљонот и дали дизајнот ги потврдува зададените хипотези, беше спроведено тестирање во кое беа вклучени 30 испитаници, возрасни, вработени граѓани на Скопје. На нив им беа покажани слики од ЗД модели на павиљонот претставен од различни агли, а од испитаниците беше побарано да заокружат една опција од зададена листа на зборови кои опишуваат различни видови на емоции. Испитаниците требаше да ја заокружат емоцијата која е најизразена кај нив кога ги гледаат визуелизациите од павиљонот. Листата на понудени емоции беше следната:

- лутина

- тага/депримираност/студенило

- безбедност

- иритација/вознемиреност

- смирение

- релаксација

- креативност/имагинација

- забава/возбуда

- среќа/веселост

- умор/поспаност

- здодевност

- неутралност

- љубов

- омраза

Тестирањето е визуелно и едноставно, само со заокружување, без пообемни прашања кои бараат дополнително пишување или објаснување, се со цел испитаниците да не се чувствуваат заморени при одговорањето и да можат да го заокружат она што прво ќе го почувствуваат и помислат.

Ова испитување беше потребно за да се утврди дали павиљонот би влијаел позитивно врз луѓето кои ќе престојуваат во него. Резултатите од истражувањето се прикажани подолу табеларно, а потоа и сликовито преку графикон на кој се претставени најчесто појавените емоции кај испитаниците при гледање на слики од павиљонот. 


\begin{tabular}{|l|l|}
\hline Лутина & 0 \\
\hline Тага/ Депримираност/ Студенило & 0 \\
\hline Безбедност & 4 \\
\hline Иритација/ Вознемиреност & 0 \\
\hline Смирение & 6 \\
\hline Релаксација & 7 \\
\hline Креативност/ Имагинација & 6 \\
\hline Забава/ Возбуда & 0 \\
\hline Среќа/ Веселост & 5 \\
\hline Умор/ Поспаност & 0 \\
\hline Здодевност & 0 \\
\hline Неутралност & 2 \\
\hline Љубов & 0 \\
\hline Омраза & 0 \\
\hline
\end{tabular}

Таб. 10-1 Табеларен приказ на резултатите од спроведената евалуација.

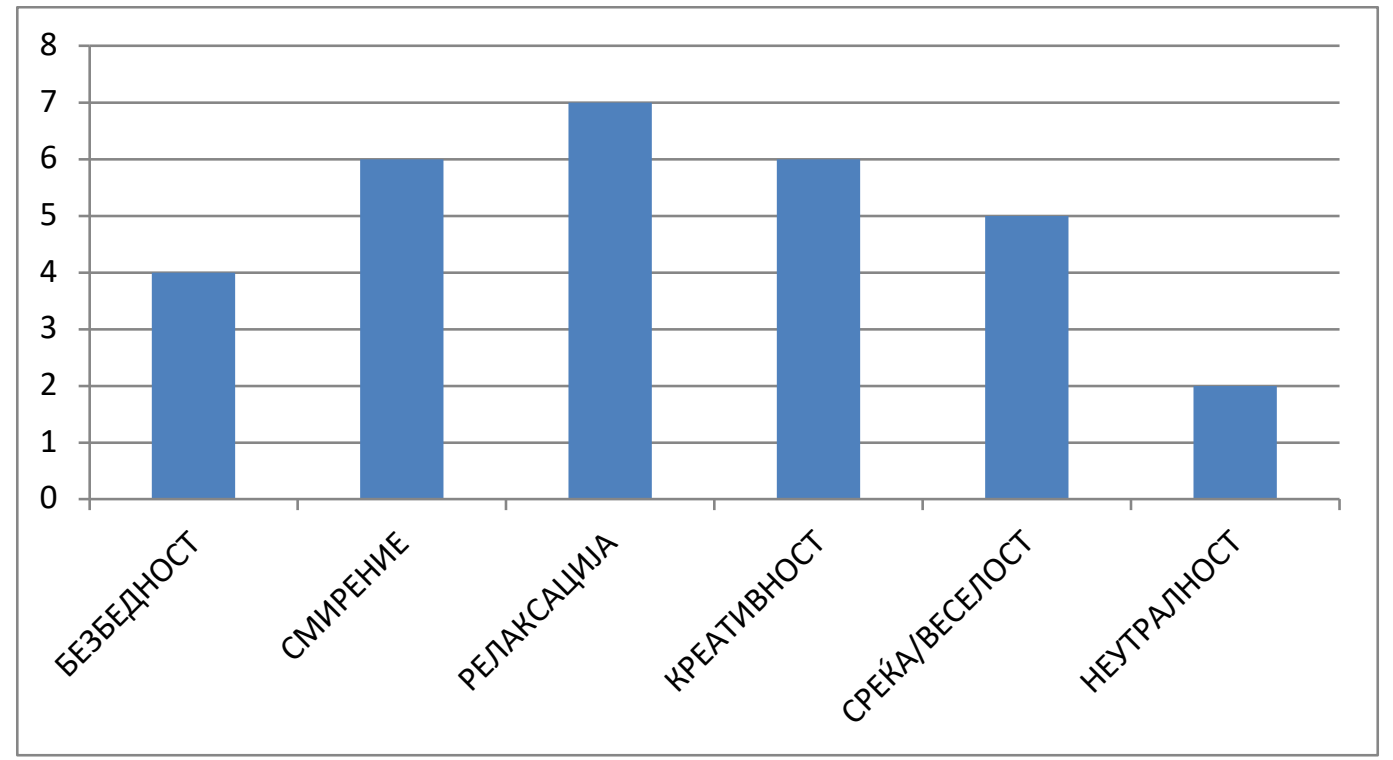

Граф. 10-1 Графички приказ на најчестите одговори од спроведената евалуација.

Од резултатите е видливо дека одговорите се позитивни, овој павиљон не појавува ниедно од негативните чувства кај испитаниците. Бројни се одговорите за чувство на безбедност, креативност, имагинација и релаксација. Исто така се појавуваат чувствата на среќа и веселост. Важно е тоа што испитаниците покрај тоа што не ги одбрале силните негативни чувства како омраза, тага, студенило или иритација, тие исто така не ги одбрале ниту чувствата на поспаност, умор и здодевност што значи дека дизајнот иако релаксира и дава чувство на сигурност, истиот не е здодевен. Единствено двајца од испитаниците се чувствувале неутрално при гледање во слики од павиљонот, а ова најверојатно се должи на природната, неутрална боја на дрвото и белите елементи во ентериерот. 


\section{1. ЗАКЛУЧОК}

Во овој магистерски труд, при направените теоретски истражувања беше согледана важноста од дизајнирањето за подобрување на менталното здравје, а откако беа спроведени сите етнографски истражувања преку детална анкета за навиките на возрасните, вработени жители на град Скопје, како и набљудувањето на нивното секојдневно однесување, беше јасно согледан недостатокот од посветено внимание токму на оваа значајна тематика.

Поради тоа, насоката во која се движеше практичното истражување, беше дизајн на простор кој ќе го подобри квалитетот на живот на граѓаните. Според направените конечни евалуации во врска со варијации на конечниот производ, реакциите на испитаниците беа позитивни во однос на целиот концепт што е индикатор дека би можело да се посвети дополнителна енергија во детални истражувања на оваа тема со цел начнатата идеја да стане реалност. Еколошкиот производ, со применета модуларност, базиран на принципите на природните системи, а пред се на принципите на позитивен дизајн, нуди многу можности за негово едноставно модифицирање и употреба во урбаната средина на град Скопје. Без разлика дали би се применувал во јавните паркови на општините или како дополнителен објект на компаниите, овој павиљон би претставувал додадена вредност и остварување на општествена одоговорност и би бил чекор напред во дизајнирањето за позитивни емоции и покренување на свеста за значењето на подобрување на менталното здравје.

Претходно поставените хипотези :

1. Доколку во град Скопје постојат соодветно опремени урбани павиљони истите би го решиле проблемот со недостаток на простор за поминување време на пауза, прекувремена работа, состаноци, социјализирање и сл. и на граѓаните би им претставувало задоволство да ги употребуваат.

2. Доколку во град Скопје постојат соодветно опремени урбани павиљони истите би влијаеле врз значително редуцирање на стресот на граѓаните во нивното секојдневие и долгорочно подобрување на нивното ментално здравје.

\section{беа потврдени.}

Направената евалуација ја покажа позитивната реакција што е индикатор дека граѓаните би сакале да употребуваат ваков простор и тоа би го зголемило нивното расположение, но за да се утврди со сигурност дека павиљонот би влијаел врз долгорочното подобрување на менталното здравје, би требало да се направи дополнително експериментално анализирање со еден примерок на ваков павиљон. Ова останува како предлог за натамошни истражувања и доработка на оваа тема. 


\section{2.КОРИСТЕНА ЛИТЕРАТУРА}

[1] S. Lyubomirsky (2008): The how of happiness: a scientific approach to getting the life you want, New York: Penguin Press

[2] P. Desmet (2011): Design for Happiness, TEDxHogeschoolUtrecht, TedXtalks, YouTube (Available: https://www.youtube.com/watch?v=jTzXSjQd8So)

[3] M. E. P. Seligman (2011): Authentic Happiness, New York: Nicholas Brealey Publishing

[4] M. Csikszentmihalyi (1975): Beyond boredom and anxiety, Jossey-Bass Publishers San Francisco Washington. London.

[5] Nakamura, M. Csikszentmihalyi (2009): The Concept of Flow, Oxford University Press

[6] P. M. A. Desmet, A. E. Pohlmeyer (2013): Positive Design: An Introduction to Design for Subjective Well-Being, IJDesign - Faculty of Industrial Design Engineering, Delft University of Technology, Delft, The Netherlands, Vol. 7, No. 3

[7] P. M. A. Desmet (2012): Faces of Product Pleasure: 25 Positive Emotions in HumanProduct Interactions, IJDesign, Faculty of Industrial Design Engineering, Delft University of Technology, Delft, The Netherlands, Vol 6., No.2

[8] Peterson, Christopher, M. E.P. Selingman (2004): Character Strengths and Virtues, Oxford: Oxford University Press

[9] United Nations, Department of Economic and Social Affairs (2014): Population Division: World urbanization prospects, New York: United Nations

[10] O. Gruebner, M. A. Rapp, M. Adli, U. Kluge, S. Galea, and A. Heinz (2017): Cities and Mental Health, Dtsch Arztebl Int

[11] S. Lyubomirsky, L. King, E. Diener (2005): The Benefits of Frequent Positive Affect: Does Happiness Lead to Success?, American Psychological Association, Psychological Bulletin, Vol.131, No.6

[12] M. B. Frisch (2013): Evidence-Based Well-Being/Positive Psychology Assessment and Intervention with Quality of Life Therapy and Coaching and the Quality of Life Inventory (QOLI), Springer Science+Business Media

[13] B. M. Staw, R. I. Sutton and L. H. Pelled (1994): Employee Positive Emotion and Favorable Outcomes at the Workplace, Organization Science, Vol. 5, No. 1

[14] J. Roe (2008): The Restorative Power of Natural and Built Environments, Heriot-Watt University School of Built Environment

[15] Alcock, White, Wheeler, Fleming, Depledge (2014): Longitudinal effects on mental health of moving to greener and less green urban areas, Environ Sci Technol.

[16] C. W. Thompson, P. Aspinall, J. Roe (2014): Access to Green Space in Disadvantaged Urban Communities: Evidence of Salutogenic Effects Based on Biomarker and Self-report Measures of Wellbeing, Procedia - Social and Behavioral Sciences, Vol.153 
[17] J. Roe, P. Aspinall (2011): The restorative benefits of walking in urban and rural settings in adults with good and poor mental health, Health Place

[18] J. Walker (2016): How to use biophilic urban acupuncture to promote good mental health, Sanity and Urbanity: a UD/MH blog

[19] C. Collins (2016): Urban green spaces and health - a review of evidence, World Health Organisation report

[20] R. Corcoran, G. Marshall (2016): Planning for Wellbeing, The Prosocial Place Programme: Institute of Psychology Health and Society and Heseltine Institute of Public Policy \& Practice, University of Liverpool, UK

[21] M. D. Greicius, B. H. Flores, V. Menon, G. H. Glover, H. B. Solvason, H. Kenna, A. L. Reiss, A. F. Schatzberg (2007): Resting-state functional connectivity in major depression: abnormally increased contributions from subgenual cingulate cortex and thalamus, Biol Psychiatry

[22] Queensland Government (2007): Crime Prevention through Environmental Design guidelines for Queensland, Part A: Essential features of safer places, The State of Queensland

[23] T. Litman (2018): Urban Sanity Understanding Urban Mental Health Impacts and How to Create Saner, Happier Cities, Victoria Transport Policy Institute

[24] D. A. Norman (2004): Emotional Design, Basic Books, A Member of the Perseus Books Group

[25] С. Р. Јовановска (2013): Однесување на потрошувачите, Економски факултет Скопје

[26] J. A. Dakheel, K. T. Aoul (2017): Building Applications, Opportunities and Challenges of Active Shading Systems: A State-Of-The-Art Review, Architectural Engineering Department, United Arab Emirates University

[27] A. S. Odom, S. S. Sholtz (2000): The Reds, Whites, and Blues of Emotion: Examining Color Hue Effects on Mood Tones, Missouri Western State University Department of Psychology

[28] L. L. Norton (2006): What Color is Your Mood, Missouri Western State University Department of Psychology

[29] C. O. Lawler, E. E. Lawler (1965): Color Mood Associations in Young Children, The Journal of Genetic Psychology 107

[30] R. Mehta, R. J. Zhu (2009): Blue or Red? Exploring the Effect of Color on Cognitive Task Performances, Science Vol.323, Issue 5918

[31] J. T. McConville, Antropoloy Research Project 
КОРИСТЕНИ МАТЕРИЈАЛИ ОД ВЕБ ЛИНКОВИ:

[32] http://www.happyplanetindex.org/about/

[33] http://www.urbandesignmentalhealth.com/how-the-city-affects-mental-health.html

[34] https://www.urbandesignmentalhealth.com/how-urban-design-can-impact-mentalhealth.html

[35] https://www.hsph.harvard.edu/obesity-prevention-source/obesity-causes/physicalactivity-environment/

[36] http://www.archilovers.com/projects/149903/the-duplantier-volunteerpavilion.html\#images

[37] https://inhabitat.com/tiny-timber-meditation-pavilion-in-italy-reconnects-people-tonature/

[38] https://inhabitat.com/sharon-fieldhouse-is-a-naturally-cooled-glass-pavilion-in-virginia/

[39] https://inhabitat.com/omas-mpavilion-2017-with-a-floating-roof-opens-today-inmelbourne/

[40] https://inhabitat.com/diebedo-francis-keres-rainwater-harvesting-2017-serpentinepavilion-unveiled-in-london-today/

[41] https://inhabitat.com/a-tremendous-translucent-forest-pops-up-in-a-french-courtyard/

[42] http://www.contemporist.com/nets-for-lying-in-become-a-unique-attraction-at-thiswaterfront-walkway/

[43] https://dirt.asla.org/2012/08/14/a-natural-wi-fi-station-in-paris/

[44]

https://mk.wikipedia.org/wiki/\%D0\%93\%D1\%80\%D0\%B0\%D0\%B4\%D1\%81\%D0\%BA\%D0\%B

8_\%D0\%BF\%D0\%B0\%D1\%80\%D0\%BA_(\%D0\%A1\%D0\%BA\%D0\%BE\%D0\%BF\%D1\%98\%D0\%B

5)

[45] http://arhiva.netpress.com.mk/mk/vest.asp?id=104840\&kategorija=1

[46] https://www.fix.com/blog/benefits-of-being-near-water/

[47] https://psychcentral.com/blog/waters-psychological-benefits/

[48] http://www.health.com/stress/why-nature-sounds-are-relaxing

[49] http://mkd-news.com/foto-moderniot-zelen-park-vo-gorno-lisiche-od-denes-voupotreba/

[50] http://skopjeinfo.mk/mesto-kako-od-bajka-nov-park-vo-gorno-lisiche-foto

[51] https://skopje24.mk/nov-moderen-park-vo-skopje-urbano-katce-vo-kozle/

[52] https://www.behance.net/gallery/9204847/Public-Square-Karposh-3 
[53] https://www.arch2o.com/dynamic-facades-the-story/

[54] https://www.archdaily.com/162101/ad-classics-institut-du-monde-arabe-jean-nouvel

[55] https://www.archdaily.com/89270/kiefer-technic-showroom-ernst-giselbrecht-partner

[56] https://www.archdaily.com/270592/al-bahar-towers-responsive-facade-aedas

[57] https://www.archdaily.com/590576/sdu-campus-kolding-henning-larsen-architects

[58] http://www.apc.com/salestools/SNIS-66ZTJB/SNIS-66ZTJB_R1_EN.pdf

[59]

http://www.bio.miami.edu/tom/courses/bil160/bil160goods/plantform/13_plantform.html [60] http://www.bregalnica-ncp.mk/wp-content/uploads/2016/07/Final-Solar-system-1.pdf

[61] https://www.rainforest-alliance.org/species/bromeliad

[62] http://www.nhptv.org/natureworks/nwep8e.htm

[63] http://bhort.bh.cornell.edu/conservatory/cpage6.html

[64] http://awoltrends.com/2015/10/origami/ 


\section{ПРИЛОГ А}


1. Пол:
M 26
Ж 24

2. Возраст:

$\begin{array}{ll}20-25 & 5 \\ 25-30 & 10 \\ 30-40 & 11 \\ 40-50 & 12 \\ 50-60 & 12\end{array}$

3. Колку часа дневно поминувате на работното место?

6 часа или помалку 0

8 часа 42

10 часа 8

12 часа или повеќе 0

4. Колку често работите прекувремено?

Ретко 5

Неколку пати во месецот 17

Еднаш - два пати неделно 15

Три - четири пати неделно 9

Скоро секој ден 4

5. Во просек, во текот на работниот ден, колку вкупно време поминувате на пауза?

Немам пауза 0

5 - 10 минути 6

10 - 15 минути 9

15 - 30 минути 21

Повеќе од 30 минути 14

6. Каков е просторот каде ја поминувате паузата?

Кујна / бифе внатре во работниот објект 19

Простор предвиден за одмор внатре во работниот објект 6

Простор предвиден за одмор надвор од работниот објект 0

Простор во или надвор од работниот објект кој не е наменет ниту соодветно уреден за поминување на паузата во него 19

Надвор од работниот објект - во кафуле, ресторан и сл. 1

Надвор од работниот објект - во близок парк, клупи на отворено и сл. 5

Друго: 


\section{7. За што ја користите паузата? (Може да се одберат повеќе одговори)}

Немам пауза 0

За работа надвор од работното место, истражување, состаноци и сл. 6

За доручек / ручек 37

За пиење кафе 27

За дружење со колегите 17

За завршување на кратки приватни обврски 9

За сурфање на интернет 8

Друго:

8. Колку сте задоволни од просторот каде ги минувате слободните минути во текот на денот?

Воопшто не сум задоволен/на - просторот е ужасен 19

Малку сум задоволен/на - генерално не ми се допаѓa, но барем има каде да ги

поминам слободните минути наместо на биро пред компјутер 21

Средно сум задоволен/на - генерално не е лош, но може да се подобри, има работи што недостасуваат 7

Многу сум задоволен/на - просторот е одличен за намената, ги полнам

батериите додека сум на пауза и продолжувам со продуктивна работа 3

9. Колку изгледот на просторот во кој работите и просторот каде ја минувате паузата влијае врз Вашето расположение и продуктивност?

Воопшто не влијае 5

Слабо влијае 3

Средно влијае 18

Многу влијае 24

10. Колку често се чувствувате преплавени од работа и обврски и под стрес во текот на денот?
Ретко 5
Понекогаш 15
Многу често 24
Постојано 6

11. Колку денови во неделата се чувствувате недоволно одморени и недоволно продуктивни?

03

1 - 228

$3-414$

5 или повеќе 5 
12. Се чувствувате најжелни за работа и најпродуктивни кога...? (Може да се одберат повеќе одговори)

Сте добро одморени 36

Работниот простор е добро уреден и организиран 19

По пиењето на кафе 18

По ручекот / ужината 17

Кога слушате музика 9

Кога постои добра дневна организација и комуникација со колегите и претпоставените 32

Кога имате време да креирате листа со обврски и ја следите истата 7

Кога имате време за една голема пауза во текот на денот 14

Кога правите краки, но почести паузи во текот на денот 10

Друго:

13. Што мислите дека ја стимулира Вашата креативност? (Може да се изберат повеќе одговори)

\author{
Добар сон 35 \\ Одмор во текот на денот 36 \\ Престој на отворено 28 \\ Медитација 8 \\ Музика 10 \\ Разговор (брејнсторминг) 19 \\ Друго:
}

14. Дали сметате дека би биле посреќни, попродуктивни и покреативни во текот на денот доколку имате неколку минути за пауза сами или со колегите кои ќе ги поминете на место соодветно уредено токму за таа намена?

Да 41

He 3

Не знам 6

15. Дали дополнителната работа би Ви била полесна доколку ја вршите на релаксирано место надвор од стандардниот работен објект?
Да 43
He 5
Не знам 2

16. Во просек, колку време во текот на денот посветувате на себе?

Немам време за себе 1

Можам да одвојам само 15 - 30 минути 17

Имам околу 1 - 2 часа време за себе 23

Имам повеќе од 2 часа време за себе 9 
17. Во слободното време во текот на денот најчесто...? (Може да се изберат повеќе одговори)

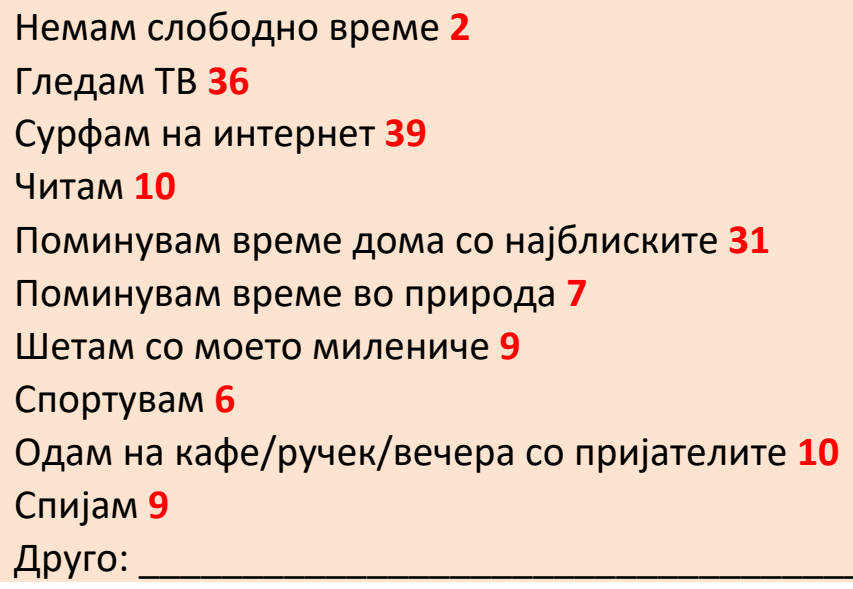

18. Дали сметате дека начинот на живот во овој главен град (гужвата, градбите, сообраќајниот метеж, навиките на граѓаните и сл.) влијае врз зголемување на нивото на стрес во Вашето секојдневие?

Уживам во животот во Скопје 0

Начинот на живот во Скопје не влијае стресно врз мене, навикнат/а сум на сите позитивни и негативни аспекти 17

Начинот на живот во Скопје влијае врз зголемување на секојдневниот стрес 33

19. Дали сметате дека во Скопје постојат доволно урбани катчиња (не земајќи ги во предвид кафулињата и рестораните) за поминување на слободно време?

Да 3

He 37

Не знам 10

20. Дали доколку постои соодветно урбано катче во близина на Вашиот дом би поминувале време во него - читајќи, работејќи, одмарајќи од работните и семејните обврски?

Да 39

He 3

Не знам 8

\section{* ДОКОЛКУ ОДГОВОРИВТЕ ПОТВРДНО НА ПРЕТХОДНОТО ПРАШАҢЕ ->}

21. Што би сакале да биде вклучено во едно такво урбано катче за да ги задоволи Вашите потреби и очекувања (може да се изберат повеќе одговори)?

Да биде во природа 18

Да биде на мирно место 27

Да има место за приклучување електрични уреди 21

Да има пристап до бесплатно wi-fi 27

Да има можност за приватност 22

Во негова близина да има продажба на храна/пијалоци 14

Да биде лесно за пристап 30

Да има паркинг во близина 17

Да има велосипедски паркинг 10

Да има простор за миленици во близина 7

Да има игралиште за деца во близина 3

Друго: 
ПРИЛОГ Б 


\section{АНКЕТА ЗА НАЈИЗРАЗЕНИТЕ ЕМОЦИИ АСОЦИРАНИ СО ДИЗАЈНИРАНИОТ ПАВИЉОН}

Маркирајте ја најизразената емоција која се јавува кај Вас при разгледување на сликите од павиљонот прикажани подолу.

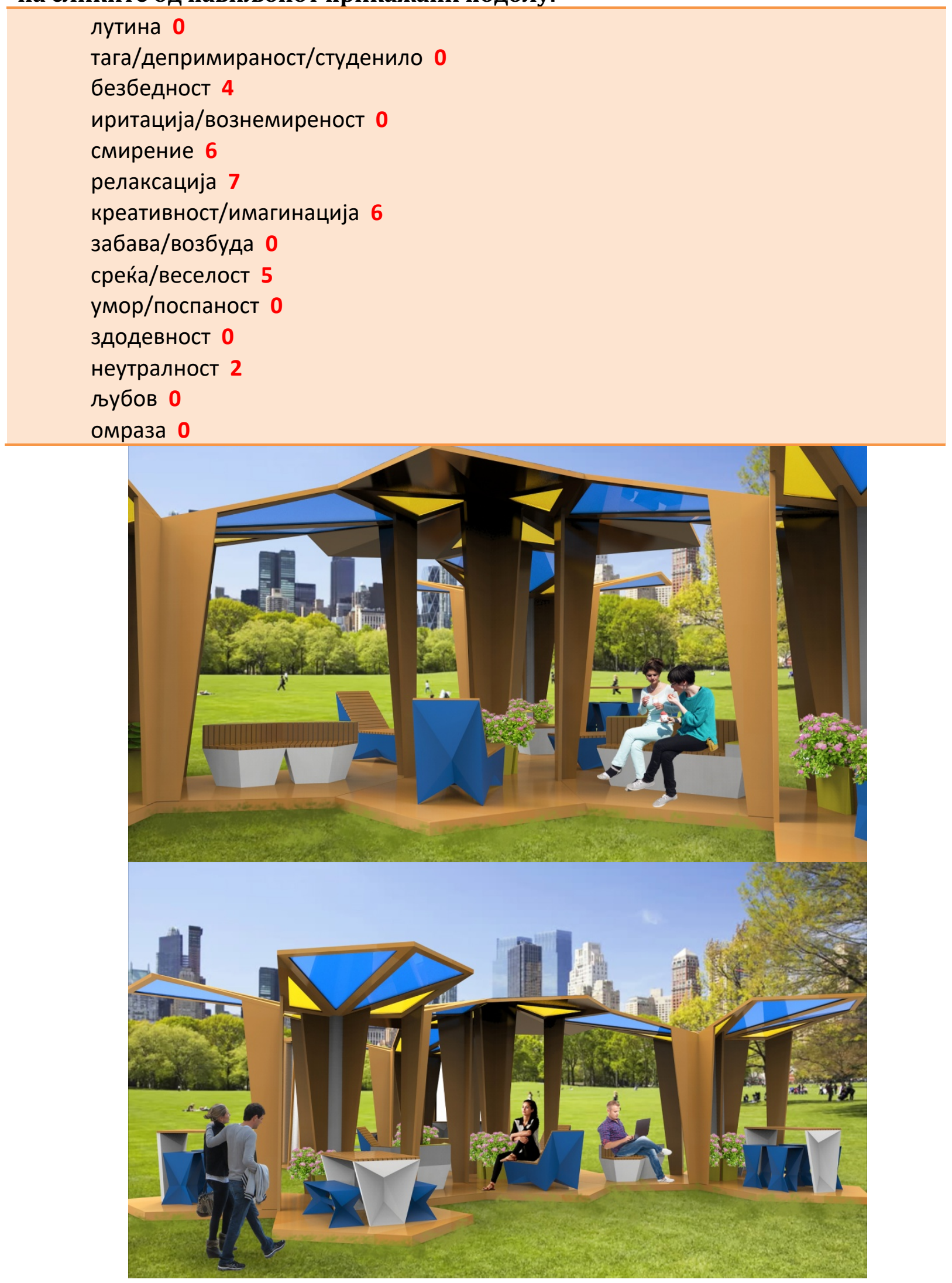

